CENTRO UNIVERSITÁRIO FEI

MARCOS TAVARES BARDERI

APLICAÇÃO DOS PRINCÍPIOS DA ECONOMIA CIRCULAR EM UMA INDÚSTRIA DE VEÍCULOS COMERCIAIS 


\section{APLICAÇÃO DOS PRINCÍPIOS DA ECONOMIA CIRCULAR EM UMA INDÚSTRIA DE VEÍCULOS COMERCIAIS}

Projeto de dissertação de Mestrado apresentada ao Centro Universitário da FEI, como parte dos requisitos necessários para obtenção do título de Mestre em Administração de Empresas, orientado pela Profa. Dra. Maria Tereza Saraiva de Souza. 
Tavares Barderi, Marcos.

Aplicação dos principios da economia circular em uma indústria de veiculos comerciais. / Marcos Tavares Barderi. São Paulo, 2017.

$137 \mathrm{p}$ : : il.

Dissertação - Centro Universitário FEI.

Orientador: Prof. Dr. Maria Tereza Saraiva de Souza.

1. Economia circular. 2. sustentabilidade. 3. veiculos comerciais. I. Saraiva de Souza, Maria Tereza, orient. II. Titulo.

Elaborada pelo sistema de geração automática de ficha catalográfica da FEI com os dados fornecidos pelo(a) autor(a). 
centro

universitário

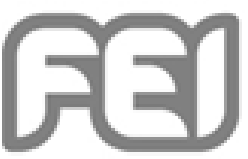

APRESENTAÇÃo DE DISSERTAÇÃo

ATA DA BANCA JULGADORA

Programa de Pós-Graduação Stricto Sensu em Administração

MESTRADO PPGA-10

Aluno: Marcos Tavares Barderi

Matrícula: $321509-2$

Título do Trabalho: Aplicação dos Princípios da Economia Circular em uma Indústria de Veículos Comerciais.

Area de Concentração: Gestão da Inovação

Orientador: Profa, Dra, Maria Tereza Saraiva de Souza

Data da realização da defesa: $31 / 10 / 17$.

Avaliação da Banca Examinadora:

São Paulo, $31 / 10 / 17$.

ORIGINAL ASSINADA

MEMBROS DA BANCA EXAMINADORA

Prof?. Dra. Maria Tereza Saraiva de Souza Ass.:

Prof. Dr. Jacques Demajorovic

Assi,

Prof. Dr. Aldo Roberto Ometta

Assi,

A Banca Julgadora acima-assinada atribuiu ao aluno o seguinte resultado:

APROVADO $\square \quad$ REPROVADO $\square$

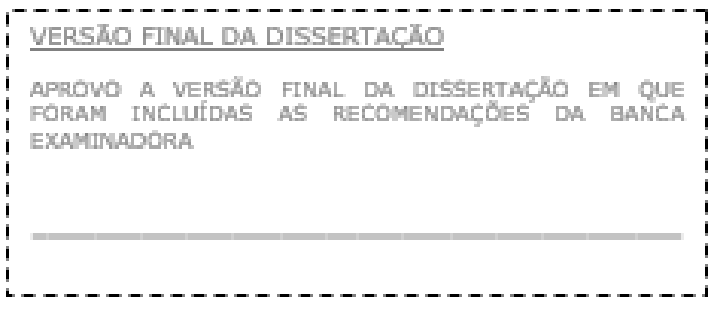

Aprovaçăo do Coordenador do Programa de Pós-graduaçắo

Prof. Dr. Henrique Machado Barros 
Dedico esta dissertação à minha família, que sempre me apoiou e incentivou. 


\section{AGRADECIMENTOS}

A todos que contribuíram para a realização deste trabalho, direta ou indiretamente, principalmente aos professores e colegas do PPGA/FEI.

À orientadora, Profa. Dra. Maria Tereza Saraiva de Souza, pela paciência, orientação e ensinamentos.

Aos membros da banca de qualificação, professores Dr. Jacques Demajorovic e Dra. Carmen Augusta Varela, pelas recomendações que contribuíram para a adequação do estudo para a defesa final.

Aos colaboradores da companhia, que disponibilizaram seu tempo para as entrevistas e para o compartilhamento de informações.

À minha família, por todo o apoio recebido. 


\section{RESUMO}

A escassez de reservas minerais, somada à grande geração de resíduos, apresenta um novo desafio de conciliar o crescimento econômico com a conservação ambiental. O tradicional perfil de desenvolvimento pratica uma economia linear, extraindo recursos, transformando-os, e os descartando após seu uso. O desenvolvimento de novos produtos, que consome novas matérias-primas e promove, no máximo, a reciclagem no fim da vida, não incentiva uma eficiência produtiva, tampouco uma nova forma de consumo de bens. Um dos setores industriais que possui grande importância na economia é o setor automotivo que, apesar de gerar riqueza e emprego, pratica tradicionalmente uma economia linear, consumindo recursos naturais e gerando grande quantidade de resíduos. Diante desse contexto, a Economia Circular, que é uma oposição à economia linear de extração, produção e descarte, surge como alternativa para a promoção de novos modelos de negócios e formas de consumo que auxiliam a conservação ambiental, dissociando o desenvolvimento da economia do aumento do consumo de recursos naturais, pela circularidade dos materiais. Por meio de um estudo de caso com diferentes unidades de análise, o objetivo do presente trabalho é analisar a aplicação dos princípios da Economia Circular na cadeia de valor do caminhão, em uma indústria de veículos comerciais. Para isso, foi estudado o conceito de Economia Circular, identificados os elementos desse novo modelo econômico na empresa e analisado o nível de implementação de seus princípios e de sua estrutura. As fontes de evidência utilizadas foram entrevistas semiestruturadas, observação direta, pesquisa documental e registros em arquivo. Os resultados da pesquisa evidenciaram alguns elementos da Economia Circular, que trouxeram benefícios ambientais, envolvendo: a redução de consumo de recursos naturais para a confecção de novas peças e componentes, a aplicação de logística reversa de peças usadas para a aquisição de peças remanufaturadas, o incentivo ao uso de oficinas de concessionárias, que possuem controle operacional e ambiental, e a redução do descarte de resíduos inerentes às atividades de pósvenda da cadeia de valor do caminhão. No entanto, para se desenvolver uma estrutura completa de Economia Circular, é preciso considerar o investimento em todos os loops dos materiais e, principalmente, desenvolver uma forma consciente de consumo de bens, compartilhando a responsabilidade sobre os impactos em toda a cadeia.

Palavras-chave: Economia Circular. Sustentabilidade. Veículos Comerciais. 


\begin{abstract}
The scarcity of mineral reserves combined with the large generation of waste means a new challenge of reconciling economic growth with environmental conservation. The traditional model of development practices a linear economy, extracting, transforming and discarding resources after their use. The development of new products, which consumes new raw materials and only promotes recycling at the end of life, does not encourage a productive efficiency or a new form of consumption of goods. One of the industrial sectors that has great importance in the economy is the vehicles industry, which even generating wealth and employment, traditionally practices a linear economy, consuming natural resources and generating large amount of waste. In this context, the Circular Economy, that is an opposition to the linear economy of extraction, production and disposal, emerges as an alternative for the promotion of new business models and forms of consumption that help stabilize growth and environmental conservation, dissociating the development of the economy with increasing consumption of natural resources, using the circularity of the materials. Through a case study with different units of analysis, the objective of this study is to analyze the application of the Circular Economy principles in the truck value chain of the commercial vehicles industry. For this, it was studied the concept of Circular Economy, identified the elements of this new economic model in the company and analyzed the level of implementation of its principles and structure. The sources of evidence used were semi-structured interviews, direct observation, documents research and files records. The results of the research evidenced some elements of the Circular Economy, which generated environmental benefits involving: the reduction of natural resources consumption for the production of new parts and components, the implementation of reverse logistics of used parts for the acquisition of remanufactured products, the incentive to use dealers workshops, that has environmental and operational control, and the reduction of waste from after-sales activities of the truck value chain. However, in order to develop a complete Circular Economy structure, is necessary to consider investing in all material loops and, in particular, developing a conscious form of consumption of goods, sharing responsibility for impacts throughout the chain.
\end{abstract}

Keywords: Circular Economy. Sustainability. Commercial Vehicles. 


\section{LISTA DE FIGURAS}

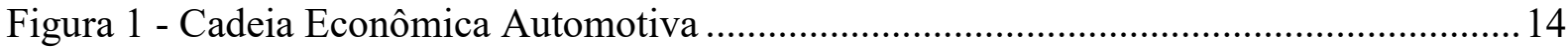

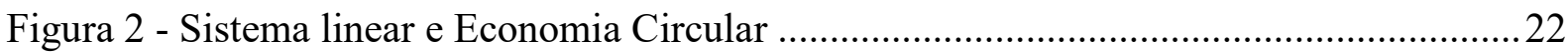

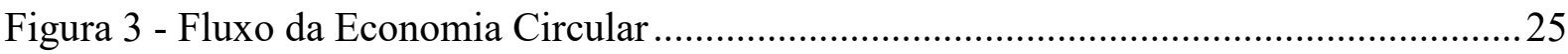

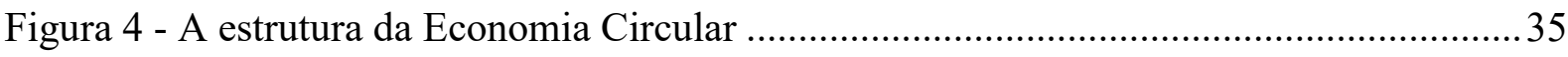

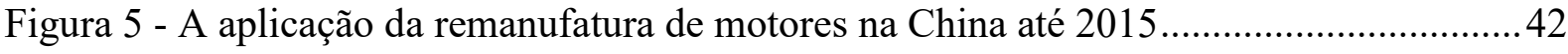

Figura 6 - Fluxo do ciclo de vida do motor e da remanufatura ............................................... 43

Figura 7 - Exemplo de reciclagem química, mecânica e energética para o plástico ................ 45

Figura 8 - Fluxo de destinação de um automóvei em final de vida na Austrália ..................... 48

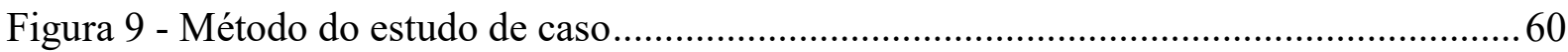

Figura 10 - Fontes de evidência para a coleta de dados no estudo de caso .............................. 64

Figura 11 - Ilustração do motor e dos sistemas arrefecimento, combustível e escapamento ... 72

Figura 12 - Ilustração do sistema de pedal e embreagem, caixa de câmbio e transmissão .......72

Figura 13 - Ilustração dos eixos, sistema de freio, cubo e roda, suspensão e direção ...............73

Figura 14 - Ilustração dos sistemas elétricos, da cabine e da carroceria ................................. 73

Figura 15 - Comparativo da emissão gases de efeito estufa Diesel de Cana e Diesel fóssil.... 76

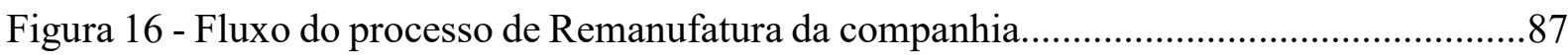

Figura 17 - Locais do motor que recebem intervenção da Remanufatura..................................89

Figura 18 - Locais do câmbio que recebem intervenção da Remanufatura...............................90

Figura 19 - Fluxo de desmontagem e reciclagem de um veículo em final de uso nos CRVs.......91

Figura 20 - As unidades de análise na cadeia da companhia..................................................94

Figura 21 - As unidades de análise na estrutura da Economia Circular.................................97

Figura 22 - A hierarquia do ciclo técnico da EC na cadeia do caminhão.................................104

Figura 23 - Proposta de novos loops na estrutura da Economia Circular................................106 


\section{LISTA DE QUADROS}

Quadro 1 - Os níveis de implementação da Economia Circular............................................... 17

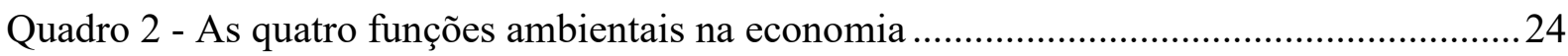

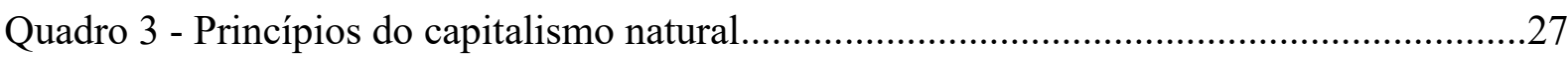

Quadro 4 - Exemplos de contribuição das áreas de conhecimento na Economia Circular ......28

Quadro 5 - Descrições dos fundamentos da Economia Circular .............................................. 33

Quadro 6 - Quadro síntese do princípio 1 da Economia Circular ...........................................36

Quadro 7 - Tratamentos dos materiais técnicos conforme hierarquia da Economia Circular.. 38

Quadro 8 - Resultados encontrados sobre a remanufatura de componentes mecânicos.............43

Quadro 9 - Quadro síntese do princípio 2 da Economia Circular .............................................. 48

Quadro 10 - Quadro síntese do princípio 3 da Economia Circular ..........................................50

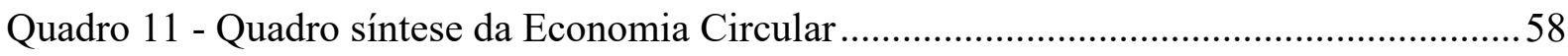

Quadro 12 - Plantas produtivas da companhia no escopo da Economia Circular....................61

Quadro 13 - Adequação dos elementos da Economia Circular ao estudo ................................63

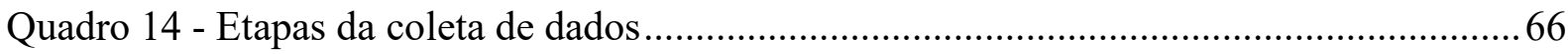

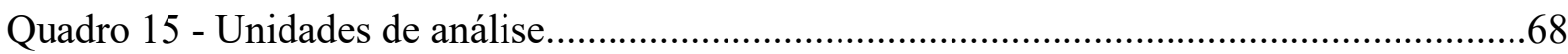

Quadro 16 - Requisitos ambientais da companhia para as concessionárias ............................69

Quadro 17 - Conjuntos e principais peças de um caminhão.................................................... 70

Quadro 18 - Setores do DfE da companhia na Alemanha......................................................74

Quadro 19 - Comparação das emissões do PROCONVE P5 e do PROCONVE P7 .................76

Quadro 20 - Escopo dos serviços do Programa ServicePlus.....................................................81

Quadro 21 - Principais aspectos ambientais da Remanufatura e seus respectivos controles

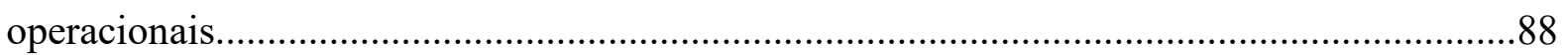

Quadro 22 - Evidências encontradas e suas fontes...............................................................98 


\section{SUMÁRIO}

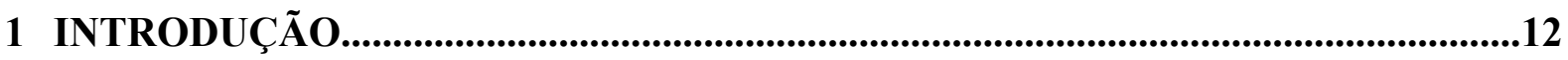

1.1 JUSTIFICATIVA E QUESTÃO DE PESQUISA..........................................................17

1.2 OBJETIVO GERAL E OBJETIVOS ESPECÍFICOS.....................................................19

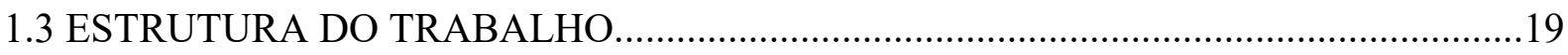

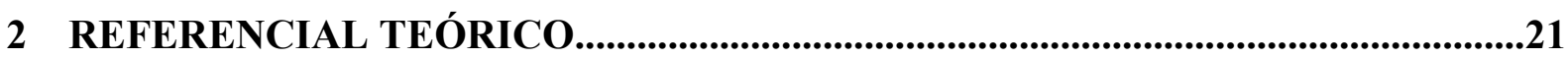

2.1 DO MODELO LINEAR PARA O MODELO CIRCULAR.................................................

2.2 A ESTRUTURA E OS PRINCÍPIOS DA ECONOMIA CIRCULAR..................................29

2.2.1 Princípio 1: a gestão de fluxos renováveis e de estoques....................................................35

2.2.2 Princípio 2: os ciclos biológico e técnico...........................................................................36

2.2.2.1 O ciclo biológico da Economia Circular............................................................................37

2.2.2.2 O ciclo técnico da Economia Circular..............................................................................37

2.2.3 Princípio 3: minimização de perdas e externalidades negativas....................................49

2.3 APLICAÇÃO DO MODELO DE ECONOMIA CIRCULAR.............................................50

2.4 AS CRÍTICAS AO MODELO DE ECONOMIA CIRCULAR.............................................56

3 MÉTODO DE PESQUISA.....................................................................................59

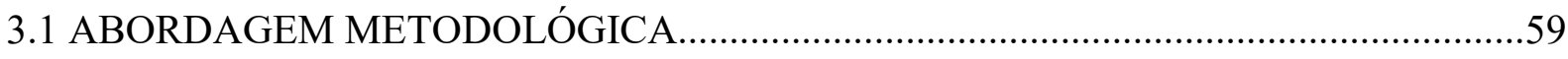

3.2 ESTUDO ÚNICO DE CASO COM DIFERENTES UNIDADES DE ANÁLISE...............60

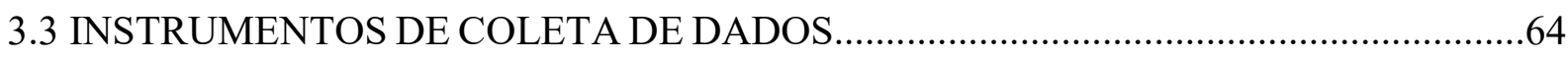

3.4 FORMA DE TRATAMENTO E ANÁLISE DE DADOS..................................................67

4 RESULTADOS DA PESQUISA..........................................................................................68

4.1 A ESTRUTURA DE UM CAMINHÃO...................................................................

4.2 UNIDADE DE ANÁLISE DESENVOLVIMENTO DE CAMINHÕES..............................74

4.3 UNIDADE DE ANÁLISE LOJA VIRTUAL DE PEÇAS....................................................79

4.4 UNIDADE DE ANÁLISE PROGRAMA SERVICEPLUS...............................................8

4.5 UNIDADE DE ANÁLISE PROGRAMA SERVICE24H.................................................82

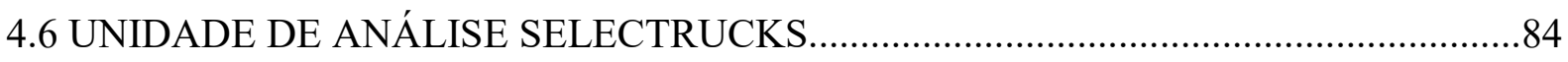

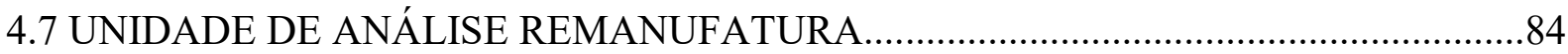

4.7.1 Remanufatura de Motores......................................................................................88

4.7.2 Remanufatura de Câmbios......................................................................................................89

4.8 PEÇAS E COMPONENTES EM FINAL DE VIDA.........................................................91

5 ANÁLISE E DISCUSSÃO DOS RESULTADOS..........................................................94 
5.1 AS UNIDADES DE ANÁliSE NA ESTRUTURA DA ECONOMIA CIRCULAR.

5.2 OS ELEMENTOS DA ECONOMIA CIRCULAR NAS UNIDADES DE ANÁLISE....97

5.2.1 Evidências dos elementos da subcategoria gestão de fluxo de renováveis e de estoques.....................................................................................................................................99

5.2.2 Evidências dos elementos da subcategoria ciclo técnico............................................101

5.2.3 Evidências dos elementos da subcategoria externalidades........................................103

5.2.4 A hierarquia do ciclo técnico da Economia Circular na cadeia do caminhão...........104

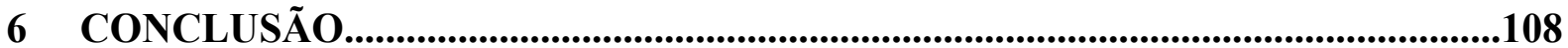

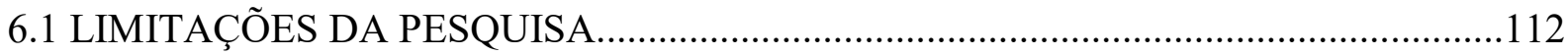

6.2 RECOMENDAÇÕES PARA FUTURAS PESQUISAS............................................112

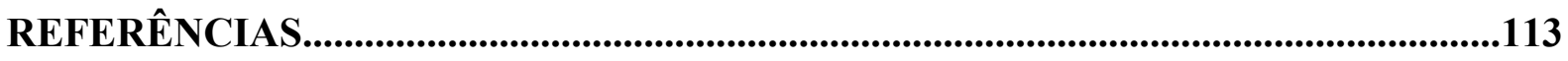

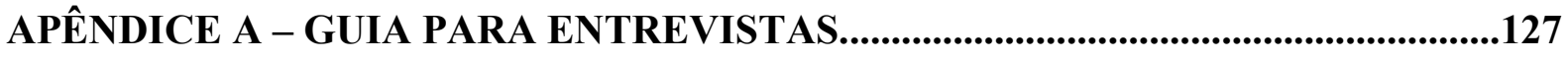

APÊNDICE B - INDICADORES E QUESTÕES DA ENTREVISTA

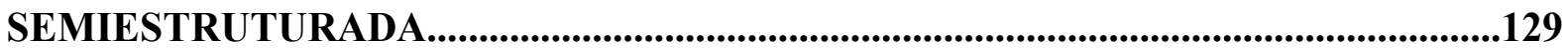

APÊNDICE C - PROTOCOLO DE OBSERVAÇÃO..................................................135 


\section{INTRODUÇÃO}

No decorrer da história, o ser humano progrediu para sanar suas necessidades, transformando recursos naturais em bens e serviços e buscando melhorar a economia e o bemestar social (O'SULLIVAN; SHEFFRIN, 2003). Entretanto, o processo de desenvolvimento da humanidade, apesar de proporcionar geração de empregos e desenvolvimento social, trouxe graves impactos negativos, considerando o inconsequente uso de recursos naturais e a elevada geração de resíduos (GILJUM et al., 2009). Em 2010, 65 bilhões de toneladas de matéria-prima foram consumidas no mundo, e as projeções indicam que, até 2020, esta quantidade será de 82 bilhões de toneladas por ano (EMF, 2012). Em relação aos resíduos municipais, no mundo, aproximadamente 1,3 bilhão de toneladas foram geradas em 2012, devendo aumentar para 2,2 bilhões de toneladas até 2025. Esses dados representam um aumento significativo de geração per capita de 1,2 para 1,42 kg por dia (HOORNWEG; BHADA-TATA, 2012).

Outro aspecto relevante a ser destacado é a desigualdade de consumo, em termos mundiais. Um americano, em média, extrai tantos recursos quanto 35 nativos indianos e consome 53 vezes mais bens e serviços do que uma pessoa na China (SCHEER; MOSS, 2012). Em 1972, o relatório "Limites do Crescimento" apresentou um cenário com previsão de esgotamento dos recursos naturais decorrente do modelo de desenvolvimento tradicional (MEADOWS; MEADOWS; RANDERS, 1972). A abundância de bens de consumo produzidos pelo sistema industrial, que era considerada um símbolo de sucesso da economia, passou a ser vista de forma negativa. Além do impacto ambiental causado pela extração inconsequente de recursos e descarte de resíduos, o consumo passou a trazer conflitos entre classes, provenientes da participação desigual na estrutura produtiva, na distribuição e na apropriação de bens (BRASIL, 2005).

Em razão das pressões dos órgãos governamentais, por meio de leis, ou até do próprio mercado, por meio de certificações (DARNALL; JOLLEY; HANDFIELD, 2008), as companhias estão expandindo a gestão ambiental para toda a cadeia do negócio, não limitando práticas conscientes às instalações onde ocorrem as operações produtivas. A minimização de impactos ambientais pode ser atingida por meio da integração de práticas em diferentes áreas (GROSSMANN, 2004). Por exemplo, uma área de desenvolvimento pode projetar um produto com menor peso e que utiliza menos materiais, reduzindo o consumo de recursos naturais e otimizando transportes logísticos no quesito de consumo de combustível, uma vez que o material a ser transportado será mais leve. 
Questionamentos têm surgido em relação ao modelo econômico tradicional, em que os recursos naturais são extraídos, processados, consumidos e descartados como resíduos, sem considerar as limitações de recursos e do poder de assimilação do meio ambiente sobre os rejeitos (ANDERSEN, 2007). Esse modelo tradicional de economia linear possui fatores que colaboram para o surgimento de prejuízos para a sociedade, tais como: perdas econômicas e desperdício estrutural, pois nosso atual modelo econômico gera valor com desperdício; risco de oferta, já que diversas regiões no globo terrestre possuem poucos depósitos próprios de recursos naturais não renováveis, havendo necessidade de importação, como é o caso do petróleo em diversos locais; degradação dos sistemas naturais, que tem como desafio a criação de riqueza global em longo prazo sem trazer consequências ambientais negativas; e, por fim, tendências regulatórias, já que, principalmente nos últimos anos, órgãos reguladores estão envidando esforços para o estabelecimento de requisitos que buscam reduzir e estabelecer custos para as externalidades negativas, tendo como exemplo a precificação do carbono em diversas regiões do mundo (EMF, 2015). Além dos impactos ambientais e sociais negativos, o aumento dos custos também é uma preocupação, já que a escassez dos recursos naturais exigirá novos modelos operacionais, o que demandará tempo e investimentos (GUIDAT et al., 2014). Nesse contexto, a Economia Circular surge como uma alternativa ao modelo econômico tradicional, promovendo novos modelos de negócios e formas de consumo que auxiliam na estabilização do crescimento e na conservação ambiental (EMF, 2015).

Um dos segmentos industriais que mais cresceu no século passado foi o setor automobilístico, que movimentou no mundo cerca de US\$ 2,5 trilhões em 2005 e, se fosse um país, possuiria o sexto maior PIB mundial naquela época (GABRIEL et al., 2011). Além do aspecto financeiro, a indústria automotiva possui um importante papel no desenvolvimento de diversos outros setores, sendo que, em 2008, $50 \%$ do total de borracha, $25 \%$ do total de vidro e $15 \%$ do total de aço produzidos no mundo se destinavam ao segmento, mediante o trabalho direto de mais de 8 milhões de funcionários. Em 2007, a venda de automóveis nos EUA, por exemplo, ultrapassou o volume de 16 bilhões de unidades. No mesmo ano, o mercado brasileiro já atingia mais de 2 bilhões de automóveis vendidos (CASOTTI; GOLDENSTEIN, 2008). No entanto, a indústria automotiva se tornou uma das mais impactantes para meio ambiente. $\mathrm{O}$ automóvel é um agente emissor de gases de efeito estufa, é responsável por engarrafamentos nos grandes centros urbanos, o que prejudica a mobilidade, e a indústria não tem muito controle sobre o descarte de peças e componentes (VAZ; LEZANA; MALDONADO, 2017). Em razão do aumento do volume de veículos, existe a necessidade de desenvolver iniciativas de gestão de resíduos por parte do governo e das indústrias, não apenas em termos de processos de 
produção, mas também para a destinação de resíduos de veículos em final de vida. Atualmente, mais de $75 \%$ do peso de um veículo é reciclado, trazendo benefícios não apenas ambientais, mas também econômicos, pois ajuda a resolver a falta de oferta de determinados materiais durante processos de fabricação (SHARMA et al., 2016).

No Brasil, a indústria automotiva iniciou sua história em 1900, com a chegada dos primeiros veículos importados, e teve sua primeira linha de montagem 19 anos depois, com a vinda da Ford. Entre 1925 e 1927, chegaram ao país a General Motors e a Fiat, respectivamente. Em 1952, o setor já representava pouco mais de 15\% das importações (BARROS; PEDRO, 2011). Com um importante papel no Brasil, a indústria de veículos já possuía em 2010 uma capacidade produtiva de 4,3 milhões de unidades e representava $25 \%$ das exportações de manufaturados (ANFAVEA; CNI, 2012). Em 2015, a frota em circulação atingiu uma quantidade maior do que 40 milhões de unidades (ANFAVEA, 2015; FENABRAVE, 2015). Em 2017, já são 31 fabricantes instalados no Brasil, com 67 unidades industriais e uma capacidade produtiva de 5,05 milhões de unidades por ano, contribuindo para o emprego de 1,3 milhão de pessoas. Tais números colocam o Brasil como o $10^{\circ}$ maior produtor de veículos do mundo (ANFAVEA, 2017).

Todos os resultados e atividades envolvendo o segmento de veículos são interrelacionados em uma cadeia que envolve diversos setores, desde a extração da matéria-prima até autopeças, montadoras, distribuidoras e prestadoras de serviços (ANFAVEA; CNI, 2012).

Figura 1 - Cadeia Econômica Automotiva.

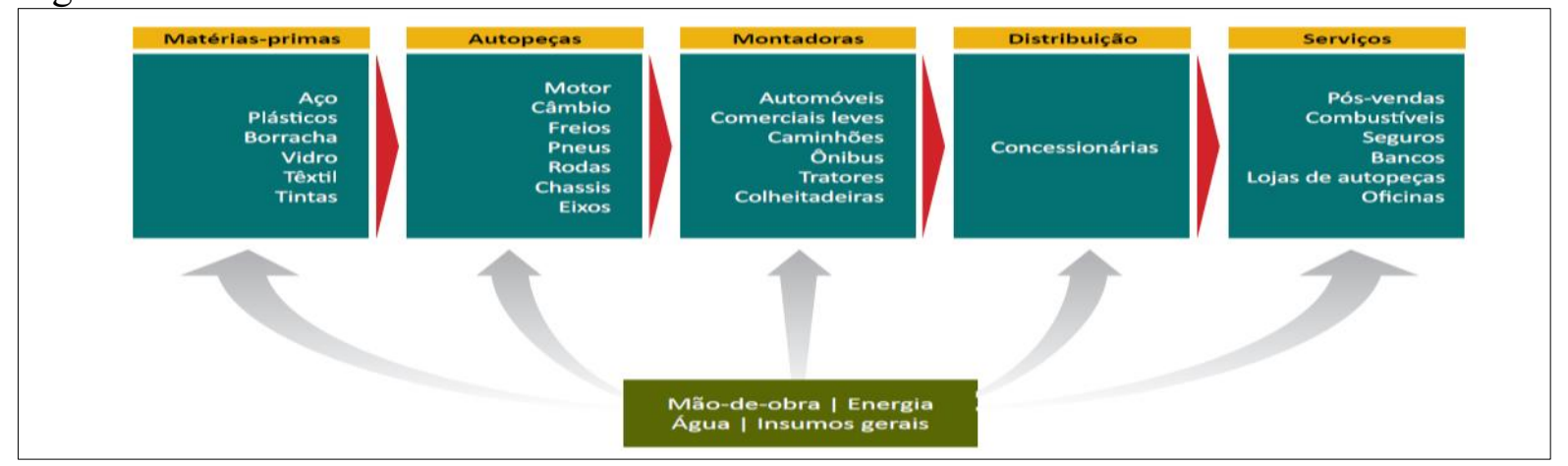

Fonte: ANFAVEA e CNI, 2012.

Dentre as indústrias de veículos, existe a de veículos comerciais, utilizados para o transporte de cargas e passageiros com fins comerciais em rodovias (COM, 1985), que é o caso de caminhões e ônibus (QUINTELLA; ROCHA; ALVES, 2005). Enquanto a Europa possui como modal para transporte de cargas o ferroviário, o Brasil utiliza rodovias. Por isso o setor de veículos comerciais é essencial para escoar a produção nacional, por meio do transporte 
rodoviário de cargas (WANKE; FLEURY, 2006). O setor possuía uma representatividade de $17 \%$ da frota de veículos no Brasil no ano de 2016, apresentando um volume crescente da frota no decorrer dos anos. Em 2000, a estimativa de frota de veículos comerciais circulando no país era de 3,7 milhões de unidades, que aumentou para 7,3 milhões em 2016 (ANFAVEA, 2017).

Ao mesmo tempo que possui uma grande importância na economia, a indústria automotiva é um dos setores que mais gera resíduos em seus processos no Brasil e, em 2010, a geração total foi de aproximadamente 10 milhões de toneladas de resíduos, tanto recicláveis quanto não recicláveis. Os principais resíduos gerados pelo setor são sucata metálica, óleos e tintas, resíduos perigosos e resíduos inertes. Cada um destes resíduos possui diferentes meios de tratamento, sendo que a sucata metálica passa por processos de separação, descaracterização e reciclagem; os óleos e tintas são armazenados, reciclados ou coprocessados; o resíduo perigoso é armazenado, coprocessado ou incinerado; e o resíduo inerte é reciclado ou disposto em aterro industrial (ANFAVEA; CNI, 2012).

Com a influência da indústria em diversos outros setores e os impactos ambientais potenciais ao longo de toda a cadeia, o tema da gestão de resíduos passou a ser de grande importância para as companhias instaladas no Brasil, principalmente após a publicação da Lei 12.305 de 2010, que trata da Política Nacional de Resíduos Sólidos (BRASIL, 2010). Esta lei estabelece um conjunto de atribuições como, por exemplo, a criação de um Plano de Gerenciamento de Resíduos Sólidos para diversos setores. Tal plano visa, por meio da responsabilidade compartilhada, a redução da geração de resíduos sólidos e dos impactos ambientais decorrentes do ciclo de vida dos produtos, além da proteção à saúde humana, conforme texto do seu Artigo 30:

\footnotetext{
Art. 30. É instituída a responsabilidade compartilhada pelo ciclo de vida dos produtos, a ser implementada de forma individualizada e encadeada, abrangendo os fabricantes, importadores, distribuidores e comerciantes, os consumidores e os titulares dos serviços públicos de limpeza urbana e de manejo de resíduos sólidos, consoante as atribuições e procedimentos previstos nesta Seção.

Parágrafo único. A responsabilidade compartilhada pelo ciclo de vida dos produtos tem por objetivo:

II - promover o aproveitamento de resíduos sólidos, direcionando-os para a sua cadeia produtiva ou para outras cadeias produtivas;

III - reduzir a geração de resíduos sólidos, o desperdício de materiais, a poluição e os danos ambientais (BRASIL, 2010, p.18).
}

Neste cenário de grande volume de vendas, influência sobre segmentos industriais e alta geração de resíduos, a indústria automotiva vem recebendo, de diversos agentes, cobranças para uma gestão ambiental cada vez mais proativa, o que traz desafios para manter o seu desenvolvimento, devendo aperfeiçoar seus processos em toda a cadeia para reduzir tanto o 
consumo de insumos e matéria-prima quanto a geração de resíduos. Sendo proativa, a estratégia de gestão ambiental abandona o objetivo de buscar apenas o cumprimento legal, assumindo uma postura de gerenciamento para a prevenção, de forma a antecipar possíveis impactos. Esta mudança no trato da gestão ambiental passou por três etapas: nos anos de 1960 e 1970, as gestões buscavam lidar com crises ambientais por meio de controles; nos anos de 1980, a abordagem era ainda reativa, visando se adaptar rapidamente às mudanças regulamentares ambientais e buscar redução de custos de conformidade; a partir dos anos de 1990, assumiu-se um método mais proativo, em que as organizações passaram a tomar medidas que evitavam impactos, reduzindo desperdícios e riscos de poluição inerentes a seus processos produtivos. Os agentes motivadores para a prática de uma gestão ambiental proativa são: as demandas regulamentares, como legislação mais rígida e aumento de passivos jurídicos; fatores que envolvem custos, como tratamento de resíduos e sistemas de controle; demandas de stakeholders, desde solicitações de órgãos públicos até questionamentos de clientes ou acionistas; e requisitos para a competitividade, como acordos e padrões internacionais (BERRY; RONDINELLI, 1998).

No caso do Brasil, práticas empresariais de gestão ambiental proativa têm demonstrado uma melhora nos indicadores ambientais predominantes na indústria automotiva, que são: o consumo de insumos por veículo produzido, a emissão de gases de feito estufa (GEE), e a geração de resíduos descartados e reciclados (ANFAVEA; CNI, 2012). Adicionalmente, órgãos públicos estão desenvolvendo iniciativas em prol da sustentabilidade do segmento veicular, e um exemplo em discussão é o Programa de Sustentabilidade Veicular. Por meio da criação de um seguro para a sustentabilidade veicular, o programa institui uma política estrutural de caráter ambiental para a contínua renovação e reciclagem da frota brasileira, o que contribui para o crescimento do Produto Interno Bruto e gera empregos na cadeia produtiva, em termos econômicos, e reduz o consumo de combustível e as emissões atmosféricas, em termos ambientais, já que os novos produtos possuem tecnologias de melhor desempenho (BRASIL, 2016).

Com os questionamentos em relação ao modelo econômico linear e a busca por gestões proativas, as chances para o desenvolvimento de organizações e cadeias de valor mais sustentáveis aumentam, já que seu desempenho, em termos econômicos, passa a ser relacionado com a capacidade de suporte ao meio ambiente. Diversas abordagens integram o conceito de sustentabilidade e os sistemas econômicos, mas o modelo econômico que reflete a ideia de sustentabilidade em longo prazo é chamado Economia Circular (PEARCE; TURNER, 1990). 


\subsection{JUSTIFICATIVA E QUESTÃO DE PESQUISA}

$\mathrm{Na}$ Economia Circular, toda a cadeia de valor do produto é levada em consideração, desde a extração de matéria-prima, conversão, fabricação, distribuição, uso e, por fim, a gestão do final de vida, que inclui reuso, reciclagem, recuperação energética, dentre outros meios. Assim, é um modelo que não se baseia no consumo, mas no uso restaurativo, tendo ferramentas como a remanufatura para atingir tal finalidade (GUIDAT et al., 2014). Sua implementação pode ocorrer em níveis micro, meso e macro (GHISELLINI; CIALANI; ULGIATI, 2016).

Quadro 1 - Os níveis de implementação da Economia Circular.

\begin{tabular}{|l|l|l|}
\hline Nível & Participantes & Exemplos de práticas \\
\hline Micro & Consumidores e empresas individuais. & $\begin{array}{l}\text { Programas de produção mais limpa; consumo verde } \\
\text { e compras verdes; decompositores, reciclagem e } \\
\text { reutilização de produtos; políticas corporativas. }\end{array}$ \\
\hline Meso & Parques eco-industriais. & $\begin{array}{l}\text { Sistemas eco-industriais e simbiose de distritos e } \\
\text { redes industriais; mercado de comércio de resíduos; } \\
\text { políticas corporativas e entre companhias. }\end{array}$ \\
\hline Macro & Cidades, regiões e nações. & $\begin{array}{l}\text { Redes e produções eco-industriais regionais, } \\
\text { ecocidades e simbiose urbana; consumo } \\
\text { colaborativo; programas de "resíduos zero" e } \\
\text { sistemas inovadores de gestão de resíduos sólidos } \\
\text { urbanos. }\end{array}$ \\
\hline
\end{tabular}

Fonte: Ghisellini, Cialani e Ulgiati, 2016.

A Europa é um continente onde práticas de Economia Circular estão em estágio mais avançado, se comparada a outros locais. Globalmente, o conceito de Economia Circular emergiu de fato em 2012, quando a Ellen MacArthur Foundation (EMF) publicou o relatório “Em direção a uma Economia Circular" (EMF, 2012), que foi o primeiro de uma série de relatórios que tratam da importância e necessidade de implementação de uma economia gerida de forma circular e restaurativa (AZEVEDO, 2015). Apenas a partir das publicações da Fundação Ellen MacArthur que o Brasil passou a debater o tema Economia Circular. A economia brasileira é baseada na extração de recursos naturais, e acompanhar os debates sobre Economia Circular e refletir academicamente é de grande importância, principalmente devido aos desafios envolvendo a gestão de resíduos e às demandas provenientes da Política Nacional de Resíduos Sólidos, que estabelece as responsabilidades pelo tratamento de diversos rejeitos provenientes de bens de consumo (BRASIL, 2010).

Talvez pelo fato de ser um termo relativamente recente, se comparado às outras áreas de conhecimento, a Economia Circular é questionada por alguns autores. Murray, Skene e Haynes (2017) mencionam que, embora a Economia Circular dê ênfase ao redesenho de 
processos e à circularidade de materiais, o que pode contribuir para modelos de negócios mais sustentáveis, também traz tensões e limitações, como a ausência da dimensão social inerente ao desenvolvimento sustentável. Genovese et al. (2017) apontam que, para que as iniciativas de Economia Circular sejam realizadas, deve existir apoio governamental. Ainda segundo esses autores, a degeneração das matérias-primas em um sistema de produção ao longo do tempo é inevitável, já que os fluxos circulares de trocas são acoplados ao fluxo físico de matéria-energia, que não é circular. Em contrapartida, a EMF (2012) esclarece que o aspecto social da sustentabilidade é intrínseco à Economia Circular, uma vez que sua estratégia de desenvolvimento abrirá novos postos de trabalho. Em relação ao fluxo entre matéria e energia, a Economia Circular incentiva o uso de energias renováveis.

O modelo de Economia Circular possui três princípios, sendo que o princípio 1 trata do consumo de insumos e a gestão de estoques de recursos no meio ambiente; o princípio 2 trata das hierarquias de tratamento de materiais, que são aplicadas em forma de loops na cadeia dos produtos; e o princípio 3 trata das externalidades geradas. Dentro do princípio 2, os materiais são divididos em dois ciclos, o técnico e o biológico. O ciclo técnico possui em seu escopo os materiais tecnológicos e sintéticos fabricados pelo ser humano. O ciclo biológico trata de materiais orgânicos que podem retornar ao meio ambiente como nutrientes (EMF, 2015).

Considerando a importância da Economia Circular, a repercussão do assunto e a baixa quantidade de produção acadêmica sobre o tema, principalmente estudos de caso, além da importância do setor de veículos no desenvolvimento econômico, a questão de pesquisa deste estudo é: como os princípios da Economia Circular podem ser aplicados na cadeia de valor de um produto na indústria de veículos? Para entender esta questão, foi feito um estudo de caso de uma indústria, em diversos processos relacionados ao caminhão, que é um veículo comercial, para estudar práticas que seguem os princípios da Economia Circular.

O estudo foi realizado em uma multinacional alemã que fabrica automóveis e veículos comerciais e possui unidades fabris no Brasil, sendo a maior fabricante de caminhões e ônibus da América do Sul. Suas atividades no país começaram em 1956 e, desde então, já fabricou mais de dois milhões de veículos comerciais. A remanufatura de Câmbios e Motores é uma das unidades de análise estudadas, e que possui alguns elementos dos princípios da Economia Circular. Como foram estudados processos industriais que envolvem materiais técnicos e não biológicos, foi dado enfoque ao ciclo técnico dos materiais. 


\subsection{OBJETIVO GERAL E OBJETIVOS ESPECÍFICOS}

O objetivo deste estudo foi analisar a aplicação dos princípios da Economia Circular na cadeia de valor do caminhão, da indústria de veículos comerciais. Foram estabelecidos os seguintes objetivos específicos:

a) Levantar a estrutura e os princípios da Economia Circular;

b) Identificar elementos da Economia Circular implementados na cadeia de valor do caminhão;

c) Analisar o nível de implementação dos princípios e da estrutura da Economia Circular nas unidades de análise do estudo.

Os princípios da Economia Circular sintetizam em um modelo conceitos e ferramentas de gestão (EMF, 2015; LEWANDOWSKI, 2016), que buscam reduzir tanto o consumo de materiais virgens quanto a geração de resíduos (HAAS et al., 2015), aplicando a circularidade de materiais (MATHEUS; TAN, 2011) para o aperfeiçoamento da cadeia de consumo dos ciclos biológicos e técnicos (BICKET et al., 2014), e para que processos produtivos tradicionais sejam repensados (YUAN; BI; MORIGUICHI, 2006). O pressuposto do trabalho é que as ferramentas de gestão precisam ser aplicadas estrategicamente, considerando a cadeia de valor dos produtos e a circularidade dos materiais, possibilitando o preenchimento de lacunas para se completar uma estrutura de Economia Circular (EMF, 2015).

\subsection{ESTRUTURA DO TRABALHO}

O trabalho está dividido em seis capítulos. O primeiro capítulo, que é esta introdução, trata do consumo de recursos naturais e da geração de resíduos inerentes ao tradicional modelo econômico, bem como da necessidade de aplicação de uma nova economia, que é a circular. Na sequência, são descritas a justificativa e a questão de pesquisa que direcionaram os objetivos geral e específicos do trabalho.

O segundo capítulo apresenta o referencial teórico da Economia Circular, que utiliza principalmente a literatura internacional sobre o tema, de forma a explicar a transição da economia linear para a Economia Circular, os debates em relação ao surgimento do termo, a influência das treze áreas de conhecimento que colaboraram para a criação do conceito, a estrutura do conceito, as críticas de alguns autores e, por fim, exemplos de pesquisas científicas no entorno do assunto. 
O terceiro capítulo discorre sobre o método de pesquisa, apresentando a abordagem metodológica, os instrumentos de coleta de dados e a forma de tratamento e análise dos dados. A abordagem da pesquisa foi qualitativa, de natureza aplicada. A realização dos objetivos foi descritiva e o procedimento utilizado foi um estudo de caso único, com diferentes unidades de análise. No instrumento de coleta de dados, foram utilizadas como fontes de evidências documentos, registros em arquivos, entrevistas e observação direta. Os dados foram triangulados de forma a possibilitar análises.

O quarto capítulo discute os resultados da pesquisa. Nele, são apresentadas a estrutura de um caminhão, as evidências encontradas nas unidades de análise Desenvolvimento de Caminhões, Loja Virtual de Peças, Programa ServicePlus, Programa Service24h, SelecTrucks e Remanufatura, bem como os elementos da Economia Circular presentes em cada uma. Buscando facilitar o estudo das evidências, foram feitos fluxos das contribuições entre as unidades de análise. Para complementar o ciclo das peças e componentes do caminhão, o capítulo é finalizado com a explicação do tratamento de materiais em final de vida.

O quinto capítulo analisa e discute os resultados, triangulando as evidências obtidas por meio dos instrumentos de coleta de dados e das teorias apresentadas no referencial teórico. Os elementos da Economia Circular evidenciados no estudo foram relacionados com as iniciativas de cada uma das unidades de análise. Para descrever os resultados, as evidências foram desdobradas nos seguintes tópicos: elementos da subcategoria 'gestão de fluxo de renováveis e de estoques', 'elementos da subcategoria ciclo técnico', 'elementos da subcategoria externalidades e hierarquia' do ciclo técnico da Economia Circular, na cadeia do caminhão.

O sexto capítulo apresenta as principais conclusões do trabalho, as limitações da pesquisa e recomendações para futuros estudos. 


\section{REFERENCIAL TEÓRICO}

O referencial teórico discute a Economia Circular, descrevendo a transição da economia linear para esse modelo, com a apresentação das áreas de conhecimento que contribuíram para a construção do conceito e de sua estrutura. Em seguida, é abordado o estado da arte de pesquisas científicas relacionadas ao tema. Com este procedimento, estabelecemos as categorias teóricas que contribuíram para o desenvolvimento dos instrumentos de coleta de dados e para a discussão dos resultados.

\subsection{DO MODELO LINEAR PARA O MODELO CIRCULAR}

A Economia Circular é uma nova abordagem de modelo econômico, que possui como premissa o desenvolvimento regenerativo e restaurador, que preserva e reforça o capital natural por meio da otimização do uso de recursos naturais e da minimização dos descartes, gerenciando as reservas e fluxos renováveis e não renováveis (EMF, 2012). Para isso, busca e cria oportunidades para mudar o conceito de "fim-de-vida" para o de "berço ao berço", utilizando energias renováveis e eliminando o uso de produtos químicos tóxicos, além de reduzir a geração de resíduos, por meio de um design superior de materiais, produtos, sistemas e modelos de negócio (LEWANDOWSKI, 2016). Como resultado, espera-se dissociar o crescimento econômico da degradação ambiental, aumentar a rentabilidade e a vantagem competitiva das empresas, e criar oportunidades de trabalho (LINDER; SARASINI; LOON, 2017).

A percepção convencional sobre o sistema econômico é que se trata de um sistema aberto, também conhecido como economia linear ou open-ended. Tal sistema foi desenvolvido sem considerar as possibilidades de reciclagem, tratando o meio ambiente como uma espécie de reservatório de resíduos e com recursos infinitos. Na economia, recursos naturais são transformados em bens de consumo e bens de capital, que devem ser consumidos proporcionando utilidade e bem-estar. Porém, na economia linear, a possibilidade de escassez de recursos naturais é ignorada, bem como os resíduos gerados e seus impactos, devido ao descarte inadequado no meio ambiente (ANDERSEN, 2007).

A economia linear tem como característica a produção e o consumo, e os produtos são fabricados utilizando matérias-primas virgens. Tais produtos são vendidos, utilizados e descartados como resíduos, quando obsoletos. Seu modelo necessita de grandes quantidades de energia e de recursos naturais que são finitos, mostrando ser cada vez mais inadequado em 
termos de sustentabilidade. Mesmo com o avanço tecnológico e a eficiência no uso de recursos, qualquer sistema cujo foco seja o consumo, ao invés de um uso restaurativo, resulta em perdas ao longo de sua cadeia de valor. As iniciativas que trouxeram eficiência produtiva em diversos segmentos, ao longo dos anos, se adotadas sozinhas, trarão melhorias em termos de consumo de recursos e energia, porém irão apenas adiar o inevitável, que é a escassez dos recursos naturais (EMF, 2012).

Considerando a problemática que envolve a economia linear, torna-se necessário o desenvolvimento de uma economia em que nada é desperdiçado, que promova a valorização dos resíduos, e uma gestão em que todos os produtos em final de vida sejam recuperados, reutilizados, remanufaturados ou reciclados por várias gerações (JAWAHIR; BRADLEY, 2016). A Economia Circular é um paradigma de produção e consumo que se afasta do perfil de “extrair, produzir e descartar" proveniente da economia linear (GENG; SARKIS; ULGIATI, 2016). Para ser convertida em uma Economia Circular, a economia linear deve considerar a relação entre o uso de recursos naturais e a geração de resíduos em toda a sua cadeia (ANDERSEN, 2007).

Figura 2 - Sistema linear e Economia Circular

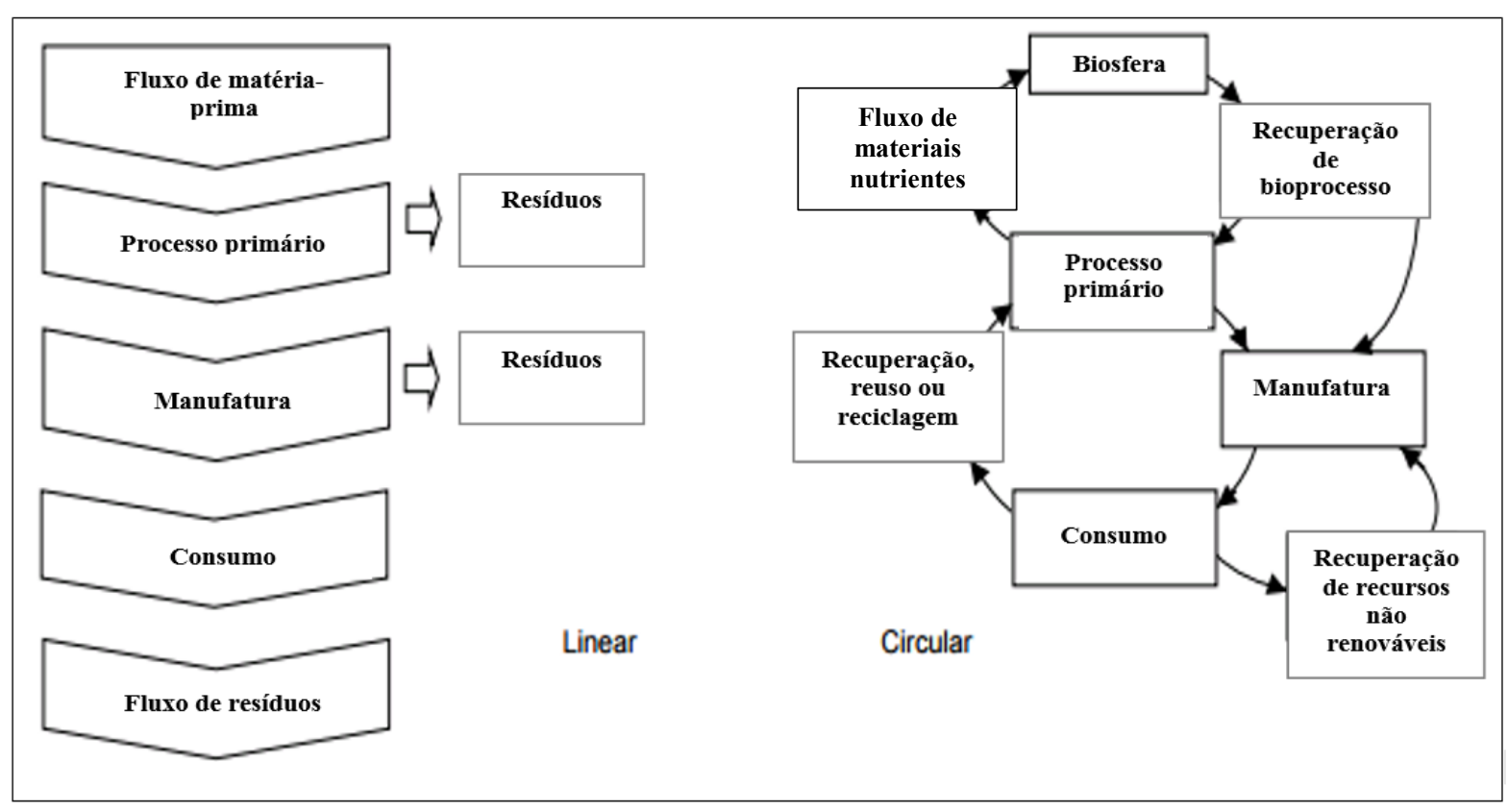

Fonte: Burchart-Korol, Czaplicka-Kolarz e Kruczek, 2015.

O modelo econômico circular é uma alternativa para dissociar o consumo de recursos finitos do desenvolvimento econômico global, preservando e aprimorando o capital natural por meio do aperfeiçoamento da produtividade de recursos e a gestão de estoques finitos e fluxos renováveis. Tal modelo possui como premissa o desenvolvimento de uma economia 
restaurativa e regenerativa, de forma a manter materiais, componentes e produtos em alto nível de utilidade e valor em toda a sua cadeia (EMF, 2012).

Alguns autores registram que o termo "Economia Circular" foi mencionado pela primeira vez por Pearce e Turner em 1990, e que seus princípios foram fundados dentro da disciplina de Economia chamada Ecologia Industrial (ANDERSEN, 2007). Outros afirmam que seu surgimento é complexo, uma vez que sua proposta de desenvolvimento já era debatida por diversas escolas de pensamento. Independentemente de onde surgiu o termo, a ideia de Economia Circular existe há longo tempo, sendo abordada por diversos autores, com opiniões distintas sobre sua origem. Em 1845, o primeiro presidente da Royal Society of Chemistry já afirmava que uma fábrica de produtos químicos ideal era a que não gerava desperdícios, e quanto melhor o uso que se fizesse dos resíduos, maior seria o lucro da companhia (MURRAY; SKENE; HAYNES, 2017). Para outros autores, o homem deve buscar sua inserção em um sistema ecológico cíclico, que torne capaz a reprodução contínua de materiais, mesmo estando sujeito às diferentes entradas de energia, aumentando a durabilidade de produtos (BOULDING, 1966). Ainda utilizando esta ideia de maior durabilidade, o que aumentaria o tempo de uso de materiais para a redução de impactos ambientais, o termo "economia de circuito fechado", do inglês closed-loops, traz um conceito de economia que faz a gestão dos materiais de forma circular (STAHEL; REDAY-MULVEY, 1981).

Nos anos de 1980 surge uma das abordagens mais aceitas, elaborada por Pearce e Turner (1990), que descreve as interações da economia e do meio ambiente em um sistema fechado. Por outro lado, diversos autores afirmam que, ainda naquela década, o termo "Economia Circular" teria surgido de fato na China, inspirado no conceito de circuito fechado reforçado pela abordagem de Ecologia Industrial, que traz modelos de processos industriais que funcionam por meio de fluxos de materiais e energia. Murray, Skene e Haynes (2017) mencionam que muitos problemas ambientais ocorrem pelo fato de os materiais fluírem de forma linear. A Economia Circular seria uma "abreviação da Economia em Ciclos de Materiais Fechados ou Economia Circularizada de Recursos" (YANG; FENG, 2008, p.813) e que "o objetivo das eco-iniciativas é um eventual estabelecimento de uma chamada Economia Circular, também conhecida como uma economia de circuito fechado" (MATHEUS; TAN, 2011, p.436). Apesar de a "Economia Circular" ser associada a diversos autores e abordagens, sua relação com um sistema de circuito fechado e cíclico é comum em todas as descrições (MURRAY; SKENE; HAYNES, 2017).

Para estudar a estrutura da Economia Circular e suas premissas, foram utilizadas principalmente publicações da Fundação Ellen MacArthur (EMF, 2012) e dos autores Murray, 
Skene e Haynes (2015) e Lewandowski (2016), que apresentam as áreas de conhecimento que contribuíram para o surgimento do tema. Dentre as áreas, é possível citar: a economia ambiental (ANDERSEN, 2007; MURRAY; SKENE; HAYNES, 2017), a economia ecológica, os sistemas socioecológicos (MURRAY; SKENE; HAYNES, 2017), a ecologia industrial (EMF, 2012; EMF, 2013; LEWANDOWSKI, 2016; MURRAY; SKENE; HAYNES, 2017), o design regenerativo, a economia de serviços, berço ao berço, a biomimética (EMF, 2012; EMF, 2013; LEWANDOWSKI, 2016), blue economy, a permacultura (EMF, 2013; LEWANDOWSKI, 2016), o capitalismo natural, o metabolismo industrial e, por fim, a simbiose industrial (LEWANDOWSKI, 2016). Todas as treze áreas de conhecimento contribuíram, de alguma forma, para a estruturação da ideia de Economia Circular.

O meio ambiente possui quatro diferentes funções ambientais na perspectiva da economia, que são: os valores de utilidade, a base de recursos para a economia, uma entrada para os fluxos residuais, e um sistema de suporte à vida (PEARCE; TURNER, 1990). Quando respeitadas estas quatro funções como um ponto de partida analítico, os impactos ambientais tendem a ser internalizados, evitando ou compensando prejuízos para as partes interessadas (ANDERSEN, 2007).

Quadro 2 - As quatro funções ambientais na economia.

\begin{tabular}{|l|l|}
\hline Função & Descrição \\
\hline $\begin{array}{l}\text { Valores de } \\
\text { utilidade }\end{array}$ & $\begin{array}{l}\text { Os valores de utilidade são os prazeres que o ambiente pode fornecer diretamente aos seres } \\
\text { humanos, sem a interferência de um sistema econômico. Dentre estes prazeres estão as belezas } \\
\text { das paisagens ou o valor de existência de determinadas espécies que, em caso de deterioração, } \\
\text { tendem a afetar negativamente o bem-estar humano. }\end{array}$ \\
\hline $\begin{array}{l}\text { Base de } \\
\text { recursos para } \\
\text { a economia }\end{array}$ & $\begin{array}{l}\text { O meio ambiente proporciona a base de recursos que funciona como uma entrada para a } \\
\text { economia, tanto em termos de recursos renováveis quanto de recursos não renováveis. Os } \\
\text { recursos são renováveis, desde que a extração não extrapole o seu potencial de renovação e } \\
\text { suprimento pelo meio ambiente. Os recursos não renováveis, porém, trazem maiores } \\
\text { complicações, uma vez que seu estoque físico é limitado e tende a se esgotar, conforme são } \\
\text { consumidos no sistema econômico. }\end{array}$ \\
\hline $\begin{array}{l}\text { Entrada para } \\
\text { os fluxos } \\
\text { residuais }\end{array}$ & $\begin{array}{l}\text { A entrada para fluxos residuais seria uma espécie de coletor para absorção de resíduos } \\
\text { provenientes de atividades econômicas, sejam eles emitidos pelo ar, pela água ou pelo solo. O } \\
\text { meio ambiente possui uma certa capacidade para assimilar os resíduos gerados na economia e, } \\
\text { quando a geração ultrapassa esta capacidade, os impactos ambientais negativos começam a } \\
\text { surgir. }\end{array}$ \\
\hline $\begin{array}{l}\text { Sistema de } \\
\text { suporte } \\
\text { vida }\end{array}$ & $\begin{array}{l}\text { A função do ambiente como um sistema de suporte à vida reconhece o caráter biológico do } \\
\text { meio, e este suporte pode ser influenciado pelos resultados das atividades econômicas. Sendo } \\
\text { assim, a função de suporte à vida para os sistemas biológicos pode ser prejudicada quando o } \\
\text { ambiente é utilizado em excesso na função de pia de resíduos, ou seja, quando fluxos de resíduos } \\
\text { são gerados para o meio, de forma a ultrapassar sua capacidade de assimilação. }\end{array}$ \\
\hline
\end{tabular}

Fonte: Pearce e Turner, 1990.

A Figura 4 apresenta a relação entre as quatro funções, mostrando os fluxos dos aspectos envolvidos neste sistema. Os resíduos descartados, quando ultrapassada a capacidade de 
assimilação pelo meio ambiente, não causam apenas danos ambientais, mas afetam os valores de utilidade e o sistema de suporte à vida, causando também perda na base de recursos para a economia. Esta perda de disponibilidade de recursos pode ser adiada com a implementação de uma Economia Circular, que pratica a reciclagem e a reutilização (ANDERSEN, 2007).

Figura 3 - Fluxo da Economia Circular.

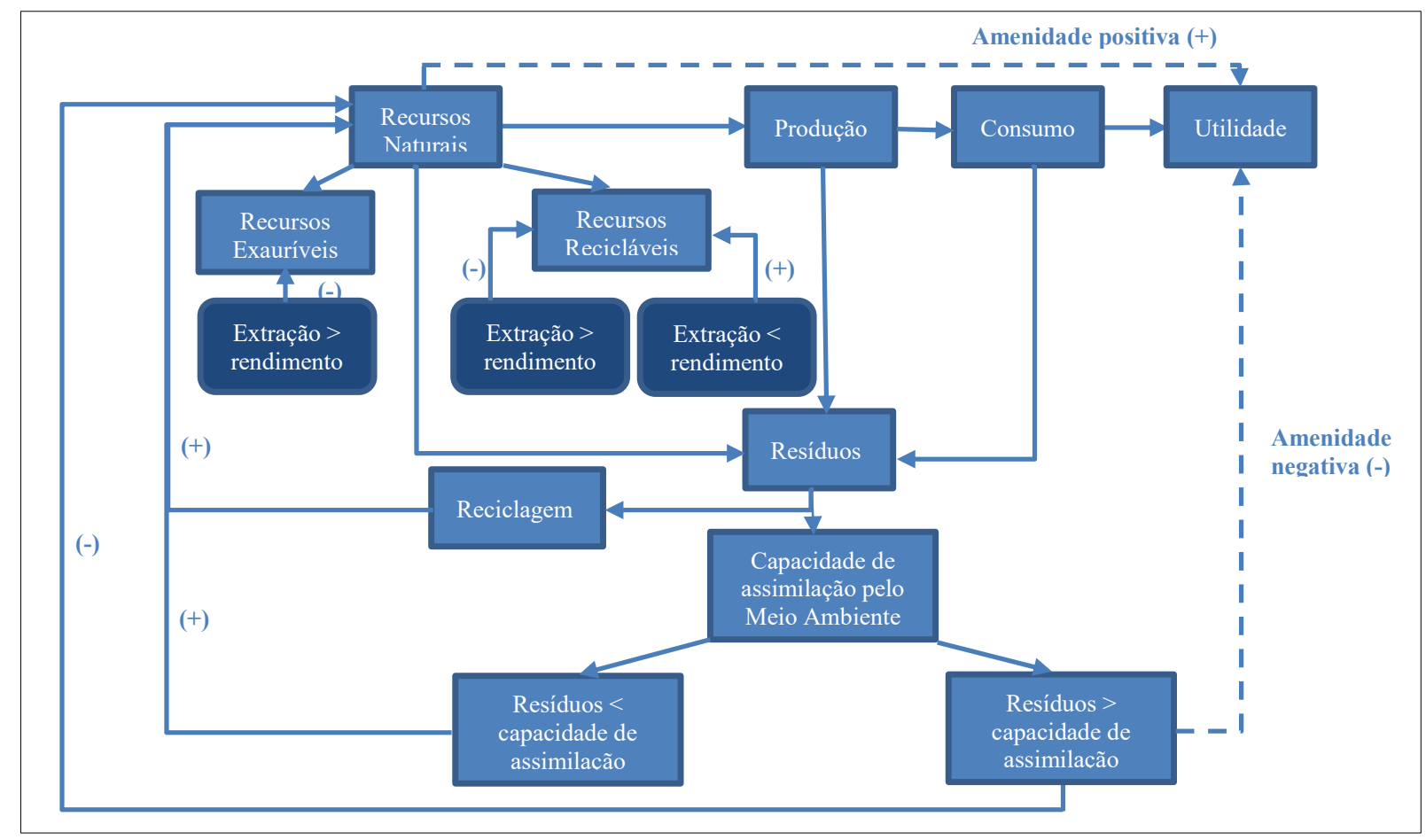

Fonte: Pearce e Turner (1990, apud ENDERSEN, 2007).

A Economia Ecológica integra elementos da economia, ecologia, termodinâmica, ética e diversas outras abordagens de ciências naturais e sociais, o que permitiu estabelecer uma perspectiva integrada das interações do meio ambiente e da economia, visando estruturar soluções para problemas ambientais (COSTANZA, 1992; VAN DEN BERGH, 2001). Os problemas ambientais, de acordo com a área de conhecimento Sistemas Socioecológicos, podem depender de fatores internos ou externos. Os fatores internos podem ser sociais, políticos, ecológicos ou econômicos. Os fatores externos incluem a dívida externa, a pobreza estrutural, os problemas ambientais globais e os conflitos sociais, políticos e econômicos (HOLLING, 2001). A abordagem de Sistemas Socioecológicos surgiu graças a estudos centrados tanto em sistemas ecológicos quanto em sistemas sociais (YOUNG et al., 2006), e reconhece a importância da natureza para o sistema econômico (OSTROM, 2009). Para manter as condições de fornecimento de recursos da natureza para a economia, é preciso desenvolver processos que utilizem as próprias fontes de energia e materiais, visando a criação de sistemas 
sustentáveis aptos a suprir as necessidades humanas e da natureza de forma integrada, ou seja, regenerativos desde o seu design (LYLE, 1996). O Design Regenerativo não está relacionado à autossuficiência ou auto-organização de sistemas vivos, mas ao desenvolvimento que considera a harmonia entre as necessidades do ser humano, de outras espécies e de todo o sistema ecológico (COLE, 2012; MCDONOUGH; BRAUNGAR, 2002). Ainda em relação à importância do meio ambiente para o sistema econômico, a Economia Circular tem como premissa que a natureza possui um grande potencial para gerir questões do homem, e a Biomimética é uma área de conhecimento que estuda as características da natureza, imitandoa de forma a desenvolver soluções para problemas do ser humano (BENYUS, 2002).

Com a industrialização e a evolução dos paradigmas da gestão ambiental e dos interesses na integração de noções de sustentabilidade em sistemas ambientais e econômicos, surgem áreas de conhecimento como o Metabolismo Industrial e a Ecologia Indutrial. O Metabolismo Industrial objetiva obter conhecimento e compreensão do uso que a sociedade faz de recursos naturais, e seus impactos ambientais (ANDERBERG, 1998; AYRES, 1998). A palavra "metabolismo" traz conotação de processos internos de organismos vivos, no contexto original da biologia, e funciona por meio da ingestão de energia e materiais para a promoção de sua manutenção e funcionamento, o que gera resíduos. Neste contexto, há uma analogia entre organismos biológicos e atividades industriais, já que ambos são sistemas de processamento de materiais movidos por fluxos energéticos (AYRES, 1998). Já a Ecologia Industrial estuda os fluxos energéticos e de materiais através de sistemas industriais, e busca o desenvolvimento de processos de circuito fechado para a restauração do capital natural e do bem-estar social. Sua atenção está em considerar não apenas produtos e processos isoladamente, mas sistemas maiores e os impactos de forma mais abrangente, sugerindo desenhos de processos que busquem desenvolver ciclos fechados de materiais, desmaterialização e utilização de energias eficientes (EHRENFELD; GERTLER, 1997). A Ecologia Industrial contribuiu não apenas para o desenvolvimento da ideia de Economia Circular, mas também para o surgimento de outras áreas de conhecimento, como, por exemplo, a Simbiose Industrial, que "engaja setores tradicionalmente separados em uma abordagem coletiva para a vantagem competitiva, envolvendo o intercâmbio físico de materiais, energia, água e subprodutos. As chaves para a simbiose industrial são a colaboração e as possibilidades sinérgicas oferecidas pela proximidade geográfica" (CHERTOW, 2000, p.313), ao aplicar a metáfora ecológica da Ecologia Industrial à ação entre empresas (LOMBARDI; LAYBOURN, 2012). Neste caso, empresas de um mesmo ecossistema industrial aproveitam rejeitos de outras, promovendo uma relação mutuamente 
benéfica, reduzindo impactos ambientais por meio da redução de consumo de recursos naturais e do descarte de resíduos para o meio ambiente (CHERTOW, 2007).

Para desenvolver sistemas regenerativos, que promovem tanto o desenvolvimento econômico quanto o respeito ao meio ambiente, por meio de práticas como a Simbiose Industrial, é preciso desconstruir a abordagem 'do berço ao túmulo' e buscar a do 'berço ao berço', ou seja, não há um final de vida para produtos e sim um novo início, por meio de sua reinserção em novos processos. Mais conhecido em inglês como Cradle to Cradle, o 'berço ao berço' busca o desenho mais eficaz possível dos produtos, maximizando os impactos positivos e reduzindo os impactos negativos ao meio ambiente (EMF, 2013), considerando todo o material envolvido em processos industriais e comerciais. Com isso, espera-se eliminar o conceito de resíduo como descarte, incentivar o uso de energias renováveis e promover o respeito, tanto do homem quanto dos sistemas naturais (MCDONOUGH; BRAUNGAR, 2003). Como resultado, respeita-se o capital natural, que é o valor potencial de recursos naturais, incluindo ativos minerais, biodiversidade e todo o ecossistema de que o ser humano depende para a realização de suas atividades e para seu bem-estar (EMF, 2013). O Capitalismo Natural é uma área de conhecimento que possui como princípios: o aumento da produtividade dos recursos naturais, o direcionamento para materiais e modelos de produção com inspirações biológicas, a mudança para modelos de negócio de "serviços e fluxos", e o reinvestimento no próprio capital natural (HAWKEN; LOVINS A.; LOVINS L., 2008).

Quadro 3 - Princípios do capitalismo natural.

\begin{tabular}{|c|c|}
\hline Princípio & Descrição \\
\hline $\begin{array}{l}\text { Aumento radical da } \\
\text { produtividade dos } \\
\text { recursos naturais. }\end{array}$ & $\begin{array}{l}\text { O potencial de uso dos recursos naturais pode ser aumentado por meio de mudanças } \\
\text { radicais em processos, produtos e tecnologias tradicionais. Como resultado, custos, } \\
\text { necessidade de investimento em capital e desperdício de tempo serão reduzidos. Tais } \\
\text { mudanças também são importantes para a implementação dos outros princípios do } \\
\text { capitalismo natural. }\end{array}$ \\
\hline $\begin{array}{l}\text { Direcionamento para } \\
\text { materiais e modelos } \\
\text { de produção com } \\
\text { inspirações } \\
\text { biológicas. }\end{array}$ & $\begin{array}{l}\text { O capitalismo natural busca a eliminação do desperdício e do conceito de resíduo como } \\
\text { uma perda. Para isso, modela seus sistemas produtivos em ciclos fechados com base } \\
\text { nos meios naturais, e toda a saída do sistema, do inglês output, deve retornar ao } \\
\text { ecossistema como um nutriente, ou se tornar uma entrada, que é um input, em outros } \\
\text { processos produtivos. }\end{array}$ \\
\hline $\begin{array}{l}\text { Mudança para } \\
\text { modelos de negócio } \\
\text { de "serviços e } \\
\text { fluxos". }\end{array}$ & $\begin{array}{l}\text { Buscar desenvolver modelos de negócios com base em fluxos contínuos de serviços, } \\
\text { abandonando o perfil tradicional de venda de produtos. Tal meio alinharia interesses } \\
\text { de fornecedores e clientes, trazendo benefícios diversos como o aumento da } \\
\text { produtividade dos recursos e a redução de desperdícios. }\end{array}$ \\
\hline $\begin{array}{l}\text { Reinvestimento em } \\
\text { capital natural. }\end{array}$ & $\begin{array}{l}\text { Considerando o aumento das demandas e a necessidade de expansão do ser humano, é } \\
\text { preciso reinvestir em capital natural por meio de sua restauração e regeneração. }\end{array}$ \\
\hline
\end{tabular}

Fonte: Hawken, Lovins A. e Lovins L., 2008. 
A Economia de Serviços é uma área do conhecimento que auxilia o reinvestimento no capital natural e a criação de modelos de negócio de "serviços e fluxos", possuindo quatro principais objetivos: a extensão do tempo de vida dos produtos de consumo, a extensão do tempo de vida de bens em geral, a promoção das atividades de recondicionamento, e a redução da geração de resíduos. Para isso, o perfil de negócio deve ser direcionado à venda de serviços e não de produtos, uma ideia referida como a "economia de serviços funcional", agora mais amplamente incorporada dentro do conceito de "economia de serviços". Nesta economia, os produtos físicos, em vez de serem vendidos para os clientes, serão de propriedade das empresas. Os clientes pagam apenas pelo uso e as empresas são responsáveis pela prestação do serviço de forma contínua. Como impacto, é gerado o estímulo para as empresas desenvolverem produtos mais duráveis, de forma a diminuir a obsolescência programada e, consequentemente, o consumo de recursos naturais e a geração de resíduos provenientes de refugos (STAHEL, 2006). O design pensado de produtos para sua circularidade, a economia de serviços, o reconhecimento da importância do meio ambiente para o sistema econômico, a interdependência de processos e companhias, comparando-os a organismos vivos, além da visão do berço ao berço de materiais, quando somados, formam a ideia de Economia Circular, que almeja o desenvolvimento regenerativo e restaurador por meio da gestão consciente do uso de recursos naturais e da geração de rejeitos, e promove do uso de energias renováveis.

Para demonstrar estudos de caso concretos com princípios da Economia Circular, um movimento chamado Blue Economy apresentou ao Clube de Roma um relatório com as "100 inovações que podem gerar 100 milhões de empregos nos próximos 10 anos", que traz iniciativas que transformaram resíduos de produtos em fluxos de entrada de novos processos (EMF, 2013). Modelos de negócio Blue Economy auxiliarão no deslocamento da escassez para a abundância de sociedades, por meio da utilização de recursos locais, tecnologias mais simples, geração de mais valor em vez do corte de custos, e circularidade de materiais (PAULI, 2010).

O quadro 4 traz exemplos de contribuição das treze áreas de conhecimento mencionadas para a Economia Circular.

Quadro 4 - Exemplos de contribuição das áreas de conhecimento para a Economia Circular.

\begin{tabular}{|l|l|l|}
\hline $\begin{array}{l}\text { Área de } \\
\text { conhecimento }\end{array}$ & Exemplos de contribuição para a Economia Circular & $\begin{array}{l}\text { Autores } \\
\text { nas descrições }\end{array}$ \\
\hline $\begin{array}{l}\text { Economia } \\
\text { ambiental }\end{array}$ & $\begin{array}{l}\text { Apresentou as quatro funções do meio ambiente para a economia, } \\
\text { que são: os valores de utilidade, a base de recursos para a economia, } \\
\text { uma entrada para os fluxos residuais e um sistema de suporte à vida. }\end{array}$ & $\begin{array}{l}\text { Pearce; Turner, 1990; } \\
\text { Andersen, 2007. }\end{array}$ \\
\hline
\end{tabular}




\begin{tabular}{|c|c|c|}
\hline $\begin{array}{l}\text { Economia } \\
\text { ecológica }\end{array}$ & $\begin{array}{l}\text { Propiciou o desenvolvimento de uma perspectiva integrada das } \\
\text { interações do meio ambiente e da economia, visando estruturar } \\
\text { soluções para problemas ambientais. }\end{array}$ & $\begin{array}{l}\text { Costanza, 1992; } \\
\text { Van Den Bergh, } \\
2001 .\end{array}$ \\
\hline $\begin{array}{l}\text { Economia } \\
\text { socioecológica }\end{array}$ & $\begin{array}{l}\text { Integrou componentes socioeconômicos e biofísicos, reconhecendo } \\
\text { a importância da natureza para o sistema econômico. }\end{array}$ & $\begin{array}{l}\text { Holling, 2001; } \\
\text { Young, 2006; } \\
\text { Ostrom, 2009. }\end{array}$ \\
\hline $\begin{array}{l}\text { Design } \\
\text { regenerativo }\end{array}$ & $\begin{array}{l}\text { Apresentou a importância da regeneração para possibilitar um } \\
\text { desenvolvimento que respeite as necessidades de todo o } \\
\text { ecossistema. }\end{array}$ & $\begin{array}{l}\text { Lyle, 1996; } \\
\text { McDonough; } \\
\text { Braungart, 2002; } \\
\text { Cole, } 2012 \text {. }\end{array}$ \\
\hline $\begin{array}{l}\text { Economia de } \\
\text { serviços }\end{array}$ & $\begin{array}{l}\text { Por meio de negócios com base em serviços, traz uma economia em } \\
\text { loops, de forma circular. }\end{array}$ & $\begin{array}{l}\text { Stahel, 2006; } \\
\text { EMF, 2013. }\end{array}$ \\
\hline $\begin{array}{l}\text { Do berço ao } \\
\text { berço (cradle to } \\
\text { cradle) }\end{array}$ & $\begin{array}{l}\text { Buscou eliminar o conceito de resíduo como descarte e incentivar o } \\
\text { uso de energias renováveis. }\end{array}$ & $\begin{array}{l}\text { McDonough; } \\
\text { Braungart, 2003; } \\
\text { EMF, 2013. }\end{array}$ \\
\hline $\begin{array}{l}\text { Ecologia } \\
\text { industrial }\end{array}$ & $\begin{array}{l}\text { Apresentou a importância de analisar fluxos energéticos e de } \\
\text { materiais através de sistemas industriais, e incentivou processos que } \\
\text { busquem desenvolver: ciclos fechados de materiais, } \\
\text { desmaterialização e utilização de energias eficientes. }\end{array}$ & $\begin{array}{l}\text { Ehrenfeld; Gertler, } \\
\text { 1997; } \\
\text { EMF, } 2013 .\end{array}$ \\
\hline Biomimética & $\begin{array}{l}\text { Estudou as características da natureza, imitando-a para desenvolver } \\
\text { soluções para problemas do ser humano. }\end{array}$ & s, 2002. \\
\hline Blue Economy & $\begin{array}{l}\text { Promoveu iniciativas que transformaram resíduos de produtos } \\
\text { diversos em fluxos de caixa de novos processos, graças à } \\
\text { circularidade de materiais. }\end{array}$ & $\begin{array}{l}\text { Pauli, 2010; } \\
\text { EMF, } 2013 .\end{array}$ \\
\hline Permacultura & $\begin{array}{l}\text { Promoveu a manutenção de sistemas agrícolas considerando } \\
\text { produtividade, diversidade, estabilidade e resiliência dos } \\
\text { ecossistemas naturais. É evidenciada na Economia Circular, } \\
\text { principalmente no ciclo biológico. }\end{array}$ & EMF, 2013. \\
\hline $\begin{array}{l}\text { Capitalismo } \\
\text { natural }\end{array}$ & $\begin{array}{l}\text { Apresenta como princípios o aumento radical da produtividade dos } \\
\text { recursos naturais, o direcionamento para materiais e modelos de } \\
\text { produção com inspirações biológicas, a mudança para modelos de } \\
\text { negócio de "serviços e fluxos", e reinvestimento em capital natural. }\end{array}$ & $\begin{array}{l}\text { Hawken; Lovins A.; } \\
\text { Lovins L., 2008; } \\
\text { EMF, } 2013 \text {. }\end{array}$ \\
\hline $\begin{array}{l}\text { Metabolismo } \\
\text { Industrial }\end{array}$ & $\begin{array}{l}\text { Estudou as interações entre a energia, os materiais e o ambiente. } \\
\text { Objetiva obter conhecimento e compreensão do uso que a sociedade } \\
\text { faz de recursos naturais e seus impactos ambientais. }\end{array}$ & $\begin{array}{l}\text { Anderberg, 1998; } \\
\text { Ayres, } 1998 .\end{array}$ \\
\hline $\begin{array}{l}\text { Simbiose } \\
\text { industrial }\end{array}$ & $\begin{array}{l}\text { Forneceu uma abordagem coletiva para a vantagem competitiva, em } \\
\text { que empresas de um mesmo ecossistema industrial aproveitam } \\
\text { rejeitos de outras, promovendo uma relação mutuamente benéfica. }\end{array}$ & $\begin{array}{l}\text { Chertow, 2000; } \\
\text { Chertow, 2007; } \\
\text { Lombardi; Laybourn, } \\
2012 .\end{array}$ \\
\hline
\end{tabular}

Fonte: Autor

As ideias apresentadas por cada uma das treze áreas de conhecimento contribuíram para o desenvolvimento da estrutura da Economia Circular, sendo aplicada conforme o contexto da demanda. No próximo item são discutidos os princípios e a estrutura da Economia Circular.

\subsection{A ESTRUTURA E OS PRINCÍPIOS DA ECONOMIA CIRCULAR}

As áreas de conhecimento discutidas no item anterior forneceram bases para os fundamentos da Economia Circular, que são: o design sem resíduo ou o design para o reuso; a criação de resiliência por meio da diversidade; a confiança nas energias provenientes de fontes renováveis; o pensamento sistêmico; e a abordagem segundo a qual resíduo para um pode ser 
alimento para outro, o pensamento em cascata e o compartilhamento de valores (LEWANDOWSKI, 2016).

O design para reuso é um meio de reduzir significativamente a geração de resíduos na cadeia de um produto (EMF, 2012). Fabricantes e designers estão sendo demandados para desenvolver novos produtos que consigam ser reciclados, remanufaturados e reutilizados, quando estiverem no final da vida útil (VILLALBA et al., 2004). Para isso, devem ser aplicadas técnicas de ecodesign, que é a concepção ambientalmente consciente de um produto, de forma a minimizar os impactos negativos provenientes de sua cadeia. Neste contexto está o design para reuso, que traz projetos que visam a reutilização de um produto ou parte dele (ELTAYEB; ZAILANI; RAMAYAH, 2011), sendo auxiliado pelo design modular, que é um meio para projetar produtos que possuem uma característica de alta desmontabilidade, o que facilita a reutilização (GU et al., 1997). Apesar de estes processos serem muitas vezes considerados nas áreas ambientais e negligenciados em questões econômicas, a reutilização de produtos constitui uma significativa fonte de empregos e receitas, quando implementada (WILLIAMS et al., 2008).

Um dos fatores que aumenta a resiliência de um ecossistema é a riqueza da diversidade presente (EMF, 2012). A resiliência é uma medida da persistência dos sistemas e de sua capacidade de absorver mudanças e distúrbios, e ainda manter as mesmas relações entre populações ou variáveis de estado (HOLLING, 1973). Os quatro aspectos que a envolvem são: a latitude, que é o quanto um sistema pode ser alterado antes de perder sua capacidade de recuperação; a resistência, que é a facilidade ou dificuldade de haver mudanças no meio; a precariedade, que mostra quão perto o estado atual está de seu limiar; e a panarquia, que são fatores externos que podem afetar o sistema, como invasões, políticas opressivas, mudanças climáticas globais, que podem desencadear impactos locais, etc. (WALKER et al., 2004). A perspectiva de resiliência é cada vez mais utilizada para a compreensão da dinâmica de sistemas socioecológicos (FOLKE, 2006). Uma resiliência social pode ser definida como a capacidade de grupos ou comunidades de lidar com tensões e distúrbios externos, que podem ser provenientes, por exemplo, de mudanças sociais e políticas ambientais que os afetam, direta ou indiretamente (ADGER, 2000). Existe uma confusão nos conceitos de resiliência e estabilidade. Enquanto a resiliência é a capacidade de um sistema absorver distúrbios e se reorganizar (WALKER et al., 2004), a estabilidade é a capacidade de um meio retornar a um estado de equilíbrio após distúrbios temporários, ou seja, quanto mais rápida a volta ao equilíbrio, mais estável é o sistema (HOLLING, 1973). A diversidade, por sua vez, se refere à diferença, variedade ou abundância de coisas distintas ou divergentes. Organismos, espécies e populações, 
suas variações genéticas e todas as complexas associações de comunidades e ecossistemas formam a biodiversidade, que pode ser discutida em três níveis: a diversidade genética, que se refere aos genes diferentes contidos nas plantas, animais, fungos e microrganismos; a diversidade de espécies, que é toda a diferença dentro e entre populações de espécies, bem como entre espécies diferentes; e a diversidade de ecossistemas, que engloba a variação de habitats, comunidades biológicas e processos ecológicos, além das variações dentro de ecossistemas individuais (GROOMBRIDGE, 1992). Considerando o fato de que todos os organismos, inclusive os seres humanos, modificam o seu ambiente, a proteção ou restauração de ecossistemas representa uma das maneiras mais eficazes de sustentar a diversidade genética e de espécies (VITOUSEK et al., 1997).

A Economia Circular enfatiza a importância do uso de energias renováveis, considerando questões ambientais e sua disponibilidade (EMF, 2012). Fontes convencionais de energia à base de petróleo, carvão e gás natural podem ser eficientes como impulsionadores do progresso econômico, porém são prejudiciais ao meio ambiente e à saúde humana (AKELLA; SAINI; SHARMA, 2009). Neste sentido, a energia renovável tem capacidade de desempenhar um importante papel na sustentabilidade de populações ao redor do mundo (PAINULY, 2001). Fontes de energias renováveis, como pequenas centrais hidrelétricas, energia eólica, solar, biomassa e geotérmica podem fornecer serviços de energia com base no uso de recursos já disponíveis (AKELLA; SAINI; SHARMA, 2009), e, para todas as cadeias de energias renováveis, os insumos de recursos energéticos finitos e as emissões de gases de efeito estufa são baixos em comparação com o sistema energético convencional (PEHNT, 2006).

É essencial para a Economia Circular compreender como as partes de um sistema interagem e se influenciam mutuamente (EMF, 2012). O pensamento sistêmico prevê que o mundo funciona de forma sistematizada, ou seja, os fenômenos ocorrem como uma propriedade emergente de um todo inter-relacionado (FLOOD, 2010), implicando a busca pela compreensão e aperfeiçoamento de uma consciência geral dos sistemas (FORRESTER, 1994). Tal meio de pensamento é uma ferramenta crítica para abordar questões ambientais, sociais e políticas, auxiliando na busca de alternativas para a resoluções de problemas e estabelecimento de melhorias (MEADOWS; WRIGHT, 2008).

Tradicionalmente, a indústria é caracterizada por consumir grandes quantidades de recursos naturais para a realização de seus processos (EL-HALWAGI; GABRIEL; HARREL, 2003). Os elevados custos associados à extração de matérias-primas, os danos ambientais causados pelos processos extrativistas (BRAGANÇA et al., 2006) e a possibilidade de escassez de recursos naturais trazem diversos desafios econômicos, ambientais e sociais (EL- 
HALWAGI; GABRIEL; HARREL, 2003). Uma das alternativas da Economia Circular para reduzir o consumo de recursos naturais é a utilização de resíduos entre sistemas, ou seja, o rejeito de um pode ser a entrada, como insumo ou mesmo matéria-prima, de outros processos, tanto em ciclos técnicos quanto ciclos biológicos (EMF, 2012). Os resíduos de alimentos, por exemplo, podem servir de nutrientes para diversos organismos vivos, ou mesmo serem utilizados como fonte de energia alternativa (HAN et al., 2002). A utilização de biomassa proveniente de resíduos é considerada uma forma ambientalmente segura para fornecer energia, e pode ser realizada tanto no meio industrial quanto público (NARODOSLAWSKY; OBERNBERGER, 1996). Outros exemplos são o uso de subprodutos industriais na fabricação de cimentos (LI et al., 2012), e o uso de sumo de laranja para a fabricação de ração animal, óleo biológico ou carvão vegetal (REZZADORI; BENEDETTI; AMANTE, 2012).

Graças ao capital natural, que é o estoque de recursos naturais que inclui solos, ar, água e todos os organismos vivos (COSTANZA; DALY, 1992), ecossistemas desempenham um conjunto de funções que fornecem bens e serviços para os seres vivos, incluindo a humanidade (CHRISTENSEN et al., 1996). O valor que os indivíduos atribuem ou associam aos bens e serviços provenientes dos ecossistemas é denominado valor ambiental (AMAZONAS, 2016). Os bens fornecidos pelo meio ambiente podem ser comida, materiais para construção, e plantas medicinais. Como serviços, é possível citar a manutenção de ciclos hidrológicos, a regularização climática, a limpeza de água e ar e a ciclagem de nutrientes (CHRISTENSEN et al., 1996). A manutenção do capital natural é essencial para que estes bens e serviços continuem disponíveis, possibilitando a continuidade do desenvolvimento social e econômico do ser humano (TURNER; DAILY, 2008). Para que isso ocorra, é necessário utilizar os valores de forma compartilhada, em que toda a cadeia de um sistema é considerada. No princípio do valor compartilhado, a geração de valor econômico também cria valor para a sociedade, ao reconhecer que a sociedade não é afetada apenas por questões financeiras, mas também pelo desperdício de energia e matéria-prima, por acidentes onerosos, ou por quaisquer externalidades negativas. O valor compartilhado em uma empresa, por exemplo, pode ser aplicado por meio da adoção de políticas e práticas que promovam a melhora das condições sociais e econômicas nas comunidades em que ela atua, com o pressuposto de que o que é bom para a comunidade, é bom para a companhia (PORTER; KRAMER, 2011). O compartilhamento de materiais técnicos é uma prática que não implica a transferência de propriedade (BARDHI; ECKHARDT, 2012), possibilitando o repasse de determinado bem que não é mais útil para um usuário, mas ainda tem potencial de utilidade para outras pessoas, sem necessitar de qualquer tipo de alteração. Desta forma, a vida útil do bem é estendida, sem haver consumo de energia ou de 
insumos inerentes ao próprio processo de manutenção (EMF, 2015). Autores detalham a importância do compartilhamento por meio de perspectivas que são tendências da sociedade moderna, como o "consumo colaborativo" ou "economia compartilhada" (HEINRICHS, 2013). Tais perspectivas são fenômenos econômicos e tecnológicos estimulados pelo desenvolvimento da tecnologia da informação e comunicação, gerando principalmente iniciativas que envolvem plataformas online, como os websites de compartilhamento de bens e serviços, que não necessitam de espaços físicos para o comércio (HAMARI; SJÖKLINT; UKKONEN, 2015). Trocas ou doações de móveis, livros e roupas (BOTSMAN; ROGERS, 2011), compartilhamento de carros, que já é uma iniciativa de diversas montadoras como MercedesBenz e BMW em países europeus (BELK, 2014), e a carona solidária, conhecida como carpooling, são exemplos de práticas que incentivam o consumo colaborativo e a economia compartilhada. O compartilhamento de carros é um exemplo que teve aceitação dos consumidores e, originado na Suíça e na Alemanha há mais de 20 anos, tornou-se uma alternativa popular nos Estados Unidos, gerando uma receita de 253 milhões de dólares em 2009, com expectativas de aumento para mais de 3 bilhões de dólares em 2016 (BARDHI; ECKHARDT, 2012).

Quadro 5 - Descrições dos fundamentos da Economia Circular.

\begin{tabular}{|c|c|}
\hline Fundamentos & Descrições \\
\hline $\begin{array}{l}\text { Design sem } \\
\text { resíduo / design } \\
\text { para reuso }\end{array}$ & $\begin{array}{l}\text { O resíduo inexiste quando componentes, ou nutrientes, de um produto são desenvolvidos } \\
\text { de forma a se encaixar no ciclo de materiais biológicos e técnicos, projetados de forma a } \\
\text { possibilitar sua desmontagem ou remodelação. Os materiais biológicos não são tóxicos, } \\
\text { podendo ser simplesmente compostados no meio natural. Os materiais técnicos devem ser } \\
\text { projetados para serem utilizados novamente, com uso mínimo de energia e com a maior } \\
\text { manutenção de qualidade possível. A reciclagem tende a reduzir a qualidade do material, } \\
\text { precisando da retroalimentação do sistema por meio de inserção de matéria-prima bruta. }\end{array}$ \\
\hline $\begin{array}{lr}\text { Criação } & \text { de } \\
\text { resiliência } & \text { por } \\
\text { meio } & \text { da } \\
\text { diversidade } & \end{array}$ & $\begin{array}{l}\text { Sistemas com diversidade e conexões tendem a ser mais resistentes a impactos externos } \\
\text { do que sistemas construídos simplesmente para buscar eficiência. Modularidade, } \\
\text { versatilidade e adaptabilidade são características importantes em um mundo de rápida } \\
\text { evolução e com diversas incertezas. }\end{array}$ \\
\hline $\begin{array}{l}\text { Confiança na } \\
\text { energia } \\
\text { proveniente de } \\
\text { fontes renováveis }\end{array}$ & $\begin{array}{l}\text { Buscando reduzir impactos ambientais, o uso de energias alternativas deve ser priorizado. } \\
\text { Para possibilitar tal uso em toda a cadeia produtiva, os processos devem ser integrados, } \\
\text { sempre que possível. Por exemplo, a produção agrícola em muitos lugares utiliza energia } \\
\text { solar. Porém, insumos como adubo e outros fertilizantes ainda utilizam combustíveis } \\
\text { fósseis, fazendo com que a cadeia não seja tão sustentável. }\end{array}$ \\
\hline $\begin{array}{l}\text { Pensamento } \\
\text { sistêmico }\end{array}$ & $\begin{array}{l}\text { O pensamento sistêmico se refere à maioria dos sistemas não-lineares, interdependentes e } \\
\text { retroalimentados. A capacidade de compreender como as partes interagem e se } \\
\text { influenciam mutuamente é essencial para a Economia Circular. Tais sistemas exigem uma } \\
\text { gestão mais flexível, em constante adaptação às circunstâncias. }\end{array}$ \\
\hline
\end{tabular}


Conclusão

O resíduo para um O rejeito de um processo pode ser matéria-prima ou insumo para outro. Para os materiais pode ser alimento biológicos, a criação de valor ocorre da possibilidade de extração de utilidade adicional de para outro; o produtos e materiais, direcionando-a em cascata para outras aplicações. Uma árvore pensamento em cortada, por exemplo, que é direcionada para um forno visando a geração de energia, cascata; e o compartilhamento de valores. poderia ser mais bem aproveitada, considerando as etapas de decomposição e os usos sucessivos da madeira e outros produtos, antes da degradação e eventual incineração. Para os materiais técnicos, o rejeito de um processo produtivo pode ser entrada de outro

Fonte: EMF, 2012. processo, como insumo ou matéria-prima.

Os fundamentos, por sua vez, foram simplificados e incrementados na estrutura da Economia Circular, formando três princípios bases (EMF, 2015):

Princípio 1: Preservar e aprimorar o capital natural, controlando estoque finitos e equilibrando os fluxos de recursos renováveis;

Princípio 2: Otimizar o rendimento de recursos, fazendo circular produtos, componentes e materiais no mais alto nível de utilidade, o tempo todo, tanto no ciclo técnico quanto no biológico.

Princípio 3: Estimular a efetividade do sistema, revelando e excluindo as externalidades negativas desde o princípio (EMF, 2015, p.7).

O primeiro princípio recomenda a desmaterialização de produtos e serviços e, havendo necessidade de recursos, estes devem ser selecionados de forma consciente, priorizando os recursos renováveis ou aqueles que possuem melhor desempenho. O capital natural é aperfeiçoado por meio do estímulo de fluxos de nutrientes que possibilitam condições para sua regeneração. O segundo princípio trata dos ciclos técnico e biológico dos materiais. No ciclo técnico estão os tratamentos para produtos em final de vida, que são a manutenção, a reutilização e redistribuição, a remanufatura e, por fim, a reciclagem. Para a Economia Circular, projetos devem ser desenhados para permitir a aplicação do segundo princípio, possibilitando que componentes e materiais técnicos continuem circulando e contribuindo para a economia. Em relação ao ciclo biológico, produtos devem ser projetados para ser consumidos ou metabolizados pela economia e, ao mesmo tempo, devem possuir condições de serem regenerados no meio ambiente, extraindo mais valor de seus componentes e aproveitando-os em cascata para outras aplicações. Tal processo estimula a reinserção de nutrientes biológicos na biosfera para decomposição, transformando-os em matéria-prima para novos ciclos. $\mathrm{O}$ terceiro princípio busca a redução de impactos negativos, considerando áreas diversas como: alimentos, mobilidade, habitação, educação, saúde, uso da terra, ar e água, dentre outros (EMF, 2015). 
Figura 4 - A estrutura da Economia Circular.

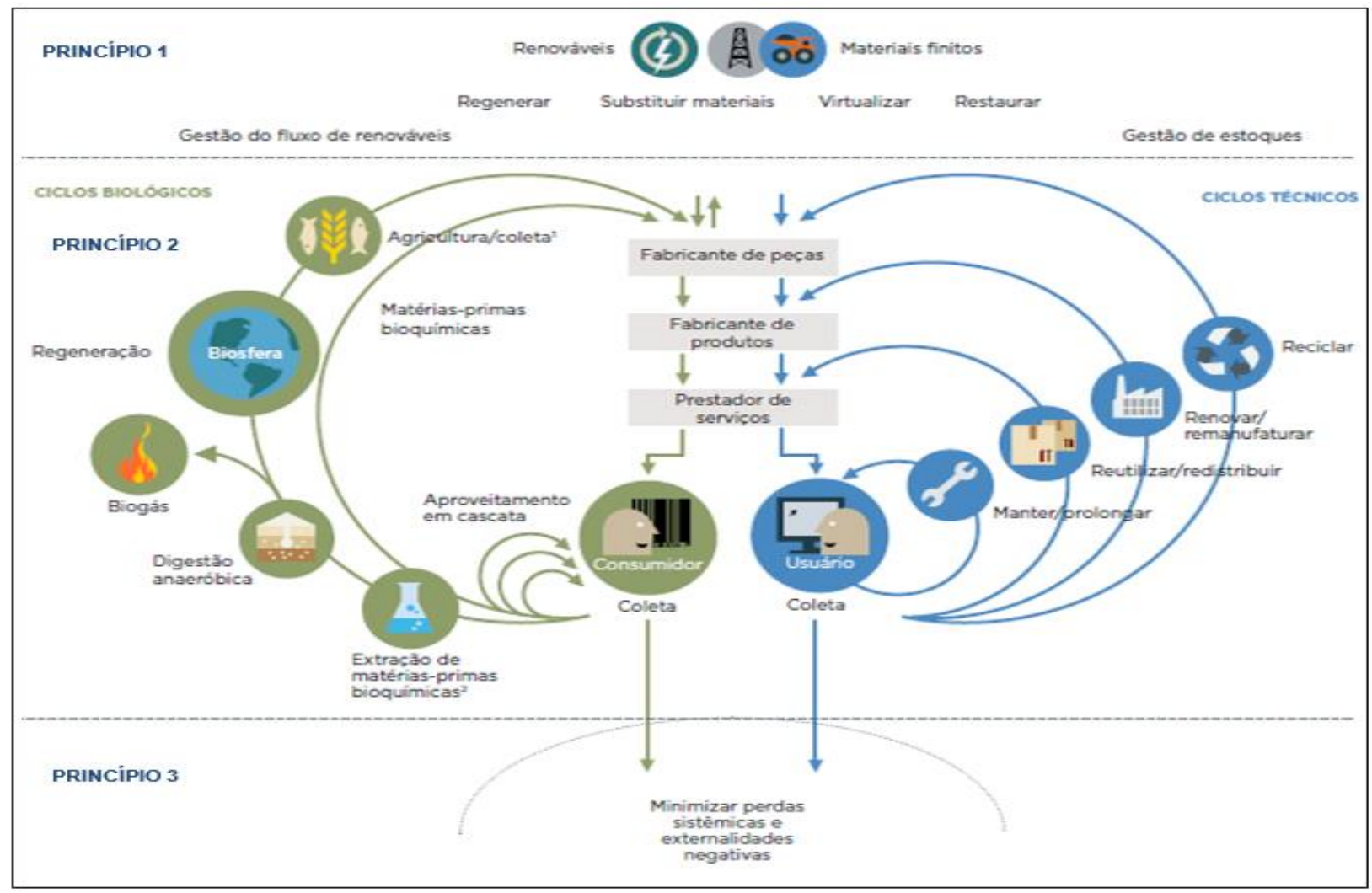

Fonte: EMF, 2015.

Todos os três princípios estão inseridos na estrutura da Economia Circular, que apresenta etapas de circularidade conforme hierarquias de tratamentos para os materiais.

\subsubsection{Princípio 1: a gestão de fluxos renováveis e de estoques.}

O princípio 1 da Economia Circular trata da busca pelo controle de estoques finitos e pelo equilíbrio dos fluxos de recursos renováveis, de forma a preservar e aprimorar o capital natural. Por meio da regeneração, substituição de materiais, virtualização e restauração (EMF, 2015), são geridos os fluxos renováveis, que podem ser de materiais circuláveis no sistema ou de energias renováveis (KORHONEN; WIHERSAARI; SAVOLAINEN, 2001; MELLINO et al., 2014), e de estoques, que se referem ao capital natural (WACKERNAGEL; REES, 1997; LIU et al., 2010). A desmaterialização dos produtos e serviços, que é a redução da inserção de materiais físicos no ciclo econômico (HINTERBERGER; SCHIMIDT-BLEEK, 1999), é uma oportunidade para iniciativas como compras virtuais, que reduzem o uso de materiais físicos (EMF, 2015). Junto ao aumento da reciclabilidade, para proporcionar o retorno dos materiais a ciclos produtivos, de preferência utilizando energias renováveis como a solar, a 
desmaterialização de produtos permite que a economia continue a gerar um fluxo crescente de bens e serviços, e um fluxo decrescente de insumos físicos não renováveis (AYRES, 1997).

Em relação ao capital natural, este consiste no estoque de ativos naturais capazes de produzir fluxos sustentáveis (WACKERNAGEL; REES, 1997), ou seja, são componentes do meio ambiente que proporcionam benefícios às pessoas e à sociedade como um todo, podendo ser desde bens até serviços (LIU et al., 2010).

Quadro 6 - Quadro síntese do princípio 1 da Economia Circular

\begin{tabular}{|c|c|c|c|}
\hline Categorias & Subcategorias & Definições & Autores utilizados \\
\hline \multirow[t]{2}{*}{$\begin{array}{l}\text { Gestão do } \\
\text { fluxo de } \\
\text { renováveis } \\
\text { e de } \\
\text { estoques }\end{array}$} & Desmaterialização & $\begin{array}{l}\text { É uma alternativa para a promoção da gestão } \\
\text { de materiais renováveis e de estoque, } \\
\text { aumentando o fluxo de bens e serviços e } \\
\text { reduzindo o fluxo de insumos físicos não } \\
\text { renováveis. }\end{array}$ & $\begin{array}{l}\text { Ayres, 1997; Hinterberger; } \\
\text { Schimidt-Bleed, 1999; } \\
\text { Korhonen; Wihersaari; } \\
\text { Savolainen, 2001; Mellino } \\
\text { et al., 2014; EMF, 2015. }\end{array}$ \\
\hline & $\begin{array}{l}\text { Conservação do } \\
\text { capital natural }\end{array}$ & $\begin{array}{l}\text { Refere-se à conservação do capital natural, } \\
\text { que é a soma de todos os benefícios } \\
\text { proporcionados pelo meio ambiente, podendo } \\
\text { ser bens, como água potável e alimentos, ou } \\
\text { serviços ecossistêmicos, como purificação da } \\
\text { água e do ar ou decomposição de resíduos. }\end{array}$ & $\begin{array}{l}\text { Wackernagel; Rees, 1997; } \\
\text { Liu et al., 2010; EMF, } \\
2015 .\end{array}$ \\
\hline
\end{tabular}

Fonte: Autor

O estímulo de fluxos de nutrientes dentro de um sistema, que é uma prática da Economia Circular, o preserva e beneficia, além de criar condições necessárias para a regeneração do meio em que estiver inserido (EMF, 2015).

\subsubsection{Princípio 2: os ciclos biológico e técnico}

O princípio 2 da Economia Circular visa a melhoria do rendimento de recursos por meio da circularidade de produtos, componentes e materiais, de forma a aumentar sua utilidade para o máximo de sua vida, tanto no ciclo técnico quanto no ciclo biológico (EMF, 2015). Para isso, é preciso considerar a circularidade dos produtos e processos já em sua concepção, de modo que possam ser introduzidos materiais ou serviços que, ao final de sua vida útil, sejam utilizados como matéria-prima para outro produto num ciclo técnico, ou como nutrientes num ciclo biológico (VOORTHUIS; GIJBELS, 2010). Tal circularidade deve respeitar a hierarquia da estrutura da Economia Circular, visando os menores circuitos, como, por exemplo, aplicando a manutenção antes da reciclagem (EMF, 2015).

$\mathrm{O}$ respeito à hierarquia significa priorizar os circuitos menores, em que recursos são preservados, tanto em termos de matéria-prima quanto de energia, e o tempo de vida do produto é maximizado. No que diz respeito ao ciclo biológico, produtos são projetados para ser 
metabolizados pela economia e gerar novos recursos. Os sistemas circulares estimulam a reinserção de nutrientes biológicos na biosfera para decomposição, transformando-os em matérias-primas para novos ciclos. A essência do valor dos materiais biológicos está no potencial de extração do seu uso em cascata, ou seja, em outras aplicações, conforme a transição para novos ciclos (EMF, 2015).

\subsubsection{O ciclo biológico da Economia Circular}

Um dos princípios da ecologia é que as interações dos organismos e do ambiente são recíprocas, ou seja, tanto o ambiente determina as condições sob as quais a vida existe, quanto os organismos influenciam as condições que prevalecem no seu ambiente (REDFIELD, 1958). O ciclo biológico abrange os fluxos de materiais renováveis que são, em sua maior parte, regenerados no meio ambiente dentro deste mesmo ciclo. Como na Economia Circular o rejeito não é um resíduo e sim um nutriente potencial (EMF, 2015), os materiais que seriam descartados podem ser denominados simplesmente "materiais".

No ciclo biológico, o aproveitamento em cascata, que é o primeiro ciclo dentro da estrutura da Economia Circular, deve ser priorizado, ou seja, materiais podem ser utilizados como nutrientes ainda pelo consumidor. O segundo ciclo é referente ao uso dos materiais como matérias-primas bioquímicas, mas não mais pelo consumidor e sim pelo próprio fabricante. Já no terceiro ciclo, o material atinge o meio ambiente, porém de forma regenerativa, sendo absorvido como nutriente e não como um agente causador de danos (EMF, 2015). Um exemplo de caso de restauração do ciclo biológico ocorre numa região da Itália, onde municípios realizam a coleta separada de resíduos alimentares de famílias e de restaurantes, e incentivam a compostagem doméstica, de forma a criar compostos comercializáveis e evitar o descarte de resíduos orgânicos em aterros. No caso, em vez de utilizar sacos plásticos pretos para armazenar alimentos, foram introduzidos sacos biodegradáveis para a realização da compostagem em locais, preferencialmente, próximos (MURRAY, 2002).

\subsubsection{O ciclo técnico da Economia Circular}

“O ciclo técnico envolve a gestão dos estoques de materiais finitos. [...] Os materiais técnicos são recuperados e, em sua maior parte, restaurados no ciclo técnico" (EMF, 2015, p.8). Estão no escopo deste ciclo produtos compostos por materiais que não são facilmente biodegradados, devendo eles ser desenhados para buscar o máximo possível a circularidade em ciclos fechados (MCDONOUGH; BRAUNGART, 1998). O ciclo técnico da Economia 
Circular possui quatro diferentes hierarquias, que são: a manutenção, a reutilização e a redistribuição, a remanufatura e a reciclagem. Tais hierarquias possuem uma ordem de prioridade para o tratamento dos materiais, conforme o grau de benefícios ao meio ambiente e facilidade em sua circularidade. A manutenção deve ser priorizada, e a reciclagem deve ocorrer apenas na impossibilidade de aplicação do reuso, da redistribuição ou da remanufatura (EMF, 2015).

Quadro 7 - Tratamentos dos materiais técnicos conforme hierarquia da Economia Circular.

\begin{tabular}{|l|l|}
\hline $\begin{array}{l}\text { Tratamentos dos } \\
\text { materiais conforme } \\
\text { hierarquia da } \\
\text { Economia Circular. }\end{array}$ & Definições no contexto da Economia Circular \\
\hline Manutenção & $\begin{array}{l}\text { Deve ser priorizada, pois além de não exigir processos produtivos robustos, o que } \\
\text { geraria custos e poderia trazer impactos ambientais, não sai do ciclo do usuário, ou } \\
\text { seja, seu fluxo ocorre entre as pessoas que utilizam o material. }\end{array}$ \\
\hline $\begin{array}{l}\text { Reuso } \\
\text { redistribuição. }\end{array}$ & $\begin{array}{l}\text { Assim como a manutenção, o reuso e a redistribuição não demandam processos } \\
\text { produtivos robustos. Entretanto, apesar de o novo uso do produto ocorrer para os } \\
\text { mesmos fins em que foi desenhado, há uma tendência de perda de parte de seu valor } \\
\text { agregado, e a circularidade pode ocorrer entre usuários não próximos ou entre um } \\
\text { usuário e um prestador de serviços. }\end{array}$ \\
\hline Remanufatura. & $\begin{array}{l}\text { A remanufatura, diferentemente dos dois tratamentos anteriores, exige um processo } \\
\text { produtivo mais robusto. Porém, o produto é renovado e seu ciclo de uso é aumentado, } \\
\text { o que reduz impactos ambientais provenientes da extração de matérias-primas para } \\
\text { novos produtos, e do descarte de resíduos devido ao sucateamento do material. }\end{array}$ \\
\hline Reciclagem. & $\begin{array}{l}\text { A reciclagem, apesar de ser considerada um tratamento de produtos em fim de vida, } \\
\text { traz uma depreciação na composição dos materiais, o que gera perda de valor. } \\
\text { Adicionalmente, a reciclagem também exige processos produtivos robustos, se } \\
\text { comparada ao reuso e à manutenção. Por isso, de acordo com a Economia Circular, } \\
\text { deve ser utilizada em último caso. }\end{array}$ \\
\hline
\end{tabular}

Fonte: EMF, 2015.

Apesar da existência das hierarquias, todas os tratamentos são pensados de forma a evitar que os materiais sejam descartados no meio de forma inadequada, o que geraria impactos negativos (EMF, 2015).

\section{a) Manutenção}

O loop da manutenção ocorre entre os usuários (EMF, 2015), e existem três tipos de manutenção, que são a corretiva, a preventiva e a preditiva (ABNT, 1994). A manutenção corretiva ocorre após determinada falha no processo, não havendo intervenções antes da ocorrência. A manutenção preventiva se baseia nas características de confiabilidade dos componentes, e, devido a seu comportamento, permitem a definição de um programa de manutenção periódica, visando reduzir e até eliminar a quantidade de falhas possíveis. A manutenção preditiva, diferentemente da preventiva, que possui um plano sistemático, é um 
conjunto de ações para acompanhamento de variáveis de determinado processo, e prevê quando o processo alcançará ou ultrapassará seu limite, o que pode gerar a falha. Com isso, é possível estabelecer quando deverá ser feita a verificação operacional (BEVILACQUA; BRAGLIA, 2000).

\section{b) Reuso e redistribuição}

Enquanto a reciclagem necessita de um reprocessamento do material para que ele seja inserido novamente no ciclo, a reutilização dispensa tal prática. Neste caso, o produto pode ser reaproveitado de diversas formas, não precisando ser transformado em um novo produto. Ela é preferível à reciclagem, uma vez que utiliza menos energia e recursos para sua aplicação (ALSALEM; LETTIERI; BAEYENS, 2009). Porém, para que seja aplicado o reuso, em vez da reciclagem, o produto ou material deve estar em condições de uso, podendo circular até seu fim de vida, ou seja, até atingir um estado em que não possa mais ser utilizado (OLIVEIRA; SILVA, 2011). A redistribuição é aplicada junto com o reuso, uma vez que o material é transferido para outros usuários, que irão utilizá-lo para fins diversos.

No caso de produtos com diversas partes, é importante criar um meio de aplicação do reuso, já em seu projeto (KIMURA et al., 2001). Neste cenário, o reuso consiste em um processo de desmontagem para recuperar peças e conjuntos utilizáveis em outros produtos, com a mesma ou diferente finalidade (BRISSAUD; TICHKIEWITCH; ZWOLINSKI, 2006). A modularização adequada do produto, criando conjuntos, ajuda a aumentar a possibilidade de reutilização, sendo cada módulo uma unidade de reuso que pode ser uma única peça ou um conjunto. Para decidir o conteúdo de cada módulo, são levados em consideração os elementos comuns entre os produtos, a autonomia funcional, custos, facilidade de fabricação e manutenção, estabilidade tecnológica, e facilidade de garantia da qualidade e de reparação (KIMURA et al., 2001).

$\mathrm{Na}$ indústria automotiva, o reuso é uma hierarquia de recuperação de produto de grande importância. As peças ou componentes veiculares que não sofreram deterioração excessiva, por exemplo, podem ser utilizados na remontagem, o que resulta em economia no consumo de energia, em possíveis emissões, nos custos relacionados à produção e montagem, e nos volumes de materiais virgens adquiridos (AMELIA et al., 2009). 


\section{c) Remanufatura}

O consumo e a produção sustentáveis só serão possíveis em sistemas cíclicos, em que recursos são recuperados a partir do fluxo de resíduos no fim da vida de um produto. Entretanto, sistemas que circulam materiais apenas por meio da reciclagem são ligeiramente mais eficientes em termos ambientais e econômicos, se comparados aos tradicionais, em que produtos obsoletos são descartados como resíduos. Devolver ao ciclo produtivo componentes e subprodutos com características de novos, em vez de utilizar matérias-primas recicladas para novos processamentos, é uma via mais ecoeficiente em termos de consumo de recursos naturais e energia. Tal devolução ocorre graças ao processo de remanufatura, que restaura produtos ou componentes usados para a condição de novos, através da recomendação ou da reconstrução parcial (KERR; RYAN, 2001).

A importância da remanufatura de produtos usados em novos produtos tem sido amplamente reconhecida na literatura e na prática (SAVASKAN; BHATTACHARYA; VAN WASSENHOVE, 2004). Ela representa uma forma mais elevada de reutilização, concentrandose na recuperação de valor agregado em vez da recuperação de materiais, que é o caso da reciclagem. Sua prática fecha o ciclo de uso dos materiais, formando um sistema de fabricação que considera a circularidade (GUIDE, 2000). Seu processo possui essencialmente as etapas de inspeção, desmontagem, limpeza, substituição ou remodelação de peças, remontagem, e testes para garantir o atendimento aos padrões desejados (BRISSAUD; TICHKIEWITCH; ZWOLINSKI, 2006). De forma contextualizada, Lund (1983) descreve a remanufatura como sendo:

\footnotetext{
... um processo industrial em que os produtos desgastados são restaurados em condição como novos. Através de uma série de processos industriais em um ambiente de fábrica, um produto descartado é completamente desmontado. As peças utilizáveis são limpas, remodeladas e colocadas no inventário. Em seguida, o novo produto é remontado das peças antigas e, se necessário, novas, para produzir um desempenho totalmente equivalente e, por vezes, superior, ao esperado tempo de vida do novo produto original (LUND, 1983, p.19).
}

Os fabricantes de bens duráveis e não duráveis cada vez mais estão estabelecendo sistemas de produção e distribuição que permitem, junto com a manufatura de novos produtos, a remanufatura de usados (SAVASKAN; BHATTACHARYA; VAN WASSENHOVE, 2004). O desenvolvimento de produtos recuperáveis está impulsionando a indústria para uma produção mais consciente em termos de meio ambiente, já que tais produtos possuem uma vida útil maior graças ao seu potencial de reparação ou remanufatura, fornecendo ao cliente a oportunidade de 
adquirir um bem que atenda aos padrões originais a um preço inferior, se comparado ao produto novo (JAYARAMAN; GUIDE JR; SRIVASTAVA, 1999). A remanufatura de produtos os atualiza aos padrões de qualidade de novos, podendo ser vendidos novamente, pelo fato de cumprirem os requisitos dos novos mercados (SAVASKAN; BHATTACHARYA; VAN WASSENHOVE, 2004), e, sob a perspectiva da competitividade, a remanufatura é uma estratégia de marketing eficaz, já que permite ao fabricante defender seu market share por meio de práticas diferenciadas de preço e benefícios (ATASU; SARVARY; VAN WASSENHOVE, 2008). Os produtos a serem remanufaturados podem ser retornados de diversas formas, como retornos comerciais, reparos ou devoluções de garantia, políticas de coleta de produtos em final de vida, etc. Companhias como HP, Bosch e Xerox vendem produtos remanufaturados junto aos produtos novos, com preços mais competitivos (AGRAWAL; ATASU; VAN ITTERSUM, 2015).

A remanufatura é um processo para produtos em final de vida amplamente utilizado na cadeia automotiva, já que sua aplicação recupera o valor dos materiais, que assumem as características de produtos fabricados pela primeira vez. Dentre os principais componentes veiculares remanufaturados estão embreagens, sistemas de freio, blocos de motor, sistemas de partida, alternadores, bombas de água e carburadores. Entretanto, estes componentes remanufaturados têm sido utilizados no mercado de reposição, e não em novos automóveis (AMELIA et al., 2009).

Em relação às pesquisas científicas envolvendo a remanufatura no segmento automotivo e a Economia Circular, revisões da literatura e estudos de caso têm sido realizados para entender o estado da arte do tema, e trazer práticas de Economia Circular que utilizam a remanufatura de materiais em final de vida.

O investimento na indústria de remanufatura é uma das principais estratégias da China para promover a Economia Circular (ZHANG; CHEN, 2015). Aplicando uma abordagem qualitativa para analisar o desenvolvimento da remanufatura de componentes automotivos naquele país, foi realizada uma revisão da literatura, que levantou problemas e barreiras do tema, considerando fatores técnicos, políticos, sociais e mercadológicos que influenciam o processo. O estudo mostra que na China a legislação impulsionou o tema, como a Lei da Promoção da Economia Circular. Para explicar o desenvolvimento da remanufatura no país, destacam-se três medidas: o incentivo governamental, o direcionamento tecnológico e a liderança de mercado. $\mathrm{O}$ incentivo governamental tem como função estabelecer sistemas de produção e consumo, incentivando o mercado da remanufatura. O direcionamento tecnológico estimula a indústria a estabelecer, em curto prazo, processos eficientes para remanufaturar 
produtos, trazendo vantagem competitiva e possibilitando alcançar a liderança de mercado. Analisando o cenário e as medidas, foram sugeridos: o desenvolvimento de regulamentações específicas de remanufatura pelo governo; a criação de padrões de qualidade de produtos remanufaturados pela indústria; e maior atenção a projetos de remanufatura pela comunidade científica, sendo esta a recomendação para futuros estudos sobre o tema na China (ZHANG et al., 2011).

Ainda sobre o processo de remanufatura na China e sua importância na Economia Circular, foi realizado um estudo do impacto das normas chinesas de emissões veiculares na remanufatura de motores a diesel. A pesquisa apresenta características e tendências da indústria de remanufatura de motores na China, levantando suas aplicações, e, por meio do método de avaliação do ciclo de vida, compara os resultados com as regulamentações sobre o tema (ZHANG; CHEN, 2015).

Figura 5 - A aplicação da remanufatura de motores na China até 2015.

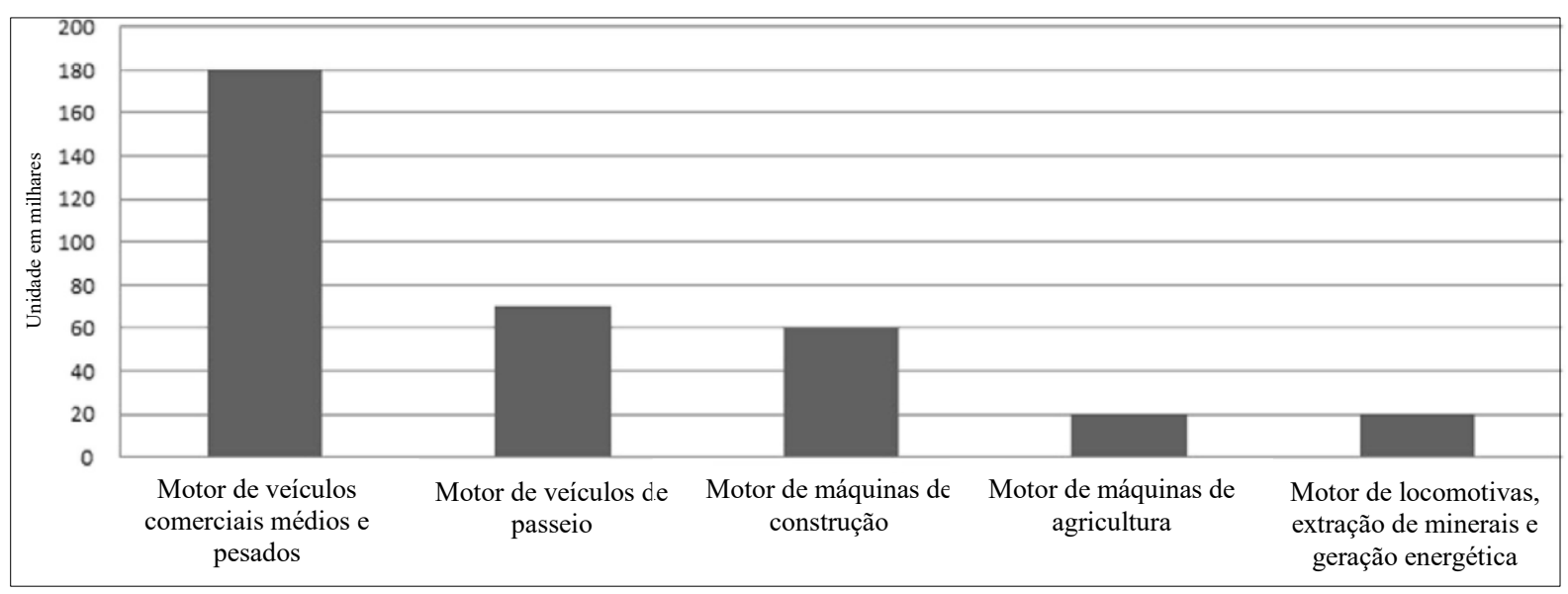

Fonte: Zhang e Chen, 2015, p.177.

Como resultado, uma grande diferença em termos de emissões foi verificada em dois modelos de motores, na fase de uso do ciclo de vida. Isso ocorreu devido ao período em que eles foram fabricados e às regulamentações vigentes em cada época. Considerando que as leis ficam cada vez mais rigorosas, em termos de controle de impactos ambientais, a premissa da remanufatura, de que um produto remanufaturado deve ter a qualidade e a funcionalidade original, não é aplicável, já que, para serem comercializados novamente, os motores devem respeitar a legislação vigente. Os resultados mostraram que, devido às diferenças dos motores e seus fatores de emissão, que seguem os requisitos da época em que foram fabricados, é necessário adotar diferentes estratégias de remanufatura para cada tipo de produto, para que ele seja comercializado (ZHANG; CHEN, 2015). 
Figura 6 - Fluxo do ciclo de vida do motor e da remanufatura.

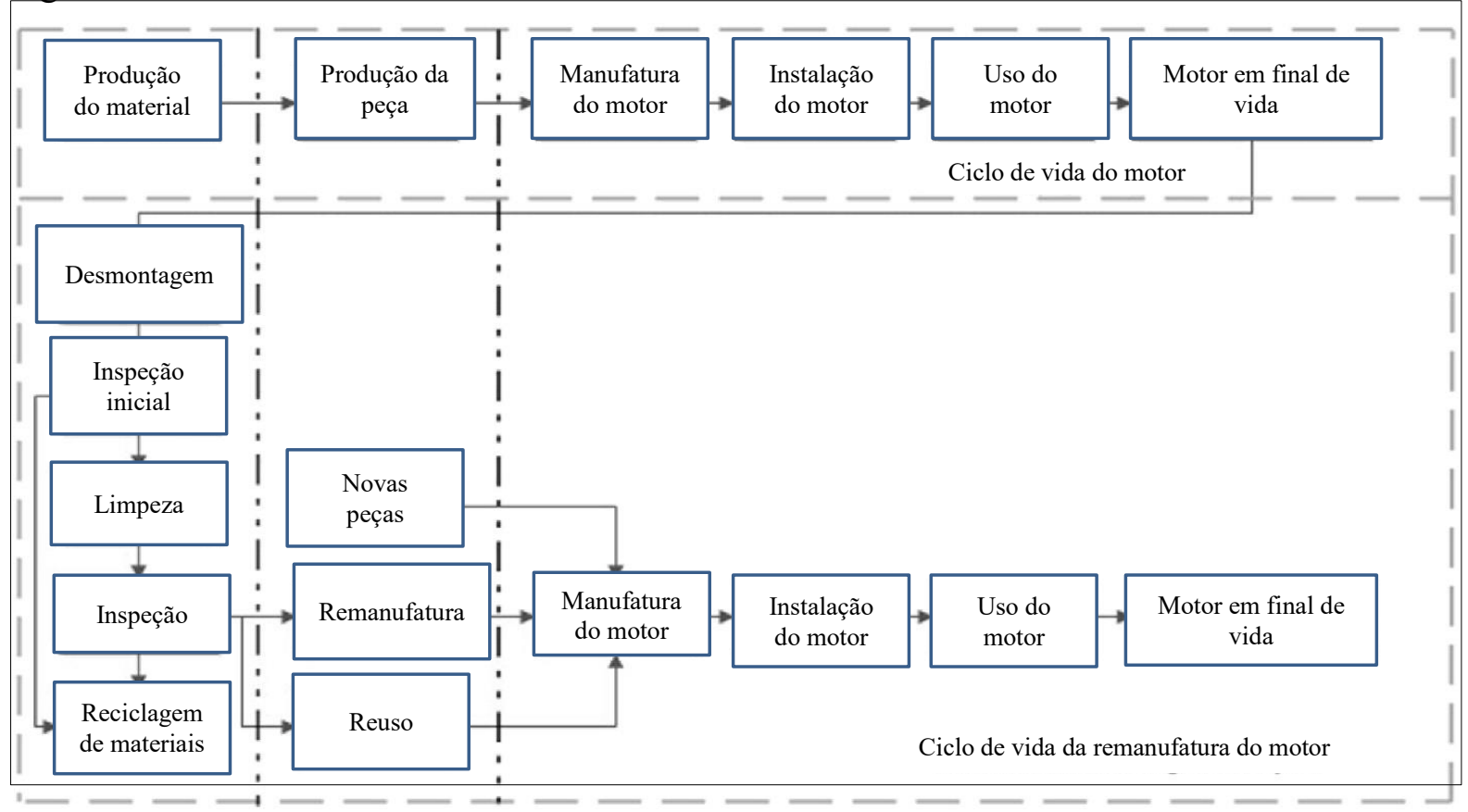

Fonte: Zhang e Chen, 2015, p.177.

Utilizando o conceito de ciclo de vida dentro da indústria automotiva, foi apresentado um estudo de caso utilizando uma abordagem qualitativa, para analisar a gestão do fim de vida do produto de uma fabricante de componentes de automóveis. Tendo em vista a circularidade de materiais na Economia Circular, o objetivo do estudo foi verificar quais as possibilidades de melhora na gestão de componentes em final de vida. Considerando quatro fases do ciclo de vida, e utilizando visitas em plantas produtivas, entrevistas e análises documentais, foram apresentados como resultados apontamentos para cada uma dessas fases, e duas oportunidades para a melhora das atividades de gestão de fim de vida dos componentes mecânicos (DIENER;

TILLMAN, 2016).

Quadro 8 - Resultados encontrados sobre a remanufatura de componentes mecânicos.

\begin{tabular}{|l|l|}
\hline Fase do ciclo de vida & Resultados encontrados \\
\hline & - Alguns materiais, quando misturados, tornaram-se inúteis em termos de \\
reciclabilidade, ou seja, a prática da reciclagem para eles se tornou não funcional; \\
- Componentes cada vez mais complexos proporcionaram maior desempenho e maior \\
durabilidade, mas, ao mesmo tempo, tornaram a reciclagem mais difícil e a \\
remanufatura praticamente impossível; \\
- A desmontagem e a remanufatura de muitos componentes mais novos e recém- \\
projetados não são possíveis sem danificá-los, considerando a quantidade de material \\
mesclado.
\end{tabular}


Conclusão

\begin{tabular}{|l|l|}
\hline \multirow{3}{*}{ Uso e substituição } & $\begin{array}{l}\text { - A quantidade de componentes substituídos durante a fase de uso do produto é similar } \\
\text { à quantidade para veículos em final de vida; } \\
\text { - Clientes, principalmente de caminhões, compram grandes quantidades de } \\
\text { componentes. Considerando que tal público utiliza centros de manutenção } \\
\text { especializados e separados de outros tipos de veículos, esforços para coletar os } \\
\text { materiais substituídos e estudos sobre esse potencial são recomendados. }\end{array}$ \\
\hline Remanufatura & $\begin{array}{l}\text { - Dependendo das práticas adotadas, os componentes, como por exemplo da caixa de } \\
\text { câmbio, são substituídos durante a remanufatura em quantidades variáveis de } 1 \text { até } \\
\text { quase } 100 \% \text {. Esta variabilidade indica uma oportunidade para aumentar o controle de } \\
\text { qualidade ou o volume de reutilização, durante o processo da remanufatura. }\end{array}$ \\
\hline $\begin{array}{l}\text { Manuseio de material } \\
\text { sucateado }\end{array}$ & $\begin{array}{l}\text { - Os componentes mecânicos dos automóveis possuem elementos que os tornam mais } \\
\text { valiosos do que a sucata normal proveniente de outras fontes. }\end{array}$ \\
\hline
\end{tabular}

Fonte: Diener e Tillman, 2016, p.48.

Em relação às duas oportunidades mencionadas pelos autores, a primeira é estabelecer parcerias com empresas de remanufatura para decidir quais componentes devem ser substituídos, em razão da sua grande variedade, principalmente em caixas de câmbio, melhorando assim o controle de qualidade do produto remanufaturado. A segunda oportunidade, pelo fato de a obsolescência ocorrer não apenas no final da vida útil do produto, mas também durante as manutenções ainda no período de uso, é desenvolver componentes aptos a serem remanufaturados ou reutilizados em qualquer etapa do ciclo de vida; em caso de impossibilidade destas soluções, estabelecer um plano de coleta dedicado ao processo de reciclagem (DIENER; TILLMAN, 2016).

\section{d) Reciclagem}

Reciclagem é o processo de transformação de resíduos em insumos ou novos produtos, e envolve a alteração de suas propriedades físicas, físico-químicas ou biológicas, por meio de um processamento (BRASIL, 2010) que reintegra materiais em determinados processos produtivos, de forma a economizar matéria-prima e energia (CAMPOS et al., 2009). Para que seja viável, a composição ou qualidade do material a ser reciclado deve ser compatível com os requisitos de sua aplicação futura (NOCI, 1995), que pode ser em circuitos abertos ou fechados. A reciclagem em circuito fechado é um processo em que o material reciclado assume a mesma função, como, por exemplo, um polímero de embalagem que voltará a ser injetado para a criação de novas embalagens. Na reciclagem em circuito aberto, o produto resultante assume novas funções como, por exemplo, caixas de madeira que são trituradas para a criação de biomassa (THORMARK, 2002).

A reciclagem em que o material resultante possui qualidade inferior ao anterior e com menor valor agregado é chamada Downcycling. A reciclagem da lata de alumínio é um 
exemplo, pois sua composição possui, além do alumínio, magnésio e tintas, resultando da reciclagem um subproduto com menor resistência e utilidade. Em contrapartida, Upcycling é o processo em que o material reciclado gera outro material de maior qualidade e valor agregado (ALI; KHAIRUDDIN; ABIDIN, 2013). Como exemplo, é possível citar a transformação de fibras alimentares em embalagens (LELLIS FERREIRA; FARIAS FILHO; QUELHAS, 2016).

O processo de reciclagem pode ser primário, secundário, terciário ou quaternário. No caso do plástico, por exemplo, que não é um material biodegradável e possui uma demanda de crescimento contínuo, a reciclagem primária é o aproveitamento do refugo plástico dentro do processo produtivo da própria empresa; a reciclagem secundária, ou mecânica, é a transformação dos resíduos de plástico em grânulos para a produção de novos produtos; a reciclagem terciária, ou química, é o reprocessamento do plástico para o desenvolvimento de novos produtos químicos; e a quaternária, ou energética, é a transformação do resíduo plástico em energia ou combustíveis (FRANCHETTI; MARCONATO, 2003). A Figura 10 apresenta uma aplicação da reciclagem química, mecânica e energética do plástico.

Figura 7 - Exemplo de reciclagem química, mecânica e energética para o plástico.

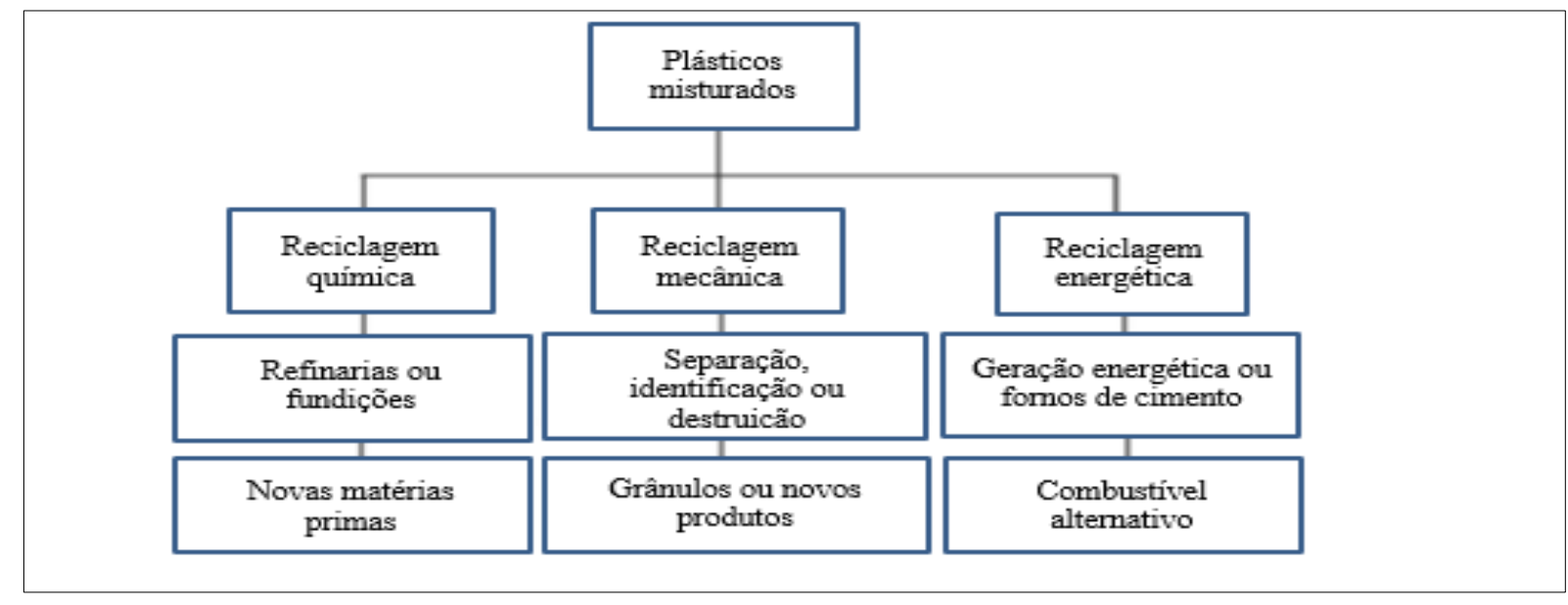

Fonte: Kang e Schoenung, 2005, p.368.

No caso, a reciclagem química seria o uso de resíduos plásticos como matérias-primas para processos petroquímicos, ou como redutores em uma fundição de metal; a reciclagem mecânica seria um processo de trituração e identificação para eventual inserção em novos produtos; e a reciclagem energética, ou térmica, seria o uso dos resíduos como combustível alternativo (KANG; SCHOENUNG, 2005).

Em relação ao processo de reciclagem na indústria automotiva, nos EUA, já no ano de 1999, 95\% dos carros e caminhões que atingiam o final da vida, anualmente, eram destinados 
às companhias de reciclagem e, para cada um desses veículos, $75 \%$ do peso foi recuperado para retornar a processos produtivos. No caso dos países da União Europeia, em razão da diretiva End Of Life Vehicle, que trata da gestão de veículos em fim de vida, países membros passaram a recuperar, por meio da reciclagem, 85\% de veículos, em média, até 2006, tendo este percentual aumentado para 95\%, em 2015. Entretanto, considerando o reuso e a remanufatura, a reciclagem é a última opção para tratamento de veículos em final de vida, em que os materiais das peças são processados e recuperados, podendo ser utilizados tanto em ciclos de produção internos quanto externos (AMELIA et al., 2009).

Para estudar a aplicação da reciclagem como um meio de Economia Circular no segmento automotivo, estudos de caso têm sido realizados de forma a contextualizar a importância do tema na gestão de materiais em final de vida, e na sua reciclabilidade, o que reduz os impactos ambientais e aumenta o retorno econômico.

Considerando a importância da reciclagem de peças de veículos em final de vida para a Economia Circular, foi realizado um estudo de caso com análise econômica da reciclagem de sistemas elétricos incorporados em veículos que estão no final da vida útil. Apesar de os veículos em final de vida e os resíduos de equipamentos elétricos e eletrônicos serem reconhecidos como fontes de matérias-primas secundárias, a gestão de sistemas eletrônicos incorporados a estes veículos raramente é considerada pela literatura científica, sendo esta uma lacuna que incentivou o tema da pesquisa. Para preenchê-la, foi proposto um modelo econômico inovador, capaz de identificar a presença de rentabilidade dentro do processo de recuperação de placas de circuitos de resíduos automotivos. Como resultado, foi evidenciada uma alta rentabilidade no processo de reciclagem dos equipamentos elétricos e eletrônicos, principalmente devido à presença de ouro nas peças; considerando o volume de resíduos gerados e o que é reciclado, ainda há um vasto mercado para tal prática. Como complemento desta pesquisa, foi sugerido um futuro estudo envolvendo questões de reciclagem destes materiais em veículos híbridos, totalmente elétricos ou, ainda, autoguiados (CUCCHIELLA et al., 2016).

Para estudar a eficiência de materiais no setor de manufatura, em termos de potencial de reciclagem, foi realizado um estudo sobre a importância desta eficiência na Economia Circular, tendo como objetivo investigar oportunidades de melhoria, e identificar as barreiras e possíveis estratégias no setor. Como unidades de análise, foram utilizadas empresas localizadas na Suécia. Por meio de coleta de dados, entrevistas, observações e análise de documentos, o autor concluiu que, quanto mais homogêneo e de alta qualidade é o material, maior a sua reciclabilidade. Em relação às barreiras para promover a eficiência dos materiais em termos de 
reciclagem, foram estabelecidas seis categorias: tecnológicas, como dificuldades em termos de engenharia ou limitações de maquinário; econômicas, como falta de investimento ou alto custo de coleta e segregação; organizacionais, como falta de consciência por parte da alta administração da empresa; legais, como falta de relação clara entre legislação e atividades na prática; informativas, como comunicações falhas em termos de conscientização e viabilidade das atividades; e, por fim, sociais, como falta de demanda de determinado mercado devido à falta de percepção dos benefícios da reciclabilidade dos materiais. $\mathrm{O}$ resultado mostrou que, com o estabelecimento de tais categorias, as companhias terão condições de eliminar as barreiras, de forma a direcionar os recursos conforme a situação em que se encontram (SHAHBAZI et al., 2016).

A reciclagem de plástico melhora a eficiência dos recursos e faz parte do contexto da Economia Circular. Com uma abordagem qualitativa para analisar as características dos materiais que estão sendo reciclados, e considerando a Convenção de Estocolmo, que proíbe produtos químicos tóxicos na sua lista de poluentes orgânicos, foi realizado um estudo do produto químico éter difenílico bromado, utilizado como retardador de chamas e recéminserido nesta lista de substâncias proibidas, além de ser um produto encontrado, em altas concentrações, em certos materiais plásticos destinados ao mercado de reciclagem. Como metodologia, o estudo foi dividido em três etapas: a primeira analisou como veículos em final de vida e resíduos de produtos elétricos e eletrônicos que podem conter a substância proibida são selecionados, separados e dispostos, podendo ir para reciclagem, aterros, incineração ou ainda exportação para outros países; a segunda etapa foi uma coleta de amostras de materiais nos fluxos de resíduos identificados na etapa anterior; a terceira e última etapa fez uma análise das amostras para verificar a composição presente. Como resultado, foram encontradas amostras do éter difenílico bromado, principalmente, em produtos utilizados em escritório, como scanners, e peças de automóveis antigos, como por exemplo o assento de um carro fabricado em 1997. Tal estudo mostra a importância de delimitações entre segurança do consumidor, redução de impactos ambientais e eficiências de recursos, devendo haver uma maior preocupação em manter produtos perigosos fora dos fluxos de reciclagem de resíduos (LESLIE et al., 2016).

Ainda com enfoque em reciclagem, um estudo de caso qualitativo analisou as portas de veículos na Austrália para verificar a aplicação da Economia Circular no país. Para isso, foram utilizadas práticas de avaliação do ciclo de vida para, além de analisar a porta em si, detalhar o fluxo do automóvel a partir do descarte do último dono, até o processo de reciclagem ou o aterro (SOO; COMPSTON; DOOLAN, 2016). 
Figura 8 - Fluxo de destinação de um automóvei em final de vida na Austrália.

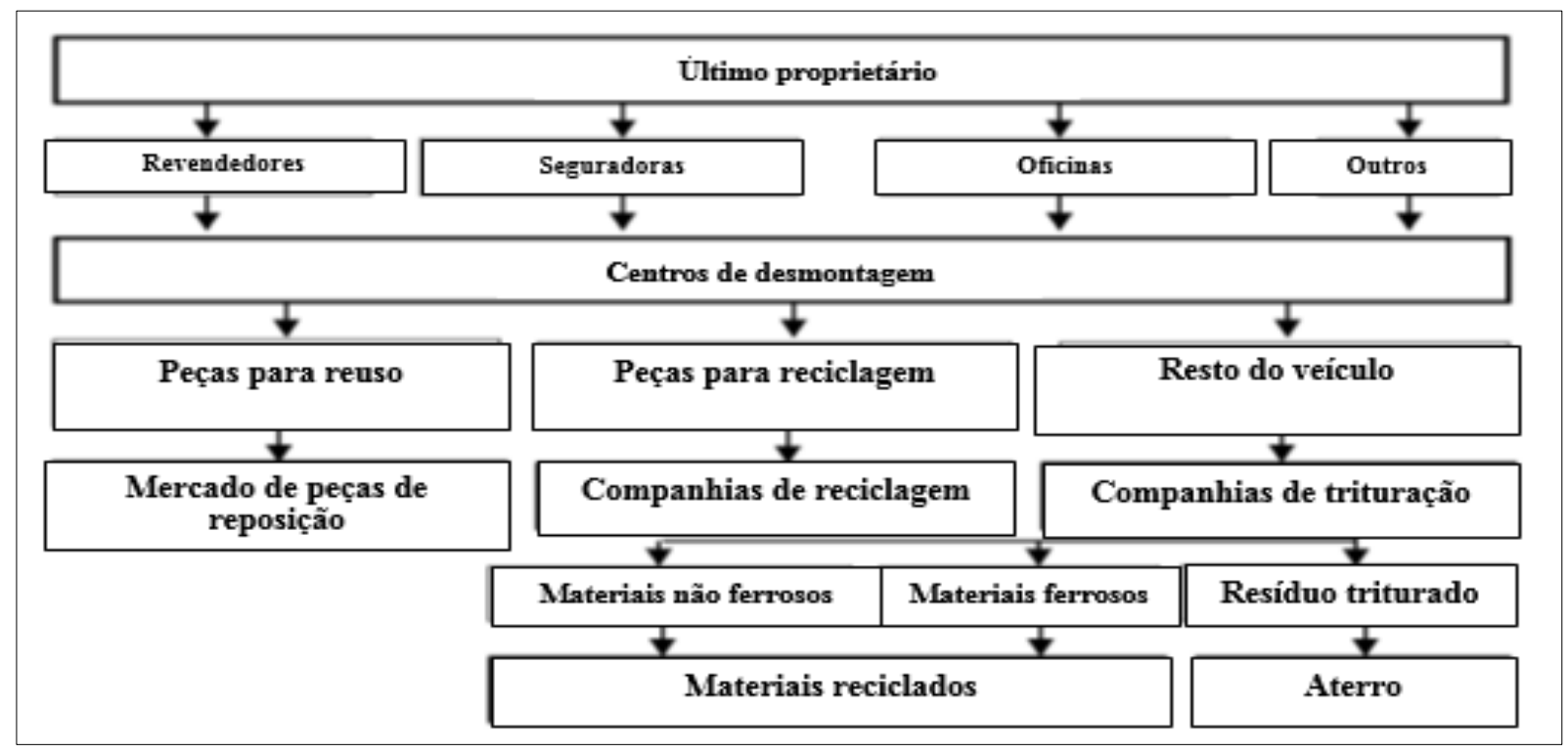

Fonte: Soo, Compston e Doolan, 2016, p.10.

A conclusão do estudo foi que, para alcançar uma Economia Circular na indústria de veículos em nível global, uma avaliação ambiental mais holística precisa ser realizada, reunindo os diversos elementos que influenciam a cadeia de valor. A presença de impurezas nos fluxos dos materiais para reciclagem precisa ser considerada, para melhorar o potencial de reciclabilidade, bem como a qualidade do reciclado resultante. O desenvolvimento de peças cada vez mais complexas e com diferentes tipos de componentes dificulta o processo de reciclagem, chegando ao ponto de o sistema tradicional de reciclagem trabalhar com mais facilidade em portas de veículos antigos do que em portas modernas, que, apesar de possuir benefícios ambientais, como redução de peso, são compostas por materiais complexos. Sendo assim, toda a concepção do produto precisa ser considerada, possibilitando uma circularidade com viabilidade econômica e com menor impacto ambiental (SOO; COMPSTON; DOOLAN, 2016).

Quadro 9 - Quadro síntese do princípio 2 da Economia Circular.

\begin{tabular}{|l|l|l|l|}
\hline Categorias & Subcategorias & Definições & Autores utilizados \\
\hline Ciclo & Regeneração & $\begin{array}{l}\text { Ambiente se recupera pelo fato } \\
\text { de o resíduo deixar de ser um }\end{array}$ & Murray, 2002; EMF, 2015. \\
& & $\begin{array}{l}\text { descarte e passar a ser um } \\
\text { nutriente, absorvido pelo próprio } \\
\text { meio para seu benefício. }\end{array}$ & \\
& & & \\
\hline
\end{tabular}


Conclusão

\begin{tabular}{|c|c|c|c|}
\hline & $\begin{array}{l}\text { Aproveitamento } \\
\text { em cascata }\end{array}$ & $\begin{array}{l}\text { Materiais são retornados ao } \\
\text { sistema e utilizados para } \\
\text { diferentes finalidades. }\end{array}$ & Redfield, 1958; EMF, 2015. \\
\hline \multirow[t]{4}{*}{$\begin{array}{l}\text { Ciclo } \\
\text { técnico }\end{array}$} & Manutenção & $\begin{array}{l}\text { É a primeira opção no tratamento } \\
\text { de produtos em fim de vida pois, } \\
\text { além de não exigir processos } \\
\text { produtivos robustos, não sai do } \\
\text { ciclo do usuário, ou seja, seu } \\
\text { fluxo ocorre entre as pessoas que } \\
\text { utilizam o material. }\end{array}$ & $\begin{array}{l}\text { ABNT, 1994; Bevilacqua; Braglia, 2000; } \\
\text { EMF, 2015. }\end{array}$ \\
\hline & $\begin{array}{l}\text { Reuso e } \\
\text { redistribuição. }\end{array}$ & $\begin{array}{l}\text { Não demandam processos } \\
\text { produtivos robustos e, apesar de } \\
\text { o novo produto ser usado para os } \\
\text { mesmos fins que o produto } \\
\text { original, há uma tendência de } \\
\text { perda de parte de seu valor } \\
\text { agregado, e a circularidade pode } \\
\text { ocorrer entre usuários não } \\
\text { próximos ou entre um usuário e } \\
\text { um prestador de serviços. }\end{array}$ & 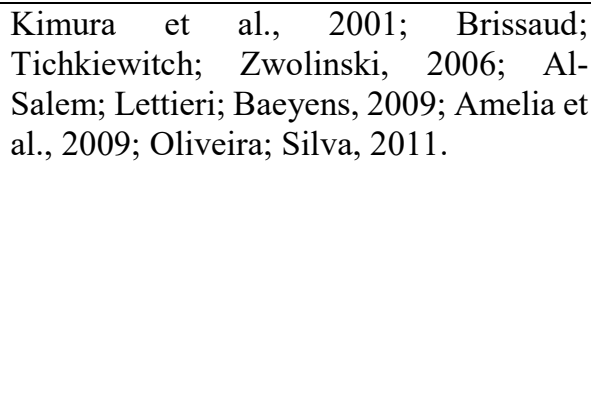 \\
\hline & Remanufatura. & $\begin{array}{l}\text { Exige um processo produtivo } \\
\text { mais robusto em que o produto é } \\
\text { renovado e seu ciclo de uso é } \\
\text { aumentado. }\end{array}$ & $\begin{array}{l}\text { Luind, 1983; Jayaraman; Guide Jr; } \\
\text { Srivastava, 1999; Guide, 2000; Keer; } \\
\text { Ryan, 2001; Savaskan; ; Bhattacharya; } \\
\text { Van Wassenhove, 2004; Brissaud; } \\
\text { Tichkiewitch; Zwolinski, 2006; Atasu et } \\
\text { al., 2008; Amelia et al., 2009; Zhang et } \\
\text { al., 2011; Agrawal; Atasu; Van Ittersum, } \\
\text { 2015; Zhang; Chen, 2015; Diener; } \\
\text { Tillman, 2015. }\end{array}$ \\
\hline & Reciclagem. & $\begin{array}{l}\text { É a última opção para tratamento } \\
\text { de produtos em fim de vida pois, } \\
\text { além de trazer uma depreciação } \\
\text { na composição dos materiais, } \\
\text { exige processos produtivos } \\
\text { robustos, se comparada ao reuso } \\
\text { e à manutenção. }\end{array}$ & $\begin{array}{l}\text { NOCI, 1995; Thormark, 2002; Franchetti; } \\
\text { Marconato, 2003; Kang; Schoenung, } \\
\text { 2005; Amelia et al.; 2009; Brasil, 2010; } \\
\text { Campos et al., 2009; Ali et al., 2013; } \\
\text { Cucchiella et al., 2016; Lellis Ferreira; } \\
\text { Farias Filho; Quelhas, 2016; Leslie et al., } \\
\text { 2016; Shahbazi et al., 2016; So; } \\
\text { Compston; Doolan, 2016. }\end{array}$ \\
\hline
\end{tabular}

Fonte: Autor

Enquanto a categoria do ciclo biológico possui como subcategorias a regeneração e o aproveitamento em cascata dos nutrientes, a categoria do ciclo técnico possui como subcategorias os tratamentos para os materiais em final de vida, que são a manutenção e o compartilhamento, o reuso e a redistribuição, a remanufatura e, por fim, a reciclagem (EMF, 2015).

\subsubsection{Princípio 3: minimização de perdas e externalidades negativas.}

A externalidade é "um custo ou benefício decorrente de qualquer atividade, que não recai sobre a pessoa ou organização que exerce a atividade" (BLACK, 1997, p.169). Como a 
externalidade pode ser um custo ou um benefício, pode-se dizer que ela é positiva ou negativa. As positivas são as que têm um efeito benéfico sobre outros indivíduos, como o impacto da vacinação de uma pessoa, que estará protegida de determinada doença, não a transmitindo para outras pessoas do entorno. Externalidades negativas, como a fumaça de uma indústria para a saúde e o meio ambiente, são as que trazem efeitos prejudiciais a outros indivíduos (DEAN; MCMULLEN, 2007).

Apesar de existirem meios para gerir externalidades negativas, como a taxação pigouviana, que busca a internalização com a aplicação, por parte do governo, de taxas com base no custo marginal social (PIGOU, 1932), e o teorema de Coase, que considera a externalidade uma mera falha de definição de direito de propriedade (COASE, 1960), o princípio 3 da Economia Circular objetiva "estimular a efetividade do sistema revelando e excluindo as externalidades negativas desde o princípio" (EMF, 2015, p.8).

Quadro 10 - Quadro síntese do princípio 3 da Economia Circular.

\begin{tabular}{|c|c|c|c|}
\hline Categorias & Subcategorias & Definições & Autores utilizados \\
\hline \multirow[t]{2}{*}{ Externalidades } & $\begin{array}{l}\text { Externalidades } \\
\text { positivas }\end{array}$ & $\begin{array}{l}\text { São benefícios decorrentes de qualquer atividade, } \\
\text { que não recaem sobre quem a está exercendo. A } \\
\text { vacinação de uma pessoa, impedindo a disseminação } \\
\text { de determinada doença, é um exemplo de } \\
\text { externalidade positiva. }\end{array}$ & $\begin{array}{l}\text { Black, 1997; Dean; } \\
\text { McMullen, } 2007 .\end{array}$ \\
\hline & $\begin{array}{l}\text { Externalidades } \\
\text { negativas }\end{array}$ & $\begin{array}{l}\text { São prejuízos decorrentes de qualquer atividade que } \\
\text { não recaem sobre quem a está exercendo. A fumaça } \\
\text { de uma indústria, causando problemas de saúde na } \\
\text { comunidade de seu entorno, é um exemplo de } \\
\text { externalidade negativa. Apesar de haver maneiras } \\
\text { para gerir tais eventos, como a taxação pigouviana } \\
\text { ou o teorema de Coase, a Economia Circular busca } \\
\text { promover a efetividade do sistema, revelando e } \\
\text { eliminando as externalidades negativas. }\end{array}$ & $\begin{array}{l}\text { Pigou, 1932; Coase, } \\
\text { 1960; Black, 1997; } \\
\text { Dean; McMullen, } \\
\text { 2007; EMF, 2015. }\end{array}$ \\
\hline
\end{tabular}

Fonte: Autor

Estão no contexto do princípio 3, desde a redução de danos provenientes de mobilidade e alimentos, dentre outros, até a gestão de externalidades envolvendo uso de terra, ar, água, poluição sonora e liberação de tóxicos (EMF, 2015).

\subsection{APLICAÇÃO DO MODELO DE ECONOMIA CIRCULAR}

Por meio de entrevistas com especialistas e análises de diversos estudos de caso, foram identificadas seis ações que empresas e governos podem adotar para iniciar um processo de transição para a Economia Circular, que são: regenerar, compartilhar, otimizar, circular, virtualizar e trocar (LEWANDOWSKI, 2016). Tais ações formam uma estrutura chamada 
ReSOLVE. Nesta estrutura, o "Re" quer dizer regenerar, que significa mudar para um modelo que utilize energias e materiais renováveis, possibilitando o retorno de recursos biológicos para a biosfera e recuperando a saúde dos ecossistemas. $\mathrm{O}$ "S" trata de compartilhar, do inglês share, e busca a máxima utilização de produtos por meio do compartilhamento entre usuários. Ainda neste contexto, compartilhar pode incluir a reutilização de produtos quando viáveis tecnicamente, graças às atividades de manutenção e reparação, que podem aumentar sua durabilidade. A letra "O" é de otimizar, ou seja, aumentar a eficiência de um produto e reduzir ao mínimo a geração de resíduos provenientes do processo produtivo e da cadeia de suprimentos. A otimização não precisa, necessariamente, de uma mudança de produto ou de tecnologia. O "L", do inglês loop, significa circular e visa manter componentes e materiais em circuitos fechados, priorizando os mais próximos como compartilhamento e manutenção, em vez de reciclagem, conforme apresentado na estrutura da Economia Circular. O "V" é de virtualizar, ou seja, buscar a desmaterialização de produto, fornecendo utilidades particulares em vez de materiais. Por fim, o "E”, do inglês exchange, trata da substituição de materiais não renováveis por outros mais avançados, por meio da aplicação de tecnologias inovadoras para o desenvolvimento de novos produtos e serviços (BALANAY; HALOG, 2016; LEWANDOWSKI, 2016).

A Economia Circular segue diferentes padrões de implantação ao redor do mundo, tanto provenientes da iniciativa privada quanto do poder público.

Em termos governamentais, na década passada, o governo chinês emitiu a lei envolvendo a Economia Circular, chamada "Lei de Promoção da Produção Mais Limpa", que entrou em vigor em janeiro de 2003. Dois anos depois, em abril de 2005, foi divulgada uma nova lei, também relacionada à Economia Circular, que é a Lei sobre Prevenção da Poluição e Controle de Resíduos Sólidos, demonstrando a preocupação do país em relação à gestão de seus resíduos sólidos (YUAN; BI; MORIGUICHI, 2006). No ano de 2008, foi criada a Lei de Promoção da Economia Circular pelo XI Congresso Popular em Pequim (MATHEWS; TANG; TAN, 2011). Assim, a implantação da Economia Circular na China é resultado da estratégia política nacional, em que o governo visa transformar não apenas a indústria, mas também a organização socioeconômica em todos os níveis, utilizando como instrumento, principalmente, o "comando e controle", que consiste em obrigações e multas em caso de descumprimento, diferentemente das políticas americanas, japonesas e europeias, que praticam a implementação por meio de incentivos de mercado (GHISELLINI; CIALANI; ULGIATI, 2016). No nível empresarial, micro ou individual, graças principalmente à Lei de Promoção da Produção Mais Limpa na China, empresas são obrigadas a realizar auditorias voltadas para a eficiência 
ambiental de processos, e encorajadas a projetar produtos mais ecológicos. No nível meso, que inclui conjuntos de empresas, o principal objetivo é desenvolver uma rede eco-industrial que beneficie tanto os sistemas de produção regionais como a proteção ambiental. Tal rede deve realizar compartilhamento de energia, infraestrutura e subprodutos, o que reduz a quantidade de resíduos descartados no meio ambiente e o consumo de recursos não renováveis. No nível macro está o desenvolvimento de eco-cidades, eco-municípios e eco-províncias. Os esforços em todos os três níveis buscam o desenvolvimento de meios para recuperar recursos, e de instalações públicas e privadas para apoiar a Economia Circular (YUAN; BI; MORIGUICHI, 2006).

Diferentemente da China, a Economia Circular na Europa está sendo implantada com uma abordagem de baixo para cima, em que diversos agentes exigem produtos ambientalmente conscientes e a adequação da legislação, tanto para a indústria quanto para órgãos do governo (GHISELLINI; CIALANI; ULGIATI, 2016). Um dos países que iniciou práticas de Economia Circular na comunidade europeia foi a Alemanha, com a publicação da lei "Closed Substance Cycle and Waste Management Act", que tem como requisito a gestão de resíduos considerando um ciclo fechado, e a garantia de uma disposição ambientalmente consciente (SU et al., 2013). Paralelamente, o conceito de Economia Circular tem sido amplamente discutido pela Comissão Europeia, o que gerou em 2014 o relatório "Towards a circular economy: a zero waste programme for Europe". Tal material coloca a Economia Circular como solução para diversos problemas envolvendo a gestão dos resíduos (COM, 2014), visando, inclusive, a conservação de matérias-primas, dentro da Estratégia Europa 2020 (PRESTON, 2012), que inclui importantes trabalhos como o Programa Nacional de Eficiência de Recursos, na Alemanha, estabelecido pelo governo para dobrar a produtividade de energia e matéria-prima até 2020, utilizando metas de redução do consumo absoluto para a conservação de recursos (LEISMANN et al., 2013); a proposta de materials roundabout da Holanda para a circularidade e o upcycling de materiais e produtos, que, levantada pelo parlamentar holandês Stientje van Veldhovez e com apoio de diversos setores, sugere que a Holanda seja um centro europeu para a reciclagem de materiais e produtos de alto desempenho (VAN DE WIEL, 2011); e estudos detalhados no Reino Unido sobre Economia Circular, conduzidos pelo grupo Green Alliance, em que são propostas normas de produtos e possíveis recompensas para a recuperação de metais (PRESTON, 2012). Em dezembro de 2015 foi oficializado pela Comissão Europeia um plano de ação para a implementação da Economia Circular, chamado Circular Economy Package. Este plano contém propostas legislativas sobre resíduos, envolvendo metas para reduzir a destinação em aterros e aumentar a reutilização e a reciclagem. Visando a circularidade, foram 
listadas ações para a gestão da cadeia de valor de produtos, que tratam da produção, consumo, reparo, gestão de resíduos e matérias-primas secundárias e, por fim, do retorno de materiais ao ciclo econômico (COM, 2017). Com a adoção das ações do pacote, espera-se, além de gerar novas oportunidades de negócios e empregos, que agentes públicos e privados em toda a União Europeia desenvolvam estratégias de investimento em longo prazo, centradas na prevenção da geração de resíduos, no reuso de produtos e na reciclagem de materiais (SHARP, 2016).

No Japão, a Economia Circular surgiu com uma ampla e estreita colaboração entre fabricantes, sociedade civil e o setor público (GHISELLINI; CIALANI; ULGIATI, 2016). Para isso, já em 2002, o governo japonês desenvolveu um quadro jurídico para incentivar a criação de uma sociedade baseada na reciclagem, publicando uma lei que fornece metas quantitativas para a reciclagem e a desmaterialização de produtos, chamada Basic Law for Establishing a Recycling-Based Society (SU et al., 2013). Um dos focos da lei é incentivar a circularidade de materiais em prol da redução de consumo de recursos naturais e da poluição ambiental, em razão dos descartes inadequados (ZHU et al., 2017).

No Brasil, a Economia Circular entrou na pauta de debates, principalmente, após a publicação dos relatórios da Fundação Ellen MacArthur. Entretanto, a circularidade de materiais já é promovida há mais tempo, por meio de legislações relacionadas à gestão de resíduos e logística reversa, que foi intensificada após a publicação da Política Nacional de Resíduos Sólidos (BRASIL, 2010). Dentre as leis e instruções normativas que promovem a logística reversa e a gestão de resíduos, estão: a Instrução Normativa Ibama ${ }^{\circ} 8$, de 30 de setembro de 2012, que institui, para fabricantes nacionais e importadores, os procedimentos relativos ao controle do recebimento e da destinação final de pilhas e baterias ou de produtos que as incorporem; a Resolução CONAMA n 362, de 23 de junho de 2005, que estabelece diretrizes para o recolhimento e destinação de óleo lubrificante usado ou contaminado; a Resolução CONAMA n ${ }^{\circ} 401$, de 4 de novembro de 2008, que estabelece os limites máximos de chumbo, cádmio e mercúrio para pilhas e baterias comercializadas no território nacional e os critérios e padrões para o seu gerenciamento ambientalmente adequado, e dá outras providências; e a Resolução CONAMA nº 416, de 30 de setembro de 2009, que dispõe sobre a prevenção à degradação ambiental causada por pneus inservíveis e sua destinação ambientalmente adequada (FEAM; FIEMG, 2016).

Práticas de Economia Circular têm sido aplicadas em diversos setores. Empresas têxteis têm realizado iniciativas por meio do reparo e reuso de roupas usadas, aplicando a reciclagem quando não houver mais condições de retornar o material ao mercado (EMF, 2016; LEITÃO, 2015). Tais iniciativas respeitam a hierarquia do ciclo técnico da Economia Circular, em que 
deve ser priorizado o reuso do material por meio de uma nova comercialização, sendo a reciclagem um meio de tratamento aplicado em último caso. Parcerias entre empresas também têm promovido a Economia Circular, e um exemplo é a utilização de tecidos de assentos usados de aviões para a confecção de bolsas, que representa um caso de Simbiose Industrial e aplica o princípio "waste is food", em que o rejeito de uma indústria pode se tornar matéria-prima de outra (HOWER, 2016).

Além de iniciativas de empresas têxteis e parcerias entre companhias, segmentos que fabricam produtos mais impactantes ambientalmente, como o de baterias, as quais possuem em sua composição materiais classificados como perigosos, buscam a aplicação de princípios econômicos circulares, avaliam o ciclo de vida de seus produtos e empregam materiais reciclados, desenvolvendo, como consequência, uma nova cadeia de suprimentos e de logística (HOWER, 2016). Estas iniciativas aplicam premissas da área de conhecimento "cradle to cradle", que considera todas as etapas do ciclo do produto, inclusive no design do projeto. Portanto, está no seu escopo o desenvolvimento do produto, a fabricação, a venda, a utilização por parte dos usuários e, no final da vida útil, a destinação de parte dos materiais para centros de reciclagem que, por sua vez, destinarão os materiais reciclados para a fabricação de novos produtos, gerando circularidade e reduzindo o consumo de matérias-primas extraídas do meio ambiente.

Em meio às iniciativas apresentadas como sustentáveis, há algumas que que não consideram todos os impactos ambientais ao longo de sua cadeia, ou mesmo ignoram as premissas da Economia Circular. Um exemplo que tem se popularizado é a utilização de PET em camisetas, que não considera o tratamento diferenciado a partir de ciclos técnicos e biológicos, apesar de parecer uma alternativa ambientalmente viável para a destinação de garrafas já utilizadas. O desenho e o material de uma garrafa PET possuem como objetivo a sua utilização como recipiente de bebidas, e, para se tornar matéria-prima de vestuário, precisa ser misturado com fios de algodão. O PET plástico possui um grande potencial de reciclagem em um ciclo técnico, enquanto o algodão é um nutriente biodegradável dentro do ciclo biológico. Quando misturados, estes materiais perdem suas propriedades, ou seja, a reciclagem do PET se torna inviável e o algodão já não é mais um nutriente biodegradável. Como resultado, o material para uma camisa de PET mostra ser um downcycling, em que ambos os materiais perdem suas qualidades iniciais, e não tem utilidade dentro dos ciclos técnicos ou biológicos, tornando-se subprodutos com circularidade inferior (TENNENBAUM, 2015).

Em relação à busca por artigos envolvendo a Economia Circular, foram encontradas diversas publicações chinesas. Isso ocorre porque, com o rápido desenvolvimento industrial e 
a alta taxa de crescimento econômico a partir da década de 1970, o país aumentou sua consciência em relação à escassez de recursos naturais e à degradação ambiental, sendo a Economia Circular considerada uma possível solução para esta problemática, o que levou à realização de diversos estudos científicos (HESHMATI, 2016).

Alguns estudos bibliométricos sobre a Economia Circular já estão sendo publicados, o que mostra o grau de discussão sobre o tema na comunidade científica. Um dos levantamentos foi feito nas bases Web of Science e ScienceDirect, que encontrou ao todo 1.031 artigos, sendo 758 com a palavra-chave "circular economy", 64 com "circular economy and cleaner production", 85 com "circular economy and eco-industrial park", 26 com "circular economy and zero waste", $11 \mathrm{com}$ as palavras "circular economy and decoupling", 2 com "circular economy and rebound effect" e, por fim, 85 artigos com as palavras "circular economy and sustainability" (GHISELLINI; CIALANI; ULGIATI, 2016). Em outro levantamento bibliométrico, em que foram considerados tópicos e publicações em inglês na Web of Science sobre "Economia Circular", foi verificado um aumento exponencial na quantidade de publicações sobre o tema. Em 2006, foram encontradas menos de 10 publicações e, no ano de 2016, este número foi maior do que 100 (GEISSDOERFER et al., 2017), estando presentes, principalmente, em um periódico que apresenta discussões e avanços sobre temas como produção mais limpa, sustentabilidade, tendências e desenvolvimento (LOZANO et al., 2016). No caso de produções científicas brasileiras que envolvem a Economia Circular, em periódicos de alto impacto, foi encontrado um estudo de caso que trata do desenvolvimento de parques eco-industriais no Rio de Janeiro. O estudo analisa duas iniciativas lançadas na cidade, e quais seus benefícios potenciais para o desenvolvimento das três dimensões da sustentabilidade, ou seja, os aspectos sociais, econômicos e ambientais (VEIGA; MAGRINI, 2009).

Em termos geográficos, provavelmente pelo fato de estar implementando o tema em âmbito nacional, a partir de ações governamentais, como a própria Lei de Promoção da Economia Circular (LIEDER; RASHID, 2016), a China é o país com a maior quantidade de publicações, apresentando um número muito superior aos de outros países (GEISSDOERFER et al., 2017). O Reino Unido, que é o segundo colocado, além de ser o local onde está a matriz da Fundação Ellen MacArthur (EMF, 2012), desenvolve iniciativas voltadas para a Economia Circular desde 2000, por meio do programa WRAP, do inglês Waste and Resource Action Programme (BONVIU, 2014). Tal programa visa o gerenciamento de resíduos por meio de projetos e conscientização pública em campanhas nacionais (TONGLET; PHILLIPS; BATES, 2004). Na terceira colocação estão os Países Baixos, onde a Holanda se propõe a ser o centro europeu para a reciclagem de produtos de alto desempenho por meio do upcycling, numa 
iniciativa conhecida como materials roundabout (VAN DE WIEL, 2011), e possui um planejamento estratégico com diversas iniciativas para a implementação da Economia Circular, tendo publicado o documento "A circular economy in the Netherlands by 2050" (IENM, 2016).

\subsection{AS CRÍTICAS AO MODELO DE ECONOMIA CIRCULAR}

Talvez por ser uma nova abordagem, se comparada às outras áreas de conhecimento, a Economia Circular é criticada por autores acadêmicos como Alan Murray e Andrea Genovese, que analisaram em detalhes suas premissas. As críticas referem-se à confusão de semântica, às consequências não intencionais e metas simplistas, à ausência da dimensão social da sustentabilidade e à impossibilidade de evitar todas as perdas, aplicando apenas a circularidade (MURRAY; SKENE; HAYNES, 2017; GENOVESE et al., 2017).

A confusão de semântica pode ocorrer com os usos de linear e circular em conjunto com a economia, já que ambas as combinações já existem, mas em contextos muito diferentes. Em 1960, o livro A Non-Communist Manifesto, de Roslow, já trazia o modelo de estágios lineares de crescimento, mas com conotações distintas da Economia Circular, descrevendo cinco estágios sucessivos pelos quais nações em desenvolvimento passam; e, quanto à circularidade, o conceito de fluxos circulares era tratado em relação à renda, produção e ciclo de despesa de consumidores e produtores (MURRAY; SKENE; HAYNES, 2017).

No caso das consequências não intencionais e metas simplistas, são dados exemplos em que atividades aparentemente sustentáveis trouxeram resultados ambientais negativos, como o caso em que uma floresta, que era habitat de diversos animais, foi transformada em uma plantação de palmeiras para o uso do óleo de palma, considerado um combustível verde, o que resultou na perda de milhões de hectares de floresta tropical, substituídos por campos de soja para a produção de biocombustíveis. Também é explicado que a simplificação excessiva é proveniente do pensamento reducionista e da modelagem matemática, em que variáveis podem ser removidas para a produção de conceitos gerenciáveis. Porém, segundo o autor, a natureza é holística, e uma meta simplista, por exemplo, é considerar que produtos com maior longevidade são sempre melhores ecologicamente, sendo que, muitas vezes, produtos biodegradáveis com menor tempo de uso podem impactar menos o meio ambiente (MURRAY; SKENE; HAYNES, 2017).

Em relação à ausência da dimensão social da sustentabilidade, não é possível concluir como o novo modelo de economia conduziria a uma igualdade social em termos de equidade, 
gênero, igualdade racial e religiosa, bem como à igualdade de oportunidades sociais (MURRAY; SKENE; HAYNES, 2017).

Sobre a Economia Circular não ser capaz de prevenir todas as perdas, apesar de poder haver circularidade de materiais, a energia que é utilizada em todas as etapas dos processos flui linearmente, transformando-se no decorrer da cadeia. A viabilidade econômica das cadeias de suprimento circulares também é questionada, pois os mecanismos para implementá-las podem ser muito frágeis. Por exemplo, processos de logística reversa podem ser custosos e inviáveis, se comparados a outros tratamentos locais para os materiais em fim de vida (GENOVESE et al., 2017).

Publicações sobre a Economia Circular esclarecem alguns pontos levantados por Alan Murray e Andrea Genovese (MURRAY; SKENE; HAYNES, 2017; GENOVESE et al., 2017). Em relação aos exemplos envolvendo consequências não intencionais e metas simplistas, a Economia Circular tem como preferência, de acordo com a hierarquia de tratamentos da Ellen MacArthur Foundation (EMF, 2015), o fluxo local de materiais, entre os próprios usuários. Em lugar de desmatamento para o plantio de árvores visando o uso de biocombustível, poderia ser utilizada a energia solar por sistemas localmente implantados. Sobre a ausência da dimensão social da sustentabilidade, sistemas circulares que privilegiam a produção de serviços tendem a trazer empregos, o que pode proporcionar um desenvolvimento social onde houver sua aplicação (MITCHELL; JAMES, 2015). Por fim, apesar de haver linearidade no fluxo de energia vinculado ao fluxo de materiais, que pode ser circular, a Economia Circular incentiva o uso de energias renováveis que, como o próprio nome diz, possuem potencial de ser restauradas pelo próprio meio ambiente no decorrer do tempo (EMF, 2015). Tais críticas, a complexidade e a novidade do tema demonstram os desafios da Economia Circular, requerendo que especialistas de diversas disciplinas, como ciências naturais, engenharia e gestão, auxiliem na resolução e esclarecimento de diversas dúvidas. Além disso, a Economia Circular enfrenta outros desafios mais práticos envolvendo, principalmente, o estabelecimento de ciclos de produção fechados. Neste caso, devem ser fornecidos incentivos para assegurar que os produtos pós-consumo sejam reintegrados ao processo de fabricação (SAUVÉ; BERNARD; SLOAN, 2016).

Apesar das críticas por parte de Alan Murray e Andrea Genovese, ambos acreditam que a Economia Circular possui diversas características positivas, sendo um modelo que necessita ser desenvolvido para que as limitações sejam minimizadas (MURRAY; SKENE; HAYNES, 2017; GENOVESE et al., 2017). Mesmo estando a Economia Circular em estágio inicial de desenvolvimento, o tema oferece um quadro confiável para melhorar radicalmente os atuais 
modelos de negócios, em direção a um desenvolvimento eco-industrial preventivo, além de possibilitar melhora do bem-estar por meio da recuperação ambiental (GHISELLINI; CIALANI; ULGIATI, 2016). No âmbito científico, resultados sugerem que a Economia Circular é um tema que possui muito espaço para melhoria, em termos de desenvolvimento conceitual e relações com outros campos, sendo um assunto distante da saturação (GEISSDOERFER et al., 2017).

Quadro 11 - Quadro síntese da Economia Circular.

\begin{tabular}{|c|c|c|c|}
\hline Categorias & Subcategorias & Elementos & Autores utilizados \\
\hline \multirow[t]{2}{*}{ Princípio 1} & \multirow{2}{*}{$\begin{array}{lr}\text { Gestão } & \text { do } \\
\text { fluxo } & \text { de } \\
\text { renováveis } & \text { e } \\
\text { de estoques } & \end{array}$} & Desmaterialização & $\begin{array}{l}\text { Ayres, 1997; Hinterberger; Schimidt-Bleed, 1999; } \\
\text { Korhonen; Wihersaari; Savolainen, 2001; Mellino et al., } \\
\text { 2014; EMF, } 2015 .\end{array}$ \\
\hline & & $\begin{array}{l}\text { Conservação do } \\
\text { capital natural }\end{array}$ & Wackernagel; Rees, 1997; Liu et al., 2010; EMF, 2015. \\
\hline \multirow[t]{6}{*}{ Princípio 2} & \multirow{2}{*}{$\begin{array}{l}\text { Ciclo } \\
\text { biológico }\end{array}$} & Regeneração & Murray, 2002; EMF, 2015. \\
\hline & & $\begin{array}{l}\text { Aproveitamento } \\
\text { em cascata }\end{array}$ & Redfield, 1958; EMF, 2015. \\
\hline & \multirow[t]{4}{*}{ Ciclo técnico } & Manutenção & ABNT, 1994; Bevilacqua; Braglia, 2000; EMF, 2015. \\
\hline & & $\begin{array}{ll}\text { Reuso } & \mathrm{e} \\
\text { redistribuição. }\end{array}$ & $\begin{array}{l}\text { Kimura et al., 2001; Brissaud; Tichkiewitch; Zwolinski, } \\
\text { 2006; Al-Salem; Lettieri; Baeyens, 2009; Amelia et } \\
\text { al., 2009; Oliveira; Silva, 2011. }\end{array}$ \\
\hline & & Remanufatura. & $\begin{array}{l}\text { Luind, 1983; Jayaraman; Guide Hr; Srivastava, 1999; } \\
\text { Guide, 2000; Keer; Ryan, 2001; Savaskan; Bhattacharya; } \\
\text { Van Wassenhove, 2004; Brissaud; Tichkiewitch; } \\
\text { Zwolinski, 2006; Atasu et al., 2008; Amelia et al., 2009; } \\
\text { Zhang et al., 2011; Agrawal; Atasu; Van Ittersum, 2015; } \\
\text { Zhang; Chen, 2015; Diener; Tillman, 2015. }\end{array}$ \\
\hline & & Reciclagem. & $\begin{array}{l}\text { NOCI, 1995; Thormark, 2002; Franchetti; Marconato, } \\
\text { 2003; Kang; Schoenung, 2005; Amelia et al.; 2009; } \\
\text { Brasil, 2010; Campos et al., 2009; Ali et al., 2013; } \\
\text { Cucchiella et al., 2016; Lellis Ferreira; Farias Filho; } \\
\text { Quelhas, 2016; Leslie et al., 2016; Shahbazi et al., 2016; } \\
\text { Soo; Compston; Doolan, 2016. }\end{array}$ \\
\hline \multirow[t]{2}{*}{ Princípio 3} & \multirow[t]{2}{*}{ Externalidades } & $\begin{array}{l}\text { Externalidade } \\
\text { positiva }\end{array}$ & Black, 1997; Dean; McMullen, 2007. \\
\hline & & $\begin{array}{l}\text { Externalidade } \\
\text { negativa }\end{array}$ & $\begin{array}{l}\text { Pigou, 1932; Coase, 1960; Black, 1997; Dean; } \\
\text { McMullen, 2007; EMF, } 2015 .\end{array}$ \\
\hline
\end{tabular}

Fonte: Autor

Pelo fato de o presente trabalho ser um estudo de caso em uma indústria fabricante de veículos comerciais, e as unidades de análise serem diversos processos que utilizam práticas de circularidade, incluindo elementos que compõem a estrutura da Economia Circular, o enfoque é dado ao ciclo técnico dos materiais. 


\section{MÉTODO DE PESQUISA}

Em razão de sua natureza, abordagem do problema, realização dos objetivos e procedimentos técnicos, o presente trabalho é uma pesquisa aplicada, qualitativa e descritiva, realizada por meio de um estudo único de caso com diferentes unidades de análise. Cada unidade de análise possui processos que trazem elementos da Economia Circular. Neste capítulo é apresentada a abordagem metodológica, os instrumentos de coleta de dados e a forma de análise e tratamento dos dados coletados.

\subsection{ABORDAGEM METODOLÓGICA}

Segundo Collis e Hussey (2005), toda pesquisa se desenvolve por meio de um processo constituído de diferentes fases, desde a formulação do problema até a apresentação e discussão dos resultados. Para obter tais resultados, deve seguir um caminho lógico para que seus objetivos sejam atingidos, podendo eles ser a revisão de algum conhecimento prévio, a explicação de novos fenômenos, o fornecimento de soluções para problemas diversos, dentre outros. Os tipos de pesquisa são definidos quanto à natureza da pesquisa, à abordagem do problema, à realização dos objetivos e aos procedimentos técnicos.

Por possuir um caráter prático, acessando teorias para um propósito específico (COLLIS; HUSSEY, 2005), a natureza desta pesquisa é aplicada. Sua abordagem é qualitativa, em razão do tipo de aproximação com o tema estudado; considerando que o conhecimento em relação ao tema é parcial e limitado, a amostra visa trazer informações aprofundadas e ilustradas, capazes de produzir novas informações (DESLAURIERS, 1991). Por ser qualitativa, são interpretados fenômenos para a atribuição de significado, focando o caráter subjetivo do objeto analisado e buscando compreender as atividades da organização, sem dar ênfase às questões numéricas. Quanto à realização dos objetivos, essa pesquisa é descritiva, o que exige o levantamento de uma séria de informações para descrever o fenômeno estudado (COLLIS; HUSSEY, 2005). O procedimento utilizado é um estudo de caso, buscando conhecer em detalhe a razão de uma determinada situação ser única e não intervir no objeto a ser estudado (YIN, 2015). Tal procedimento envolve o uso de um ou mais casos para criar uma construção teórica a partir de evidências encontradas (EISENHARDT; GRAEBNER, 2007). Seu método é dividido em três etapas, que são a definição e o projeto; a preparação, coleta e análise; e a análise final e conclusão (YIN, 2015). 
Figura 9 - Método do estudo de caso.

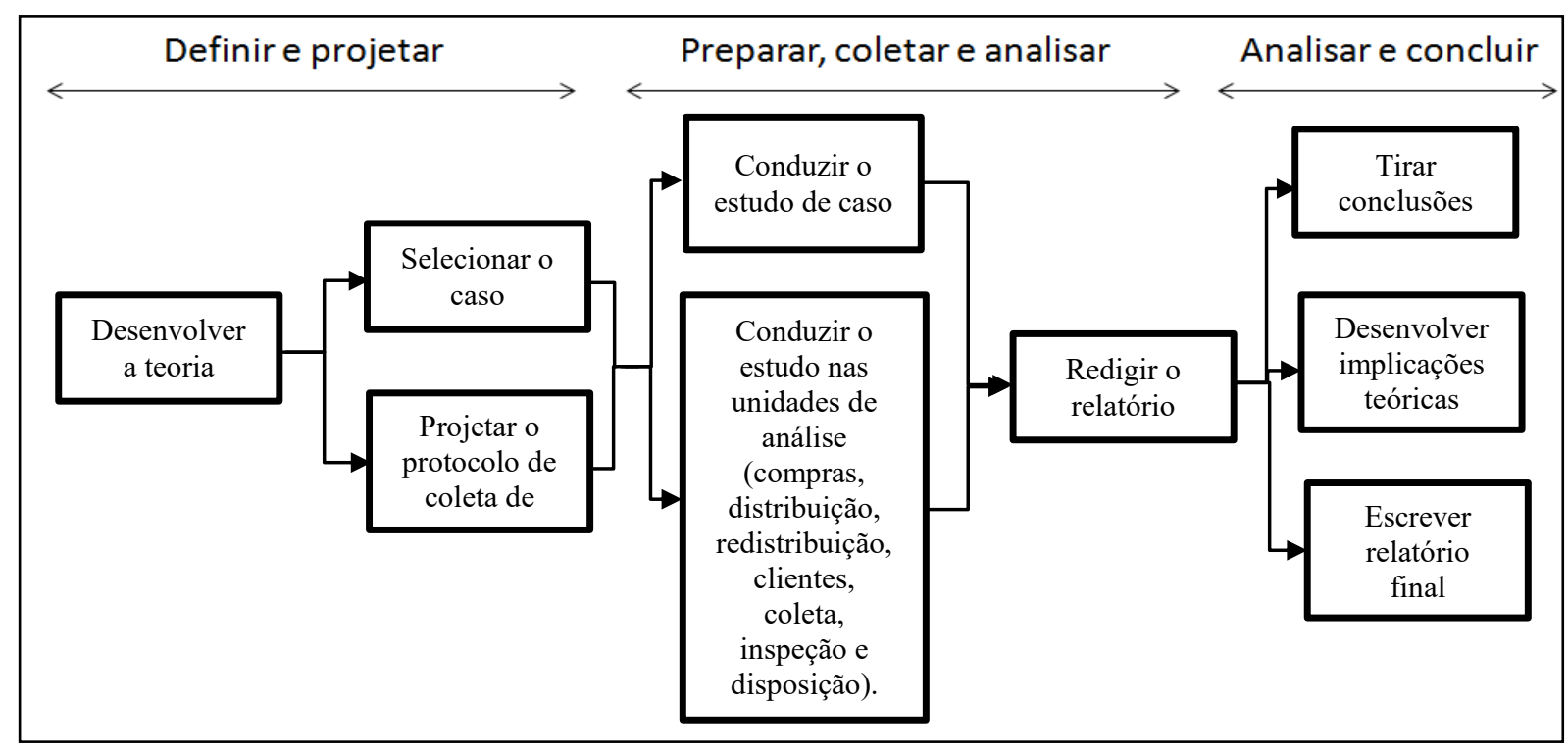

Fonte: Autor, adaptado de Yin, 2015.

Na etapa de definição e projeto, foi desenvolvida a teoria, selecionado o caso e elaborado o protocolo de coleta de dados. Em seguida, na etapa de preparação, coleta e análise, foi conduzido o estudo de caso para, na terceira etapa de análise e conclusão, possibilitar tirar conclusões sobre os casos, modificar a teoria, desenvolver implicações teóricas e escrever um relatório de casos cruzados (YIN, 2015).

\subsection{ESTUDO ÚNICO DE CASO COM DIFERENTES UNIDADES DE ANÁLISE}

O desenvolvimento de estrutura teórica como parte da fase de projeto é essencial para o estudo de caso e, para uma pesquisa descritiva, seu interesse deve ser voltado para o propósito do trabalho descritivo, a variedade de tópicos que podem ser considerados uma descrição "completa" do que está sendo estudado, e os prováveis tópicos que serão a essência da descrição (YIN, 2015).

A escolha do caso é essencial para definir as características de um projeto de pesquisa (EISENHARDT, 1989), e o presente trabalho é um estudo único de caso com diferentes unidades de análise, realizado dentro de uma indústria de veículos comerciais, com um importante papel na economia e na gestão de aspectos ambientais (ANFAVEA; CNI, 2012; ANFAVEA, 2015; FENABRAVE, 2015).

A companhia na qual foi feito o estudo de caso é uma indústria alemã de veículos comerciais, presente no Brasil desde 1956, sendo atualmente a maior fabricante de caminhões 
e chassis de ônibus da América Latina. Sua sede, em São Bernardo do Campo (SP), é a maior fábrica do grupo fora da Alemanha, além de ser a única no mundo a concentrar no mesmo local a produção de caminhões, chassis de ônibus e agregados, como motores, câmbios e eixos. Com mais três plantas no país, em Campinas (SP), Juiz de Fora (MG) e Iracemápolis (SP), a companhia oferece ao mercado brasileiro produtos e serviços para o transporte de cargas e passageiros (MB, 2016a), além de ser pioneira em processos de remanufatura entre as fabricantes de veículos no país. A planta de São Bernardo do Campo (SP), inaugurada em 1965, possui uma área total de 1 milhão de $\mathrm{m}^{2}$ e é a sede administrativa da empresa no país, além de possuir um Centro de Desenvolvimento Tecnológico, um Centro de Desenvolvimento Profissional e um Centro Tecnológico de Qualidade. A planta de Campinas (SP) é a segunda fábrica da companhia instalada no Brasil,tendo sido inaugurada em 1979. Com uma área total de $250 \mathrm{mil} \mathrm{m}^{2}$, realiza atividades voltadas para o pós-venda, como Peças \& Serviços ao Cliente, Assistência Técnica, Venda de Peças de Reposição, Central de Logística de Peças, Treinamento, Produção de Itens Remanufaturados e Central de Relacionamento com o Cliente. Juiz de Fora (MG) é a cidade com a terceira planta instalada no país, em 1999, tem uma área de 2,8 milhões de $\mathrm{m}^{2}$, e produz cabinas e caminhões, um Parque Industrial de Fornecedores e um Centro Integrado de Desenvolvimento do Trabalhador. A última planta produtiva instalada no Brasil, em 2016, fica na cidade de Iracemápolis (SP) e possui uma área de $93 \mathrm{mil} \mathrm{m}^{2}$ para a produção de automóveis. As plantas de São Bernardo do Campo, Campinas e Juiz de Fora possuem o certificado ISO 14001, e a planta de Iracemápolis está em processo de certificação. O Sistema de Gestão Ambiental (SGA) da companhia no Brasil é baseado em cinco pilares: a gestão de resíduos; a gestão de ar, água e solo; o cumprimento de conformidade legal; a busca pela ecoeficiência; e a divulgação e conscientização ambiental(MB, 2016a). Por possuir certificação ISO 14001, o SGA possui dados que podem colaborar para a busca por evidências empíricas dos princípios da Economia Circular.

No ciclo técnico da economia circular, os agentes envolvidos são os fabricantes de peças, os fabricantes de produtos e os fornecedores de serviços, que, para estabelecerem fluxos circulares, aplicam a hierarquia de tratamento de materiais. A empresa objeto do estudo de caso é, ao mesmo tempo, fabricante de peças, de produtos e prestadora de serviços.

Quadro 12 - Plantas produtivas da companhia no escopo da Economia Circular.

\begin{tabular}{|l|l|l|}
\hline Planta produtiva & Escopo na Economia Circular & Exemplos de processos que estão no escopo \\
\hline $\begin{array}{l}\text { São Bernardo do do } \\
\text { Campo }\end{array}$ & Fabricante de peças & $\begin{array}{l}\text { Produção de agregados, como eixos, câmbios e } \\
\text { motores. }\end{array}$ \\
\hline
\end{tabular}




\begin{tabular}{|c|c|c|}
\hline & Fabricante de produtos & Producão de caminhões e chassis de ônibus. \\
\hline $\begin{array}{l}\text { São Bernardo do } \\
\text { Campo }\end{array}$ & Prestador de serviços & Oficinas de manutenção. \\
\hline Campinas & Prestador de serviços & $\begin{array}{l}\text { Remanufatura, distribuição de peças e assistência } \\
\text { técnica. }\end{array}$ \\
\hline Juiz de Fora & Fabricante de produtos & Montagem de caminhões. \\
\hline Iracemápolis & Fabricante de produtos & Montagem de automóveis. \\
\hline
\end{tabular}

Fonte: Autor

A planta de São Bernardo do Campo - SP é fabricante de peças, de produtos e prestadora de serviços. São diversas as peças fabricadas, como câmbios, motores e eixos. Diferentes modelos de caminhões, além dos chassis de ônibus, são montados. Dentre os serviços prestados, estão as oficinas de automóveis. A planta de Campinas - SP se caracteriza pelos diferentes tipos de serviços prestados, como a remanufatura, a distribuição de peças e o centro de assistência técnica. A planta de Juiz de Fora - MG é responsável pela pintura de cabines e a montagem de caminhões. Por fim, a planta de Iracemápolis - SP monta os automóveis da marca.

As unidades de análise do presente trabalho estão localizadas nas plantas de São Bernardo do Campo e de Campinas..

Considerando as novas demandas do mercado e as necessidades em termos de sustentabilidade na cadeia de valor, a companhia está incrementando novos processos e modelos de negócio (MB, 2016a). Alguns desse processos e negócios, relacionados à cadeia de valor do veículo comercial caminhão, possuem elementos da economia circular e são unidades de análise do presente trabalho. Os dados foram coletados tanto nessas unidades quanto em setores que possuem relação, em termos de processos. Por exemplo, uma das unidades de análise é a Remanufatura, que é composta pela desmontagem, pelo reprocessamento e pela remontagem, e tem suporte das áreas de compras, distribuição, coleta, inspeção e seleção, disposição e, por fim, redistribuição (GOLINSKA; KAWA, 2011). Assim, dependendo das informações obtidas durante a fase de coleta de dados, esses setores também poderiam ser considerados no estudo.

Pelo fato de o estudo de caso ser relacionado ao ciclo técnico da Economia Circular, os elementos analisados são: a desmaterialização, a conservação do capital natural, a manutenção, o compartilhamento, o reuso e a redistribuição, a remanufatura, a reciclagem, a externalidade positiva e a externalidade negativa. Em razão do desdobramento de subcategorias em processos e produto caminhão, e devido ao perfil da empresa, percebeu-se a necessidade de utilização de outros termos, o que demandou uma adequação da linguagem no desenvolvimento das questões das entrevistas e na coleta de dados. 
Quadro 13 - Adequação dos elementos da Economia Circular ao estudo.

\begin{tabular}{|c|c|c|c|}
\hline Categorias & Subcategoorias & $\begin{array}{l}\text { Elementos da } \\
\text { Circular }\end{array}$ & $\begin{array}{l}\text { Elementos da Economia Circular } \\
\text { adequados ao estudo }\end{array}$ \\
\hline \multirow[t]{7}{*}{ Princípio 1} & \multirow{7}{*}{$\begin{array}{l}\text { Gestão do fluxo } \\
\text { de renováveis e } \\
\text { de estoques. }\end{array}$} & \multirow[t]{5}{*}{ Conservação do capital natural } & $\begin{array}{l}\text { Insumos renováveis e não renováveis nos } \\
\text { processos }\end{array}$ \\
\hline & & & Matéria-prima do caminhão \\
\hline & & & $\begin{array}{l}\text { Combustíveis compatíveis com o } \\
\text { caminhão }\end{array}$ \\
\hline & & & Reciclabilidade do caminhão \\
\hline & & & Desmontabilidade do caminhão \\
\hline & & \multirow[t]{2}{*}{ Desmaterialização } & Desmaterialização do caminhão \\
\hline & & & Virtualização do caminhão \\
\hline \multirow[t]{5}{*}{ Princípio 2} & \multirow[t]{5}{*}{ Ciclo técnico. } & \multirow[t]{2}{*}{ Manutenção } & Compartilhamento do caminhão \\
\hline & & & Manutenção do caminhão \\
\hline & & Reuso e redistribuição & $\begin{array}{l}\text { Reuso e redistribuição dos processos e do } \\
\text { caminhão }\end{array}$ \\
\hline & & Remanufatura & Remanufatura do caminhão \\
\hline & & Reciclagem & Reciclagem dos processos e do caminhão \\
\hline \multirow[t]{2}{*}{ Princípio 3} & \multirow[t]{2}{*}{ Externalidades } & Externalidade positiva & $\begin{array}{l}\text { Externalidade positiva dos processos e do } \\
\text { caminhão }\end{array}$ \\
\hline & & Externalidade negativa & $\begin{array}{l}\text { Externalidade negativa dos processos e do } \\
\text { caminhão }\end{array}$ \\
\hline
\end{tabular}

Fonte: Autor

A pesquisa busca, além de elencar os elementos da Economia Circular que são considerados nos processos, apresentar quais os benefícios em termos ambientais na cadeia de valor do caminhão, que é um dos produtos fabricados pela companhia estudada. As unidades de análise foram escolhidas com base em suas relações, ou com a extensão do uso do produto, ou com sua circularidade, sendo elas: o Desenvolvimento, que considera a circularidade no design do produto; a Remanufatura, que, por meio de processamentos na fábrica, possibilita a reinserção de componentes em produtos; a SelecTrucks, que recebe caminhões e faz manutenções para seu retorno ao mercado; o Programa Service24h, que realiza assistência técnica em campo; o Programa ServicePlus, que incentiva a manutenção preventiva do produto, o que aumenta o seu tempo de uso no ciclo de vida; e a Loja Virtual de peças. Processos que não possuem relação direta com a circularidade de peças e componentes, como a produção de novos caminhões, não foram considerados como unidades de análise. Dados confidenciais envolvendo aspectos comerciais ou técnicos do produto não foram utilizados no presente estudo. 


\subsection{INSTRUMENTOS DE COLETA DE DADOS}

Um estudo de caso combina diferentes métodos de coleta de dados, como entrevistas, questionários, documentos de arquivos, observações e evidências, podendo ser qualitativos, quantitativos ou mistos (EISENHARDT, 1989). As fontes de evidência utilizadas como instrumentos de coleta de dados podem ser documentações, registros em arquivos, entrevistas, a observação indireta, a observação participante e artefatos físicos (YIN, 2005).

Para definir quais fontes de evidências deveriam ser utilizadas nesse estudo, de forma a levantar os elementos da Economia Circular presentes no processo de remanufatura, foi feito um Diagrama Ishikawa, também conhecido como diagrama de causa e efeito, ou ainda espinha de peixe. Tal método é uma ferramenta qualitativa para estruturar as causas potenciais e os efeitos de determinada situação (GWIAZDA, 2006).

Figura 10 - Fontes de evidência para a coleta de dados no estudo de caso.

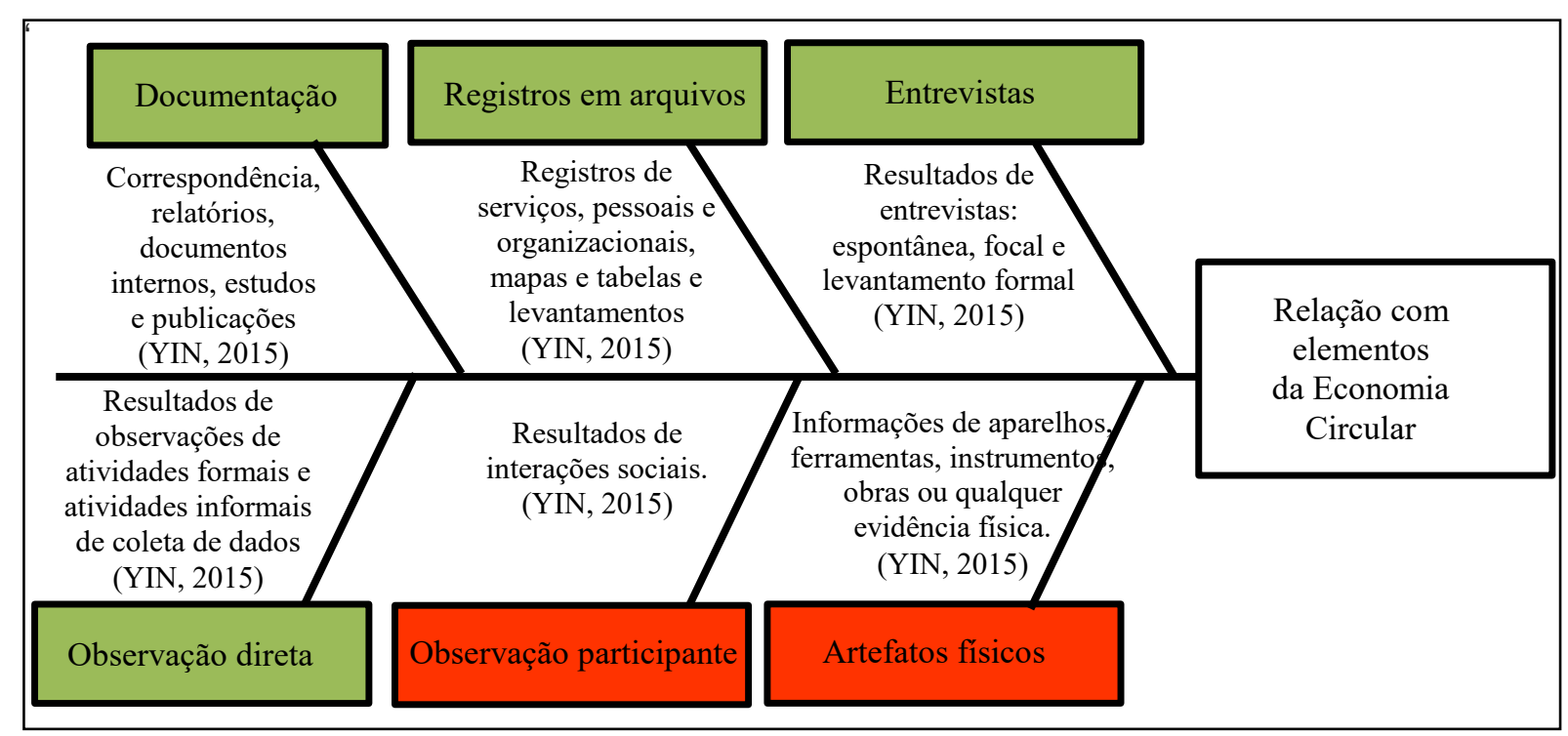

Fonte: Autor

Mesmo sendo o pesquisador um colaborador da empresa, não há uma relação direta com os processos que estão sendo estudados. Em razão da metodologia escolhida e dos objetivos propostos, que não demandam interação com o observador, manipulação de eventos ou coleta de artefatos, não foram utilizadas as fontes de evidência por observação participante e por artefatos físicos.

A pesquisa documental incluiu documentos públicos e internos da companhia (CRESWELL, 2010), e considerou correspondências, como cartas e memorandos; relatórios escritos de eventos como agendas, avisos e minutas; documentos internos, como relatórios e 
procedimentos administrativos; estudos ou avaliações formais; e, por fim, publicações em jornais, artigos e outros meios (YIN, 2015).

$\mathrm{Na}$ etapa de verificação de registros em arquivos, puderam ser encontrados e estudados: registros de serviços, como por exemplo o número de produtos atendidos em determinado período; registros organizacionais, como tabelas; registros pessoais, como anotações e diários; tabelas e mapas geográficos, listas de itens e dados provenientes de levantamentos. Esses registros continham informações quantitativas, com dados numéricos, ou qualitativas, com dados não numéricos (YIN, 2015).

As entrevistas foram semiestruturadas, pois permitem um maior entendimento do tema por meio de um roteiro com perguntas abertas, possibilitando liberdade para tratar o assunto, mas de forma direcionada (QUIVY; CAMPENHOUDT, 2008; FLICK, 2009). As questões das entrevistas utilizaram como base os elementos levantados da Economia Circular e possíveis indicadores, e são apresentadas no Apêndice B. As entrevistas ocorreram nos processos definidos como unidades de análise, e nas áreas que fornecem suporte, como por exemplo: compras, onde são gerenciados os requisitos e contatos com fornecedores; vendas e pós-vendas, que incluem relacionamento com clientes e concessionárias; e gestão ambiental, que coordena as atividades de fornecedores de tratamento de resíduos e possui indicadores ambientais que contribuem para o estudo. Foram entrevistados desde gestores dos processos até analistas administrativos e colaboradores operacionais.

Sobre as observações direta ou participante, a observação direta ocorre durante as visitas de campo, podendo variar entre atividades formais e informais de coleta de dados: as formais podem gerar protocolos de observação, estando inclusos neste formato a participação em reuniões, trabalho de fábrica e salas de aula, dentre outras atividades semelhantes; as informais podem ocorrer durante uma visita de campo em que se buscam outras evidências. Como resultado, podem ser levantadas provas observacionais, que são úteis para fornecer informações adicionais sobre o tópico de estudo. A observação participante é um método muito utilizado em estudos de etnografia, em que o observador não é passivo, podendo haver uma interação social. Essa prática oferece oportunidades, como a possibilidade de manipular eventos e participar de grupos que seriam inacessíveis à investigação científica em outras formas de coleta de dados (YIN, 2015). Como não há intenção de manipular eventos, de forma a realizar uma interação social, e sim observar as práticas dos processos, foi aplicada apenas a observação direta. Foram observados os locais de produção da remanufatura, compras, distribuição e redistribuição, que inclui principalmente as concessionárias, disposição, que são os fornecedores de tratamento dos resíduos, pátios e processos da SelecTrucks e atividades envolvendo o Programa Service24h, o 
Programa ServicePlus, e a Loja Virtual de peças. Os elementos observados foram: o recebimento, desmontagem, processamento, remontagem e saída do produto na remanufatura; manual de requisitos para fornecedores e lista dos fornecedores relacionados à remanufatura; programa de requisitos para concessionárias, metodologia de recebimento dos produtos, manutenção e guia de boas práticas para clientes nas concessionárias; processos de reciclagem e tratamento de resíduos classe 1 e classe 2 nos fornecedores de serviços ambientais; controles operacionais, tanto na Remanufatura quanto na SelecTrucks, e procedimentos e manuais do Programa Service24h, do Programa ServicePlus e da Loja Virtual de Peças. Essas informações compõem o protocolo de observação, apresentado no Apêndice C.

A sexta fonte de evidência é proveniente de artefatos físicos. Pode ser feito por meio de uma observação durante uma visita de campo, ou pela separação de algum objeto para ser estudado de forma extensiva durante a pesquisa (YIN, 2015). Como o presente trabalho estudou o funcionamento dos processos, coletando dados por meio de entrevistas, observações diretas, registros e documentos, não foi necessário coletar artefatos físicos.

Em razão das imprevistos que poderiam ocorrer, prejudicando a coleta de dados em termos de prazos, foi preciso estabelecer um procedimento em etapas para a organização das informações (YIN, 2015).

Quadro 14 - Etapas da coleta de dados.

\begin{tabular}{|c|l|l|}
\hline $\begin{array}{c}\text { Etapas da } \\
\text { coleta de dados }\end{array}$ & \multicolumn{1}{|c|}{ Procedimento } & \multicolumn{1}{|c|}{ Fonte } \\
\hline $\begin{array}{c}\text { Etapa 1: } \\
\begin{array}{c}\text { Documentação } \\
\text { e registros em } \\
\text { arquivos }\end{array}\end{array}$ & $\begin{array}{l}\text { - Levantar aspectos ambientais significativos dos processos } \\
\text { produtivos envolvendo as unidades de análise; } \\
\text { - Estudar detalhes dos processos por meio do Relatório de } \\
\text { Sustentabilidade e de procedimentos internos; } \\
\text { - Analisar os fluxos dos processos e suas relações; } \\
\text { - Estudar manuais do produto, diretivas e sistemáticas para } \\
\text { averiguar os requisitos internos e externos que promovem a } \\
\text { circularidade dos produtos por meio da logística reversa }\end{array}$ & $\begin{array}{l}\text { Correspondências, } \\
\text { relatórios, documentos } \\
\text { internos, estudos, } \\
\text { publicações, registros de } \\
\text { serviços, pessoais e } \\
\text { organizacionais, mapas, } \\
\text { tabelas e levantamentos. }\end{array}$ \\
\hline $\begin{array}{c}\text { Etapa 2: } \\
\text { Entrevistas }\end{array}$ & $\begin{array}{l}\text { - Preparar entrevista semiestruturada; } \\
\text { - Agendar entrevistas com envolvidos. }\end{array}$ & $\begin{array}{l}\text { Resultados da pesquisa } \\
\text { documental e dos registros } \\
\text { e agenda de colaboradores } \\
\text { envolvidos. }\end{array}$ \\
\hline $\begin{array}{c}\text { Etapa 3 } \\
\text { Observação } \\
\text { direta }\end{array}$ & $\begin{array}{l}\text { - Organizar datas das visitas in loco; } \\
\text { - Verificar regulamentos para a visita; }\end{array}$ & $\begin{array}{l}\text { Resultado das entrevistas, } \\
\text { planta das unidades } \\
\text { produtivas, fluxos dos } \\
\text { processos e agendas de } \\
\text { colaboradores envolvidos. }\end{array}$ \\
\hline $\begin{array}{c}\text { Etapa 4: } \\
\text { Banco de dados }\end{array}$ & Criar um banco de dados das evidências. & $\begin{array}{l}\text { Resultados das etapas } \\
\text { anteriores. }\end{array}$ \\
\hline
\end{tabular}

Fonte: Autor. 
A sequência das etapas foi estabelecida com o auxílio dos instrumentos de coleta de dados apresentados no Diagrama Ishikawa, sendo que a etapa 1 envolveu a coleta de documentos e de registros em arquivos; a etapa 2 tratou das entrevistas semiestruturadas; a etapa 3 envolveu a coleta de dados em observações; e a etapa 4 contemplou a criação de um banco de dados com as evidências coletadas nas etapas anteriores.

\subsection{FORMA DE TRATAMENTO E ANÁLISE DOS DADOS}

As evidências obtidas por meio dos instrumentos de coleta de dados seguiram três princípios para estabelecer a validade do constructo e a confiabilidade do estudo de caso. Os princípios foram: a utilização de várias fontes de evidência, a criação de um banco de dados para o estudo e o encadeamento das informações (YIN, 2015).

Por meio da utilização de várias fontes de evidência, é possível efetuar a triangulação, que pode ser de fonte de dados, triangulando os dados em si; entre os avaliadores, que considera diferentes pesquisadores; de perspectivas sobre o mesmo conjunto de dados, que triangula a teoria; e de métodos, que faz a triangulação metodológica (YIN, 2015). O presente estudo realizou apenas a triangulação de dados, utilizando diversas fontes de evidências que, quando revisadas e analisadas de forma conjunta, fez com que o estudo de caso trouxesse descobertas baseadas na convergência das informações provenientes das diferentes fontes.

Para organizar e documentar as evidências coletadas e as descobertas da triangulação, foi criado um banco de dados com as notas provenientes de entrevistas e observações. As informações contidas no banco de dados possibilitaram o encadeamento de evidências, o que trouxe maior confiabilidade das informações do estudo de caso (YIN, 2015).

O processo de análise é de grande importância para o estudo de caso (EISENHARDT, 1989) e a aplicação do método ocorre pela organização da análise, pela codificação de resultados, pelas categorizações, pelas inferências e pela informatização da análise das comunicações (BARDIN, 2011). Dessa forma, foi possível triangular as informações contidas nos documentos estudados, nos registros, nas entrevistas e nas observações. Com base nas descobertas provenientes da teoria levantada, da triangulação das informações e do modelo de delimitação, o assunto foi compreendido de forma profunda e conclusões foram extraídas. 


\section{RESULTADOS DA PESQUISA}

Nesse capítulo é explicada a estrutura de um caminhão e são apresentados os resultados da pesquisa realizada em seis unidades de análise da indústria de veículos comerciais, que são: o Desenvolvimento, a Loja Virtual de Peças, o Programa ServicePlus, o Programa Service24h, a SelecTrucks e a Remanufatura. Os resultados são provenientes de evidências obtidas em documentos, registros em arquivos, entrevistas e observações diretas.

Quadro 15 - Unidades de análise.

\begin{tabular}{|l|l|}
\hline Unidades de análise & Principal atividade \\
\hline Desenvolvimento & $\begin{array}{l}\text { Desenvolvimento de novas linhas de caminhões, chassis de ônibus e } \\
\text { realização de testes de produtos. }\end{array}$ \\
\hline Loja Virtual de Peças & Plataforma e-commerce para venda de peças e componentes. \\
\hline Programa ServicePlus & $\begin{array}{l}\text { Fornecimento de serviços de manutenções preventivas e reparos periódicos } \\
\text { dos produtos da companhia. Válido para o período de vigência da garantia, } \\
\text { que é de } 3 \text { meses em termos legais, adicionado de mais meses conforme } \\
\text { termos contratuais, podendo variar de acordo com o contrato firmado. }\end{array}$ \\
\hline Programa Service24h & $\begin{array}{l}\text { Serviço disponível para os produtos da companhia em todo o território } \\
\text { nacional, acessível 24 horas por dia, para realização de assistências e } \\
\text { manutenções corretivas. Válido para o período da garantia, assim como o } \\
\text { Programa ServicePlus. }\end{array}$ \\
\hline SelecTrcuks & $\begin{array}{l}\text { Comprar, estocar, realizar manutenções e vender caminhões seminovos de } \\
\text { diversas marcas. }\end{array}$ \\
\hline Remanufatura & Remanufaturar peças e componentes dos caminhões da companhia. \\
\hline
\end{tabular}

Fonte: Autor

As unidades de análise são processos que não possuem, necessariamente, uma estrutura física. O Desenvolvimento, a SelecTrucks e a Remanufatura possuem áreas físicas. A Loja Virtual de Peças, o Programa ServicePlus e o Programa Service24h são processos, gerenciados por departamentos da companhia. Enquanto a área de Desenvolvimento possui sua própria estrutura hierárquica, as outras unidades de análise se localizam na estrutura de negócio de pósvendas, ou seja, as atividades de serviços ao cliente após a venda do caminhão. Todas as atividades praticadas pelas unidades de análise são em âmbito nacional, de forma a atender clientes e concessionárias em qualquer estado do Brasil.

Os setores envolvidos no mercado de pós-vendas são: fabricantes de peças, distribuidores, lojas de varejo, intermediários e clientes. São considerados fabricantes de peças os de peças originais, os fornecedores de peças originais e os copistas, que são de peças não originais. Os distribuidores de peças podem ser a rede de peças originais ou distribuidoras independentes. No varejo estão concessionários, que comercializam apenas peças originais, distribuidores multimarcas, lojas independentes, oficinas de serviços, e até postos de gasolina. 
Os intermediários podem ser o mercado de componentes automotivos eletrônicos, seguradoras, locadoras, empresas de leasing e cooperativas. Os clientes são empresas, frotistas ou consumidores particulares.

Considerando os setores envolvidos no mercado de pós-vendas, a companhia objeto do estudo de caso é a fabricante de peças originais. A unidade de análise Remanufatura está situada na planta de Campinas, que é responsável por atividades de pós-vendas como, por exemplo, distribuição de peças e relacionamento com clientes e concessionários. As unidades de análise Programa ServicePlus e Programa Service24h também estão na unidade de Campinas, tendo relação direta com os concessionários. Por fim, a unidade de análise Loja Virtual de Peças possui uma plataforma criada pela companhia, que é a fabricante de peças originais. Entretanto, suas atualizações, que envolvem estoque de componentes e disponibilidade de peças, são gerenciadas pelas próprias concessionárias.

As concessionárias, apesar de não serem propriedade da empresa, possuem requisitos de processos a serem cumpridos, envolvendo desde sistemáticas de qualidade e atendimento ao cliente até controles operacionais ambientais. Esses controles envolvem a gestão de resíduos, o estabelecimento de indicadores ambientais e o cumprimento das licenças ambientais, que são disponibilizados para os concessionários por meio de um manual de requisitos.

Quadro 16 - Requisitos ambientais da companhia para as concessionárias.

\begin{tabular}{|l|l|l|}
\hline Capítulo & Tópico & Explicação do requisito \\
\hline $\begin{array}{l}\text { Descarte } \\
\text { adequado } \\
\text { resíduos }\end{array}$ & Coleta Seletiva & $\begin{array}{l}\text { A concessionária deve estabelecer uma coleta seletiva, apresentando à } \\
\text { companhia, em caso de visita de um consultor, os locais onde estão } \\
\text { dispostos os coletores. Não haverá penalização para o concessionário } \\
\text { que não aplicar a coleta seletiva, desde que evidencie a destinação } \\
\text { adequada dos resíduos. }\end{array}$ \\
\cline { 2 - 3 } & $\begin{array}{l}\text { Gerenciamento } \\
\text { de resíduos } \\
\text { sólidos }\end{array}$ & $\begin{array}{l}\text { A concessionária deve estabelecer um plano de gerenciamento de } \\
\text { resíduos sólidos, apresentando à companhia, em caso de visita de um } \\
\text { consultor, o ponto de armazenamento temporário de resíduos, qual a } \\
\text { destinação e o procedimento estabelecido para a atividade. }\end{array}$ \\
\hline Desempenho & $\begin{array}{l}\text { Indicadores } \\
\text { Ambientais }\end{array}$ & $\begin{array}{l}\text { A concessionária deve definir indicadores e metas ambientais, } \\
\text { acompanhando-os e tomando ações para o seu alcance. }\end{array}$ \\
\hline $\begin{array}{l}\text { Requisitos } \\
\text { legais }\end{array}$ & $\begin{array}{l}\text { Licença } \\
\text { ambiental }\end{array}$ & $\begin{array}{l}\text { A concessionária deve possuir a licença válida, quando não houver } \\
\text { dispensa pelo órgão ambiental, respeitando as condicionantes de } \\
\text { controle operacional presentes no documento. }\end{array}$ \\
\hline
\end{tabular}

Fonte: Autor

Além dos requisitos aos concessionários, a companhia desenvolveu uma premiação que, desde 2010, homenageia e compartilha as iniciativas que reduziram impactos ou melhoraram o desempenho ambiental das atividades das concessionárias, visando estimular iniciativas ambientais. 
As práticas das unidades de análise da companhia mostram uma estratégia de investir em atividades de serviços, considerando não apenas a produção e a venda de veículos, que é a prática tradicional no segmento, mas também o fornecimento de assistência em toda a cadeia de uso, trazendo elementos de circularidade de materiais.

\subsection{A ESTRUTURA DE UM CAMINHÃO}

Um caminhão pode ser dividido em diferentes conjuntos de componentes, conforme suas funções de aplicação. Visando organizá-los conforme a relação entre os componentes, o presente trabalho organiza os conjuntos em quatro grandes grupos, que são: o grupo 1, formado pelo motor, sistema de arrefecimento, sistema de combustível e sistema de escapamento; o grupo 2, formado pela embreagem e pedal, caixa de câmbio e transmissão; o grupo 3, formado pelos eixos, sistema de freio, cubos e rodas, suspensão e direção; e o grupo 4, formado pelo sistema elétrico, cabine e carroceria.

Quadro 17 - Conjuntos e principais peças de um caminhão.

\begin{tabular}{|c|c|c|}
\hline Grupo & Conjunto & Principais peças \\
\hline \multirow[t]{4}{*}{1} & Motor & $\begin{array}{l}\text { Cabeças do cilindro, balanceiro, tampa de válvula, blocos de cilindros, carcaça do } \\
\text { volante, carcaça do comando, cárter inferior, eixos de manivelas, volantes do motor, } \\
\text { êmbolos, buchas do cilindro, eixos de comando de válvulas, bombas de óleo, } \\
\text { radiador a óleo, depurador de óleo, filtro de óleo, varetas de medição de óleo, sensor } \\
\text { da pressão do óleo, coletor de escapamento, turbo, suspensões do motor, conjuntos } \\
\text { de vedação do motor e conjuntos de filtros }\end{array}$ \\
\hline & $\begin{array}{l}\text { Sistema de } \\
\text { arrefecimento }\end{array}$ & $\begin{array}{l}\text { Radiador, radiador do turbolader, ventilador, tensor de correias, termostato, filtro } \\
\text { da água de arrefecimento, bombas de água, mangueiras do radiador, mangueiras do } \\
\text { turbolader, tanques de expansão, válvulas de pressão, sensor de nível, polias } \\
\text { tensoras, cubos do ventilador, polias de correias e coberturas do ventilador. }\end{array}$ \\
\hline & $\begin{array}{l}\text { Sistema de } \\
\text { combustível }\end{array}$ & $\begin{array}{l}\text { Unidades injetoras, tubulações de injeção, injetores, filtro de combustível, } \\
\text { tubulações de combustível, sensor de enchimento do tanque, filtro separador de } \\
\text { água, tanques de combustível, válvulas magnéticas, torneiras de saída, bombas } \\
\text { alimentadoras, válvulas de descarga, sensores de temperatura, válvula do exaustor, } \\
\text { tampa do tanque e correias tensores. }\end{array}$ \\
\hline & $\begin{array}{l}\text { Sistema de } \\
\text { escapamento }\end{array}$ & $\begin{array}{l}\text { Silencioso, tubos de escapamento, tubos flexíveis, braçadeiras, escudos térmicos, } \\
\text { freios motor, coletor do escapamento, cilindros de operação e filtro de ar. }\end{array}$ \\
\hline \multirow[t]{3}{*}{2} & $\begin{array}{l}\text { Embreagem e } \\
\text { pedal }\end{array}$ & $\begin{array}{l}\text { Pedais da embreagem, cilindro da embreagem, discos do dispositivo de arraste, } \\
\text { conjuntos de embreagem, servos da embreagem, mancal de desengate, mangueiras } \\
\text { da embreagem, forquilhas de desengate, placas de apoio e cabos do acelerador de } \\
\text { mão }\end{array}$ \\
\hline & $\begin{array}{l}\text { Caixa } \\
\text { câmbio }\end{array}$ & $\begin{array}{l}\text { Engrenagens, eixos de acionamento, eixos principais, eixos de acoplamento, } \\
\text { dispositivo de arrastamento final, engrenagem planetária, alavanca de mudança, } \\
\text { manetes de alavanca, anéis de sincronização, unidades de sincronização, suspensões } \\
\text { da transmissão, radiador a óleo, tubulações, bombas de óleo, filtro de óleo, válvulas } \\
\text { do limite de pressão, conjunto de vedações e cilindro de mudança. }\end{array}$ \\
\hline & Transmissão & Eixos articulados, cruzetas, mancal central, flanges e pinos soldados. \\
\hline
\end{tabular}


Conclusão

\begin{tabular}{|c|c|c|}
\hline \multirow[t]{5}{*}{3} & Eixos & $\begin{array}{l}\text { Eixo dianteiro: conjuntos de pivotes de manga do eixo, tensores e cabeçotes } \\
\text { esféricos. Eixo traseiro: conjuntos da roda, eixos do satélite do diferencial, eixos de } \\
\text { acionamento, rodas planetárias, carcaça do diferencial, rolamentos, engrenagens, } \\
\text { embreagem e câmbio }\end{array}$ \\
\hline & $\begin{array}{l}\text { Sistema de } \\
\text { freio }\end{array}$ & $\begin{array}{l}\text { Tambores de freio, eixos de comando do freio, ajustador de folga, discos de freio, } \\
\text { cilindro de freio, tanques de ar, compressores, válvulas de freio, secador do ar, } \\
\text { pedais do freio, radiador a óleo, conjuntos de pastilhas de freio, tubulações do freio } \\
\text { e mangueiras do freio. }\end{array}$ \\
\hline & Cubos e rodas & $\begin{array}{l}\text { Pinos de roda, rolamentos de roda, cubos de roda, aneis de vedação do eixo, tampa } \\
\text { do cubo e porcas, além de pneus com modelos que variam conforme função do } \\
\text { caminhão. }\end{array}$ \\
\hline & Suspensão & $\begin{array}{l}\text { Feixes de molas, pinos } \mathrm{K} \text {, conjuntos de pinos de feixe de molas, amortecedores, } \\
\text { sacos de suspensão a ar, mancal de borracha, estabilizadores, travessas de reação, } \\
\text { travessas } \mathrm{V} \text {, válvulas, sensor de nível, bomba hidráulica, comutador magnético, } \\
\text { válvulas de nível e balanços da mola. }\end{array}$ \\
\hline & Direção & $\begin{array}{l}\text { Bloqueios de roda da direção, bloqueios da ignição, colunas da direção, engrenagem } \\
\text { da direção, bombas assistente de direção, tanque de óleo, filtro de óleo e mangueiras } \\
\text { da direção. }\end{array}$ \\
\hline \multirow[t]{3}{*}{4} & $\begin{array}{l}\text { Sistemas } \\
\text { elétricos }\end{array}$ & Alternador, partida, farois, luzes traseiras, pisca-piscas, interruptores e relés. \\
\hline & Cabine & $\begin{array}{l}\text { Amortecedores da cabine, sacos de ar, amortecedores de vibrações, travas da capa, } \\
\text { emissor, conjuntos de cilindro de fechamento, mancal do braço do limpador de para- } \\
\text { brisas, jatos do para-brisas, motores do limpador de para-brisas, tanque de água, } \\
\text { água para limpeza do para-brisas, buzina, estabilizadores da cabine, bomba } \\
\text { hidráulica, cilindro de basculação, filtro de ar para cabine, condensadores, válvulas } \\
\text { de regulagem, aquecedor, mangueiras, motores da ventilação, trocador de calor, } \\
\text { válvulas de nível e compressor do ar condicionado, além de bancos e camas, } \\
\text { conforme modelo do caminhão. }\end{array}$ \\
\hline & Carroceria & $\begin{array}{l}\text { Para-choques, grade frontal, portas, estribos, para-lamas, limpadores de para-brisa, } \\
\text { máquina para elevar janelas, maçanetas das portas, molas a ar, suportes dos para- } \\
\text { lamas, espelho, quebra-vento, borracha de vedação, dobradiças, manivelas para } \\
\text { elevar janelas e para-sol. }\end{array}$ \\
\hline
\end{tabular}

Fonte: Autor.

Nota: Elaborado com base em DT, 2017.

O motor é considerado o coração do caminhão, que, por meio da combustão, transforma o combustível em energia mecânica, movimentando o veículo. O sistema de arrefecimento diminui a temperatura do líquido de arrefecimento, de forma a controlar a temperatura do motor. O sistema de combustível recebe, prepara e direciona o combustível para a combustão interna, alimentando o motor. O sistema de escapamento recolhe e envia os gases produzidos para o tubo de descarga, além de reduzir o ruído do funcionamento do motor. 
Figura 11 - Ilustração do motor e dos sistemas de arrefecimento, de combustível e de escapamento.

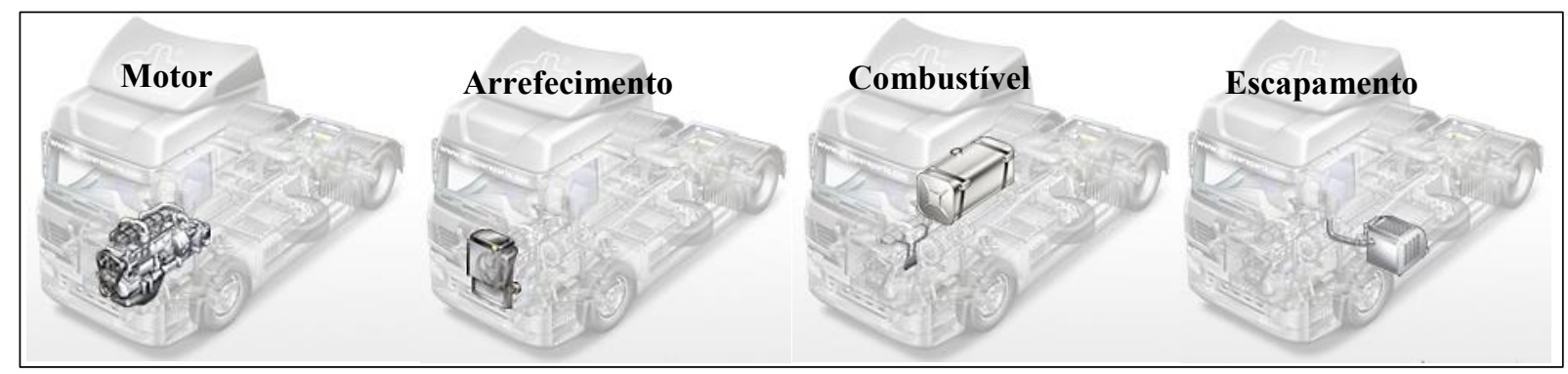

Fonte: DT, 2017.

A embreagem, por meio do acionamento do pedal, proporciona a troca de marchas. Sua função é transmitir a força do motor para a caixa de câmbio que, por sua vez, transmite essa força para outros componentes do sistema de transmissão. A força do sistema de transmissão é responsável pelo direcionamento de força, rotação e torque do motor até as rodas.

Figura 12 - Ilustração do sistema de pedal e embreagem, caixa de câmbio e transmissão.

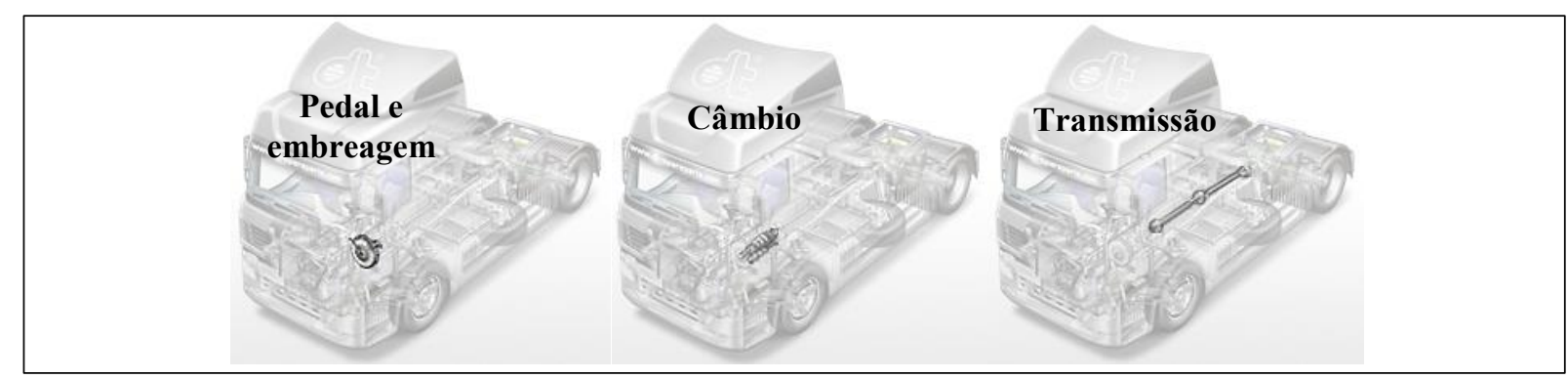

Fonte: DT, 2017.

Os eixos são a interface entre a roda e o chassi, e objetivam guiar o movimento de rotação às engrenagens e às rodas. O sistema de freio é colocado em funcionamento quando o motorista aciona o pedal de freio que, por meio de fluidos hidráulicos, gera a força necessária para o atrito e a frenagem do caminhão. $\mathrm{O}$ cubo de roda possui como função alinhar, fornecer suporte e transmitir força para as rodas. A suspensão auxilia o desempenho, absorvendo as irregularidades do solo e mantendo os pneus no chão, trazendo estabilidade ao caminhão. A direção é responsável por transmitir a movimentação do volante e da coluna de direção para a caixa de direção, que é acoplada às rodas e pneus, fazendo-os girar em seu eixo com o suporte do sistema de suspensão. 
Figura 13 - Ilustração dos eixos, do sistema de freio, do cubo e roda, da suspensão e da direção.

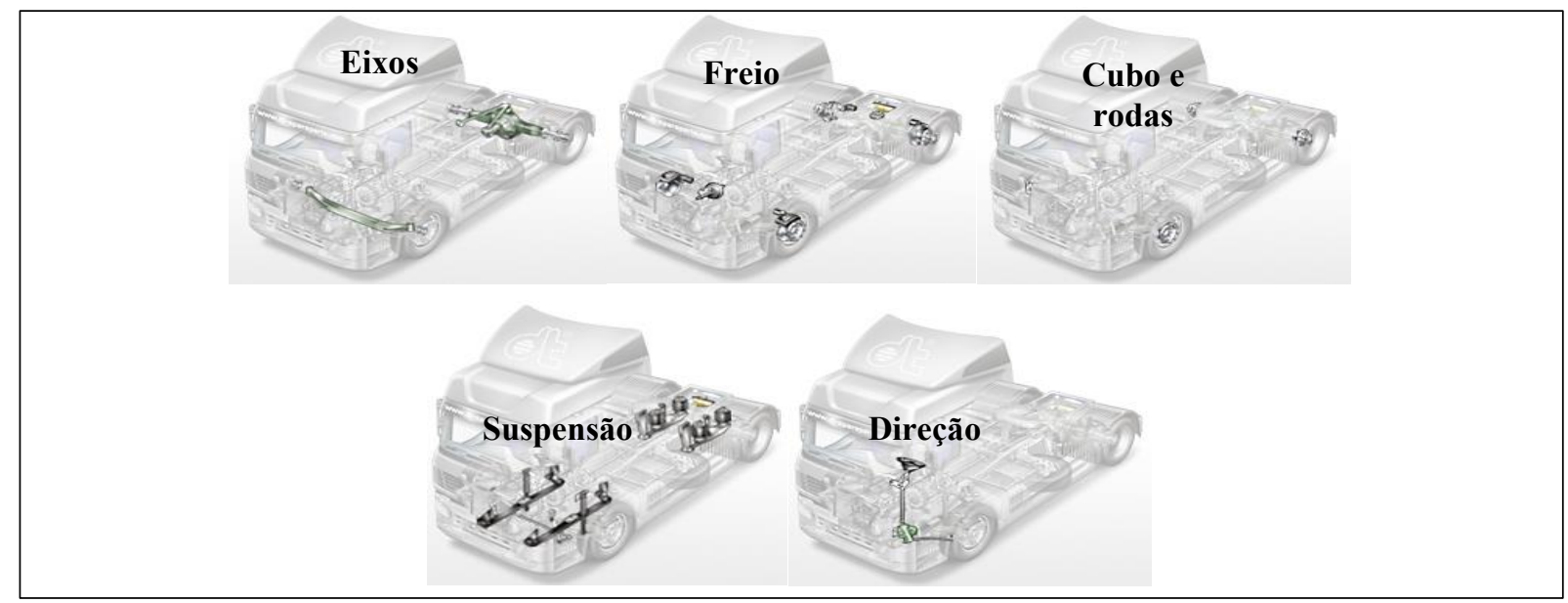

Fonte: DT, 2017.

Os sistemas elétricos são carregados com o acionamento do motor, que transforma a energia mecânica em elétrica, necessária para o carregamento da bateria e a alimentação dos componentes de ignição e os equipamentos elétricos. A cabine é o local onde o motorista fica para conduzir o caminhão. A carroceria é toda a parte externa que protege o veículo de fatores externos, como batidas ou intempéries.

Figura 14 - Ilustração dos sistemas elétricos, da cabine e da carroceria.

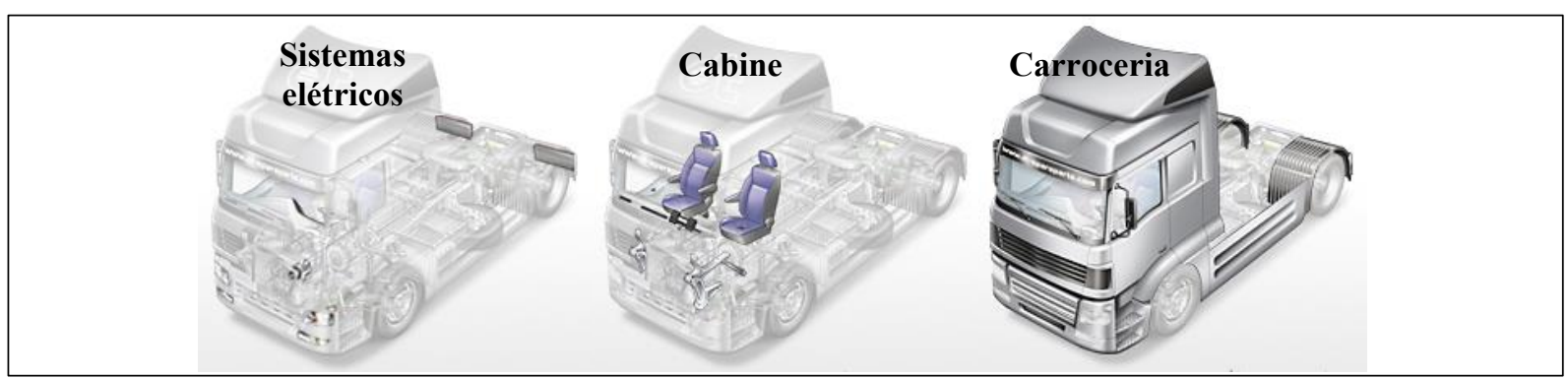

Fonte: DT, 2017.

Todos os componentes do caminhão são interdependentes, ou seja, a manutenção correta de cada peça é essencial para o funcionamento de todo o sistema. No estudo das unidades de análise, é apresentada a tratativa de pós-vendas em termos de manutenções, comercialização virtual de peças originais e remanufatura, como base de troca de peças e componentes usados, promovendo circularidade dos materiais presentes no caminhão. 


\subsection{UNIDADE DE ANÁLISE DESENVOLVIMENTO DO CAMINHÃO}

A área de Desenvolvimento de Caminhões da companhia no Brasil possui uma grande relação com a área de Desenvolvimento da matriz na Alemanha. Os projetos dos produtos são provenientes da matriz, sendo "tropicalizados" ao chegar no Brasil, sendo seus desenhos adaptados ao mercado nacional. Ainda na área de Desenvolvimento da Alemanha, há um setor responsável pelas questões ambientais dos projetos do produto. Conhecido como Design for Environment DfE, em português desenho para o meio ambiente, o setor desenvolve projetos e estuda os produtos considerando seus impactos ambientais desde o início de sua confecção, reconhecendo a relação entre os benefícios ambientais e ecológicos e buscando, principalmente, a redução de peso e a melhoria de desempenho em termos de consumo de combustível (DAG, 2006). Um exemplo de iniciativa de redução de peso é um motor denominado OM 654 que, por meio da utilização de menos materiais no design, trouxe uma redução de peso de $18 \%$ quando comparado ao mesmo componente da geração anterior, que era de $204 \mathrm{~kg}$ e passou para 168 kg. Tal redução proporciona tanto a redução de consumo de combustível do caminhão quanto de emissão de CO2 (DAG, 2016).

O grupo que trabalha com DfE possui especialistas em cinco diferentes setores, que são: Avaliação do Ciclo de Vida, Planejamento de Desmontabilidade e Reciclabilidade, Engenharia de Materiais e de Processos, Desenho e Produção. Seu objetivo é melhorar continuamente o desempenho dos produtos, para a redução de seus impactos ambientais. A separação do DfE em cinco setores se justifica pelo fato de os veículos serem produtos complexos, que interagem com o meio ambiente de maneiras também complexas, sendo preciso trabalhar em diferentes frentes para buscar soluções que tragam benefícios de forma integrada (FINKBEINER et al., 2006). Trabalhos em DfE buscam mapear os estágios do produto, levantando a relevância de cada impacto de forma a estabelecer melhorias, que podem envolver, por exemplo, o uso de materiais renováveis e recicláveis (FINKBEINER, 2001; FINKBEINER et al., 2006).

Quadro 18 - Setores do DfE da companhia na Alemanha.

\begin{tabular}{|l|l|}
\hline Setor de DfE & Atividades \\
\hline $\begin{array}{l}\text { Avaliação do } \\
\text { Ciclo de Vida }\end{array}$ & Estudos de avaliação do ciclo de vida em veículos, seguindo diretrizes da ISO 14040. \\
\hline $\begin{array}{l}\text { Planejamento de } \\
\text { Desmontabilidade } \\
\text { e Reciclabilidade }\end{array}$ & $\begin{array}{l}\text { Estudos de projeto envolvendo a desmontabilidade de componentes e a reciclabilidade de } \\
\text { materiais utilizados nos veículos. }\end{array}$ \\
\hline $\begin{array}{l}\text { Engenharia de } \\
\text { Materiais e de }\end{array}$ & $\begin{array}{l}\text { Estudos de engenharia para uso de materiais e desenvolvimento de processos } \\
\text { ambientalmente adequados. }\end{array}$ \\
\hline
\end{tabular}


Conclusão

\begin{tabular}{|l|l|}
\hline Desenho & Desenvolvimento de desenhos que considerem o desempenho ambiental dos veículos. \\
\hline Produção & $\begin{array}{l}\text { Estudos de perfis produtivos que considerem a melhoria contínua do desempenho } \\
\text { ambiental. }\end{array}$ \\
\hline
\end{tabular}

Fonte: Autor

Um dos agentes que impulsionou a criação do setor de DfE foi a diretiva europeia para veículos em final de vida que, desde sua introdução em 2000, incentivou a indústria automotiva e os fabricantes de bens duráveis em geral a considerar as questões ambientais em sua cadeia de valor, visando aumentar a recuperação dos veículos em final de vida, de forma a reduzir desperdícios e melhorar o desempenho ambiental dos produtos e processos (COM, 2000). Como resultado de trabalhos de DfE, inclusive das avaliações do ciclo de vida conforme a ISO 14040, que demonstram a evolução do desempenho do veículo ao longo de sua vida e de suas atualizações de projeto (ISO, 1997), a área de Desenvolvimento na Alemanha divulga, ao comercializar novos automóveis, Relatórios Ambientais que seguem as premissas da ISO 14062, que trata dos aspectos e impactos ambientais do produto (ISO, 2002). No entanto, pelo fato de a diretiva europeia de veículos em final de vida não ser aplicável a caminhões, os Relatórios Ambientais divulgados pela companhia são de seus carros. Com isso, apesar das iniciativas do setor de DfE em veículos comerciais, grande parte das publicações disponíveis no website da empresa, com resultados de avaliação do ciclo de vida e do desempenho ambiental dos produtos, são de carros de passeio.

No Brasil, o Centro de Desenvolvimento Tecnológico (CDT), inaugurado em 1991 e localizado num terreno com cerca de $40 \mathrm{mil} \mathrm{m}^{2}$ em São Bernardo do Campo, é o maior da América Latina e o maior do grupo fora da Alemanha para veículos comerciais. O setor de desenvolvimento é responsável por novas linhas de caminhões e chassis de ônibus, criando soluções para o transporte de cargas e de passageiros, alinhadas às necessidades dos negócios de seus clientes, além de testar combustíveis alternativos ao diesel de petróleo como, por exemplo, o diesel de cana e o biodiesel (MB, 2016b).

Para aumentar a durabilidade do produto em uso, o CDT possui um banco de provas que simula operações do veículo em condições severas, obtendo resultados de desempenho de componentes e conjuntos como, por exemplo, cabina, motor, coxins, câmbio, eixos, chassi, para-choque, tanque de combustível e painel de instrumentos (MB, 2016b).

Desde 2012, os caminhões da companhia atendem às exigências do PROCONVE (Programa de Controle de Poluição do Ar por Veículos Automotores) P7, que equivale à legislação europeia de emissões de gases e material particulado, conhecida como Euro V. Para isso, utiliza uma tecnologia denominada BlueTec5, que otimiza a combustão do motor para 
diminuir o consumo de combustível, a rejeição térmica e a emissão de material particulado, tratando os óxidos de nitrogênio (NOx) no sistema de exaustão do motor com a injeção do ARLA32. Como resultado, são reduzidas as emissões de NOx, de materiais particulados (PM), de monóxido de carbono (CO), de hidrocarbonetos totais (THC) e de fumaça, emitidas por seus motores, quando comparadas aos produtos antecessores, que respeitavam o PROCONVE P5 (Euro III) (MB, 2017c).

Quadro 19 - Comparação das emissões do PROCONVE P5 e do PROCONVE P7, conforme ciclos ESC (Ciclo Europeu em Regime Constante) e ELR (Ciclo Europeu de Resposta em Carga).

\begin{tabular}{|l|c|c|c|}
\hline \multirow{2}{*}{ Emissões } & \multicolumn{2}{|c|}{ Quantidade (g/KWh) } & \multirow{2}{*}{ Redução em \% } \\
\cline { 2 - 3 } & PROCONVE P5 & PROCONVE P7 & \\
\hline NOx & 3,2 & 2 & 37,5 \\
\hline PM & 0,036 & 0,02 & 44,4 \\
\hline CO & 1,905 & 1,5 & 21,3 \\
\hline THC & 0,598 & 0,46 & 23,1 \\
\hline Fumaça & 0,685 & 0,5 & 27,0 \\
\hline
\end{tabular}

Fonte: Autor.

Nota: Elaborado com base na Resolução CONAMA 403/2008 (BRASIL, 2008).

O ARLA32 é uma solução com 32\% de ureia, armazenado num reservatório específico do veículo e, por meio de uma válvula dosadora, é inserido no duto de escape para reagir com os gases provenientes da combustão do motor, visando a redução do NOx, transformando-o em nitrogênio comum e vapor d'água.

A tecnologia BlueTec5 também possibilita ao motor do produto a adequação não apenas ao diesel tradicional, de petróleo, mas também ao diesel de cana e ao biodiesel (MB, 2011). O diesel de cana foi testado pela área de Desenvolvimento em 2009, sendo a companhia a primeira do setor a testar esse tipo de combustível no país.

Figura 15 - Comparativo de emissão de gases de efeito estufa do Diesel de Cana (AMD) e do Diesel fóssil (ANP32/07).

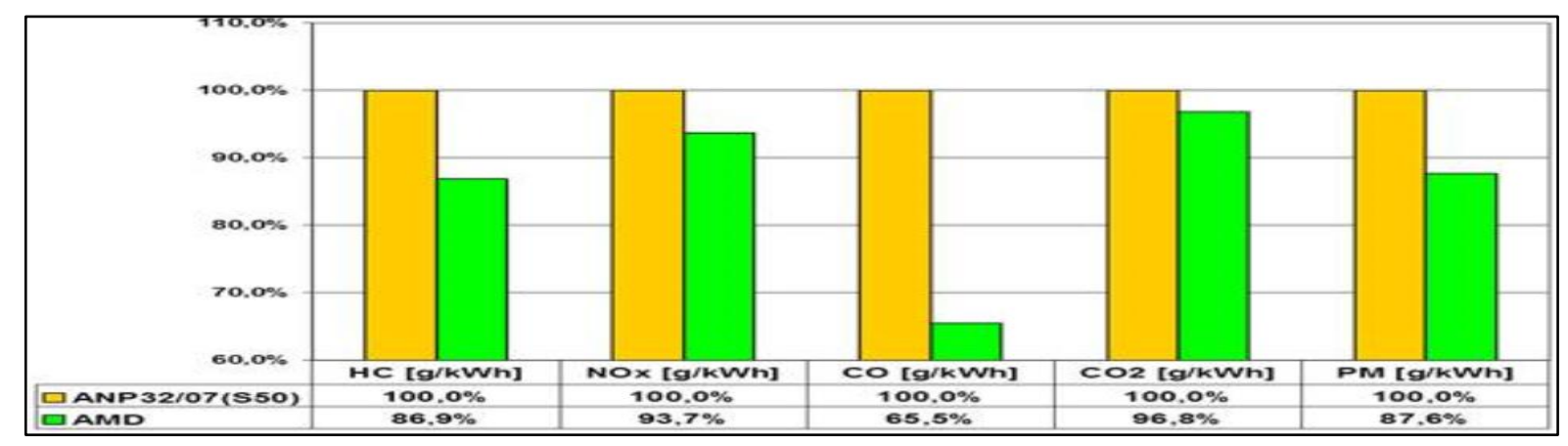

Fonte: MB, 2017d. 
O diesel de cana, que é um combustível em uso em outros países mas ainda não comercializado em larga escala no Brasil, é um hidrocarboneto fabricado a partir do caldo de cana-de-açúcar e, por ser de origem renovável, estima-se que a redução dos gases de efeito estufa seja superior a 90\%, quando comparado ao uso do diesel fóssil (MB, 2017d). O desempenho do motor utilizando esse tipo de diesel se manteve, quando comparado ao diesel tradicional, aumentando a motivação para o uso dessa nova tecnologia de combustível. Sobre o biodiesel, a empresa chegou a realizar testes com diferentes percentuais de biodiesel no diesel comum, de 20\% (B20) até 100\% (B100), simulando condições severas de transporte em média e longa distâncias. O uso da mistura B20, por exemplo, contribuiu para uma redução de emissão de, aproximadamente, $22 \%$ de material particulado, que é o principal poluente de veículos comerciais em centros urbanos (MB, 2011).

Além da tecnologia BlueTec5, a área de Desenvolvimento progrediu na tecnologia BlueTec EEV que, com o uso do diesel de cana, atende aos padrões da norma europeia EEV Enhanced Environmentally Friendly Vehicle. O resultado do uso é uma redução de aproximadamente $90 \%$ nas emissões de gases de efeito estufa e de 30\% nas emissões de material particulado, quando comparadas aos limites estabelecidos pela legislação PROCONVE P-7 (MB, 2011).

Em relação à matéria-prima do caminhão, o material predominante é o aço, presente na cabine, no motor e no eixo. No caso do câmbio, que é um agregado de grande porte, o material predominante é o alumínio. Em ambos os casos, tanto o aço quanto o alumínio são materiais recicláveis e, em grande percentual, reciclados. Além dos metais, no desenho do produto é mencionada a possibilidade e a quantidade permissível de uso de material reciclado, sendo tal informação direcionada principalmente a peças plásticas, tapetes de borracha e compensados para apoio de cama. Com isso, o caminhão atinge um nível de reciclabilidade de aproximadamente $90 \%$.

Pelo fato de o desenho do caminhão ser proveniente da Alemanha, e adaptado ao mercado nacional pela empresa no Brasil, detalhes de reciclabilidade e desmontabilidade de peças e componentes não fazem parte da rotina de compartilhamento de informações. O que é compartilhado são especificações técnicas necessárias para a produção e requisitos legais ambientais, como a não utilização de algumas substâncias químicas em peças e componentes. No entanto, ao instalar novos processos produtivos ou novos produtos, são desenvolvidos cadernos técnicos com requisitos para fornecedores de peças e componentes, solicitando que seja considerada a reciclabilidade dos materiais e a desmontabilidade dos componentes 
fornecidos. Com isso, é viabilizada a remanufatura do produto e a destinação para a reciclagem de peças em final de vida.

Outra informação estabelecida pela área de Desenvolvimento, e que influencia os processos de outras unidades de análise, são os níveis de reparação e de desgaste permissíveis, que são estabelecidos para indicar o limite de uso do produto sem a necessidade de uma intervenção; se não for respeitado, pode gerar uma quebra e uma parada não programada do caminhão. Entretanto, a vida útil de um caminhão é relacionada à sua utilização. $\mathrm{O}$ desgaste de peças e componentes está diretamente relacionado com o emprego do veículo, incluindo rotas, tipos de carga, região de operação, entre outros fatores. Um caminhão de uso urbano, por exemplo, tende a ter como itens mais sujeitos ao desgaste aqueles ligados ao acionamento constante do motorista. Um caminhão rodoviário, em que o condutor normalmente não utiliza sistemas de acionamento com frequência, não terá esses itens com desgastes acentuados. Os itens em que desgastes ocorrem mais comumente em um caminhão são: embreagem, filtros, lonas ou pastilhas de freio, óleos e lubrificantes.

Por meio dos requisitos de cadernos técnicos, que consideram a desmontabilidade e a reciclabilidade, e os níveis de reparação e de desgaste permissíveis, a área de Desenvolvimento colabora para o funcionamento das unidades de análise: Programa ServicePlus, Programa Service 24h; SelecTrucks e Remanufatura.

A desmontabilidade facilita o processo, tanto de remanufatura quanto de manutenção, já que, quanto mais desmontável for a peça, menor o número de componentes a serem trocados em pequenas manutenções, e mais fácil o processo de desmonte de componentes durante a remanufatura. A desmontagem é um fator de relevância, principalmente em agregados que são remanufaturados, como câmbios e motores. Nesses componentes, todas as peças podem ser removidas, possibilitando a remanufatura dos blocos e das peças separadamente. A reciclabilidade é um fator importante para peças em final de vida, possibilitando o envio dos materiais residuais para reciclagem, fazendo com que retornem ao mercado como matériaprima de novos produtos e processos. Os níveis de reparação e desgaste permissíveis estabelecem a periodicidade da manutenção preventiva do Programa ServicePlus, que pode ser também estabelecida conforme o objetivo de uso do caminhão, que, dependendo de sua função, pode desgastar mais ou menos as peças e os componentes. Tanto em manutenções corretivas quanto em manutenções rotineiras na SelecTrucks, a reciclabilidade influencia a redução de descarte para aterro e o coprocessamento de resíduos provenientes de veículos que passaram por manutenção, uma vez que as peças obsoletas retiradas dos caminhões podem, se não forem remanufaturadas, ser recicladas no mercado. Componentes provenientes de veículos de testes, 
quando em condições, são enviados para a Remanufatura, em vez de serem sucateados para reciclagem.

\subsection{UNIDADE DE ANÁLISE LOJA VIRTUAL DE PEÇAS}

Utilizando uma plataforma e-commerce, a companhia desenvolveu uma Loja Virtual de Peças onde o cliente, sem precisar se deslocar fisicamente, pode acessar diversos serviços, como informações de peças disponíveis em concessionárias próximas, detalhamento de preços, ofertas, aplicações e condições de pagamento. As compras podem ser feitas online ou em concessionárias, dependendo do tipo e da disponibilidade do produto. Podem ser adquiridas tanto peças novas como peças remanufaturadas (MB, 2017a).

Enquanto a companhia é responsável pelas regras e pelo layout da plataforma, os concessionários ficam encarregados de administrar as ofertas disponíveis, numa espécie de vitrine de peças. As peças novas podem ser adquiridas online ou no concessionário, sendo a loja virtual um canal para verificar a disponibilidade da peça na região. As peças remanufaturadas, por sua vez, não podem ser adquiridas online, uma vez que o concessionário precisa avaliar visualmente, validar e receber a usada em troca.

$\mathrm{O}$ acesso às lojas virtuais é regional. Ao acessar o website da fabricante, no tópico da Loja Virtual de Peças, há um campo onde o cliente deve mencionar a região onde ele está localizando para, ao clicar no link da loja, ser direcionado à respectiva concessionária de sua região. Dessa forma, o cliente de uma região não acessa concessionárias de outras regiões, evitando competição. Caso o concessionário não possua a peça requisitada, é feito o contato com a fábrica para o envio da peça, alterando-se apenas o tempo de entrega ao cliente.

A Loja Virtual de Peças é uma iniciativa que busca facilitar a aquisição de peças e componentes por meio de um canal em crescimento, que é o e-commerce, e constitui uma ferramenta complementar ao meio tradicional, e não substitutivo, pelo menos até o momento. Assim, não há uma estimativa de redução de lojas físicas ou de uso de espaço em razão da virtualização. No entanto, graças à Loja Virtual de Peças, concessionários não precisam estocar peças com baixo giro de venda, o que economiza espaço e estoque.

Adicionalmente, a Loja Virtual aumenta a divulgação das peças remanufaturadas, o que incentiva o cliente a não descartar peças usadas, mas sim utilizá-las como parte do pagamento na aquisição das remanufaturadas, que possuem qualidade e garantia de peças novas. Como resultado, as peças usadas não são descartadas no meio ambiente ou mesmo destinadas ao mercado paralelo, o que poderia gerar tratamentos das peças que não considerem os impactos 
ambientais, diferentemente do que ocorre no ambiente controlado da Remanufatura da companhia.

A Loja Virtual de Peças contribui com as unidades de análise Remanufatura, Programa ServicePlus e SelecTrucks. Graças à Loja, peças remanufaturadas são divulgadas virtualmente para clientes, possibilitando seu uso em manutenções que ocorrem na SelecTrucks ou em concessionários, por meio do Programa ServicePlus. O Programa Service24h é responsável por assistências em panes de campo, não sendo utilizada a Loja Virtual de Peças para a aquisição de peças e componentes, mas sim a avaliação do técnico responsável pelo reparo.

\subsection{UNIDADE DE ANÁLISE PROGRAMA SERVICEPLUS}

Para fornecer um serviço de manutenções e reparos periódicos de seus produtos, a companhia desenvolveu o Programa ServicePlus, em que a responsabilidade pelas manutenções e reparos periódicos é da empresa e de sua rede de concessionários, utilizando mão de obra especializada e condições controladas na execução das atividades. O programa possui diferentes categorias, envolvendo principalmente manutenções preventivas para troca de óleo, peças e fluidos (MB, 2017a).

Os planos de manutenção, quando aplicados pelo cliente segundo as premissas do programa, auxiliam o desempenho do produto, diminuindo o consumo de combustível e evitando paradas não programadas e falhas durante o percurso. O plano completo oferece, além da troca periódica de fluidos, óleos e reparos corretivos, a troca de itens de desgaste conforme a durabilidade das peças, e o socorro mecânico, via canal específico de comunicação (MB, 2017b).

Uma possibilidade do Programa ServicePlus é a realização da manutenção dentro do espaço do cliente, adequando-o às condições da fábrica e dos concessionários. Isso evita custos e tempo adicionais com deslocamento dos veículos (MB, 2017b), além de riscos para o meio ambiente, como vazamentos de fluidos no trajeto e até consumo de combustível e emissões atmosféricas, que são inerentes ao transporte.

Estão no contrato de cobertura completa do Programa tanto manutenções preventivas quanto corretivas. Nas revisões preventivas, estãoincluídos óleos e fluidos, peças e mão de obra. Nas revisões corretivas, peças, mão de obra, óleos e fluidos para reparos em geral. 
Quadro 20 - Escopo dos serviços do Programa ServicePlus.

\begin{tabular}{|c|c|c|}
\hline 这 & $\begin{array}{c}\text { Tipo de } \\
\text { Atendimento }\end{array}$ & Escopo \\
\hline \multirow{3}{*}{ 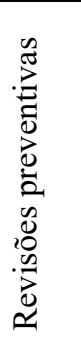 } & Óleos e Fluidos & $\begin{array}{l}\text { Motor, caixa de transmissão, eixo diferencial, retarder, fluido de freio, fluido de } \\
\text { embreagem, graxa (engraxamento dos chassis e peças móveis), graxa do cubo de } \\
\text { roda, líquido de arrefecimento e suspensão da cabina. }\end{array}$ \\
\hline & Peças & $\begin{array}{l}\text { Elemento do filtro de óleo do motor; aneis de escoamento ou enchimento do cárter, } \\
\text { caixa de transmissão e eixo diferencial; anel de vedação do cubo de roda; cartucho } \\
\text { secador de ar do freio; elemento do filtro de ar do motor; filtro do ar condicionado; } \\
\text { elemento do filtro principal de combustível; filtro do ADBLUE; elemento do filtro } \\
\text { separador de água; junta da tampa do cabeçote; e travas do cubo de roda. }\end{array}$ \\
\hline & Mão de Obra & Troca de óleo dos agregados e demais serviços de mão de obra da revisão. \\
\hline \multirow[t]{2}{*}{ 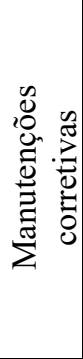 } & $\begin{array}{l}\text { Peças, mão de } \\
\text { obra, óleos e } \\
\text { fluidos para } \\
\text { reparos em geral }\end{array}$ & $\begin{array}{l}\text { Motor, caixa de transmissão, eixo diferencial, embreagem completa, alternador, } \\
\text { amortecedor da cabina, aneis vedadores, buchas e amortecedores, correias, coxins, } \\
\text { farois e lanternas com defeito proveniente de falha elétrica, feixe de molas } \\
\text { (mediante análise técnica), mecanismo do vidro (manual e elétrico), módulos } \\
\text { eletrônicos, motor de partida, palhetas do limpador de para-brisa, quinta-roda } \\
\text { (lubrificação, regulagem e ajustes), rolamentos e tubulação do escapamento. }\end{array}$ \\
\hline & $\begin{array}{l}\text { Outras Coberturas } \\
\text { (suporte Programa } \\
\text { Service24h) }\end{array}$ & Guincho e socorro mecânico no local da pane \\
\hline
\end{tabular}

Fonte: Autor

Além dos serviços de responsabilidade da companhia, são dadas instruções ao motorista no manual do produto, de forma a manter o bom desempenho do caminhão. Antes do funcionamento do motor, é recomendado verificar o nível de óleo do motor; drenar a água acumulada no pré-filtro de combustível; verificar o estado geral e a inflação dos pneus; verificar vazamentos em geral (água, óleo, fluidos e combustível); e verificar o funcionamento dos farois, lanternas, luzes indicadoras de direção, luz de freio e luz de marcha a ré. Após ligar o motor, é recomendado verificar a pressão pneumática do sistema de freios; verificar o funcionamento do tacógrafo; verificar o funcionamento do alarme sonoro e das luzes-piloto de advertência; e verificar o abastecimento de combustível e de ARLA32. Uma vez por semana, ao menos, é recomendado verificar o estado da correia de acionamento Poli-V; limpar para-brisa, vidros e espelhos retrovisores; comprovar o funcionamento de trincos e fechaduras das portas; verificar o nível de fluido do sistema de acionamento da embreagem; verificar o abastecimento do reservatório do lavador do para-brisa; limpar os farois e lanternas; comprovar o funcionamento do limpador do para-brisa e verificar as condições dos braços de acionamento e palhetas do limpador; verificar o aperto dos parafusos de fixação das rodas; calibrar os pneus, inclusive da roda sobressalente; para veículos com reguladores manuais de freio, regular o freio das rodas; e para os veículos utilizados predominantemente em condições fora-de-estrada, lubrificar as juntas universais das árvores de transmissão. 
Um dos focos do Programa ServicePlus é incentivar a prática de revisões periódicas e a realização das revisões e manutenções preventivas, de forma a aumentar o tempo de uso do produto e evitar as paradas não programadas, o que demonstra que o condutor também é responsável pelo bom funcionamento do caminhão. Em termos ambientais, o manual do caminhão explica o funcionamento da tecnologia BlueTec5, enfatizando a importância do abastecimento somente com óleo diesel de baixo teor de enxofre, e o uso do ARLA32. Outro fator de relevância ambiental é que, após ultrapassados os primeiros 90 dias de garantia, os serviços de manutenção podem utilizar peças remanufaturadas. Tal prazo se dá por estratégia da companhia, que prefere utilizar peças novas, em caso de necessidade de troca com menos de 3 meses da vigência da garantia. O Programa ServicePlus é o destino de produtos das unidades de análise Loja Virtual de Peças, Programa Service24h e Remanufatura.

O Programa ServicePlus pode utilizar peças adquiridas pela Loja Virtual de Peças. Em caso de panes de campo, é auxiliado pelo Programa Service24h. Peças remanufaturadas podem ser utilizadas em manutenções, desde que respeitado o período de 90 dias de garantia legal. Após esse período, mesmo vencendo a garantia contratual, o cliente pode utilizar peças remanufaturadas, à base de troca de peças usadas, ao realizar manutenções em concessionárias da marca. Com o vencimento da garantia, o serviço continua disponível, entretanto, custeado pelo cliente.

\subsection{UNIDADE DE ANÁLISE PROGRAMA SERVICE24H}

O Programa Service24h oferece um serviço assistencial em todo o território nacional, acessível 24 horas por dia, via canal telefônico de comunicação. Em seu escopo estão: socorro mecânico, serviços de guincho, táxi, hospedagem, transporte de retorno ao domicílio, remoção hospitalar, auxílio em caso de problemas com pneus, e auxílio em caso de falta de combustível (MB, 2017a).

O programa atende os produtos Caminhões, Vans e Micro-Ônibus que estão no período de cobertura da garantia e tenham tido alguma parada não prevista, causada por pane mecânica, elétrica ou eletrônica. $\mathrm{O}$ atendimento no local da falha é priorizado, desde que as condições ambientes e de complexidade da falha o possibilitem. Caso não seja possível, o serviço de reboque é acionado, direcionando o veículo para um concessionário.

Ao receber o contato do cliente informando a ocorrência da pane no veículo, a Central de Relacionamento com o Cliente - CRC faz o levantamento inicial dos dados do cliente, verificando a aplicação da cobertura do Programa Service24h, além de obter informações 
iniciais da pane. Estando o veículo coberto pelo Programa, a concessionária é contatada pela $\mathrm{CRC}$, e presta informações sobre a ocorrência, para que o técnico do concessionário consiga identificar quais peças e ferramentas devem ser utilizadas na manutenção in loco. Caso o concessionário não possa atender em tempo hábil, a CRC contata outro concessionário.

Se, pelo contato telefônico entre a CRC e o concessionário, for constatada a impossibilidade de reparação do veículo no local da ocorrência, o reboque será acionado. Caso o técnico não consiga efetuar o reparo no local, o reboque também será acionado.

Os indicadores de performance do Programa Service24h são:

a) Índice de reparo na estrada: percentual de reparo e liberação in loco dos veículos atendidos na estrada ou na via;

b) Índice de recusa: percentual de recusa do concessionário em atender a casos direcionados pela CRC;

c) Índice de aceitação: percentual de aceite do concessionário em atender os casos direcionados pela CRC;

d) Índice de deslocamento: tempo de chegada do plantonista ao local, a partir do aceite;

e) Índice de reparo no local: tempo necessário para reparar e liberar o veículo, após a chegada do técnico ao local;

f) Índice de solução: tempo total para a resolução do caso, do primeiro contato do cliente com a CRC até a liberação efetiva do veículo;

g) Índice de reparo no concessionário: tempo de reparo para os veículos que tenham sido removidos para o concessionário;

h) Índice de satisfação do cliente: percentual de clientes satisfeitos após a conclusão do atendimento.

Apesar de possuir em seu escopo a manutenção corretiva dos produtos, o Programa Service $24 \mathrm{~h}$ traz benefícios, como a execução dos serviços de forma controlada, com pessoal treinado, para que resíduos não sejam descartados inadequadamente durante as atividades de assistência técnica. Quando rebocados para concessionários, as manutenções dos veículos ocorrem em local com controle operacional, e também evitam descartes inadequados de resíduos dos processos, como fluidos veiculares ou estopas e panos com óleo. Com o vencimento da garantia, o serviço continua disponível, assim como o ServicePlus, entretanto, custeado pelo cliente. 


\subsection{UNIDADE DE ANÁLISE SELECTRUCKS}

Visando ampliar as possibilidades de aquisição de caminhões por seus clientes, a empresa criou a SelecTrucks, que é o seu próprio modelo de negócio para caminhões seminovos, implantado pela primeira vez no Brasil, no Grande ABC Paulista. Seu processo é responsável pela compra, estoque, manutenção e venda de caminhões seminovos de diversas marcas, apoiando os concessionários na negociação com os clientes (MB, 2013; SELECTRUCKS, 2017). Em 2017, a companhia possuía duas lojas no país, sendo uma no Grande ABC Paulista e outra em Betim, no estado de Minas Gerais.

Para avaliar a procedência dos caminhões, são realizadas vistorias, inspeções, regulações, homologações e verificações de histórico e procedência veicular. Com isso, um especialista responsável pela avaliação do caminhão emite um laudo com os reparos sugeridos (MB, 2013). Os reparos variam não apenas de acordo com o laudo, mas também com a marca do produto. Se a marca do caminhão seminovo for da própria companhia, podem ser utilizados componentes remanufaturados como troca pelos usados. Sendo assim, a SelecTrucks é um destino de peças remanufaturadas, reduzindo custos de manutenção e impactos ambientais provenientes da aquisição de novas matérias-primas, ou da geração de resíduos provenientes de peças não remanufaturadas.

Como as manutenções da SelecTrucks são realizadas conforme as avaliações dos técnicos, e a aquisição de peças e componentes não é feita pelos clientes, mas pela própria loja, não é utilizada a Loja Virtual de Peças como canal de compras, mas sim o contato direto com o fabricante ou com o distribuidor.

\subsection{UNIDADE DE ANÁLISE REMANUFATURA}

É considerada Remanufatura toda a operação de reindustrialização feita pelo fabricante original, do que está sendo remanufaturado. A diferença entre reparação, recondicionamento e remanufatura é: reparação, na maioria das vezes, é a substituição das peças danificadas; recondicionamento são operações que necessitam de processos de usinagem (retífica) realizados por terceiros; e remanufatura é um processo de reindustrialização completo, feito pelo fabricante original que, sendo detentor do projeto, possui processos, maquinário, mão de obra e ferramental especializados naquilo que está sendo remanufaturado.

Instalada no Brasil há mais de 10 anos, a Remanufatura da companhia oferece uma gama de produtos remanufaturados, que abrange motores, câmbios, embreagens, motores de partida, 
unidades injetoras, alternadores, turbinas, diferenciais, bombas de óleo, bombas d'água, cabeçotes, pinças de freio, kits de embreagem, válvulas 4 circuitos e secadores de ar. Os principais são os motores e os câmbios, que são agregados de grande porte e possuem diversas peças em sua composição.

Um dos incentivos ao cliente para o uso de produtos remanufaturados é o custo reduzido e a garantia de 12 meses, sem limite de quilometragem, sendo igual ao de uma peça nova, genuína. Outro atrativo é a possibilidade de o cliente utilizar uma peça usada como parte do pagamento de uma peça remanufaturada (MB, 2017a), e seu custo chega a 55\% do valor de uma peça nova $(\mathrm{MB}, 2011)$. Pelo fato de haver a redução de custo de manutenção e as peças remanufaturadas estarem disponíveis em concessionários, a quantidade de clientes que reparavam seus caminhões no mercado paralelo diminuiu, o que reduz o impacto ambiental na cadeia de manutenção, considerando que oficinas do mercado paralelo geralmente não possuem controle operacional ambiental, como bacias de contenção, gestão de insumos e destinação adequada de resíduos.

Para a companhia, o uso de produtos remanufaturados é menos oneroso do que a utilização de peças novas. Estima-se que $45 \%$ do custo de produção do caminhão seja proveniente de materiais, fazendo com que a Remanufatura seja considerada uma estratégia de alto retorno financeiro para a empresa em termos de cadeia do negócio. Adicionalmente, a tributação governamental para a venda de remanufaturados é diferenciada, e um meio para comprovar que o produto vendido é remanufaturado e não novo é por meio da entrada da peça usada, incentivando assim um sistema à base de troca. Por isso, para que o cliente possa ter desconto na aquisição de remanufaturados, é um requisito a entrega do usado, promovendo assim a logística reversa das peças e componentes usados. O perfil de sistema à base de troca reduz a espera do cliente para o reparo do produto, já que é necessário aguardar apenas a troca do componente usado por um remanufaturado na oficina, diferentemente de sistemas em que é necessário o cliente aguardar todo o processo de retirada do componente do caminhão, aplicação da remanufatura, montagem e disponibilização do caminhão. A operacionalização da logística de remanufaturados ocorre na venda das peças e componentes remanufaturados para as concessionárias, que os adquirem pelo menor valor possível, estocando-os em seu espaço. $\mathrm{O}$ transporte é feito, geralmente, por meio rodoviário. Para manter o menor preço possível do remanufaturado, é firmado um acordo em que a concessionária se compromete a retornar para a companhia a peça usada e em condições de ser remanufaturada. Caso isso não ocorra no prazo estipulado no acordo, é emitida uma nota de cobrança adicional ao concessionário. Tal trâmite 
incentiva o concessionário, ao comercializar os remanufaturados, a adquirir as peças usadas e retorná-las para a companhia, sendo elas a entrada no processo de Remanufatura.

As peças e componentes a serem remanufaturados podem ser provenientes de produtos testados pela área de Desenvolvimento, refugos provenientes da produção de novos caminhões e das atividades de pós-vendas, como o Programa ServicePlus e o contato com concessionários. Podem ser remanufaturadas peças e componentes com quebras, desgastes ou necessidade de atualização técnica. Não são remanufaturadas peças em que a complexidade da quebra ou do desgaste não compensa em termos de custo-benefício. Peças que estão em boas condições também não são remanufaturadas, sendo montadas, testadas e retornadas ao produto. $\mathrm{O}$ processo de Remanufatura possui como etapas: o recebimento do componente usado, a avaliação, a desmontagem, a limpeza, o processamento (que pode utilizar usinagem, dependendo da necessidade da peça), aprovação, montagem e avaliação de resultado. Tal sequência ocorre tanto para motores quanto para câmbios. No entanto, pelo fato de o motor ser de ferro fundido e o câmbio ser de alumínio, o processo de limpeza é diferente. No caso do motor, há uma etapa de aquecimento em um forno, para que sujeiras fiquem secas, e um jateamento com granalhas de aço, com o uso de ar comprimido para retirar as granalhas remanescentes no motor. O câmbio, por sua vez, por ser de alumínio, não é aquecido no forno e a granalha utilizada no jateamento é de plástico.

Quanto mais específica e maior o valor da peça, mais viável economicamente é o reparo. Caso a remanufatura não seja suficiente, a peça é encaminhada para a restauração, que é um processamento mais complexo, envolvendo ações como deposição de metais e conformação térmica. 
Figura 16 - Fluxo do processo da Remanufatura da companhia.

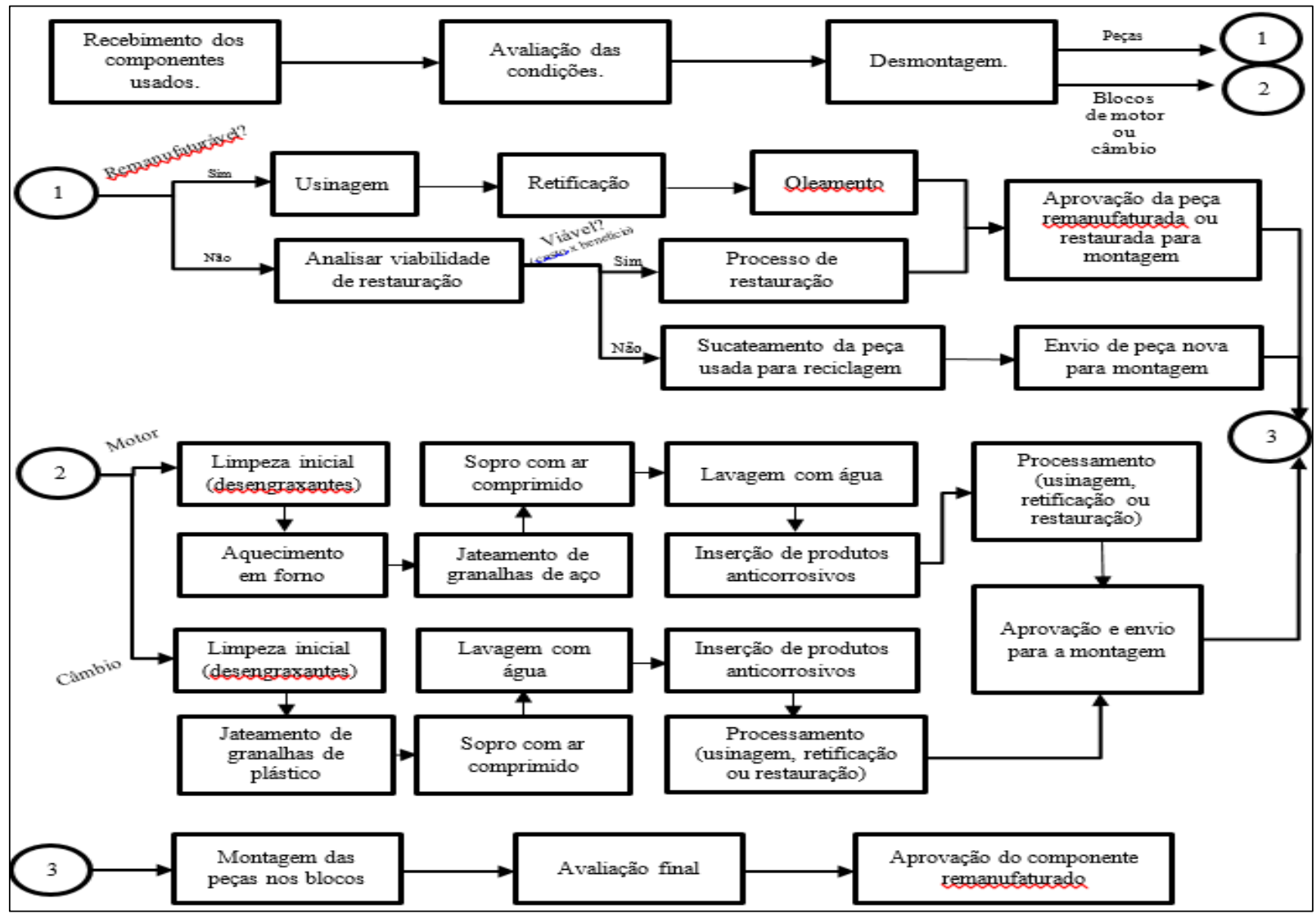

Fonte: Autor

O processo da Remanufatura utiliza peças originais ou já remanufaturadas, em espaço com controles operacionais dos aspectos ambientais inerentes à atividade (MB, 2017a), sendo que os principais são: consumo de energia elétrica; consumo de insumos, como água, líquido desengraxante, estopa, panos e óleo lubrificante; consumo de peças e componentes novos, quando não houver remanufaturados para o componente; geração de resíduos de materiais contaminados com óleo; geração de efluentes industriais, que passam por uma estação de tratamento; e geração de sucata metálica proveniente de peças não remanufaturáveis. Todos os resíduos gerados são enviados para reciclagem e administrados por parceiros externos, que são avaliados e aprovados pela empresa, sendo considerados na avaliação tanto quesitos técnicos quanto de cumprimento de conformidade legal ambiental e certificação ISO 14001. Quando não contaminados, os resíduos recicláveis são enviados para parceiros que podem aplicar o processo de upcycling no material e, nesse caso, a empresa recebe um valor com a venda desses materiais. No caso dos resíduos com contaminantes, como óleo, é aplicado um processo de downcycling que gera custos para a companhia. Esses materiais são incrementados em 
compostos, a serem utilizados como combustível em outros processos, por meio do coprocessamento.

Quadro 21 - Principais aspectos ambientais da Remanufatura e seus respectivos controles operacionais.

\begin{tabular}{|l|l|}
\hline Principais aspectos ambientais da Remanufatura & Controles operacionais \\
\hline Consumo energético (energia elétrica) & Monitoramento e metas para redução do consumo. \\
\hline $\begin{array}{l}\text { Consumo de insumos (ex: água, desengraxante, } \\
\text { estopa, panos e óleo lubrificante) }\end{array}$ & $\begin{array}{l}\text { Monitoramento do consumo e conscientização para } \\
\text { os colaboradores, visando o consumo consciente. }\end{array}$ \\
\hline Consumo de peças e componentes novos & $\begin{array}{l}\text { Sem controles. Ocorre conforme a necessidade do } \\
\text { componente remanufaturado. }\end{array}$ \\
\hline $\begin{array}{l}\text { Geração de resíduos de materiais contaminados com } \\
\text { óleo }\end{array}$ & $\begin{array}{l}\text { Monitoramento e metas para redução da geração, } \\
\text { bacias de contenção em locais com risco de } \\
\text { vazamento de fluidos, destinação para } \\
\text { coprocessamento. }\end{array}$ \\
\hline Geração de efluentes industriais & Tratamento na estação de tratamento de efluentes. \\
\hline Geração de sucata metálica & Envio para reciclagem. \\
\hline
\end{tabular}

Fonte: Autor

Em termos ambientais, no produto há um reaproveitamento de cerca de $70 \%$ do metal utilizado originalmente na sua fabricação, reduzindo tanto o descarte de materiais quanto o consumo de nova matéria-prima. Os demais componentes não remanufaturados são destinados para reciclagem. Entre 2004 e 2011, foram remanufaturados aproximadamente 28.800 motores e 13.700 câmbios (MB, 2011).

\subsubsection{Remanufatura de Motores}

O processo de remanufatura de motores começa com uma avaliação visual da peça usada, na qual o cliente recebe a informação de custos para a aplicação da remanufatura. Em seguida, ocorre a limpeza, realizada com equipamentos especiais para alcançar locais de difícil acesso do motor. A Figura 16 apresenta os locais do motor que recebem intervenções da remanufatura: (1) bloco, virabrequim, eixo de comando de válvulas e demais peças, após aprovação visual, são submetidas a testes para identificar possíveis falhas e imperfeições, havendo substituições por novas, se necessário; (2) apertos, regulagens, torques e embuchamentos, executados com equipamentos e ferramentas especiais, por profissionais da linha de montagem, para assegurar precisão no ajuste de cada peça; (3) brunimento controlado dos cilindros, de acordo com especificações do projeto de fábrica, o que garante a formação de película homogênea de lubrificação e maior vida útil ao motor remanufaturado; (4) bomba de óleo, submetida a testes minuciosos para garantir a pressão ideal do óleo de lubrificação em 
todas as galerias internas e prolongar a vida útil do motor; e (5) virabrequim, $100 \%$ testado e balanceado (MB, 2017a).

Figura 17 - Locais do motor que recebem intervenção da Remanufatura.

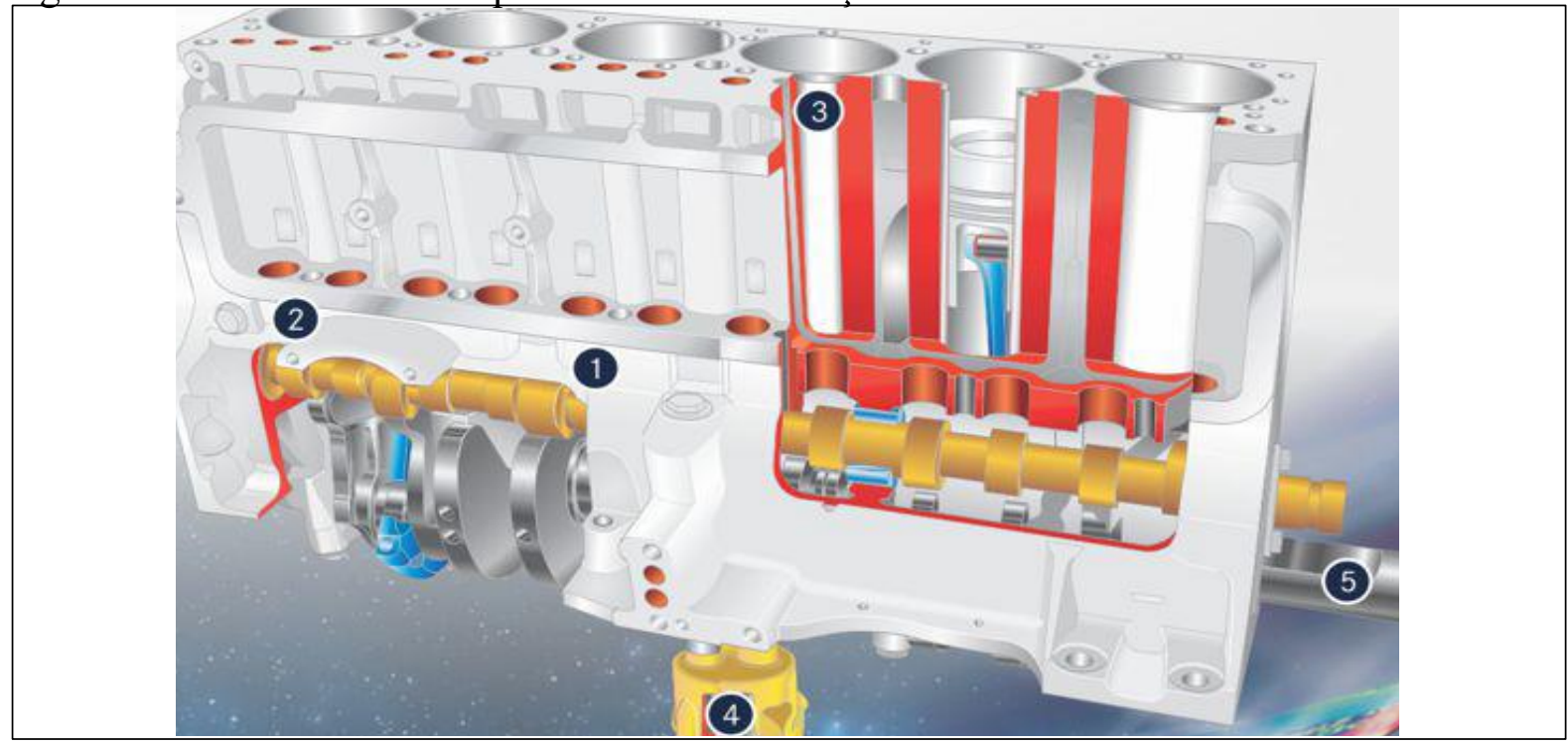

Fonte: MB, 2017a.

A fase de acabamento envolve a inserção de produto protetivo e pintura, utilizando práticas como se a peça fosse nova, e finalizando com a aplicação de óleo específico e utilização de embalagem especial anticorrosão (MB, 2017a).

\subsubsection{Remanufatura de Câmbios}

No caso do câmbio, após inspeção visual ocorre a limpeza, utilizando os mesmos métodos da remanufatura de motor. A Figura 17 apresenta os locais do câmbio que recebem intervenções da remanufatura: (1) carcaças, eixo piloto, eixo principal, engrenagens e demais peças, após aprovadas visualmente, são submetidas a testes para identificação de triscas e imperfeições, havendo substituição por peças novas, se necessário; (2) principais itens substituídos por peças novas, que são os aneis sincronizadores, rolamentos, retentores, gaxetas, aneis o'rings e molas de aneis de sincronização (MB, 2017a). 
Figura 18 - Locais do câmbio que recebem intervenção da Remanufatura.

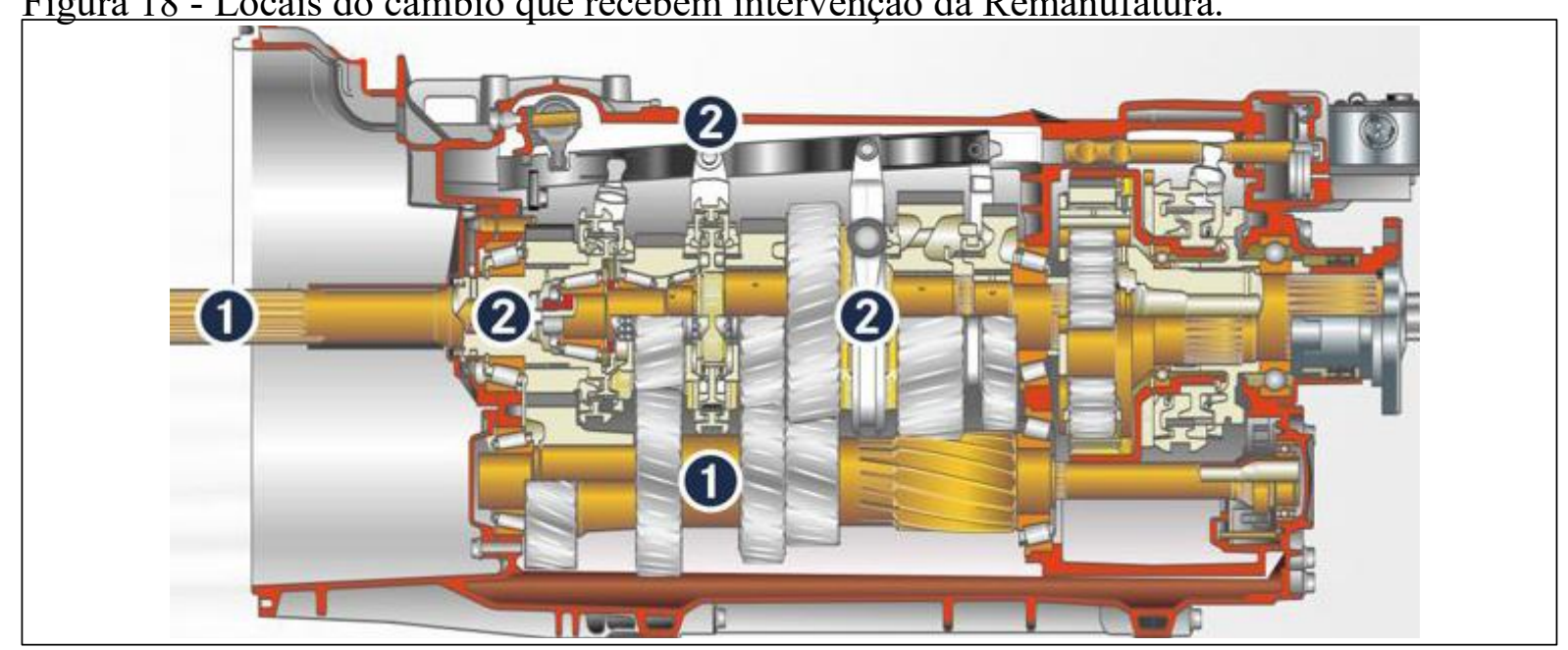

Fonte: MB, 2017a.

Assim como o motor, o câmbio remanufaturado recebe em seu acabamento a proteção e a pintura, sendo posteriormente testado no banco de provas e atualizado tecnicamente, se for preciso (MB, 2017a).

A Remanufatura contribui com as unidades de análise Loja Virtual de Peças, Programa Service24h, Programa ServicePlus e SelecTrucks. Com a desmontabilidade e a reciclabilidade consideradas no desenvolvimento do caminhão, a Remanufatura desmonta todas as peças presentes nos componentes Câmbios e Motores e as remanufatura, restaura ou recicla, conforme as condições presentes. $\mathrm{O}$ estabelecimento dos níveis de reparação e de desgaste são indicadores para os usuários do caminhão efetuarem as manutenções, trocando componentes sem condições de uso por componentes remanufaturados. Dentro da companhia, componentes de veículos de testes ou rejeitos do processo de produção são enviados para serem remanufaturados. As unidades de análise que são destino virtual ou físico das peças e componentes remanufaturados são: a Loja Virutal de Peças, que possui informações de disponibilidade; o Programa ServicePlus, que pode utilizar peças remanufaturadas em manutenções programadas; o Programa ServicePlus, que pode utilizar peças remanufaturadas em manutenções corretivas; e o SelecTrucks, que pode utilizar peças remanufaturadas em manutenções de caminhões seminovos da marca. 


\subsection{PEÇAS E COMPONENTES EM FINAL DE VIDA}

Quando as peças e os componentes atingem uma condição em que a remanufatura não é possível, geralmente por quebra ou desgaste, devem ser submetidos ao processo de desmontagem e destinação para reciclagem.

No Brasil, existem requisitos legais que regulam as atividades de desmontagem e destinação de veículos em final de vida, como a Lei Federal 12.977, de 2014, que regula e disciplina a atividade de desmontagem de veículos automotores terrestres. No estado de São Paulo, existem a Lei Estadual 15.276 e a Portaria Detran SP no 1.215, de 2014, que dispõem sobre a destinação de veículos terrestres em fim de vida útil e dão outras providências. De forma mais didática, a AEA - Associação Brasileira de Engenharia Automotiva - divulgou em 2012 uma Cartilha de Destinação de Materiais Veiculares que estão em final de vida.

Grande parte dos materiais utilizados em um veículo é reciclável, sendo que: 75\% são metais, $13 \%$ polímeros, $5 \%$ elastômeros, $2 \%$ vidros, $2 \%$ fluidos e $3 \%$ outros materiais. Por isso, um veículo em final de vida é rico em matéria-prima que pode retornar à cadeia produtiva (AEA, 2012). No entanto, para que esses materiais retornem à cadeia de forma ambientalmente segura, existem os Centros de Reciclagem Veicular (CRVs), que são responsáveis pelo recebimento, tratamento, desmontagem e envio das peças para reciclagem, dos veículos em final de vida, e os Centros que, além de enviar as peças para reciclagem, reaproveitam as que possuem condições de retornar ao mercado.

Nos CRVs, os veículos recebidos pelos usuários são coletados, pré-tratados, desmontados e picotados. Os rejeitos do processo são enviados para reciclagem, para incineração ou para aterro, conforme suas características (AEA, 2012).

Figura 19 - Fluxo de desmontagem e reciclagem de um veículo em final de uso nos CRVs.

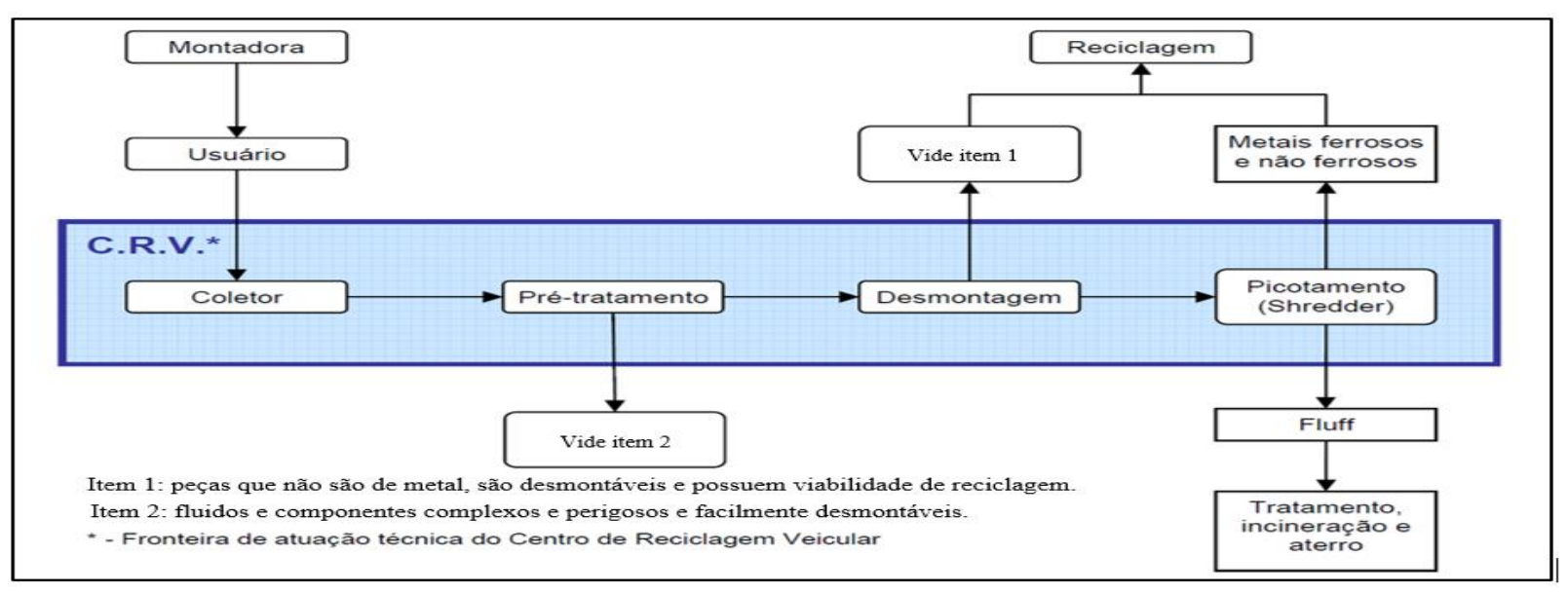

Fonte: AEA, 2012. 
Após a coleta do veículo em final de vida, é iniciado o pré-tratamento, que consiste na retirada de fluidos e componentes complexos que são de fácil desmonte. Os fluidos retirados nessa etapa são: combustível; fluido de freio; líquidos de arrefecimento e do limpador de parabrisa; gás refrigerante; e óleos do motor, da transmissão, do diferencial, da direção hidráulica e dos amortecedores. Os componentes retirados são: bateria; filtros de óleo e de combustível; tanques de gás liquefeito de petróleo ou de gás natural, quando o veículo os possuir; pneus; conversor catalítico; peso balanceador da roda; extintor de incêndio; e air bag, com um processo especial para neutralizar seu potencial de explosão (AEA, 2012).

A etapa de desmontagem é opcional, sendo aplicada quando o veículo possuir peças com facilidade de acesso e desmonte; com composição não complexa, o que viabiliza a reciclagem; e com potencial tecnológico e econômico que justifique a realização dessa etapa (AEA, 2012).

A última etapa que ocorre dentro do CRV é o Shredder, que é uma estação de picotamento para, em escala industrial, reduzir as dimensões do veículo em final de vida. Por meio desse processo, a fração metálica, ferrosa ou não ferrosa, pode ser separada e enviada para reciclagem, em usinas de siderurgia. A fração não metálica, chamada de fluff, é um composto formado principalmente por polímeros (AEA,2012), e seu destino depende de sua composição, que pode variar conforme o veículo e o que foi aproveitado nas etapas anteriores. O fluff pode ser encaminhado para: incineração, caso tenha algum resquício de material perigoso ou contaminante; aterro, quando não houver contaminantes; ou ainda para reciclagem como combustível em usinas termoelétricas, se possuir um poder calorífico alto.

Além dos CRVs, que têm como foco a desmontagem e a reciclagem veicular, existem centros especializados na desmontagem e no reaproveitamento de peças. Um exemplo é a Renova Ecopeças, do grupo Porto Seguro, inaugurada em 2013, e que trabalha no reaproveitamento de peças originais usadas e na destinação ambientalmente correta de veículos em fim de vida útil das seguradoras Porto Seguro, Azul e Itaú, com baixa definitiva no Detran (RENOVA ECOPEÇAS, 2015).

O centro de desmontagem e reaproveitamento de peças possui dois processos principais, que são: a descontaminação dos veículos, que retira sobras de óleo, combustível e outros resíduos potencialmente impactantes ao meio ambiente; e a desmontagem, com a retirada de peças de lataria, componentes mecânicos, bancos e tapeçaria, vidros, componentes eletrônicos, rodas, pneus, itens de segurança e recorte do monobloco. No processo de descontaminação, o material retirado é coletado por empresas especializadas no processamento e na transformação 
desses materiais. No processo de desmontagem, as peças passam por um processo de separação e classificação quanto à qualidade e condições de reaproveitamento, sendo cada peça identificada e etiquetada para garantir sua procedência, rastreabilidade e histórico. As peças provenientes da desmontagem seguem para estoque e venda, sendo seu valor $50 \%$ a $60 \%$ menor do que uma nova original, dependendo de seu estado de conservação. As vendas ocorrem por meio de um canal e-commerce ou diretamente no balcão da Renova Ecopeças. Há também um canal criado pela empresa visando contato, não com usuários, mas diretamente com montadoras, oficinas reparadoras ou retíficas, para estabelecer gestão de logística reversa ou descarte controlado dos veículos e suas peças (RENOVA ECOPEÇAS, 2015).

Em relação à empresa objeto do estudo de caso, não há um controle sobre os centros de reciclagem veicular ou de reaproveitamento de peças. Nos manuais dos caminhões da companhia, são considerados em seu escopo toda a fase de uso do produto, inclusive questões ambientais em termos de trocas de fluidos e manutenções periódicas. Entretanto, ainda não é detalhado como o cliente pode proceder com seu veículo em final de vida. 


\section{ANÁLISE E DISCUSSÃO DOS RESULTADOS}

Este capítulo analisa e discute os resultados da pesquisa, segundo as categorias de análise do Referencial Teórico. Na Economia Circular, o princípio 1 trata de entradas, como insumos e matérias-primas, o princípio 2 apresenta os loops, que são as hierarquias de tratamento de materiais, e o princípio 3 refere-se à saída, por meio das externalidades (EMF, 2015). Em razão das características de circularidade de materiais e geração de resíduos, e das evidências encontradas nas unidades de análise, grande parte do conteúdo dos resultados é relacionado ao princípio 2. São utilizados na Análise e Discussão dos Resultados tanto os elementos da Economia Circular levantados no Referencial Teórico, quanto esses elementos adequados ao estudo, conforme apresentado no Quadro 13. Para estudar as unidades de análise e sua localização na cadeia da companhia, foi elaborada a Figura 31, que traz os fluxos de materiais físicos, que podem ser peças ou caminhões inteiros, destacando-se em azul as unidades de análise pesquisadas e mantendo em branco outras envolvidos nessa cadeia, que são a manufatura, a concessionária, o usuário, os centros de reciclagem e reaproveitamento de peças e componentes de veículos em final de vida, e o fornecedor de matéria-prima.

Figura 20 - As unidades de análise na cadeia da companhia.

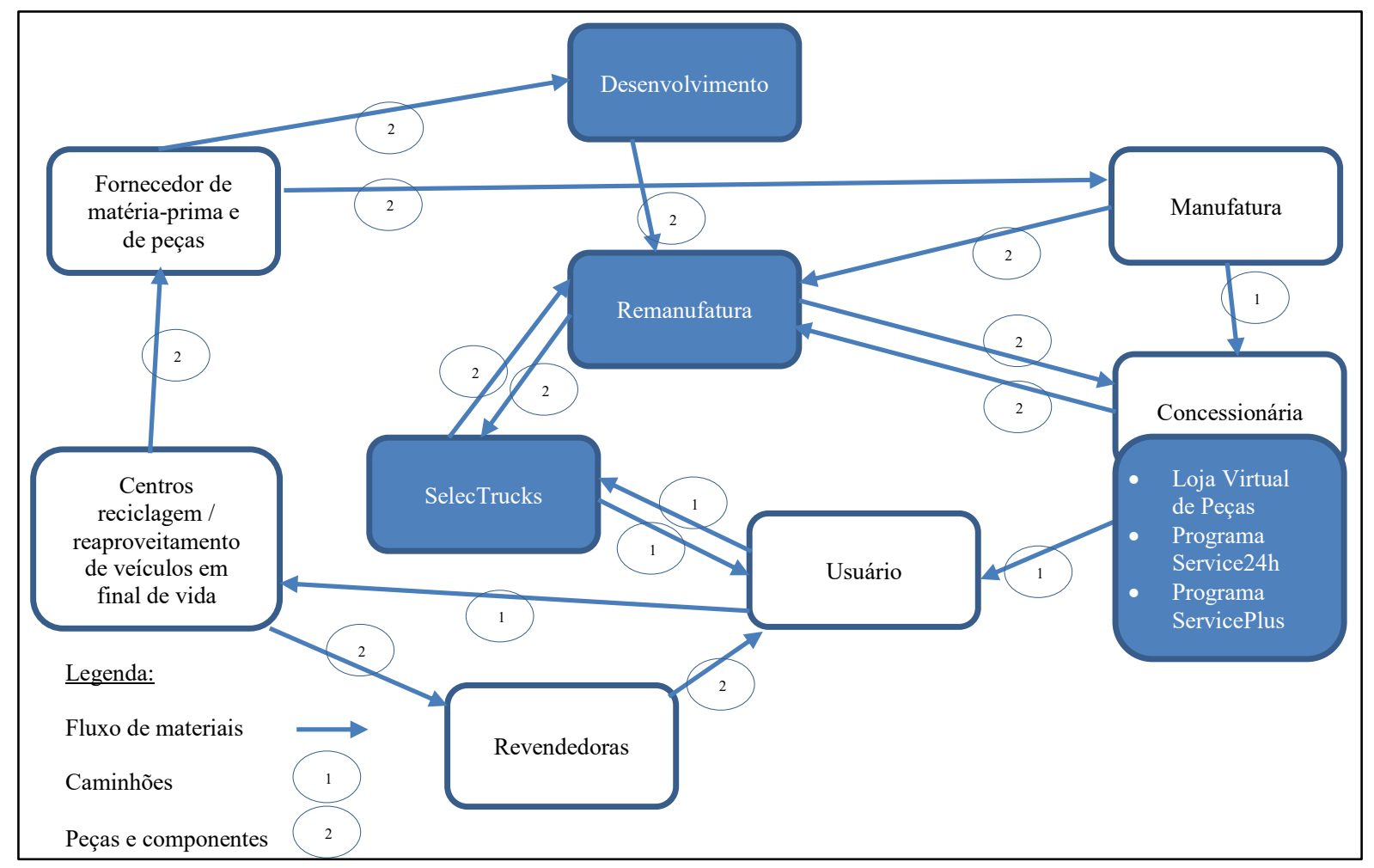

Fonte: Autor 
A unidade de análise Desenvolvimento estabelece o projeto do caminhão, o que é considerado para sua produção. Os veículos saem da Manufatura e são vendidos por meio das Concessionárias. Os usuários possuem como canal de comunicação as concessionárias ou as unidades de análise da estrutura de pós-vendas da companhia, como a Loja Virtual de Peças, o Programa Service24h e o Programa ServicePlus. Quando o usuário quer se desfazer do caminhão, uma opção é a venda para a $\underline{\text { SelecTrucks, }}$, podendo adquirir outro produto que satisfaça suas necessidades. A SelecTrucks pode utilizar peças remanufaturadas em suas manutenções, desde que o caminhão seja da marca da empresa. Os veículos em final de vida devem ser destinados pelo cliente a centros de reciclagem ou reaproveitamento, que revendem peças usadas em condições de serem reaproveitadas para revendedoras ou para usuários, ou as enviam para reciclagem, retornando a novos processos como matérias-primas.

A Economia Circular busca a otimização do uso de recursos naturais e a minimização dos descartes, desde a fase de projeto dos produtos (EMF, 2012), e, por meio do conceito "berço ao berço" (MCDONOUGH; BRAUNGAR, 2003), promove o uso de energias renováveis, a eliminação do uso de produtos químicos tóxicos, e a circularidade de materiais que antes estariam em final de vida (LEWANDOWSKI, 2016). Iniciativas como o uso de materiais alternativos, a desmaterialização, a virtualização e a circularidade de materiais auxiliam no equilíbrio dos fluxos de recursos renováveis e do capital natural (EMF, 2015; HINTERBERGER; SCHIMIDT-BLEEK, 1999; KORHONEN; WIHERSAARI; SAVOLAINEN, 2001; LIU et al., 2010; MELLINO et al., 2014; WACKERNAGEL; REES, 1997). Por meio das evidências encontradas, foi possível verificar onde cada unidade de análise está mais presente na estrutura da Economia Circular, e quais os elementos que estão sendo considerados nas atividades da companhia.

\subsection{AS UNIDADES DE ANÁLISE NA ESTRUTURA DA ECONOMIA CIRCULAR}

$\mathrm{Na}$ estrutura da Economia Circular, os materiais são presentes nos ciclos técnico e biológico (EMF, 2015). Como o estudo de caso trata de produtos técnicos em processos industriais, o escopo da análise e discussão de resultados prioriza o ciclo técnico da Economia Circular.

Durante a realização do estudo, foi possível evidenciar em que parte da estrutura da Economia Circular (EMF, 2015) cada unidade de análise está mais presente. A área de Desenvolvimento do Produto está relacionada ao Princípio 1 da Economia Circular, pelo fato de os projetos da companhia considerarem os materiais utilizados no caminhão, para 
proporcionar a reciclabilidade (AYRES, 1997), desmontabilidade (GU et al., 1997; WILLIAMS et al., 2008) e durabilidade (BOULDING, 1966; STAHEL; REDAY-MULVEY, 1981) do produto. A Loja Virtual de Peças também apresenta elementos do Princípio 1, por estar diretamente relacionada à virtualização (LEWANDOWSKI, 2016), que é uma forma de desmaterialização (AYRES, 1997; HINTERBERGER; SCHIMIDT-BLEED, 1999; KORHONEN; WIHERSAARI; SAVOLAINEN, 2001; MELLINO et al., 2014), ou seja, é uma alternativa que exerce a mesma função, com menor uso de materiais ou espaço físico.

Dentro do Princípio 2 da Economia Circular estão quatro unidades de análise. O Programa ServicePlus possui a área de manutenção (ABNT, 1994; BEVILACQUA; BRAGLIA, 2000; EMF, 2015), que é o primeiro elemento da hierarquia de tratamento de materiais (EMF, 2015), e estabelece que o produto circule no mesmo usuário pelo maior tempo possível. O Programa Service24h atua na manutenção corretiva dos caminhões, reparando-os no local da falha em caso de problemas simples, ou direcionando-os para locais com controle operacional, e assim evitar impactos ambientais decorrentes, por exemplo, de vazamento de óleo ou descarte de materiais contaminados em local inadequado. A SelecTrucks possui o elemento de reutilização (KIMURA et al., 2001; BRISSAUD; TICHKIEWITCH; ZWOLINSKI, 2006; AL-SALEM; LETTIERI; BAEYENS, 2009; AMELIA et al., 2009; OLIVEIRA; SILVA, 2011), que é o segundo na hierarquia do Princípio 2 (EMF, 2015), pois o produto, quando não é viável para determinado usuário, passa por uma manutenção e é vendido para outros usuários, sem passar por um processamento que gera resíduos. A remanufatura (LUND, 1983; JAYARAMAN; GUIDE JR; SRIVASTAVA, 1999; GUIDE, 2000; KEER; RYAN, 2001; SAVASKAN; BHATTACHARYA; VAN WASSENHOVE, 2004; BRISSAUD; TICHKIEWITCH; ZWOLINSKI, 2006; ATASU; SARVARY; VAN WASSENHOVE, 2008; AMELIA et al., 2009; ZHANG et al., 2011; AGRAWAL; ATASU; VAN ITTERSUM, 2015; ZHANG; CHEN, 2015; DIENER; TILLMAN, 2016) é o penúltimo elemento da hierarquia do Princípio 2 (EMF, 2015). Nele, o produto é reprocessado em condições controladas, retornando ao mercado com características de um produto novo. O último elemento da hierarquia é a reciclagem (NOCI, 1995; THORMARK, 2002; FRANCHETTI; MARCONATO, 2003; KANG; SCHOENUNG, 2005; AMELIA et al.; 2009; BRASIL, 2010; CAMPOS et al., 2009; ALI; KHAIRUDDIN; ABIDIN, 2013; EMF, 2015; CUCCHIELLA et al., 2016; LELLIS FERREIRA; FARIAS FILHO; QUELHAS, 2016; LESLIE et al., 2016; SHAHBAZI et al., 2016; SOO; COMPSTON; DOOLAN, 2016). Apesar de não haver uma unidade de análise da companhia indicada no elemento, o estudo considerou os Centros de Reciclagem Veicular para a coleta de dados. 
Em relação ao Princípio 3 (EMF, 2015), todas as unidades de análise atuam de forma a gerenciar e reduzir as externalidades negativas (PIGOU, 1932; COASE, 1960; BLACK, 1997; DEAN; MCMULLEN, 2007; EMF, 2015), provenientes do caminhão em seu ciclo de uso.

Figura 21 - As unidades de análise na estrutura da Economia Circular.

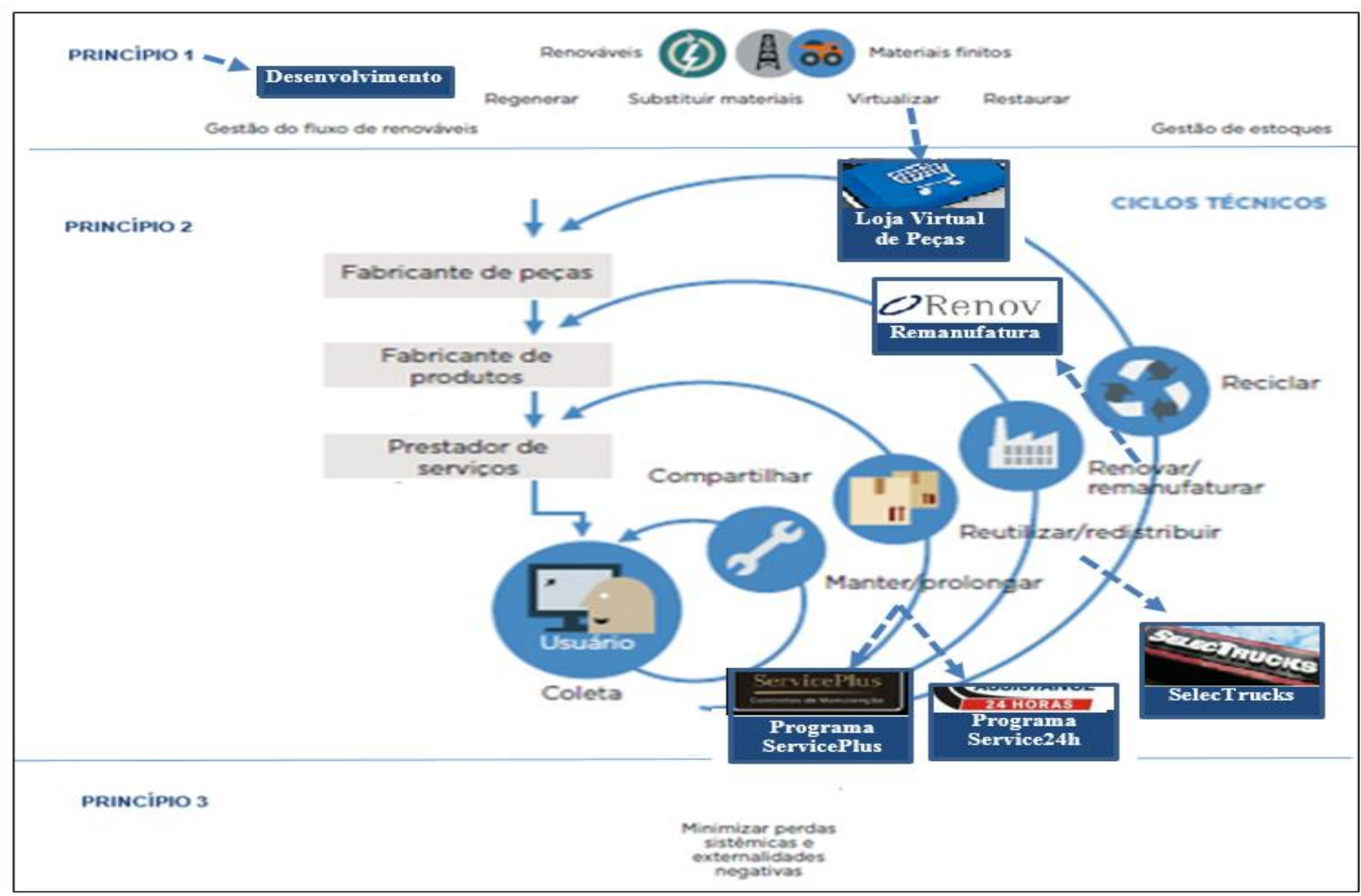

Fonte: Autor, adaptado de EMF, 2015.

Independentemente de onde se localizam na estrutura da Economia Circular, cada unidade de análise apresentou diferentes elementos por meio das fontes de evidência estabelecidas na Metodologia.

\subsection{OS ELEMENTOS DA ECONOMIA CIRCULAR NAS UNIDADES DE ANÁLISE}

Os elementos da subcategoria de gestão do fluxo de renováveis e de estoques foram identificados nas unidades de análise Remanufatura e Desenvolvimento, e também nas concessionárias e manufatura. Os elementos do ciclo técnico foram evidenciados em todas as unidades de análise e setores participantes. Já as evidências de elementos das externalidades foram encontradas na Remanufatura, no Desenvolvimento e nas concessionárias. 
Quadro 22 - Evidências encontradas e suas fontes.

\begin{tabular}{|c|c|c|c|c|}
\hline Subcategorias & $\begin{array}{l}\text { Elementos } \\
\text { da Economia } \\
\text { Circular }\end{array}$ & Evidências & $\begin{array}{l}\text { Unidades de análise } \\
\text { (UA) ou agentes } \\
\text { participantes (AP) }\end{array}$ & $\begin{array}{l}\text { Fontes de } \\
\text { evidências }\end{array}$ \\
\hline \multirow[t]{7}{*}{$\begin{array}{l}\text { Gestão do } \\
\text { fluxo de } \\
\text { renováveis e } \\
\text { de estoques }\end{array}$} & \multirow[t]{5}{*}{$\begin{array}{l}\text { Conservação do } \\
\text { capital natural }\end{array}$} & $\begin{array}{l}\text { Redução do consumo de } \\
\text { insumos por meio de } \\
\text { indicadores ambientais nos } \\
\text { processos. }\end{array}$ & $\begin{array}{l}\text { UA Remanufatura e } \\
\text { AP concessionárias }\end{array}$ & $\begin{array}{l}\text { Documentação, } \\
\text { registros em } \\
\text { arquivos, entrevistas } \\
\text { e observação direta. }\end{array}$ \\
\hline & & $\begin{array}{l}\text { Reciclabilidade do } \\
\text { caminhão. }\end{array}$ & UA Desenvolvimento & Documentação. \\
\hline & & $\begin{array}{l}\text { Desmontabilidade do } \\
\text { caminhão. }\end{array}$ & UA Desenvolvimento & $\begin{array}{l}\text { Documentação e } \\
\text { entrevistas. }\end{array}$ \\
\hline & & Testes do diesel de cana. & UA Desenvolvimento & Documentação. \\
\hline & & $\begin{array}{l}\text { Fabricação do caminhão } \\
\text { conforme a necessidade do } \\
\text { cliente, reduzindo } \\
\text { obsolescência e aumentando } \\
\text { o tempo de uso. }\end{array}$ & AP Manufatura & Entrevistas. \\
\hline & \multirow[t]{2}{*}{ Desmaterialização } & $\begin{array}{l}\text { Redução de peso do motor } \\
\text { OM } 654 \text {. }\end{array}$ & UA Desenvolvimento & Documentação \\
\hline & & $\begin{array}{l}\text { Virtualização por meio de } \\
\text { e-commerce de peças. }\end{array}$ & $\begin{array}{l}\text { UA Loja Virtual de } \\
\text { Peças }\end{array}$ & $\begin{array}{l}\text { Documentação e } \\
\text { entrevistas. }\end{array}$ \\
\hline \multirow[t]{5}{*}{ Ciclo técnico } & Manutenção & $\begin{array}{l}\text { Planos de manutenções } \\
\text { preventivas e manutenções } \\
\text { em ambientes com controle } \\
\text { operacional. }\end{array}$ & $\begin{array}{l}\text { UA Programa } \\
\text { ServicePlus, Programa } \\
\text { Service24h e AP } \\
\text { concessionárias }\end{array}$ & $\begin{array}{l}\text { Documentação, } \\
\text { registros em } \\
\text { arquivos e } \\
\text { entrevistas. }\end{array}$ \\
\hline & \multirow[t]{2}{*}{$\begin{array}{l}\text { Reuso e } \\
\text { redistribuição }\end{array}$} & $\begin{array}{l}\text { Serviço de compra e venda } \\
\text { de seminovos. }\end{array}$ & $\begin{array}{l}\text { UA SelecTrucks e } \\
\text { centros de reciclagem } \\
\text { veicular e } \\
\text { reaproveitamento de } \\
\text { peças. }\end{array}$ & Documentação. \\
\hline & & $\begin{array}{l}\text { Reuso de peças e } \\
\text { componentes entre áreas } \\
\text { dentro da companhia. }\end{array}$ & $\begin{array}{l}\text { UA Desenvolvimento, } \\
\text { Remanufatura e AP } \\
\text { manufatura. }\end{array}$ & Entrevistas. \\
\hline & Remanufatura & $\begin{array}{l}\text { Remanufatura de peças e } \\
\text { componentes do caminhão. }\end{array}$ & UA Remanufatura. & $\begin{array}{l}\text { Documentação, } \\
\text { registros em } \\
\text { arquivos, } \\
\text { entrevistas e } \\
\text { observação direta. }\end{array}$ \\
\hline & Reciclagem & $\begin{array}{l}\text { Reciclagem de resíduos dos } \\
\text { processos, de peças e } \\
\text { componentes sem condições } \\
\text { de reuso ou remanufatura, e } \\
\text { reciclagem de peças e } \\
\text { componentes do caminhão } \\
\text { em final de vida. }\end{array}$ & $\begin{array}{l}\text { UA Remanufatura, AP } \\
\text { concessionárias e } \\
\text { centros de reciclagem } \\
\text { veicular e } \\
\text { reaproveitamento de } \\
\text { peças. }\end{array}$ & $\begin{array}{l}\text { Documentação e } \\
\text { entrevistas. }\end{array}$ \\
\hline \multirow[t]{2}{*}{ Externalidades } & $\begin{array}{l}\text { Externalidade } \\
\text { positiva }\end{array}$ & $\begin{array}{l}\text { Disponibilização de } \\
\text { remanufaturados em } \\
\text { concessionárias. }\end{array}$ & $\begin{array}{l}\text { UA Remanufatura e } \\
\text { AP concessionárias }\end{array}$ & Entrevistas. \\
\hline & $\begin{array}{l}\text { Externalidade } \\
\text { negativa }\end{array}$ & $\begin{array}{l}\text { Controles operacionais em } \\
\text { processos, testes do diesel } \\
\text { de cana e tecnologia } \\
\text { BlueTec5. }\end{array}$ & UA Desenvolvimento & $\begin{array}{l}\text { Documentação e } \\
\text { entrevistas. }\end{array}$ \\
\hline
\end{tabular}

Fonte: Autor

As entrevistas ocorreram apenas em unidades de análise. A coleta de dados em agentes participantes ocorreu por meio de documentos públicos. 


\subsubsection{Evidências dos elementos da subcategoria gestão de fluxo de renováveis e de estoques.}

Atividades envolvendo a gestão de fluxo de materiais renováveis e de estoque (EMF, 2015) foram evidenciadas, tanto em processos quanto no caminhão. Elementos da Economia Circular relacionados aos processos foram identificados na unidade de análise Remanufatura e nas concessionárias que, apesar de não serem propriedade da companhia, possuem um manual com requisitos operacionais corporativos a serem cumpridos. Evidências de elementos da Economia Circular relacionadas ao produto caminhão foram encontradas na área de Desenvolvimento, que é responsável pelo projeto dos produtos, e na Loja Virtual de Peças.

Nos processos, o capital natural pode ser constituído por bens como água, ou serviços ecossistêmicos (LIU et al., 2010). Os indicadores ambientais e as metas para redução de consumo energético e de insumo, nos processos da Remanufatura e das concessionárias, são evidências do elemento de conservação do capital natural, já que estão em seu escopo, por exemplo, o consumo de água e de outros bens provenientes do meio ambiente.

Em relação ao produto, foi possível mostrar que, em razão dos tipos de materiais utilizados, aproximadamente $90 \%$ do caminhão é reciclável, possibilitando que componentes em final de vida possam retornar para o mesmo setor, como um circuito fechado, ou para outros segmentos de negócio, como um circuito aberto (THORMARK, 2002), o que reduz o consumo de matéria-prima virgem na fabricação de novas peças e componentes (CAMPOS et al., 2009). Os metais são os materiais mais utilizados no caminhão e, em grande parte, são provenientes de processos de reciclagem de sucatas, mas não há um indicador do percentual do metal utilizado que é reciclado ou que é virgem.

A característica de desmontabilidade de componentes, como o câmbio e o motor, facilita tanto a reutilização de peças (GU et al., 1997) como aumenta o potencial de remanufatura, já que não há necessidade de processos como corte a laser para remanufaturar ou restaurar peças que são partes de componentes maiores. Outro benefício da desmontabilidade é a geração de empregos e receita (WILLIAMS et al., 2008), cujo exemplo é tanto a estrutura produtiva da remanufatura, que emprega mais de cem colaboradores, quanto a cadeia logística gerada no processo de retorno de peças e componentes.

Durante o estudo, foi possível evidenciar uma iniciativa de reciclabilidade e a desmontabilidade do produto na cadeia de suprimentos, por meio de um caderno técnico com requisitos para fornecedores de peças e componentes. Tal caderno é preparado e emitido sempre que são instalados na companhia novos processos produtivos ou novos produtos, solicitando 
que os materiais fornecidos tenham design para a reciclagem e para a desmontagem, o que contribui para as atividades de serviços da estrutura de pós-vendas da companhia e para o tratamento do veículo em final de vida (VILLALBA et al., 2004).

O diesel de cana, que foi testado pela unidade de análise Desenvolvimento, além de reduzir as externalidades negativas do caminhão, provenientes das emissões atmosféricas durante seu uso, representa o elemento da Economia Circular conservação do capital natural, uma vez que é um combustível proveniente de uma fonte renovável em vez de uma fonte fóssil, sendo capaz de produzir fluxos produtivos sustentáveis (WACKERNAGEL; REES, 1997). No entanto, o combustível continua em fase de testes e não é vendido nos postos de abastecimento em escala comercial.

Considerando que o caminhão não é um produto fabricado de forma padronizada, como um automóvel tradicional, sendo produzido conforme as necessidades dos clientes, sua obsolescência é menor e seu tempo de uso é maior. Nas atividades de pós-vendas realizadas pelas unidades de análise, como manutenções preventivas (BEVILACQUA; BRAGLIA, 2000) e remanufatura (LUND, 1983) de câmbios e motores, esse tempo de uso é ainda maior, promovendo inclusive a circularidade de peças e componentes, o que reduz o impacto ambiental, devido ao estabelecimento de uma gestão de peças em circuito fechado durante a fase de uso do produto. Como resultado, a durabilidade do produto na cadeia é maior, estabelecendo a circularidade de seus materiais (EMF, 2015) e potencializando seu valor de utilidade (BOULDING, 1966; STAHEL; REDAY-MULVEY, 1981; EMF, 2015).

Dentro do elemento Desmaterialização está a redução de peso por meio da menor inserção de materiais em produtos (HINTERBERGER; SCHIMIDT-BLEEK, 1999). Na unidade de análise Desenvolvimento, foi evidenciada a iniciativa de redução de peso de um motor em 18\% graças a um design com menos materiais, o que representa uma desmaterialização (AYRES, 1997; EMF, 2015). Como resultados ambientais, foi reduzida nos processos a quantidade de matéria-prima demandada para a manufatura de peças para compor o motor, e no caminhão o consumo de combustível e as emissões atmosféricas durante seu uso.

Sobre o caminhão em final de vida, a área de DfE possui um grupo que trabalha com o planejamento de desmontabilidade e reciclabilidade. No entanto, apesar de terem sido identificados trabalhos envolvendo a circularidade de materiais, principalmente na fase de uso do produto, não foram evidenciadas iniciativas práticas por parte da companhia para o tratamento dos veículos inteiros em final de vida (OLIVEIRA; SILVA, 2011). As opções para veículos nesse estado, apresentadas no trabalho, são de centros de reaproveitamento e reciclagem de peças e componentes, que trazem benefícios tanto ambientais quanto econômicos 
para a cadeia veicular, já que proporcionam redução de descarte de resíduos, criação de empregos e oferta de materiais que podem estar escassos durante os processos de fabricação (SHARMA et al., 2016).

A virtualização é uma das ações para iniciar o processo de transição para a Economia Circular (LEWANDOWSKI, 2016), e evidências foram encontradas na unidade de análise Loja Virtual de Peças. Mesmo não substituindo áreas físicas, pois ela tem como função ser um novo canal de vendas de peças por meio de uma plataforma de e-commerce, a loja virtual de peças reduz estoques de peças em concessionárias e o deslocamento de clientes, que podem consultar na plataforma a disponibilidade das peças. A Loja Virtual de Peças também é um meio de divulgar as peças remanufaturadas, que podem ser adquiridas na troca de peças usadas.

\subsubsection{Evidências dos elementos da subcategoria ciclo técnico.}

Evidências de elementos da Economia Circular na subcategoria ciclo técnico foram encontradas nas unidades de análise Programa ServicePlus, Programa Service24h, Selectrucks e Remanufatura.

Na primeira hierarquia de tratamento de materiais, no ciclo técnico da Economia Circular, está a Manutenção. As unidades de análise Programa ServicePlus e Programa Service24h mostraram evidências, principalmente, do elemento manutenção. A manutenção preventiva é baseada na confiabilidade dos componentes (BEVILACQUA; BRAGLIA, 2000) e, com os níveis de reparação e desgaste permissíveis de peças e componentes, estabelecidos pela unidade de análise Desenvolvimento, são criados os planos de manutenção preventiva dos caminhões. Quando as manutenções são aplicadas conforme os planos, os caminhões possuem um tempo de parada menor e um tempo de uso maior. O compartilhamento (BARDHI; ECKHARDT, 2012; EMF, 2015) não é um dos elementos de loop da estrutura de Economia Circular apresentados no Referencial Teórico. No entanto, foi considerado na relação de elementos adequados ao estudo, já que o compartilhamento do produto é uma tendência do setor automotivo, e envolve a circularidade entre usuários. O compartilhamento trata de práticas que não envolvem a transferência de propriedade de um bem, mas a transferência da possibilidade de uso, estabelecendo circularidade entre usuários (BARDHI; ECKHARDT, 2012). Na Alemanha, a companhia é uma das pioneiras em compartilhamento de automóveis; já no Brasil não foi evidenciada tal prática por parte da empresa.

$\mathrm{Na}$ segunda hierarquia de tratamento de materiais, no ciclo técnico da Economia Circular, está a reutilização (EMF, 2015), que, como não trata da transformação do produto 
(AL-SALEM; LETTIERI; BAEYENS, 2009) por meio de processos produtivos, mas de sua circularidade enquanto tiver condições de uso (OLIVEIRA; SILVA, 2011), é preferível à reciclagem. $\mathrm{O}$ reuso de produtos com diversas partes, que é o caso de um caminhão, deve considerar em seu projeto características para possibilitar seu reuso (KIMURA et al., 2001) e sua desmontagem, visando a recuperação das peças (BRISSAUD; TICHKIEWITCH; ZWOLINSKI, 2006). Considerando que a SelecTrucks é uma prestadora de serviços de compra e venda de caminhões seminovos, a unidade de análise pode ser considerada um meio de reuso, onde o cliente pode entregar seu caminhão usado e adquirir um seminovo, por meio de um fluxo entre usuário e prestador de serviços. O caminhão usado passa por manutenção, podendo, se for da marca da empresa, utilizar peças remanufaturadas. Nesse caso, as peças e componentes usados do caminhão são enviados para a unidade de análise Remanufatura, e passam por um processo de avaliação. Conforme as condições das peças, elas podem ser reutilizadas sem alterações nos componentes remanufaturados, retornando à SelecTrucks para serem inseridas nos caminhões seminovos. Dentro da companhia, foi possível evidenciar o reuso de peças de componentes entre setores (OLIVEIRA; SILVA, 2011). Na área de manufatura e na unidade de análise Desenvolvimento, peças obsoletas ou descartáveis, por apresentarem problemas de qualidade, em vez de serem sucateadas são enviadas para a unidade de análise Remanufatura, sendo avaliadas e utilizadas como entrada no processo. Esse é também um princípio do waste is food (HOWER, 2016), em que o rejeito de um processo é utilizado como entrada de outro. Os centros de reaproveitamento de peças e componentes veiculares também são exemplos da segunda hierarquia de tratamento de materiais, no ciclo técnico da Economia Circular. Neles, após a descontaminação dos veículos por meio da retirada de fluidos, peças são avaliadas e, estando em boas condições, são reaproveitadas, retornando ao mercado sem necessidade de processamento (AL-SALEM; LETTIERI; BAEYENS, 2009), como na reciclagem.

A remanufatura é a penúltima hierarquia de tratamento de materiais (EMF, 2015). Além de trazer benefícios ambientais, a atividade é lucrativa, graças à comercialização de remanufaturados, e gera empregos (PRESTON, 2012), em seu processo e na cadeia logística. Elementos de remanufatura foram identificados na unidade de análise Remanufatura da planta de Campinas da companhia, onde o processo é realizado. $\mathrm{Na}$ unidade, diversas peças e componentes são transformados para a condição de novos (KERR; RYAN, 2001), seguindo as etapas de inspeção, desmontagem, limpeza, substituição ou remodelação de peças, remontagem e testes (BRISSAUD; TICHKIEWITCH; ZWOLINSKI, 2006). Os produtos resultantes são enviados para outras unidades de análise como base de troca e, com isso, realiza-se a logística reversa de peças e componentes usados, evidenciando assim uma cadeia circular (GUIDE, 2000). 
O último tratamento de materiais do ciclo técnico da Economia Circular é a reciclagem. Seu fluxo consiste na saída do material do usuário para novos processos, substituindo matérias-primas virgens (EMF, 2012). Nos processos da companhia, os resíduos não perigosos provenientes de insumos são enviados para reciclagem em companhias parceiras, especializadas em cada tipo de material. Os resíduos perigosos também são reciclados, mas são transformados por meio de um circuito aberto (THORMARK, 2002), em combustível de fornos de cimento, num processo chamado coprocessamento, o que caracteriza um downcycling (ALI; KHAIRUDDIN; ABIDIN, 2013). Os resíduos comuns sem potencial de reciclagem, ou por questões tecnológicas ou por dificuldade de encontrar parcerias especializadas em sua reciclagem, são enviados para aterros regulamentados pelos órgãos ambientais. A reciclagem envolvendo peças e componentes do caminhão foi identificada nos processos de manutenção em concessionárias, de manutenção na SelecTrucks, e de remanufatura. Peças e componentes do produto, sem condições de uso ou remanufatura, são reciclados da mesma forma que ocorre nos processos da companhia. Partes recicláveis são enviadas para empresas especializadas nessa técnica, resíduos perigosos são coprocessados (ALI; KHAIRUDDIN; ABIDIN, 2013), e resíduos comuns são enviados para aterros. Apesar das evidências de reciclagem de peças e componentes, o tratamento do caminhão inteiro em final de vida não é realizado pela companhia. Nesse caso, foram encontradas evidências em dados secundários, sendo descritos os centros de reciclagem de peças e componentes veiculares, que descontaminam, desmontam e reciclam as peças e componentes dos veículos em final de vida, estabelecendo assim a última alternativa de circularidade para os materiais, na estrutura da Economia Circular (EMF, 2015).

\subsubsection{Evidências dos elementos da subcategoria externalidades.}

As externalidades (PIGOU, 1932; COASE, 1960; BLACK, 1997; DEAN; MCMULLEN, 2007; EMF, 2015) do estudo envolvem tanto os processos quanto o produto caminhão. Levantamentos de aspectos e impactos ambientais foram identificados na Remanufatura. Os aspectos ambientais inerentes às oficinas de concessionárias e da SelecTrucks também foram levantados pela companhia, o que contribuiu para a criação dos requisitos estabelecidos para as atividades de manutenção, envolvendo principalmente a gestão de seus resíduos. Como resultado do levantamento dos aspectos ambientais, foram estabelecidos controles operacionais que auxiliaram na redução de externalidades negativas inerentes aos processos da Remanufatura, SelecTrucks e manutenções. Em relação ao produto, como a área de Desenvolvimento já conhece as emissões atmosféricas do caminhão durante seu 
uso, foi possível evidenciar atividades dessa unidade de análise para reduzir as externalidades negativas provenientes das emissões (DEAN; MCMULLEN, 2007) e, no estudo, foram apresentados o diesel de cana e a tecnologia BlueTec5 que, quando operados juntos, proporcionam uma redução nas emissões de hidrocarbonetos, óxido de nitrogênio, monóxido de carbono, dióxido de carbono e material particulado do caminhão.

Pelo fato de a aquisição de peças e componentes remanufaturados ser possível apenas em concessionários, houve um incentivo para a realização de manutenções dos caminhões em suas oficinas, que possuem controle operacional e requisitos ambientais da companhia. Como resultado, os impactos provenientes das atividades de manutenção, como possíveis vazamentos de óleo em redes pluviais e descarte de resíduos em locais inadequados, que podem atingir agentes não envolvidos na cadeia do caminhão, são reduzidos. Tal cenário pode ser caracterizado como uma externalidade positiva (BLACK, 1997; DEAN; MCMULLEN, 2007).

\subsubsection{A hierarquia do ciclo técnico da Economia Circular na cadeia do caminhão.}

Para ilustrar a presença dos elementos do ciclo técnico (EMF, 2015), que são as hierarquias de tratamento de materiais, a Figura 32 apresenta uma cadeia de valor do caminhão da companhia, simplificada, e os elementos envolvidos em cada agente, considerando a circularidade das peças e componentes do produto. Os agentes são: o Desenvolvimento, a Manufatura, as Concessionárias e a SelecTrucks, a Remanufatura e os Centros de reciclagem e reaproveitamento de peças e componentes.

Figura 22 - A hierarquia do ciclo técnico da EC na cadeia do caminhão.

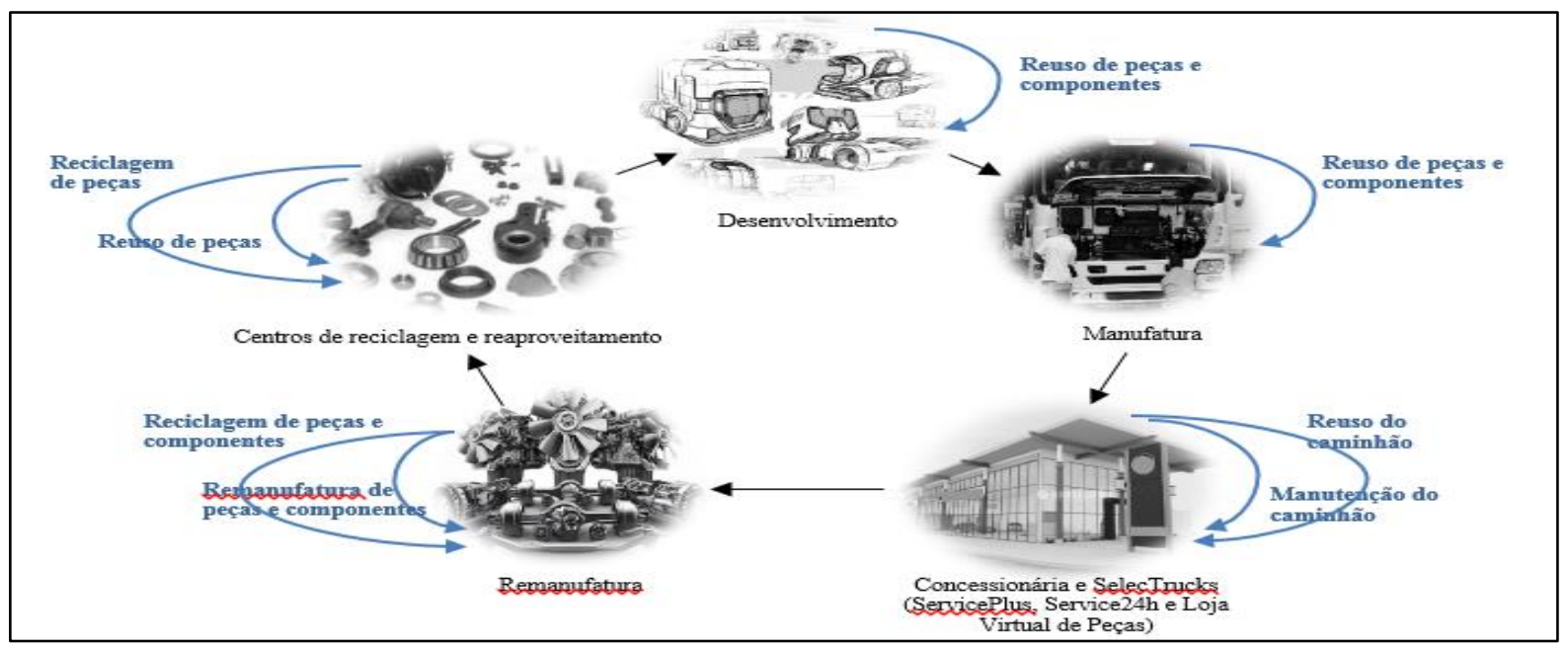

Fonte: Autor 
O Desenvolvimento e a manufatura reusam (KIMURA et al., 2001; BRISSAUD; TICHKIEWITCH; ZWOLINSKI， 2006; AL-SALEM; LETTIERI; BAEYENS， 2009; AMELIA et al., 2009; OLIVEIRA; SILVA, 2011) as peças que compõem componentes obsoletos ou com falhas de qualidade na Remanufatura, evitando assim o sucateamento para empresas de reciclagem. As concessionárias, por meio dos Programas ServicePlus, Service24h e da Loja Virtual de Peças, comercializam e realizam manutenções preventivas e corretivas (ABNT, 1994; BEVILACQUA; BRAGLIA, 2000) no caminhão. A SelecTrucks faz o reuso do produto, considerando a compra de usados, a realização de reparos e a venda como seminovos. A Remanufatura realiza a avaliação e a remanufatura (LUIND, 1983; JAYARAMAN; GUIDE JR; SRIVASTAVA, 1999; GUIDE, 2000; KEER; RYAN, 2001; SAVASKAN; BHATTACHARYA; VAN WASSENHOVE, 2004; BRISSAUD; TICHKIEWITCH; ZWOLINSKI, 2006; ATASU et al., 2008; AMELIA et al., 2009; ZHANG et al., 2011; AGRAWAL; ATASU; VAN ITTERSUM, 2015; ZHANG; CHEN, 2015; DIENER; TILLMAN, 2015) de peças e componentes e, quando não estão em condições devido a desgaste ou quebra, encaminha-os para reciclagem (NOCI, 1995; THORMARK, 2002; FRANCHETTI; MARCONATO, 2003; KANG; SCHOENUNG, 2005; AMELIA et al.; 2009; BRASIL, 2010; CAMPOS et al., 2009; ALI et al., 2013; EMF, 2015; CUCCHIELLA et al., 2016; LELLIS FERREIRA; FARIAS FILHO; QUELHAS, 2016; LESLIE et al., 2016; SHAHBAZI et al., 2016; SOO; COMPSTON; DOOLAN, 2016), em parceiros especializados. Os centros de reciclagem e reaproveitamento, após processo de descontaminação e desmontagem, avaliam as peças e componentes e, conforme resultado da avaliação, as reaproveitam ou as encaminham para reciclagem.

Considerando os loops do Princípio 2 do Ciclo Técnico, uma ação incentivada pela Economia Circular, mas não presente na estrutura proposta pela Ellen MacArthur Foundation como um loop de materiais, é o compartilhamento, que poderia ser enquadrado como prioridade da hierarquia de circularidade de materiais, promovendo a maximização do uso ao compartilhar o valor de utilidades do bem de consumo. No estudo, não foram evidenciadas iniciativas de compartilhamento da companhia no Brasil, mas considerando publicações de casos de sucesso, é possível concluir que esse é um modelo a ser explorado pelo segmento da indústria de veículos no país. Locação, leasing e até arrendamento são exemplos de ações de compartilhamento de caminhões já praticadas em alguns países, incluindo o Brasil, mas em pequena escala e não por grandes empresas de veículos. A virtualização e o compartilhamento são práticas que têm sido operacionalizadas juntas, devido à abrangência da divulgação proporcionada por canais virtuais, e à facilidade de conectividade de pessoas, estabelecendo assim a circularidade dos 
materiais entre usuários. Aplicativos de carona ou de locação de quartos de residências são exemplos de compartilhamento que utilizam a virtualização.

A manutenção, que é um loop da Economia Circular, pode ser preventiva ou corretiva. Evidências mostraram que a manutenção preventiva aumenta o tempo de uso dos produtos, e possibilitaria inclusive um aumento no compartilhamento de valor dos materiais, podendo estar vinculada ao loop do compartilhamento. Esses dois elementos, quando praticados juntos, aumentariam a circularidade do material no primeiro loop. A manutenção corretiva, por sua vez, apesar de não ser tão benéfica ao valor de utilidade do material e ao meio ambiente quanto a preventiva, também estende o tempo de uso do produto antes do alcance do próximo loop da economia circular, que é o reuso. Assim, o primeiro loop da economia circular poderia ser o compartilhamento e a manutenção preventiva, integrados, seguidos pela manutenção corretiva no segundo loop.

Ainda em relação aos loops da estrutura da Economia Circular proposta pela Ellen MacArthur Foundation, a última hierarquia é a reciclagem. No estudo, foram vistas evidências de reciclagem nos processos das unidades de análise, sendo que, quando não contaminados, os materiais geraram receita para a companhia, podendo passar por processamentos de upcycling, e, quando contaminados, geraram custos em um processo de downcycling. Considerando os benefícios ambientais e econômicos do upcycling em comparação ao downcycling, o loop de reciclagem da Economia Circular poderia ser dividido para priorizar o upcycling.

Figura 23 - Proposta de novos loops na estrutura da Economia Circular.

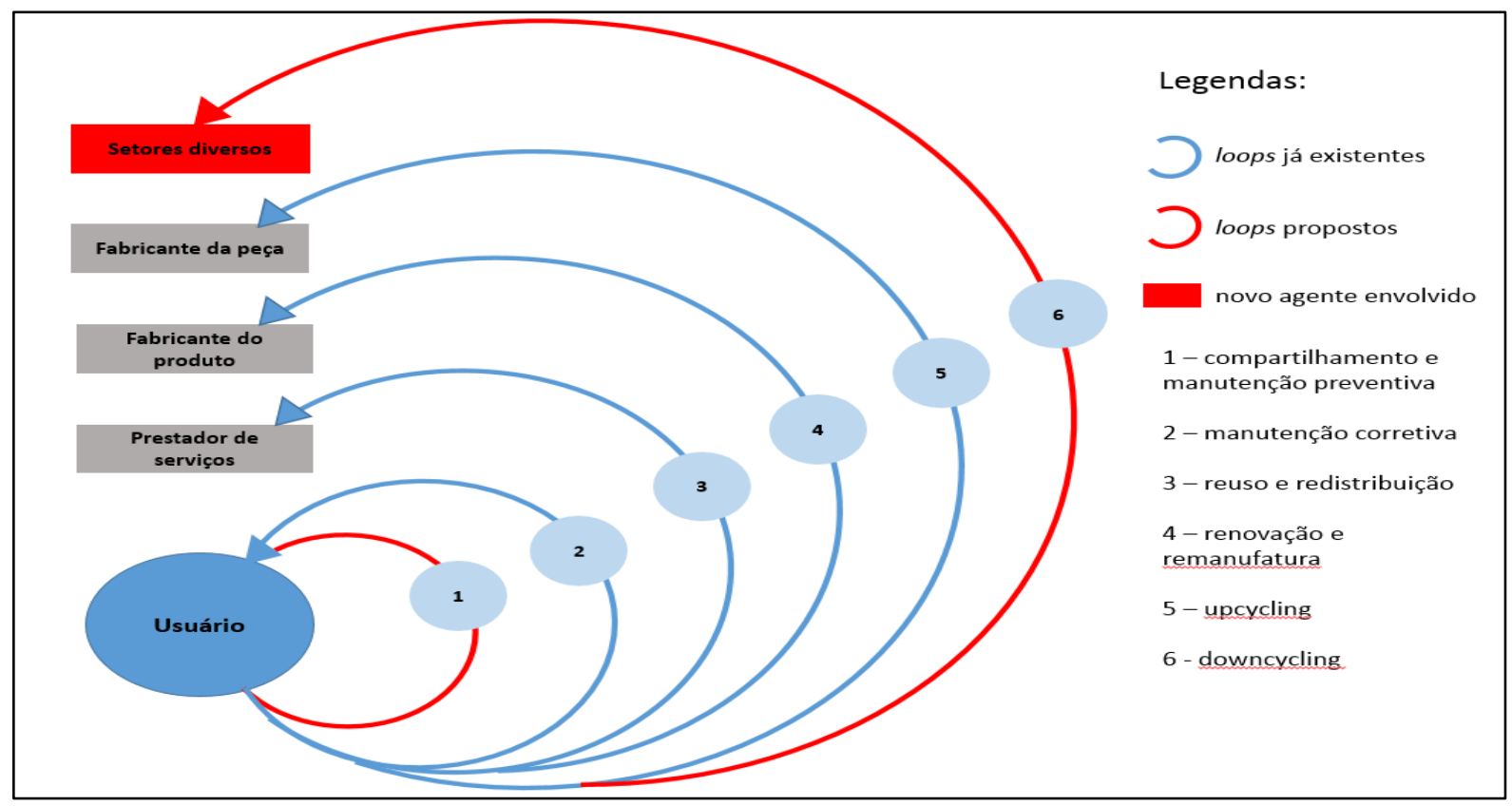

Fonte: Autor, adaptado de EMF, 2015. 
Com as separações dos loops de manutenção e de reciclagem, bem como a inserção do compartilhamento na hierarquia de tratamento de materiais, o tempo de uso do produto e o valor de utilidade do material podem ser aumentados. 


\section{CONCLUSÃO}

O objetivo desta pesquisa foi analisar a aplicação dos princípios da Economia Circular na cadeia de valor do caminhão da indústria de veículos comerciais. As unidades de análise escolhidas são setores ou processos da companhia que contribuem para a circularidade de peças e componentes, e fazem parte ou da estrutura de Desenvolvimento do Produto ou de PósVendas de caminhões. Essas unidades são: o Desenvolvimento, responsável pelo projeto dos caminhões; a Loja Virtual de Peças, que é uma plataforma de e-commerce de peças; o Programa ServicePlus, que é um plano de manutenção preventiva; o Programa Service24h, que é um plano de assistência técnica de campo; a SelecTrucks, que é uma loja de comercialização de caminhões seminovos; e a Remanufatura, que reindustrializa peças e componentes da marca.

Apesar de as ações voltadas para a circularidade de materiais do estudo de caso visarem o aumento da receita da companhia, diversos benefícios ambientais foram gerados como consequência. Por meio das evidências encontradas no estudo, foi possível verificar elementos dos princípios da Economia Circular em diferentes etapas da cadeia do caminhão, envolvendo tanto processos de pós-vendas quanto o produto em si.

No Princípio 1 da Economia Circular, está a subcategoria de gestão de fluxos renováveis e de estoques. Os elementos levantados no Referencial Teórico de conservação do capital natural e desmaterialização foram adequados para: insumos renováveis e não renováveis nos processos, matéria-prima do caminhão, combustíveis compatíveis do caminhão, reciclabilidade do caminhão e desmontabilidade do caminhão.

O elemento de conservação do capital natural foi identificado tanto nos processos quanto no produto. Nos processos, ele foi evidenciado nas metas dos indicadores de desempenho ambiental, que são aplicadas na Remanufatura, nas concessionárias e na SelecTrucks. No produto, uma das evidências é a remanufatura que, em função de sua aplicação, reduz o consumo de matéria-prima virgem para peças e componentes, que podem ser demandados em processos de manutenção do caminhão. Outra evidência é o teste com o diesel de cana, uma vez que é um combustível proveniente de fontes renováveis.

Por estar diretamente envolvida no design do produto, a área de Desenvolvimento possui grande parte de suas evidências relacionadas ao Princípio 1. A reciclabilidade e a desmontabilidade estabelecidas no projeto do caminhão proporcionaram a reciclagem de grande percentual do veículo, e a aplicação da remanufatura em diversas peças e componentes do produto. Grande parte do caminhão é feita de metal, o que contribui também para a reciclabilidade. A redução de peso do motor OM 654 caracteriza uma iniciativa de 
desmaterialização, que contribuiu tanto para a redução do consumo de matéria-prima quanto das emissões do caminhão durante seu uso.

O elemento da virtualização, que ainda faz parte do Princípio 1, foi evidenciado na Loja Virtual de Peças, que é uma plataforma de e-commerce em que clientes podem adquirir peças e componentes sem a necessidade de deslocamento. Por ser uma estratégia complementar de vendas, e não substitutiva dos canais tradicionais, não houve redução na quantidade de lojas físicas de vendas. No entanto, reduziu-se a quantidade de estoques de peças com baixo giro de venda em concessionárias. Adicionalmente, a Loja Virtual é um canal de divulgação de peças e componentes remanufaturados. Portanto, houve benefícios ambientais, tanto no aspecto de estoque e armazenamento de peças de baixo giro, o que gera consumo de espaço físico e mão de obra para sua movimentação, quanto na promoção da divulgação dos produtos provenientes da unidade de análise Remanufatura.

Evidências sobre o percentual de uso de materiais reciclados no caminhão não foram percebidas. Apesar de haver um manual de desenvolvimento que permite o uso de materiais reciclados para determinadas peças, e ser de conhecimento da empresa que parte dos metais utilizados no produto é proveniente de peças sucateadas e não de matéria-prima virgem, não há uma estimativa de quantas peças utilizadas são recicladas. Para fechar a cadeia da Economia Circular, considerando o retorno dos materiais provenientes do último loop, que é a reciclagem, o uso de materiais reciclados no produto deve ser não apenas considerado, mas priorizado sempre que possível, evitando assim o consumo de novos recursos naturais em sua cadeia de valor.

Os elementos do Princípio 2 do Referencial Teórico trazem os loops dos materiais em seu ciclo de uso, tendo como tratamentos de circularidade a manutenção, o reuso e a redistribuição, a remanufatura e a reciclagem. No estudo, os elementos foram adequados e separados entre processos e produtos. Os planos de manutenção preventiva auxiliam no funcionamento do caminhão, aumentando seu tempo de uso e diminuindo suas falhas, o que traz benefícios ambientais se comparados às manutenções corretivas, que geram resíduos de forma não planejada, e até quebras, que podem ocorrem em ambientes sem controles operacionais, como contenções e destinação de fluidos e outros resíduos. As manutenções preventivas ocorrem em concessionárias, que seguem requisitos da companhia em termos de gestão de resíduos, metas de desempenho ambiental e coleta seletiva. Os resíduos gerados no processo são previstos conforme o tipo de manutenção, possibilitando o planejamento da destinação de cada tipo de material. Com o plano de assistência técnica de campo auxiliando nas atividades de reparo, os produtos com problemas técnicos podem passar por manutenção 
no local da falha ou serem encaminhados para alguma concessionária próxima, dependendo da complexidade. Tal medida evita, inclusive, o reparo em locais paralelos, sem controles operacionais adequados.

O envio das peças obsoletas ou com problemas de qualidade, provenientes de veículos de testes ou do processo de manufatura, para a unidade de análise Remanufatura representa o elemento de reuso da Economia Circular, que é a segunda hierarquia para tratamento de materiais. Tal reuso evita que materiais provenientes dessas peças e componentes sejam sucateados. Apesar de o sucateamento ser um destino em que o material metálico é reciclado, o reuso é preferível, por não exigir processos que demandem grandes quantidades de insumos, além de não gerar perda de qualidade nas características do material, inerente ao processo de reciclagem. Outra evidência de reuso foi vista na loja de comercialização de caminhões seminovos, que é um exemplo de servitização e do loop de reuso e redistribuição da Economia Circular. Nesta unidade de análise, quando há negociação com um caminhão usado da marca, existe a possibilidade de uso de peças e componentes remanufaturados, adquiridos preferencialmente por meio de um sistema de troca com as peças usadas, promovendo assim um fluxo de logística reversa de materiais.

A penúltima hierarquia de tratamento de materiais é representada pelo processo de Remanufatura, que possui relação com todas as outras unidades de análise do estudo. Com a operação de Remanufatura, recursos naturais deixam de ser extraídos devido ao processo de reindustrialização de peças e componentes usados. A logística reversa também é promovida, uma vez que os remanufaturados são disponibilizados de preferência como base de troca de usados, fazendo com que clientes deem preferência a reparos em concessionárias, que é o canal de distribuição dos remanufaturados para usuários.

A reciclagem, que é a última alternativa de tratamento de materiais, foi evidenciada nos processos e no produto. Os rejeitos de insumos, como estopas com óleo ou fluidos contaminantes, são direcionados para empresas de reciclagem, podendo ser transformados em novos produtos por meio do upcycling, ou em compostos para combustíveis por meio do downcycling. As peças e componentes do produto, que não possuem mais condições de ser remanufaturados, são sucateados e também reciclados, retornando como matéria-prima de novos processos. As evidências de reciclagem do caminhão inteiro foram obtidas de dados secundários, sendo os centros de reciclagem veicular e o reaproveitamento de peças o destino ambientalmente adequado.

O Princípio 3 tem como elementos do Referencial Teórico as externalidades positivas e negativas, que também foram separadas no estudo entre processos e produto. Pelo fato de o 
canal de aquisição de peças e componentes remanufaturados pelo cliente ser o concessionário, há um incentivo para a realização de reparos em oficinas das concessionárias, que possuem controle operacional, gestão de resíduos e metas ambientais, que são requisitos da companhia. Considerando que externalidades são efeitos sociais, econômicos e ambientais indiretamente causados por um produto ou serviço, e que, em razão do incentivo aos clientes para realizar manutenções dos caminhões em locais ambientalmente controlados para evitar impactos ambientais indesejados a terceiros, foi possível evidenciar que o resultado do processo gera uma externalidade positiva. Reduções das externalidades negativas foram evidenciadas em diversos momentos do estudo, sendo relacionadas aos processos, por meio dos controles ambientais e das metas de redução de consumo de insumos, e, ao caminhão, com iniciativas de redução de emissões atmosféricas na fase de uso e estabelecimento de circularidade dos materiais nas atividades de pós-vendas, exemplificadas como iniciativas do Princípio 2 da Economia Circular.

As unidades de análise foram criadas pela companhia principalmente para o aumento de sua receita, suprindo a necessidade de clientes, e para o cumprimento de requisitos legais. $\mathrm{O}$ aperfeiçoamento de atividades de pós-vendas é uma tendência no setor e a Política Nacional de Resíduos Sólidos é um agente impulsionador para o desenvolvimento de iniciativas para a reciclagem de peças e componentes.

As evidências dos elementos da Economia Circular mostram não apenas benefícios ambientais, que foram o foco do trabalho, mas também sociais e econômicos. No caso estudado, a Remanufatura emprega mais de cem colaboradores. A cadeia logística proveniente do transporte de remanufaturados e usados também gera empregos. Financeiramente, as atividades de pós-vendas, voltadas para a aplicação de serviços nos caminhões durante a fase de uso, geraram um aumento de receita para a companhia, mostrando que a servitização não é apenas uma alternativa, mas uma inclinação do setor para aumentar a lucratividade por meio da prestação de serviços. Assim, este pode ser um caminho para o setor de veículos crescer, considerando as novas tendências e demandas do mercado.

Apesar das evidências encontradas no estudo de caso, ainda há muito a ser feito pela companhia para se desenvolver uma estrutura completa de Economia Circular. Devem ser considerados todos os loops dos materiais nos processos e na cadeia do caminhão, havendo uma sincronia clara entre cada hierarquia de tratamento de materiais. Adicionalmente, para o funcionamento desse novo modelo econômico, é preciso desenvolver uma forma consciente de consumo de bens, compartilhando a responsabilidade sobre os impactos das cadeias de produção e consumo. Neste cenário, o governo seria um agente criador de incentivos para ações 
de Economia Circular, os produtores, responsáveis pelo desenvolvimento e vendas de bens com condições técnicas e econômicas de circularidade, e os consumidores, conscientes dos impactos de seus consumos e das possibilidades de circularidade dos materiais utilizados. A contribuição desta pesquisa foi a inserção de dois novos loops no Princípio 2 do ciclo técnico da estrutura da Economia Circular proposta pela Ellen MacArthur Foundation, formando como hierarquias: o compartilhamento e a manutenção preventiva, a manutenção corretiva, o reuso, a remanufatura, o upcycling e, por fim, o downcycling.

\subsection{LIMITAÇÕES DA PESQUISA}

Os indicadores de desempenho possibilitam a avaliação contínua da evolução dos processos da companhia. A ausência de evidências de indicadores ambientais nas atividades de pós-vendas não permitiu a quantificação dos benefícios ambientais inerentes a alguns elementos da Economia Circular identificados nas unidades de análise.

\subsection{RECOMENDAÇÕES PARA FUTURAS PESQUISAS}

O trabalho trouxe elementos para que futuras pesquisas investiguem o processo de transição das companhias de veículos, no qual as receitas, que resultavam predominantemente de volume de produção, estão tendendo para volume de serviços prestados.

Em termos sociais e econômicos, recomenda-se estudar a relação dos serviços e das vendas, verificando se a aplicação da circularidade de materiais já está compensando a queda de receita das companhias de veículos e da oferta de empregos no setor, em razão da redução de demanda por novos produtos.

O aumento da complexidade de peças e componentes, para suprir questões de qualidade, reduz a reciclabilidade dos materiais, o que é um desafio para a Economia Circular e também uma recomendação para futuras pesquisas. 


\section{REFERÊNCIAS}

ABNT - ASSOCIAÇÃO BRASILEIRA DE NORMAS TÉCNICAS, NBR 5462:

Confiabilidade e mantenabilidade. Rio de Janeiro, 1994.

ADGER, W. Neil. Social and ecological resilience: are they related?. Progress in human geography, Thousand Oaks, v. 24, n. 3, p. 347-364, set. 2000.

AEA - ASSOCIAÇÃO BRASILEIRA DE ENGENHARIA AUTOMOTIVA. Cartilha de Destinação de Materiais Veiculares AEA. 2012. Disponível em: $<$ http://aea.org.br/v1/wpcontent/uploads/2012/11/Cartilha-de-Destina $\% \mathrm{C} 3 \%$ A7\%C3\%A3o-Final-AEA.pdf $>$. Acesso em: 04 set. 2017.

AGRAWAL, Vishal V.; ATASU, Atalay; VAN ITTERSUM, Koert. Remanufacturing, thirdparty competition, and consumers' perceived value of new products. Management Science, Catonsville, v. 61, n. 1, p. 60-72, jan. 2015.

AKELLA, A. K.; SAINI, R. P.; SHARMA, Mahendra Pal. Social, economical and environmental impacts of renewable energy systems. Renewable Energy, Oxford, v. 34, n. 2, p. 390-396, set. 2009.

AL-SALEM, S. M.; LETTIERI, P.; BAEYENS, J. Recycling and recovery routes of plastic solid waste (PSW): A review. Waste Management, Oxford, v. 29, n. 10, p. 2625-2643, jun. 2009.

ALI, N. S.; KHAIRUDDIN, N. F.; ABIDIN, S. Z. Upcycling: Re-use and recreate functional interior space using waste materials. 2013. Disponível em:

$<$ https://www.designsociety.org/publication/34808/upcycling_re-use_and_recreate_functional _interior_space_using_waste_materials>. Acesso em: 05 ago. 2016.

AMAZONAS, Maurício de Carvalho. Valor ambiental em uma perspectiva heterodoxa institucional-ecológica. Economia e Sociedade, Campinas, v. 18, n. 1, p. 183-212, abr. 2016.

AMELIA, L. et al. Initiating automotive component reuse in Malaysia. Journal of Cleaner Production, Amsterdam, v. 17, n. 17, p. 1572-1579, nov. 2009.

ANDERBERG, Stefan. Industrial metabolism and the linkages between economics, ethics and the environment. Ecological Economics, Amsterdam, v. 24, n. 2, p. 311-320, fev. 1998.

ANDERSEN, Mikael Skou. An introductory note on the environmental economics of the circular economy. Sustainability Science, Heidelberg, v. 2, n. 1, p. 133-140, jan. 2007.

ANFAVEA - ASSOCIAÇÃO NACIONAL DOS FABRICANTES DE VEÍCULOS AUTOMOTORES. Anuário da Indústria Automobilística Brasileira 2015. 2015.

Disponível em: <http://www.anfavea.com.br/anuario.html>. Acesso em: 05 jun. 2016.

Anuário da Indústria Automobilística Brasileira 2017. 2017. Disponível em:

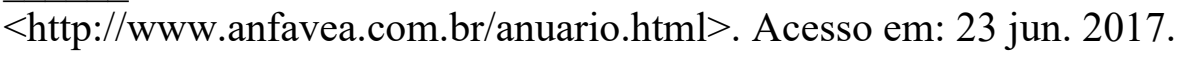


; CNI - CONFEDERAÇÃO NACIONAL DA INDÚSTRIA. Indústria

automobilística e sustentabilidade. Brasília: CNI, 2012.

ATASU, Atalay; SARVARY, Miklos; VAN WASSENHOVE, Luk N. Remanufacturing as a marketing strategy. Management Science, Catonsville, v. 54, n. 10, p. 1731-1746, ago. 2008.

AYRES, Robert U. Comments on Georgescu-Roegen. Ecological Economics, Amsterdam, v. 22, n. 3, p. 285-287, set. 1997.

Industrial metabolism: work in progress. In: VAN DEN BERGH, J. C.; HOFKES, Marjan W., Theory and Implementation of Economic Models for Sustainable Development. Rotterdam: Springer Netherlands, 1998, p. 195-228.

AZEVEDO, Juliana L. A Economia Circular Aplicada no Brasil: uma análise a partir dos instrumentos legais existentes para a logística reversa. 2015. Disponível em:

$<\mathrm{http}: / /$ www.inovarse.org/sites/default/files/T_15_036M.pdf $>$. Acesso em: 05 out. 2016.

BALANAY, Raquel; HALOG, Anthony. Charting Policy Directions for Mining's

Sustainability with Circular Economy. Recycling, Basel, v. 1, n. 2, p. 219-230, jun. 2016.

BARDHI, Fleura; ECKHARDT, Giana M. Access-based consumption: The case of car sharing. Journal of Consumer Research, Chicago, v. 39, n. 4, p. 881-898, maio 2012.

BARDIN, Laurence. Análise de conteúdo. São Paulo: Edições 70, 2011.

BARROS, Daniel Chiari; PEDRO, Luciana Silvestre. O papel do BNDES no desenvolvimento do setor automotivo brasileiro. Rio de Janeiro: BNDES, 2011, v. 1.

BELK, Russell. You are what you can access: Sharing and collaborative consumption online. Journal of Business Research, Amsterdam, v. 67, n. 8, p. 1595-1600, ago. 2014.

BENYUS, Janine M. Biomimicry: innovation inspired by nature. New York: HarperCollins/Perennial, 2002

BERRY, Michael A.; RONDINELLI, Dennis A. Proactive corporate environmental management: A new industrial revolution. Academy of Management Executive, New York, v. 12 , n. 2, p. 38-50, maio 1998.

BEVILACQUA, Maurizio; BRAGLIA, Marcello. The analytic hierarchy process applied to maintenance strategy selection. Reliability Engineering \& System Safety, Amsterdam, v. 70, n. 1, p. 71-83, out. 2000.

BICKET, M. et al. Scoping study to identify potential circular economy actions, priority sectors, material flows \& value chains. Brussels: EU Commission, 2014.

BLACK, J. Rules and regulators. Oxford: Oxford University Press, 1997.

BONVIU, Florin. The European economy: from a linear to a circular economy. Romanian Journal of European Affairs, Bucharest, v. 14, n. 1, p. 78, dez. 2014. 
BOTSMAN, R.; ROGERS, R. O que é meu é seu: como o consumo colaborativo vai mudar o mundo. Porto Alegre: Bookman, 2011.

BOULDING, K. E. The economics of coming spaceship earth. In: HENRY JARRETT, Environmental quality in a growing economy. Baltimore, MD: John Hopkins University Press, 1966.

BRAGANÇA, S. R et al. Recycling of iron foundry sand and glass waste as raw material for production of whiteware. Waste Management and Research, Thousand Oaks, v. 24, n. 1, p. 60-66, fev. 2006.

BRASIL. Conselho Nacional do Meio Ambiente. CONAMA 403/2008 - Programa de Controle da Poluição do Ar por Veículos Automotores PROCONVE P7. 2008.

Disponível em: < http://www.mma.gov.br/port/conama/legiabre.cfm?codlegi=591>. Acesso em: 22 ago. 2017.

. Ministério do Meio Ambiente. Consumo sustentável: manual de educação. Brasília: Consumers International/ MMA/ MEC/ IDEC, 2005, p. 160.

PNRS - Política Nacional de Resíduos Sólidos. 2010. Disponível em:

$<$ http://www.planalto.gov.br/ccivil_03/_ato2007-2010/2010/lei/112305.htm>. Acesso em: 28 dez. 2015.

Programa de Sustentabilidade Veicular. 2016. Disponível em:

$\overline{<\mathrm{http}: / / w w w . b r a s i l . g o v . b r / e c o n o m i a-e-e m p r e g o / 2016 / 09 / g o v e r n o-r e c e b e-p l a n o-d e-a p o i o-a o-~}$ setor-automotivo>. Acesso em: 26 jun. 2017.

BRISSAUD, Daniel; TICHKIEWITCH, Serge; ZWOLINSKI, Peggy (Ed.). Innovation in life cycle engineering and sustainable development. Berlin: Springer, 2006.

BURCHART-KOROL, Dorota; CZAPLICKA-KOLARZ, Krystyna; KRUCZEK, Mariusz. The benefits of integration of circular economy in supply chain management. 2015. Disponível em: <http://www.clc2015.cz/files/proceedings>. Acesso em: 20 nov. 2016.

CAMPOS, L. M. S. et al. A reciclagem como empreendedorismo: fonte de transformação socioeconômica e ambiental. Revista da Micro e Pequena Empresa, Campo Limpo Paulista, v. 3, n. 1, p. 3-15, jan 2009.

CASOTTI, B. P.; GOLDENSTEIN, Marcelo. Panorama do setor automotivo: as mudanças estruturais da indústria e as perspectivas para o Brasil. BNDES Setorial, Rio de Janeiro, n.28, p.147-188, set. 2008 .

CHERTOW, Marian R. Industrial symbiosis: literature and taxonomy. Annual Review of Energy and the Environment, Palo Alto, v. 25, n. 1, p. 313-337, nov. 2000.

. "Uncovering" industrial symbiosis. Journal of Industrial Ecology, Hoboken, v. 11, n. 1, p. 11-30, jan. 2007. 
CHRISTENSEN, N. L. et al. The report of the Ecological Society of America committee on the scientific basis for ecosystem management. Ecological Applications, Hoboken, v. 6, n. 3, p. 665-691, ago. 1996.

COASE, Ronald H. The problem of social cost. Journal of Law and Economics, Chicago, v. 3, n. 1, p. 1-44, out. 1960.

COLE, Raymond J. Regenerative design and development: current theory and practice.

Building Research and Information, Abingdon-on-Thames, v. 40, n. 1, p. 1-6, jan. 2012.

COLLIS, Jill; HUSSEY, Roger. Pesquisa em Administração. 2. Ed. São Paulo: Bookman, 2005.

COM - EUROPEAN COMMISSION. Council Directive 85/347/EEC of 8 July 1985 amending Directive 68/297/EEC on the standardization of provisions regarding the duty-free admission of fuel contained in the fuel tanks of commercial motor vehicles. Brussels: Council Directive, 1985.

. Directive 2000/53/EC of the European Parliament and of the Council of 18 September 2000 on End-of Life Vehicles. Official Journal of the European Union, Brussels, v. 7, n. 1, p. 34-49, set. 2000.

Towards a circular economy: a zero waste programme for Europe. Brussels: Publications Office of the European Union, 2014.

Report from the Commission to the European Parliament, the Council, the European Economic and Social Committee and the Committee of the Regions. Brussels: Publications Office of the European Union, 2017.

COSTANZA, Robert. Ecological economics: the science and management of sustainability. New York: Columbia University Press, 1992.

; DALY, Herman E. Natural capital and sustainable development. Conservation Biology, Oxford, v. 6, n. 1, p. 37-46, mar. 1992.

CRESWELL, J. W. Projeto de pesquisa: método qualitativo, quantitativo e misto. Porto Alegre: Artmed, 2010.

CUCCHIELLA, F. et al. Automotive printed circuit boards recycling: an economic analysis. Journal of Cleaner Production, Amsterdam, v. 121, p. 130-141, maio 2016.

DAG. 360 Degrees - Sustainability 2006 - FACTS. 2006. Disponível em: $<$ https://www.daimler.com/documents/investors/berichte/geschaeftsberichte/daimlerchrysler/d aimler-ir-annualreport-2006.pdf $>$. Acesso em: 26 ago. 2017.

Releases 2016. 2016. Disponível em: <https://www.daimler.com/documents/ sustainability/other/daimler-focusonsustainability-2016.pdf >. Acesso em: 26 ago. 2017.

DARNALL, Nicole; JOLLEY, G. Jason; HANDFIELD, Robert. Environmental management systems and green supply chain management: complements for sustainability?. Business

Strategy and the Environment, Hoboken, v. 17, n. 1, p. 30-45, jan. 2008. 
DEAN, Thomas J.; MCMULLEN, Jeffery S. Toward a theory of sustainable entrepreneurship: Reducing environmental degradation through entrepreneurial action. Journal of Business Venturing, Amsterdam, v. 22, n. 1, p. 50-76, jan. 2007.

DESLAURIERS J. P. Recherche qualitative: guide pratique. Québec: McGrawHill, Éditeurs, 1991.

DIENER, Derek L.; TILLMAN, Anne-Marie. Scrapping steel components for recyclingIsn't that good enough? Seeking improvements in automotive component end-of-life.

Resources, Conservation and Recycling, Amsterdam, v. 110, p. 48-60, jul. 2016.

DT. Diesel Technic Spare Parts - Truck Parts. 2017. Disponível em: $<$ https://www.dtspareparts.com>. Acesso em: 03 set. 2017.

EHRENFELD, John; GERTLER, Nicholas. Industrial ecology in practice: the evolution of interdependence at Kalundborg. Journal of Industrial Ecology, Hoboken, v. 1, n. 1, p. 67 79, jan. 1997.

EISENHARDT, Kathleen M. Building theories from case study research. Academy of Management Review, New York, v. 14, n. 4, p. 532-550, out. 1989.

; GRAEBNER, Melissa E. Theory building from cases: Opportunities and challenges. Academy of Management Journal, New York, v. 50, n. 1, p. 25-32, fev. 2007.

EL-HALWAGI, Mahmoud M.; GABRIEL, F.; HARRELL, Dustin. Rigorous graphical targeting for resource conservation via material recycle/reuse networks. Industrial and Engineering Chemistry Research, Washington, v. 42, n. 19, p. 4319-4328, ago. 2003.

ELTAYEB, Tarig K.; ZAILANI, Suhaiza; RAMAYAH, T. Green supply chain initiatives among certified companies in Malaysia and environmental sustainability: Investigating the outcomes. Resources, Conservation and Recycling, Amsterdam, v. 55, n. 5, p. 495-506, mar. 2011.

EMF - ELLEN MACARTHUR FOUNDATION. Towards the circular economy - Vol. 1: Economic and business rationale for an accelerated transition. Isle of Wight: EMF, 2012.

Towards the circular economy - Vol. 2: Opportunities for the consumer goods sector. Isle of Wight: EMF, 2013.

Towards the circular economy: Business rationale for an accelerated transition. Isle of Wight: EMF, 2015.

Case Studies. 2016. Disponível em:

$\overline{<\mathrm{http}: / / w w w . e l l e n m a c a r t h u r f o u n d a t i o n . o r g / c a s e \_s t u d i e s>. ~ A c e s s o ~ e m: ~} 29$ dez. 2016.

FEAM - FUNDAÇÃO ESTADUAL DE MEIO AMBIENTE; FIEMG - FEDERAÇÃO DAS INDÚSTRIAS DO ESTADO DE MINAS GERAIS. Guia técnico ambiental da reparação automotiva. Belo Horizonte: FIEMG, 2016. 
FENABRAVE - FEDERAÇÃO NACIONAL DE DISTRIBUIÇÃO DE VEÍCULOS AUTOMOTORES. Anuário 2015. O desempenho da distribuição automotiva no Brasil. Disponível em: < http://www3.fenabrave.org.br >. Acesso em 05 jun. 2016.

FINKBEINER, Matthias. Life Cycle Engineering and Design for Environment of the MB C-Class. 2001. Disponível em: <http://papers.sae.org/2001-01-3730>. Acesso em: 01 jul. 2017.

; et.al. Environmental Certificate of the MB S-Class - Design for Environment and LCA Results. Sindelfingen: Daimler AG, 2006.

FLICK, U. Introdução à pesquisa qualitativa. Porto Alegre: Artmed, 2009.

FLOOD, Robert Louis. The relationship of 'systems thinking' to action research. Systemic Practice and Action Research, New York, v. 23, n. 4, p. 269-284, ago. 2010.

FOLKE, Carl. Resilience: The emergence of a perspective for social-ecological systems analyses. Global Environmental Change, Amsterdam, v. 16, n. 3, p. 253-267, ago. 2006.

FORRESTER, Jay W. System dynamics, systems thinking, and soft OR. System Dynamics Review, Hoboken, v. 10, n. 2-3, p. 245-256, jun. 1994.

FRANCHETTI, S. M. M.; MARCONATO, J. C. A importância das propriedades físicas dos polímeros na reciclagem. Química Nova na Escola, São Paulo, v. 18, p. 42-45, maio 2003.

GABRIEL, L. F. et al. Uma análise da indústria automobilística no Brasil e a demanda de veículos automotores: algumas evidências para o período recente. 2011. Disponível em: $<$ https://www.anpec.org.br/ encontro/2011/inscricao/arquivos/00054d87ea200247ecc320a7f5cc7ca6e2c.pdf>. Acesso em: 05 out. 2016.

GEISSDOERFER, Martin et al. The Circular Economy-A new sustainability paradigm?. Journal of Cleaner Production, Amsterdam, v. 143, p. 757-768, fev. 2017.

GENOVESE, A. et al. Sustainable supply chain management and the transition towards a circular economy: Evidence and some applications. Omega, Oxford, v. 66, p. 344-357, jan. 2017.

GENG, Yong; SARKIS, Joseph; ULGIATI, Sergio. Sustainability, well-being, and the circular economy in China and worldwide. Science, Washington, v. 6278, n. Suppl., p. 73-76, mar. 2016.

GHISELLINI, Patrizia; CIALANI, Catia; ULGIATI, Sergio. A review on circular economy: the expected transition to a balanced interplay of environmental and economic systems. Journal of Cleaner Production, Amsterdam, v. 114, p. 11-32, fev. 2016.

GILJUM, S. et al. Overconsumption? Our use of the world's natural resources. 2009. Disponível em: < https://www.foe.co.uk/sites/default/files/downloads/ overconsumption.pdf $>$. Acesso em: 26 set. 2016. 
GOLINSKA, Paulina; KAWA, Arkadiusz. Remanufacturing in automotive industry: Challenges and limitations. Journal of Industrial Engineering and Management, Barcelona, v. 4, n. 3, p. 453-466, set. 2011.

GROOMBRIDGE, Brian. Global biodiversity: status of the earth's living resources. London: Chapman \& Hall, 1992.

GROSSMANN, I. E. Challenges in the new millennium: product discovery and design, enterprise and supply chain optimization, global life cycle assessment. Computers and Chemical Engineering, Oxford, v. 29, n. 1, p. 29-39, dez. 2004.

GU, P. et al. An integrated modular design methodology for life-cycle engineering. CIRP Annals - Manufacturing Technology, Schönbühl-Urtenen, v. 46, n. 1, p. 71-74, jan. 1997.

GUIDAT, T. et al. Guidelines for the definition of innovative industrial product-service systems (PSS) business models for remanufacturing. Procedia CIRP, Amsterdam, v.16, p. 193-198, jan. 2014.

GUIDE, V. Daniel R. Production planning and control for remanufacturing: industry practice and research needs. Journal of Operations Management, Amsterdam, v. 18, n. 4, p. 467483, jun. 2000.

GWIAZDA, A. Quality tools in a process of technical project management. Journal of Achievements in Materials and Manufacturing Engineering, Gliwice, v. 18, n. 1-2, p. 439-442, set. 2006.

HAAS, W. et al. How circular is the global economy?: an assessment of material flows, waste production, and recycling in the European union and the world in 2005. Journal of Industrial Ecology, Hoboken, v. 19, n. 5, p. 765-777, fev. 2015.

HAMARI, Juho; SJÖKLINT, Mimmi; UKKONEN, Antti. The sharing economy: Why people participate in collaborative consumption. Journal of the Association for Information Science and Technology, Hoboken, v. 67, n. 9, p. 2047-2059, mar. 2015.

HAN, S. et al. Novel anaerobic process for the recovery of methane and compost from food waste. Water Science and Technology, London, v. 45, n. 10, p. 313-319, maio 2002.

HAWKEN, P.; LOVINS, A.; LOVINS, L. H. Natural capitalism: creating the next industrial revolution. New York: Back Bay Books, 2008.

HEINRICHS, Harald. Sharing economy: a potential new pathway to sustainability. Gaia, Munich, v. 22, n. 4, p. 228, maio 2013.

HESHMATI, Almas. A Review of the Circular Economy and its Implementation. 2016. Disponível em: < https://papers.ssrn.com/sol3/papers.cfm?abstract_id=2713032>. Acesso em: 01 nov. 2016.

HINTERBERGER, Friedrich; SCHMIDT-BLEEK, Friedrich. FORUM: Dematerialization, MIPS and Factor 10 Physical sustainability indicators as a social device. Ecological Economics, Amsterdam, v. 29, n. 1, p. 53-56, abr. 1999. 
HOLLING, Crawford S. Resilience and stability of ecological systems. Annual Review of Ecology and Systematics, Palo Alto, v. 4, n. 1, p. 1-23, nov. 1973.

Understanding the complexity of economic, ecological, and social systems.

Ecosystems, Heidelberg, v. 4, n. 5, p. 390-405, ago. 2001.

HOORNWEG, Daniel; BHADA-TATA, Perinaz. What a waste: a global review of solid waste management. The World Bank: Urban development series knowledge papers, Washington, v. 15, p. 1-98, mar. 2012.

HOWER, Mike. 8 companies to watch in the circular economy. 2016. Disponível em: $<$ https://www.greenbiz.com/article/8-companies-watch-circular-economy>. Acesso em: 26 dez. 2016.

IENM. A circular economy in the Netherlands by 2050. 2016. Disponível em: $<$ https://www.oecd.org/environment/ministerial/whatsnew/2016-ENV-MinisterialNetherlands-Circular-economy-in-the-Netherlands-by-2050.pdf>. Acesso em: 08 mar. 2017.

INTERNATIONAL ORGANIZATION FOR STANDARDIZATION (ISO). ISO 14040: Environmental management - Life Cycle Assessment - principles and framework. Geneva: ISO, 1997.

ISO 14062: Environmental management - Integrating environmental aspects into

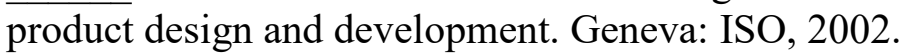

JAWAHIR, I. S.; BRADLEY, Ryan. Technological Elements of Circular Economy and the Principles of 6R-Based Closed-loop Material Flow in Sustainable Manufacturing. Procedia CIRP, Amsterdam, v. 40, p. 103-108, fev. 2016.

JAYARAMAN, V.; GUIDE JR, V. D. R.; SRIVASTAVA, R. A closed-loop logistics model for remanufacturing. Journal of the Operational Research Society, London, v. 50, n. 5, p. 497-508, maio 1999.

KANG, Hai-Yong; SCHOENUNG, Julie M. Electronic waste recycling: A review of US infrastructure and technology options. Resources, Conservation and Recycling, Amsterdam, v. 45 , n. 4 , p. $368-400$, dez. 2005.

KERR, Wendy; RYAN, Chris. Eco-efficiency gains from remanufacturing: A case study of photocopier remanufacturing at Fuji Xerox Australia. Journal of Cleaner Production, Amsterdam, v. 9, n. 1, p. 75-81, fev. 2001.

KIMURA, F. et al. Product modularization for parts reuse in inverse manufacturing. CIRP Annals - Manufacturing Technology, Schönbühl-Urtenen, v. 50, n. 1, p. 89-92, jan. 2001.

KORHONEN, Jouni; WIHERSAARI, Margareta; SAVOLAINEN, Ilkka. Industrial ecosystem in the Finnish forest industry: using the material and energy flow model of a forest ecosystem in a forest industry system. Ecological Economics, Amsterdam, v. 39, n. 1, p. 145161, out. 2001. 
LEISMANN, K. et al. Collaborative consumption: towards a resource-saving consumption culture. Resources, Basel, v. 2, n. 3, p. 184-203, jul. 2013.

LEITÃO, Alexandra. Economia circular: uma nova filosofia de gestão para o séc. XXI.

Portuguese Journal of Finance, Management and Accounting, Santa Maria da Feira, v. 1, n. 2, p. 149-171, set. 2015.

LELLIS FERREIRA, F. D. S.; FARIAS FILHO, J. R.; QUELHAS, O. L. G. Análise dos processos de recuperação das embalagens PET: Uma Contribuição da Logística Reversa. Revista ESPACIOS, Caracas, v. 37, n.18, p.3, mar. 2016.

LESLIE, H. A. et al. Propelling plastics into the circular economy-weeding out the toxics first. Environment International, Oxford, v. 94, p. 230-234, set. 2016.

LEWANDOWSKI, Mateusz. Designing the Business Models for Circular EconomyTowards the Conceptual Framework. Sustainability, Basel, v. 8, n. 1, p. 43, jan. 2016.

LI, X. et al. Utilization of municipal solid waste incineration bottom ash in blended cement. Journal of Cleaner Production, Amsterdam, v. 32, p. 96-100, set. 2012.

LIEDER, Michael; RASHID, Amir. Towards circular economy implementation: a comprehensive review in context of manufacturing industry. Journal of Cleaner Production, Amsterdam, v. 115, p. 36-51, mar. 2016.

LINDER, Marcus; SARASINI, Steven; LOON, Patricia. A Metric for Quantifying ProductLevel Circularity. Journal of Industrial Ecology, Hoboken, v.21, n.3, p. 545-558, fev. 2017.

LIU, S. et al. Valuing New Jersey's ecosystem services and natural capital: a spatially explicit benefit transfer approach. Environmental Management, Heidelberg, v. 45, n. 6, p. 12711285, jun. 2010.

LOMBARDI, D. Rachel; LAYBOURN, Peter. Redefining industrial symbiosis. Journal of Industrial Ecology, Hoboken, v. 16, n. 1, p. 28-37, fev. 2012.

LOZANO, R. et al. Editorial board changes in the Journal of Cleaner Production. Journal of Cleaner Production, Amsterdam, v. 30, p. 1, fev. 2016.

LUND, Robert T. Remanufacturing, United States experience and implications for developing nations. Massachusetts: Massachusetts Institute of Technology, 1983.

LYLE, John Tillman. Regenerative design for sustainable development. New York: John Wiley \& Sons, 1996.

MATHEWS, John A.; TANG, Yiming; TAN, Hao. China's move to a Circular Economy as a development strategy. Asian Business and Management, London, v. 10, n. 4, p. 463-484, nov. 2011.

MATHEWS, J. A.; TAN, H. Progress towards a circular economy in China: The drivers (and inhibitors) of eco-industrial initiative. Journal of Industrial Ecology, Hoboken, v. 15, n. 3, p. 435-457, mar. 2011. 
MB. Releases 2011. 2011. Disponível em: $<$ https://www.mercedes-

benz.com.br/institucional/imprensa/releases/corporativo>. Acesso em: 02 ago. 2017.

Releases 2013. 2013. Disponível em: <https://www.mercedes-

benz.com.br/institucional/imprensa/releases/corporativo>. Acesso em: 26 jul. 2017.

Relatório de Sustentabilidade 2014-2015 - MB. São Bernardo do Campo, ed. 1, 55 p., dez. 2016 a.

Releases 2016. 2016b. Disponível em: $<$ https://www.mercedes-

benz.com.br/institucional/imprensa/releases/corporativo>. Acesso em: 25 jul. 2017.

. Serviços e Peças. 2017a. Disponível em: <https://www.mercedes-

benz.com.br/caminhões/servicos-e-pecas >. Acesso em: 25 jul. 2017.

Releases 2017. 2017b. Disponível em: $<$ https://www.mercedes-

benz.com.br/institucional/imprensa/releases/corporativo>. Acesso em: 25 jul. 2017.

Sustentabilidade. 2017c. Disponível em: <https://www.mercedes-benz.com.br/ institucional/sustentabilidade >. Acesso em: 02 ago. 2017.

Tecnologias. 2017d. Disponível em: $<$ https://www.mercedesbenz.com.br/caminhoes/motores-bluetec/tecnologia>. Acesso em: 02 ago. 2017.

MCDONOUGH, William; BRAUNGART, Michael. The next industrial revolution. The Atlantic Monthly, Boston, v. 282, n. 4, p. 82-92, out. 1998.

Point, 2002.

Cradle to cradle: Remaking the way we make things. New York: North

Towards a sustaining architecture for the 21st century: the promise of cradle-to-cradle design. Industry and Environment, Paris, v. 26, n. 2, p. 13-16, abr/set. 2003.

MEADOWS, Donella H.; MEADOWS, Denis L.; RANDERS, Jorgen. The limits to growth. V.102. New York: Universe Books, 1972.

MEADOWS, Donella H.; WRIGHT, Diana. Thinking in systems: A primer. Vermont: Chelsea Green Publishing, 2008.

MELLINO, S. et al. An emergy-GIS approach to the evaluation of renewable resource flows: a case study of Campania Region, Italy. Ecological Modelling, Amsterdam, v. 271, p. 103112, jan. 2014.

MITCHELL, Peter; JAMES, Keith. Economic Growth Potential of More Circular

Economies. 2015. Disponível em: < http://www.ciwm-journal.co.uk/wordpress/wpcontent/uploads/2015/09/ECONOMIC-GROWTH-POTENTIAL-OF-MORE-CIRCULARECONOMIES-FINAL-v04.09.20151.pdf>. Acesso em: 01 out. 2016. 
MURRAY, Alan; SKENE, Keith; HAYNES, Kathryn. The circular economy: An interdisciplinary exploration of the concept and application in a global context. Journal of Business Ethics, Dordrecht, v. 140, n. 3, p. 369-380, fev. 2017.

MURRAY, Robin. Zero waste. London: Greenpeace Environmental Trust, 2002.

NARODOSLAWSKY, M.; OBERNBERGER, I. From waste to raw material - the route from biomass to wood ash for cadmium and other heavy metals. Journal of Hazardous Materials, Amsterdam, v. 50, n. 2-3, p. 157-168, out. 1996.

NOCI, Giuliano. Supporting decision-making for recycling-based investments. Business Strategy and the Environment, Hoboken, v. 4, n. 2, p. 62-72, abr. 1995.

OLIVEIRA, A. A.; SILVA, J. T. M. A logística reversa no processo de revalorização dos bens manufaturados. REA - Revista Eletrônica de Administração, Franca, v. 4, n. 2, jul/dez. 2011.

OSTROM, Elinor. A general framework for analyzing sustainability of social-ecological systems. Science, Washington, v. 325, n. 5939, p. 419-422, jul. 2009.

O'SULLIVAN, A; SHEFFRIN, S. M. Economics: Principles in Action. New Jersey: Pearson Prentice Hall, Upper Saddle River, 2003.

PAINULY, Jyoti P. Barriers to renewable energy penetration; a framework for analysis. Renewable energy, Oxford, v. 24, n. 1, p. 73-89, set. 2001.

PAULI, Gunter A. The blue economy: 10 years, 100 innovations, 100 million jobs. Taos: Paradigm Publications, 2010.

PEARCE, D. W; TURNER, R. K. Economics of natural resources and the environment. Hemel Hempstead, Herts: Harvester Wheatsheaf, 1990. 392 p.

PEHNT, Martin. Dynamic life cycle assessment (LCA) of renewable energy technologies. Renewable energy, Oxford, v. 31, n. 1, p. 55-71, jan. 2006.

PIGOU, Arthur C. The economics of welfare, 1920. London: McMillan\&Co., 1932.

PORTER, Michael E.; KRAMER, Mark R. Creating shared value: Redefining capitalism and the role of the corporation in society. Harvard Business Review, Boston, v. 89, n. 1/2, p. 6277, jul. 2011.

PRESTON, Felix. A global redesign? shaping the circular economy. Energy, Environment and Resource Governance, London, v. 2, p. 1-20, mar. 2012.

QUINTELLA, Heitor Luiz Murat de Meirelles; ROCHA, Henrique Martins; ALVES, Manuela Fontana. Automobile Project management: Critical success factors in product startup. Production, São Paulo, v. 15, n. 3, p. 334-346, set/dez. 2005.

QUIVY, R.; CAMPENHOUDT, L. V. Manual de investigação em ciências sociais. 5. ed. Lisboa: Gradiva Publicações SA, 2008. 
REDFIELD, Alfred C. The biological control of chemical factors in the environment. American Scientist, North Carolina, v. 46, n. 3, p. 205-221, set. 1958.

RENOVA ECOPEÇAS. Releases 2015: Renova Ecopeças faz reciclagem dos veículos irrecuperáveis da Porto Seguro. 2015. Disponível em:

$<$ http://institucional.renovaecopecas.com.br/noticias/renova-ecopeas-faz-reciclagem-dosveculos-irrecuperveis-da-porto-seguro-07-12> Acesso em: 14 set. 2017.

REZZADORI, K.; BENEDETTI, S.; AMANTE, E. R. Proposals for the residues recovery: orange waste as raw material for new products. Food and Bioproducts Processing, Rugby, v. 90, n. 4, p. 606-614, out. 2012.

SAUVÉ, Sébastien; BERNARD, Sophie; SLOAN, Pamela.Environmental sciences, sustainable development and circular economy: Alternative concepts for trans-disciplinary research. Environmental Development, Amsterdam, v. 17, p. 48-56, jan. 2016.

SAVASKAN, R. Canan; BHATTACHARYA, Shantanu; VAN WASSENHOVE, Luk N. Closed-loop supply chain models with product remanufacturing. Management science, Catonsville, v. 50, n. 2, p. 239-252, fev. 2004.

SCHEER, Roddy; MOSS, Doug. Use It and Lose It: The Outsize Effect of US Consumption on the Environment. 2012. Disponível em: $<$ https://www.scientificamerican.com/article/ american-consumption-habits/>. Acesso em: 01 fev. 2017.

SELECTRUCKS. Sobre a SelecTrucks. 2017. Disponível em:

$<$ http://www.selectrucks.com.br/sobre>. Acesso em: 25 jul. 2017.

SHAHBAZI, S. et al. Material efficiency in manufacturing: swedish evidence on potential, barriers and strategies. Journal of Cleaner Production, Amsterdam, v. 127, p. 438-450, jul. 2016.

SHARMA, P. et al. Automobile Waste and Its Management. Research Journal of Chemical and Environmental Sciences, Agra, v.4, n.2, p.1-7, abr. 2016.

SHARP, Lucy. Driving environmental research transformation through financial markets. Impact, Bristol, v. 2016, n. 1, p. 10-11, jun. 2016.

SOO, Vi Kie; COMPSTON, Paul; DOOLAN, Matthew. Is the Australian Automotive Recycling Industry Heading towards a Global Circular Economy?-A Case Study on Vehicle Doors. Procedia CIRP, Amsterdam, v. 48, p. 10-15, mar. 2016.

STAHEL, W. R. The Performance Economy. London: Palgrave Macmillan, 2006.

STAHEL, W. R.; REDAY-MULVEY, Genevieve. Jobs for tomorrow: the potential for substituting manpower for energy. New York: Vantage Press, 1981.

$\mathrm{SU}$, B. et al. A review of the circular economy in China: moving from rhetoric to implementation. Journal of Cleaner Production, Amsterdam, v. 42, p. 215-227, mar. 2013. 
TENNENBAUM, Carla. Isso não é: Camisetas de PET + algodão. 2015. Disponível em: $<$ http://www.ideiacircular.com/single-post/2015/11/03/Isso-não-é-Camisetas-de-PETalgodão>. Acesso em: 04 fev. 2017.

THORMARK, Catarina. A low energy building in a life cycle - its embodied energy, energy need for operation and recycling potential. Building and Environment, Oxford, v. 37, n. 4, p. 429-435, abr. 2002.

TONGLET, Michele; PHILLIPS, Paul S.; BATES, Margaret P. Determining the drivers for householder pro-environmental behaviour: waste minimisation compared to recycling.

Resources, Conservation and Recycling, Amsterdam, v. 42, n. 1, p. 27-48, ago. 2004.

TURNER, R. K.; DAILY, G. C. The ecosystem services framework and natural capital conservation. Environmental and Resource Economics, Dordrecht, v. 39, n. 1, p. 25-35, jan. 2008.

VAN DE WIEL, Han. The Netherlands as materials roundabout. 2011. Disponível em: $<$ http://www.wastematters.eu/uploads/media/ The_Netherlands_as_materials_roundabout. pdf $>$. Acesso em: 01 fev. 2017.

VAN DEN BERGH, Jeroen C. Ecological economics: themes, approaches, and differences with environmental economics. Regional Environmental Change, Berlin, v. 2, n. 1, p. 1323, ago. 2001.

VAZ, Caroline Rodrigues; LEZANA, Alvaro Guillermo Rojas; MALDONADO, Mauricio Uriona. Sustainability in the automotive sector: An analysis of structured content. Journal on Innovation and Sustainability, São Paulo, v. 8, n. 2, p. 79-103, jun/ago. 2017.

VEIGA, Lilian Bechara Elabras; MAGRINI, Alessandra. Eco-industrial park development in Rio de Janeiro, Brazil: a tool for sustainable development. Journal of Cleaner Production, Amsterdam, v. 17, n. 7, p. 653-661, mai. 2009.

VILLALBA, G. et al. Using the recyclability index of materials as a tool for design for disassembly. Ecological Economics, Amsterdam, v. 50, n. 3, p. 195-200, out. 2004.

VITOUSEK, P. M. et al. Human domination of Earth's ecosystems. Science, Washington, v. 277, n. 5325, p. 494-499, jul. 1997.

VOORTHUIS, Jacob; GIJBELS, Cyrille. A Fair Accord: Cradle to Cradle as a Design Theory Measured against John Rawls' Theory of Justice and Immanuel Kant's Categorical Imperative. Sustainability, Basel, v. 2, n. 1, p. 371-382, jan. 2010.

WACKERNAGEL, Mathis; REES, William E. Perceptual and structural barriers to investing in natural capital: Economics from an ecological footprint perspective. Ecological Economics, Amsterdam, v. 20, n. 1, p. 3-24, jan. 1997

WALKER, Brian. et al. Resilience, adaptability and transformability in social-ecological systems. Ecology and Society, [S.L], v. 9, n. 2, set. 2004. 
WANKE, Peter; FLEURY, Paulo Fernando. Transporte de cargas no Brasil: estudo exploratório das principais variáveis relacionadas aos diferentes modais e às suas estruturas de custos. Brasília: Instituto de Pesquisa Econômica Aplicada, 2006.

WILLIAMS, E. et al. Environmental, social, and economic implications of global reuse and recycling of personal computers. Environmental Science \& Technology, Washington, v. 42, n. 17, p. 6446-6454, abr. 2008.

YANG, Shanlin; FENG, Nanping. A case study of industrial symbiosis: Nanning Sugar Co., Ltd. in China. Resources, Conservation and Recycling, Amsterdam, v. 52, n. 5, p. 813-820, mar. 2008.

YIN, R. K. Estudo de Caso - Planejamento e Métodos. 5. ed. Porto Alegre: Bookman, 2015.

YOUNG, O. R. et al. The globalization of socio-ecological systems: an agenda for scientific research. Global Environmental Change, Amsterdam, v. 16, n. 3, p. 304-316, ago. 2006.

YUAN, Zengwei; BI, Jun; MORIGUICHI, Yuichi. The circular economy: A new development strategy in China. Journal of Industrial Ecology, Hoboken, v. 10, n. 1-2, p. 48 , jan. 2006.

ZHANG, T. et al. Development pattern and enhancing system of automotive components remanufacturing industry in China. Resources, Conservation and Recycling, Amsterdam, v. 55, n. 6, p. 613-622, abr. 2011.

ZHANG, Ji-Hao; CHEN, Ming. Assessing the impact of China's vehicle emission standards on diesel engine remanufacturing. Journal of Cleaner Production, Amsterdam, v. 107, p. 177-184, nov. 2015.

ZHU, Qinghua et al. A comparison of regulatory awareness and green supply chain management practices among Chinese and Japanese manufacturers. Business Strategy and the Environment, Hoboken, v. 26, n. 1, p. 18-30, jan. 2017. 
APÊNDICE A - Guia para entrevistas 


\section{Guia para entrevistas}

\begin{tabular}{|l|l|}
\hline \multicolumn{2}{|c|}{ Etapas da entrevista } \\
\hline 1 & Apresentação do projeto de pesquisa e do mestrando \\
\hline 2 & Agradecimento da disponibilidade para a entrevista e visita de campo \\
\hline 3 & $\begin{array}{l}\text { Explicar que a pesquisa possui cunho acadêmico e que servirá de base para desenvolvimento de } \\
\text { dissertação sobre Economia Circular. }\end{array}$ \\
\hline 4 & $\begin{array}{l}\text { Explicar que as respostas das empresas serão tabuladas em conjunto não havendo possibilidade de } \\
\text { identificação única }\end{array}$ \\
\hline 5 & Explicar a questão sigilo da pesquisa quanto à identidade dos entrevistados. \\
\hline 6 & Explicar as etapas da pesquisa: transcrição, aprovação e tabulação dos dados coletados. \\
\hline 7 & Detalhamento dos objetivos da entrevista \\
\hline 8 & Inicio do questionário (não interromper o entrevistado). \\
\hline 9 & $\begin{array}{l}\text { Finalização do questionário (informe de que após a transcrição o documento será enviado para } \\
\text { validação) }\end{array}$ \\
\hline 10 & $\begin{array}{l}\text { Questionamento sobre se o entrevistado se colocaria a disposição para uma entrevista adicional, se } \\
\text { necessário. }\end{array}$ \\
\hline 11 & Agradecimento da disponibilidade e das informações \\
\hline
\end{tabular}


APÊNDICE B - Indicadores e questões da entrevista semiestruturada 


\section{Indicadores e questões da entrevista semiestruturada}

\begin{tabular}{|c|c|c|c|c|}
\hline Uू. & 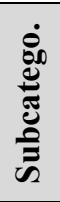 & 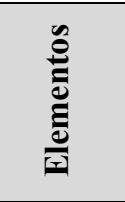 & Indicadores & Questões da entrevista semiestruturada \\
\hline \multirow{4}{*}{ 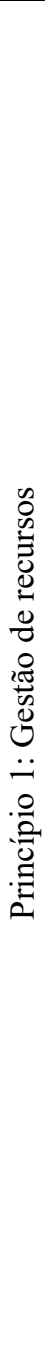 } & $\begin{array}{l}0 \\
0 \\
0 \\
0 \\
0 \\
0 \\
0 \\
0 \\
0 \\
0 \\
0 \\
0 \\
0 \\
0 \\
0 \\
0 \\
0 \\
0 \\
0 \\
0 \\
0 \\
0\end{array}$ & 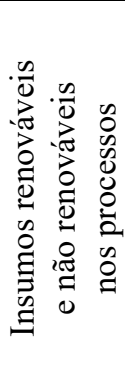 & $\begin{array}{l}\text { Consumo de água; } \\
\text { - Consumo de Gás } \\
\text { Liquefeito de Petróleo; } \\
\text { - Consumo de Gás Natural; } \\
\text { - Consumo de eletricidade; } \\
\text { - Consumo de embalagens; } \\
\text { - Outros consumos; } \\
\text { - Uso de energias } \\
\text { alternativas nos processos. }\end{array}$ & $\begin{array}{l}\text { Quais os indicadores ambientais monitorados nos processos? } \\
\text { - Como está o desempenho dos indicadores? } \\
\text { - Existem fontes alternativas de energia em uso nos processos? } \\
\text { Se sim, quais são? } \\
\text { - Quais as práticas para melhorar continuamente o desempenho } \\
\text { ambiental dos processos? } \\
\text { - Sobre o consumo de insumos e o desempenho dos processos, } \\
\text { há outros aspectos que você gostaria de destacar? }\end{array}$ \\
\hline & \multirow{3}{*}{ 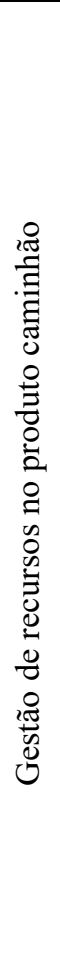 } & 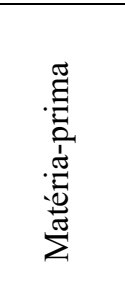 & $\begin{array}{l}\text { - Tipos de materiais } \\
\text { predominantes; } \\
\text { - Uso de materiais } \\
\text { recicláveis; } \\
\text { - Uso de materiais } \\
\text { reciclados. }\end{array}$ & $\begin{array}{l}\text { Quais os tipos de materiais predominantes no caminhão? } \\
\text { - São consideradas questões ambientais ao estabelecer quais } \\
\text { materiais serão utilizados no caminhão? } \\
\text { - São utilizados materiais alternativos em sua composição? } \\
\text { - Existem projetos para uso de materiais alternativos? } \\
\text { - Sobre a composição do caminhão, há outros aspectos que } \\
\text { você gostaria de destacar? }\end{array}$ \\
\hline & & 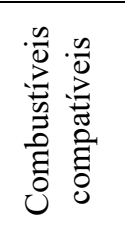 & $\begin{array}{l}\text { Tipos de combustíveis que } \\
\text { podem ser utilizados no } \\
\text { produto; } \\
\text { - Uso de combustíveis } \\
\text { alternativos para o produto. }\end{array}$ & $\begin{array}{l}\text { - Quais são os combustíveis que o caminhão pode utilizar? } \\
\text { - Há combustíveis alternativos? } \\
\text { - Existem projetos para o uso de combustíveis alternativos? } \\
\text { - Sobre os combustíveis utilizados no caminhão, há outros } \\
\text { aspectos que você gostaria de destacar? }\end{array}$ \\
\hline & & 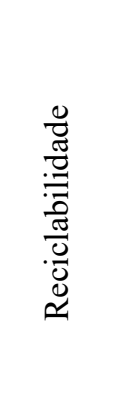 & $\begin{array}{l}\text { - Uso de peças recicláveis } \\
\text { no produto; } \\
\text { - Uso de peças recicladas no } \\
\text { produto. }\end{array}$ & $\begin{array}{l}\text { - São utilizadas peças recicláveis no caminhão? } \\
\text { - Qual o índice de reciclabilidade do caminhão em percentual? } \\
\text { - O que impulsionou o uso de peças recicláveis? } \\
\text { - Quais os tipos de reciclagem praticadas nas peças do } \\
\text { caminhão? } \\
\text { - São utilizadas peças recicladas no caminhão? } \\
\text { - Há algum índice de uso de peças recicladas no caminhão? } \\
\text { - O que impulsionou o uso de peças recicladas? } \\
\text { - Sobre a reciclabilidade e uso de peças recicladas no caminhão } \\
\text { hautros aspectos que você gostaria de destacar? }\end{array}$ \\
\hline
\end{tabular}


Conclusão

\begin{tabular}{|c|c|c|c|c|}
\hline & & 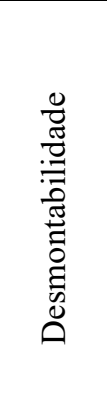 & $\begin{array}{l}\text { - Desmontabilidade de } \\
\text { peças e componentes no } \\
\text { produto. }\end{array}$ & $\begin{array}{l}\text { - A desmontabilidade de peças e componentes é considerada no } \\
\text { design do caminhão? } \\
\text { - Há algum índice de desmontabilidade de peças e componentes } \\
\text { no caminhão? } \\
\text { - Existem projetos para aumentar a desmontabilidade de peças e } \\
\text { componentes do caminhão? } \\
\text { - Quais os benefícios e os limites do aumento da } \\
\text { desmontabilidade? } \\
\text { - Sobre a desmontabilidade de peças e componentes do } \\
\text { caminhão, há outros aspectos que você gostaria de destacar? }\end{array}$ \\
\hline & & 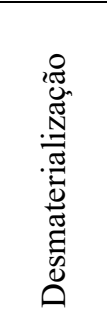 & $\begin{array}{l}\text { Peso do produto; } \\
\text { - Quantidade de materiais } \\
\text { utilizados no produto. }\end{array}$ & $\begin{array}{l}\text { O peso do produto tem reduzido com a evolução do design do } \\
\text { caminhão? } \\
\text { - Existe algum indicador que demonstre a redução do peso? } \\
\text { - Quais os motivos que a companhia busca a redução do peso? } \\
\text { - A quantidade de materiais utilizados (variedade) reduziu junto } \\
\text { com os novos designs do caminhão? } \\
\text { - Sobre o peso do produto e quantidade de materiais, há outros } \\
\text { aspectos que você gostaria de destacar? }\end{array}$ \\
\hline & & 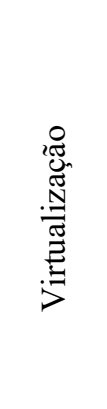 & $\begin{array}{l}\text { - Uso de materiais físicos } \\
\text { para a comercialização de } \\
\text { peças; } \\
\text { - Recursos necessários para } \\
\text { a virtualização da } \\
\text { comercialização de peças. }\end{array}$ & $\begin{array}{l}\text { - O que impulsionou a criação de uma loja virtual de peças? } \\
\text { - Quais os recursos necessários para a operacionalização da loja } \\
\text { virtual de peças? } \\
\text { - Como os clientes buscam as peças? } \\
\text { - Existe alguma estimativa de redução de uso de materiais } \\
\text { físicos em razão da loja virtual? } \\
\text { - Existe alguma estimativa de redução de uso de espaço físico } \\
\text { em razão da loja virtual de peças? } \\
\text { - Sobre a loja virtual de peças, há outros aspectos que você } \\
\text { gostaria de destacar? }\end{array}$ \\
\hline 总 & $\begin{array}{l}0 \\
0 \\
0 \\
0 \\
0 \\
0 \\
0 \\
0\end{array}$ & 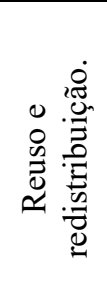 & $\begin{array}{l}\text { - Reutilização de materiais } \\
\text { nos processos; } \\
\text { - Redistribuição dos } \\
\text { materiais reutilizados nos } \\
\text { processos. }\end{array}$ & $\begin{array}{l}\text { Os materiais são reutilizados dentro dos processos? } \\
\text { - Os materiais são reutilizados em outros processos? } \\
\text { - Como é feita a redistribuição dos materiais a serem } \\
\text { reutilizados nos processos (logística)? } \\
\text { - Qual a redução de descarte devido reuso de materiais? } \\
\text { - Sobre o reuso nos processos, há outros aspectos que você } \\
\text { gostaria de destacar? }\end{array}$ \\
\hline 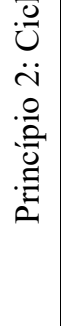 & 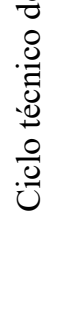 & 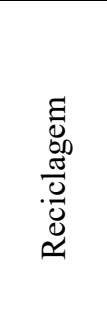 & $\begin{array}{l}\text { - Reciclagem de resíduos } \\
\text { provenientes de insumos } \\
\text { dos processos. }\end{array}$ & $\begin{array}{l}\text { Quais os resíduos gerados do processo que podem ser } \\
\text { reciclados? } \\
\text { - Qual o índice de reciclagem de resíduos em relação ao volume } \\
\text { total gerado nos processos? } \\
\text { - Quais os tipos de reciclagem aplicados aos resíduos do } \\
\text { processo (transformação em energia, em novos produtos, etc)? } \\
\text { - Sobre o a reciclagem de insumos nos processos, há outros } \\
\text { aspectos que você gostaria de destacar? }\end{array}$ \\
\hline
\end{tabular}

Continua 
Conclusão

\begin{tabular}{|c|c|c|c|}
\hline \multirow{4}{*}{ 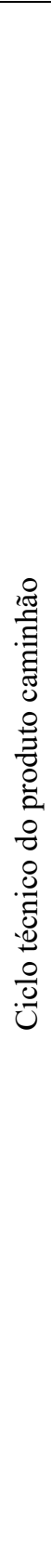 } & 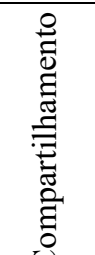 & $\begin{array}{l}\text { - Compartilhamento de peças } \\
\text { e componentes; } \\
\text { - Compartilhamento do } \\
\text { caminhão. }\end{array}$ & $\begin{array}{l}\text { Existem iniciativas de compartilhamentos de peças, } \\
\text { componentes? } \\
\text { - Existem iniciativas de compartilhamento do caminhão, como } \\
\text { leasing, locação ou arrendamento? } \\
\text { - Sobre o compartilhamento, há outros aspectos que você } \\
\text { gostaria de destacar? }\end{array}$ \\
\hline & 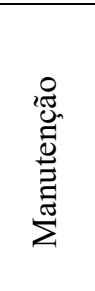 & $\begin{array}{l}\text { - Extensão da vida do produto } \\
\text { com a manutenção } \\
\text { preventiva; }\end{array}$ & $\begin{array}{l}\text { Quais os incentivos ao cliente para a realização de } \\
\text { manutenções preventivas? } \\
\text { - Onde são realizadas as manutenções? } \\
\text { - Existe alguma estimativa de aumento no tempo de vida em } \\
\text { virtude da manutenção preventiva? } \\
\text { - Sobre as atividades de manutenção, há outros aspectos que } \\
\text { você gostaria de destacar? }\end{array}$ \\
\hline & 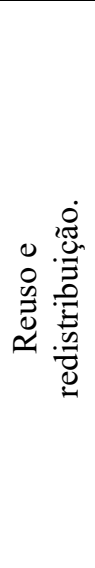 & $\begin{array}{l}\text { - Reutilização de peças e } \\
\text { componentes do caminhão; } \\
\text { - Redistribuição das peças, } \\
\text { componentes e produtos } \\
\text { reutilizados. }\end{array}$ & $\begin{array}{l}\text { Existe reutilização de peças ou componentes em } \\
\text { concessionárias? } \\
\text { Existe reutilização de peças ou componentes na } \\
\text { SelectTrucks? } \\
\text { - Existe reutilização de peças ou componentes na Renov } \\
\text { (remanuatura)? } \\
\text { - Houve redução de descartes devido o reuso de peças ou } \\
\text { componentes? } \\
\text { - Como é feita a redistribuição de peças e componentes } \\
\text { reutilizados? } \\
\text { Quais os reparos realizados no produto para sua revenda na } \\
\text { SelectTrucks? } \\
\text { - Sobre as atividades de reuso e redistribuição, há outros } \\
\text { aspectos que você gostaria de destacar? }\end{array}$ \\
\hline & 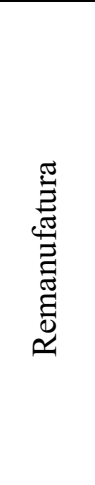 & $\begin{array}{l}\text { - Quantidade de peças no } \\
\text { produto que são } \\
\text { remanufaturadas; } \\
\text { - Extensão da vida do produto } \\
\text { com a remanufatura. }\end{array}$ & $\begin{array}{l}\text { Quais os incentivos ao cliente para a prática da remanufatura? } \\
\text { - Como é realizada a logística dos produtos do cliente até a } \\
\text { planta onde ocorre a remanufatura? } \\
\text { - Atualmente, quais peças ou componentes podem ser } \\
\text { remanufaturados? } \\
\text { - Quais os controles ambientais ao realizar a remanufatura? } \\
\text { - Existe alguma estimativa de extenção de vida do caminhão } \\
\text { devido remanufatura? } \\
\text { - O que é feito com as peças e componentes não } \\
\text { remanufaturáveis? } \\
\text { Sobre a remanufatura, há outros aspectos que você gostaria } \\
\text { de destacar? }\end{array}$ \\
\hline
\end{tabular}


Conclusão

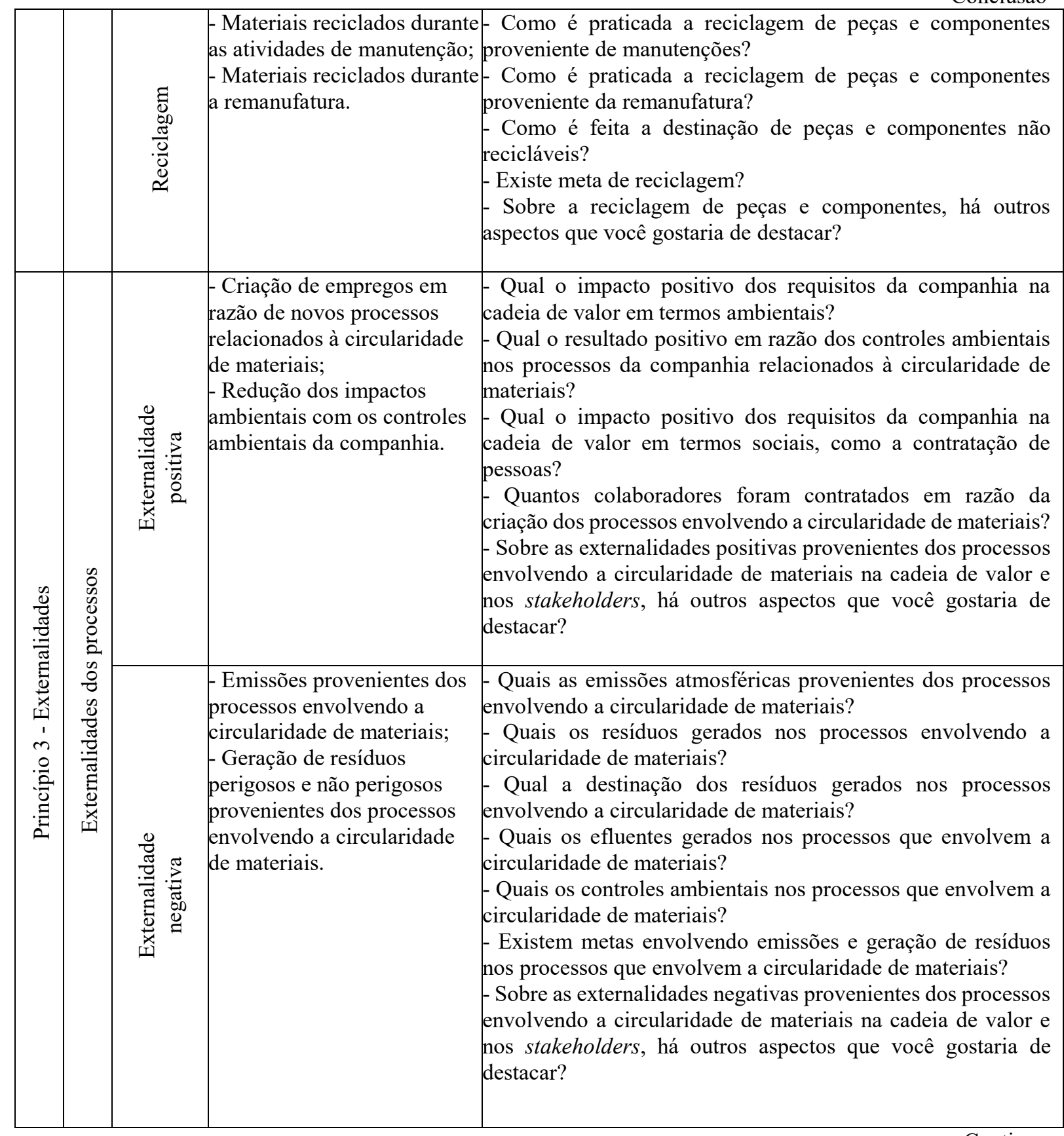

Continua 
Conclusão

\begin{tabular}{|c|c|c|c|}
\hline 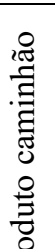 & 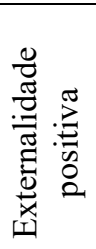 & $\begin{array}{l}\text { Externalidades positivas } \\
\text { com a aplicação da } \\
\text { circularidade dos materiais, } \\
\text { componentes ou produtos. }\end{array}$ & $\begin{array}{l}\text { Quais os benefícios na cadeia de valor e em stakeholders } \\
\text { provenientes da circularidade de materiais, componentes ou } \\
\text { produtos? } \\
\text { - Sobre as externalidades positivas relacionadas aos produtos, } \\
\text { componentes e peças, há outros aspectos que você gostaria de } \\
\text { destacas? }\end{array}$ \\
\hline 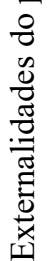 & 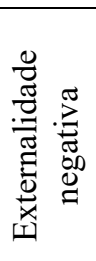 & $\begin{array}{l}\text { Externalidades negativas } \\
\text { com a aplicação da } \\
\text { circularidade dos materiais, } \\
\text { componentes ou produtos. }\end{array}$ & $\begin{array}{l}\text { - Quais as externalidades negativas na cadeia de valor e em } \\
\text { stakeholders com a circularidade de peças, componentes e } \\
\text { caminhões? } \\
\text { - Sobre as externalidades negativas relacionadas aos produtos, } \\
\text { componentes e peças, há outros aspectos que você gostaria de } \\
\text { destacas? }\end{array}$ \\
\hline
\end{tabular}


APÊNDICE C - Protocolo de observação 


\section{Protocolo de observação}

\begin{tabular}{|c|c|}
\hline Local & Elementos observáveis \\
\hline \multirow{4}{*}{ Desenvolvimento } & Requisitos do produto \\
\hline & Descritivo técnico do produto \\
\hline & Composição do produto \\
\hline & $\begin{array}{l}\text { Indicadores: peso, reciclabilidade, } \% \text { materiais } \\
\text { reciclados. }\end{array}$ \\
\hline \multirow{4}{*}{ Programa ServicePlus } & Manual Programa ServicePlus \\
\hline & Locais de Manutenção (controles operacionais) \\
\hline & $\begin{array}{l}\text { Indicadores Manutenção Preventiva x Manutenção } \\
\text { Corretiva }\end{array}$ \\
\hline & Relatórios com resultados em termos ambientais \\
\hline \multirow{2}{*}{ Programa Service $24 \mathrm{~h}$} & Manual Programa Service24h \\
\hline & Relatórios com resultados em termos ambientais \\
\hline \multirow{4}{*}{ Loja Virtual de Peças } & Descritivo do processo \\
\hline & $\begin{array}{l}\text { Lista de lojas físicas antes da loja virtual e perfil das } \\
\text { lojas }\end{array}$ \\
\hline & Lista de lojas físicas após loja virtual e perfil das lojas \\
\hline & Relatórios com resultados em termos ambientais \\
\hline \multirow{10}{*}{ Remanufatura } & Descritivo do processo \\
\hline & Câmbios e motores antes da remanufatura \\
\hline & Levantamento de aspectos e impactos ambientais \\
\hline & Controles operacionais dos processos \\
\hline & Indicadores ambientais de consumo de insumos \\
\hline & Indicadores ambientais de consumo de matérias-primas \\
\hline & Indicadores ambientais de geração de resíduos \\
\hline & Resíduos gerados nos processos \\
\hline & Câmbios e motores após a remanufatura \\
\hline & Relatórios com resultados em termos ambientais \\
\hline \multirow[b]{2}{*}{ SelecTrucks } & Manual do cliente SelecTrucks \\
\hline & $\begin{array}{l}\text { Descritivo e fluxo do processo (chegada do caminhão, } \\
\text { manutenções e disponibilização para venda) }\end{array}$ \\
\hline
\end{tabular}


Conclusão

\begin{tabular}{|l|l|}
\hline \multirow{1}{*}{} & Controles operacionais dos processos \\
\cline { 2 - 2 } & Indicadores ambientais de consumo de insumos \\
\cline { 2 - 2 } & Indicadores ambientais de consumo de matérias-primas \\
\cline { 2 - 2 } & Indicadores ambientais de geração de resíduos \\
\cline { 2 - 2 } & Resíduos gerados nos processos \\
\cline { 2 - 2 } & Relatórios com resultados em termos ambientais \\
\hline
\end{tabular}

